\title{
São Paulo. Uma linha do tempo através do arquiteto Geraldo Vespaziano Puntoni.
}

Sebastian Friedrich Beck

Dissertação apresentada ao programa de pós-graduação da Faculdade de

Arquitetura e Urbanismo da Universidade de São Paulo

Área de Concentração Projeto de Arquitetura

Orientação

Profa. Dra. Anália Maria Marinho de Carvalho Amorim

Universidade de São Paulo - Faculdade de Arquitetura e Urbanismo

São Paulo, Março de 2017 
Autorizo a reprodução e divulgação total ou parcial deste trabalho, por qualquer meio convencional ou eletrônico, para fins de estudo e pesquisa, desde que citada a fonte.

E-mail: info@sebastian-beck.com

Catalogação na Publicação

Serviço Técnico de Biblioteca

Faculdade de Arquitetura e Urbanismo da Universidade de São Paulo

Beck, Sebastian Friedrich
São paulo. uma linha do tempo através do
393s
arquiteto geraldo vespaziano puntoni / Sebastian
Friedrich Beck, orientadora Anália Maria Marinho de
Carvalho Amorim. - São Paulo, 2017.
245p.
Dissertacaão (Mestrado) - Faculdade de Arquitetura
e Urbanismo da Universidade de São Paulo. Arrea de
concentração: Projeto da Arquitetura
1. Servidor Público. 2. Obras Públicas. 3. Órgãos
Públicos. 4. Arquiteto. 5. Linha do Tempo. I.
Amorim, Anália Maria Marinho de Carvalho, orient.
II. Título.


Nome: Sebastian Friedrich Beck

Título: São Paulo. Uma linha do tempo através do arquiteto Geraldo Vespaziano Puntoni

Área: Projeto de Arquitetura

Dissertação apresentada ao programa de pós-graduação da Faculdade de

Arquitetura e Urbanismo da Universidade de São Paulo para obtenção do título de Mestre

Aprovado em:

Banca Examinadora

Prof. Dr.

Instituição

Julgamento: Assinatura

Prof. Dr.

Instituição:

Julgamento: Assinatura

Prof. Dr. Instituição:

Julgamento: Assinatura 



\section{AGRADECIMENTOS}

a Coordenação de Aperfeiçoamento de Pessoal

de Nível Superior (CAPES) pelo apoio à pesquisa

à Anália Maria Marinho de Carvalho Amorim, pela amizade, orientação e dedicação

a Helena Aparecida Ayoub Silva e Luis Octávio Pereira Lopes Faria e Silva pela contribuição nos exames e pelos conselhos precisos

aos professores Julio Katinsky, Rafael Perrone, Marta Vieira Bogéa, Francisco Spadoni, Daniele Pisani

aos meus mestres

Myriam Gautschi e Ciro Pirondi

a Eduardo Ferroni, José Paulo Gouvêa, Maira Rios, Alvaro Puntoni, Herman Tartsch, Carlos Palladini aos funcionários da Biblioteca da FAUUSP e da

Biblioteca da FAU Maranhão

aos entrevistados, pela memória

Clementina Delfina de Ambrosis

Domingos Teodoro de Azevedo Marques

Sílvio Breno de Souza Santos

Marlene Picarelli

Lucio Grinover

Maria Giselda Visconti

Bolivar Pereira da Silva

a Marília De Azevedo Correa

pela amizade e colaboração a Geraldo Vespaziano Puntoni

pela amizade e pelas conversas longas

à Aline Beck, a companheira 


\section{RESUMO}

Esta pesquisa é uma sistematização da carreira do arquiteto e funcionário público Geraldo Vespaziano Puntoni, tendo como pano de fundo sua atuação como funcionário do Estado no Departamento de Obras Públicas (DOP), no qual trabalhou de 1960 a 1990. Além do DOP, o arquiteto foi comissionado para cinco outros órgãos e companhias públicas, FECE Fundo Estadual de Construções Escolares, CECAP - Companhia Estadual de Casas para o Povo, CESP - Centrais Eléctricas de São Paulo, EMURB - Empresa Municipal de Urbanização, e IPESP - Instituto de Previdência do Estado de São Paulo onde foram possíveis diversas experiências e expressões arquitetônicas e urbanas.

A partir da pergunta: Qual é a função do arquiteto na construção do país, do estado e da cidade, escolhi um profissional que, de seus sessenta anos de trabalho, dedicou metade à elaboração de projetos e obras em órgãos públicos do esta- do de São Paulo. Esta pesquisa retrata o trajeto deste homem e profissional público. A ideia é avançar na compreensão das políticas públicas urbanas desta época e investigar o quanto destas posturas influenciaram e foram influenciadas pelo arquiteto Geraldo Vespaziano Puntoni.

O objetivo deste trabalho é estudar a história desses órgãos e relacionar a trajetória do arquiteto Geraldo Vespaziano Puntoni com os aspectos mais relevantes da cultura e do imaginário moderno em São Paulo. O levantamento, a organização e a restituição de sua obra, característica da arquitetura brasileira contemporânea, tem como intuito contribuir para o avanço na reflexão acerca da profissão e do seu papel na constituição do espaço urbano nas décadas em questão.
PALAVRAS-CHAVE: 1. Servidor Público. 2. Obras Públicas. 3. Órgãos Públicos. 4. Arquiteto. 5. Linha do Tempo. 


\section{ABSTRACT}

This research is a systematization of Geraldo Vespaziano Puntoni's carrier as an architect and public servant, having as a background his work on the Department of Public Building (DOP), where he stayed from 1960 to 1990 . Beyond DOP, the architect was commissioned to work in five others institutions and companies: Educational Buildings State Fund (FECE), State Company of Houses for the People (CECAP), São Paulo Electrical Centers (CESP) and Municipal Company of Urbanization (EMURB) and Welfare Institute of São Paulo (IPESP). During his stay at those institutions, the architect had several experiences and was able to try many different architectural and urban expressions.

Starting with the question "What is the architect's role in the development of a country, state and city?", I chose a professional that dedicated half of his 60 years of work to the elaboration of projects for public institutions in São Paulo.
This research shows the story of a man and public servant. The idea behind it is to explore the realm of public politics of the studied period and investigate just how much of this scenario influenced and have been influenced by the architect Geraldo Vespaziano Puntoni.

The main objective of this work is to study the story behind those institutions and relate it to the architect's story, along with the most important aspects of the culture and modern imaginary of São Paulo. The gathering of data, organization and restitution of the architect's work, known for being embedded with characteristics of modern Brazilian architecture, helps to enrich the discussion about the role of the professional and its relation to the development of the urban space in the studied decades.
KEYWORDS: 1. Public Servant. 2. Public Buildings. 3. Public Agencies. 4. Architect. 5. Time-line. 



\section{SUMÁRIO}

INTRODUÇÃO

01

DOP - DEPARTAMENTO DE OBRAS PÚBLICAS DO ESTADO DE SÃO PAULO

02

FECE - FUNDO ESTADUAL DE CONSTRUÇÕES ESCOLARES

03 CECAP - CAIXA ESTADUAL DE CASAS PARA O POVO

04 CESP - CENTRAIS ELÉTRICAS DE SÃO PAULO

145

[O ARQUITETO \& O PAÍS]

05 EMURB - EMPRESA MUNICIPAL DE URBANIZAÇÃO

171

[O ARQUITETO \& A CIDADE]

CONSIDERAÇÕES FINAIS

201

[O ARQUITETO \& O MUNDO]

ANEXOS

209

[ENTREVISTAS] 


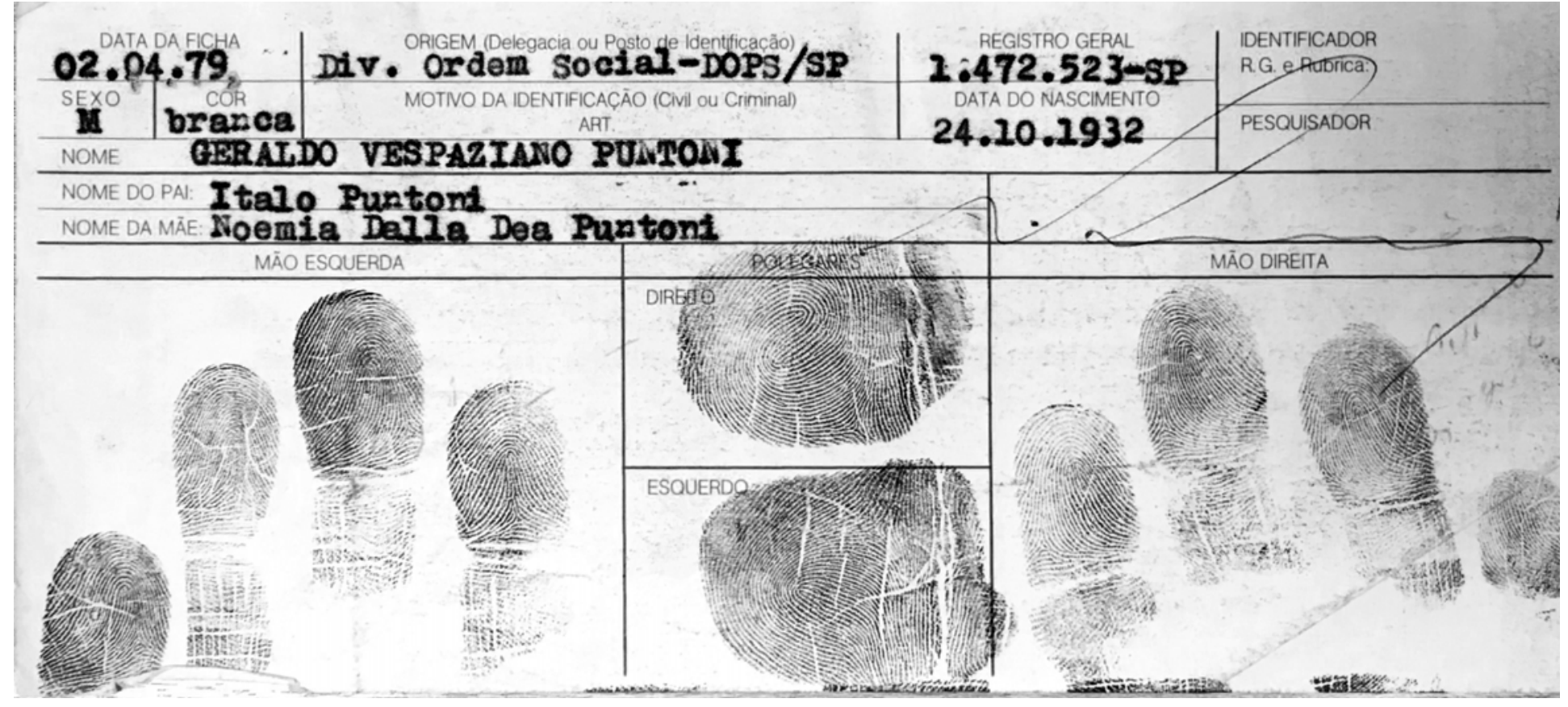

IMAGEM 1. Ficha DOPS, Impressões Digitais, Geraldo Vespaziano Puntoni, 02/04/1979, Fonte: Arquivo Público do Estado São Paulo 
»Os antropólogos explicam que o homem não se adapta o ambiente a si; por isso a sua existência na terra não deixa marcas casuais, mas signos que têm valor de mensagens e com os quais podemos começar a reconstruir a sua história. São documentos por meio dos quais se recorda e se é recordado: e não são apenas as narrativas escritas e as memórias transmitidas, mas também os cantos, as imagens traçadas ou plasmadas, os vestígios de estabelecimentos, os restos das construções, as armas, os utensílios, tudo. Não há documento que não seja o produto de um projeto e de uma operação técnica; e o documento é sempre um objeto, ainda que se trate de um conto, uma poesia, um canto. A constituição de uma coisa qualquer pressupõe uma dupla perspectiva temporal, sobre o passado e sobre o futuro. O primeiro homem que fabricou um copo para beber e, depois de ter bebido, guardou-o para se servir dele. Sobre uma experiência passada construiu um projeto para o futuro." 


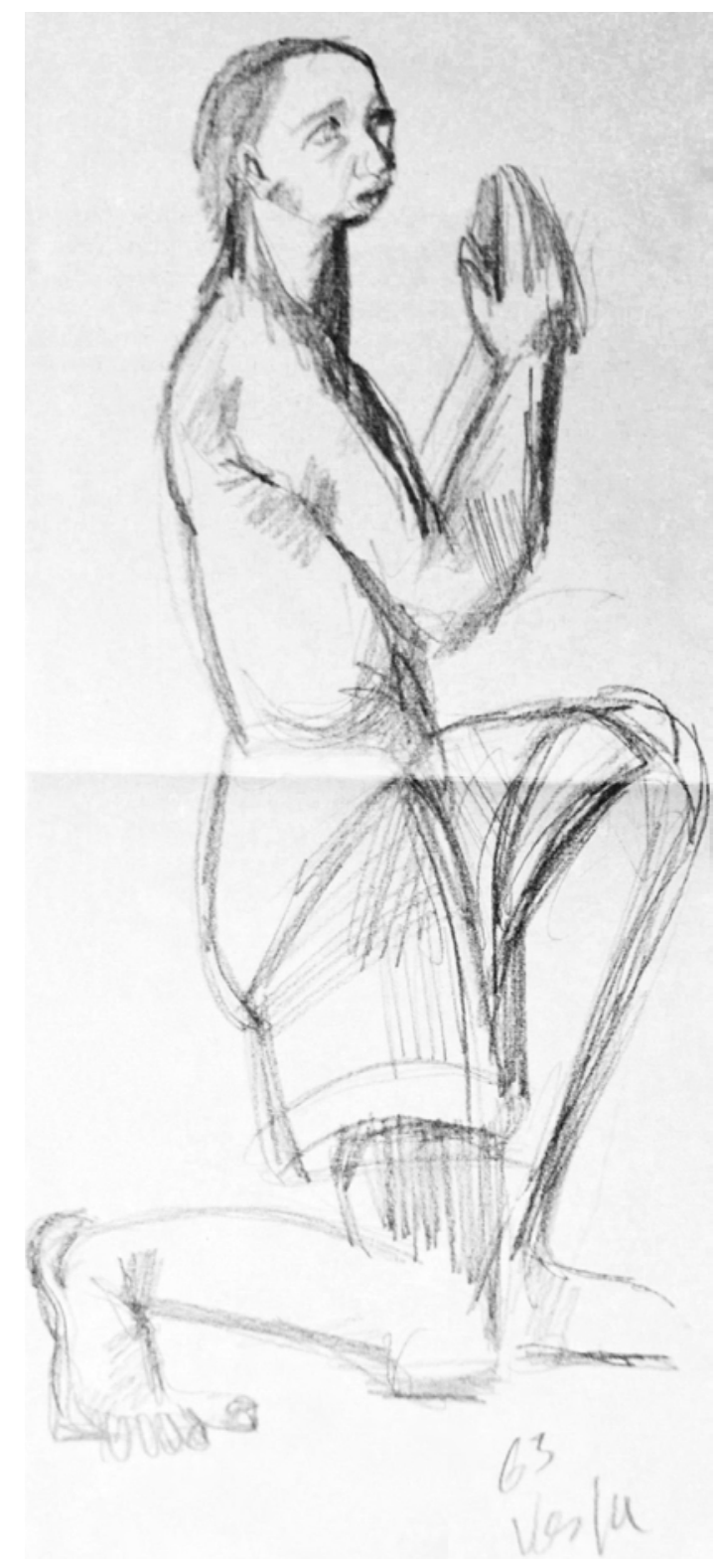




\section{INTRODUÇÃO}

\section{[O ARQUITETO]}

Quanto ao texto inicial dessa dissertação, a introdução apresentará o arquiteto que não é o objeto dessa pesquisa, mas sim, fio condutor para essa tese de mestrado. A introdução contará com informações sobre o arquiteto Geraldo Vespaziano Puntoni, que deveriam ser entendidas como base de sua postura arquitetônica, política e humana. Muitas vezes restam signos ou resquícios de uma memória, e através de sua junção é possível resgatar aquele passado valioso para a construção do nosso futuro. Essa introdução é o ponto de partida para essa colagem de signos, que vai permear os capítulos a seguir, passando pelos seis órgãos ou empresas públicas do estado, tentando amarrar essa vida do funcionário público, arquiteto e professor Geraldo Vespaziano Puntoni.

Nascido em 1932 em Brotas, interior de São Paulo, foi criado pelo avô - dono de um grande armazém: Seu destino era ser comerciante.
Geraldo Vespaziano Puntoni inicialmente não tinha nenhuma perspectiva de fazer qualquer curso além do curso escolar. Na época isso era o suficiente para trabalhar no comércio. Um tio despertou-se pelo interesse do sobrinho em desenhar, um momento significativo para a formação do futuro arquiteto Geraldo Vespaziano Puntoni. Com o objetivo de fomentar o talento do seu filho, a mãe o levou para estudar no Colégio Bandeirantes na cidade de São Paulo, onde Geraldo Vespaziano Puntoni, mostrou-se um aluno exemplar, enquanto morava na casa de seu tio.

Depois do segundo ano no colégio, Geraldo Vespaziano Puntoni conseguiu uma vaga no Colégio Estadual Presidente Roosevelt, situado no Parque Dom Pedro. Sua mãe pagava a pensão e a sua formação só foi possível devida a essa transferência gratuita. Vespaziano Puntoni mudou-se para o Largo do Correio e, na mesma
IMAGEM 2. Desenho Geraldo Vespaziano Puntoni, 1962, Fonte: Arquivo do Sílvio Breno de Souza Santos. 


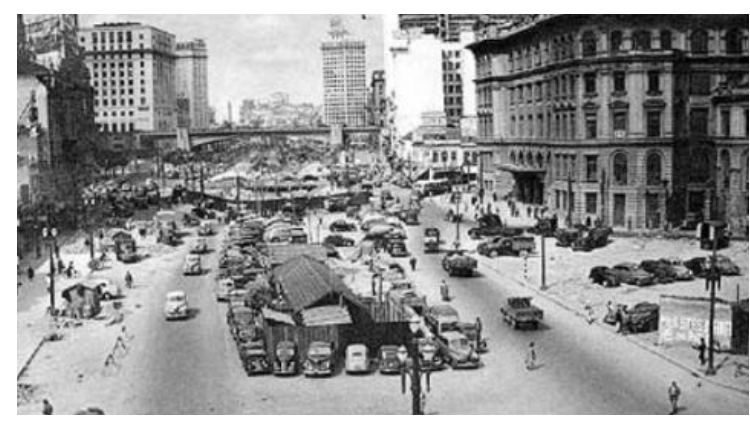

IMAGEM 3. Construção da passagem subterrânea (buraco do Adhemar) no cruzamento com Av. São João, tendo a direita o prédio dos correios e praça de mesmo nome, 1950, Fonte: http://netleland.net/tag/buraco-do-ademar

14 época assistiu o começo da obra do »Buraco do Adhemar« (1948). Pela janela do quarto o futuro arquiteto, observava essa obra importante para o urbanismo da cidade de São Paulo. Depois do ensino fundamental, fez o colegial científico, também no Colégio Presidente Roosevelt, na Rua São Joaquim na Liberdade.

Nessa época o aluno Vespaziano Puntoni conheceu pessoalmente o escritor Alfonso Schmidt (1890-1964) e começou a estudar seus livros. Em suas narrativas, o autor fala da cidade de São Paulo e dos bairros que o arquiteto Vespaziano Puntoni frequentava na época. $\bigcirc$ jovem ficou surpreendido pela quantidade e qualidade de descrições de ambientes urbanos. Alguns anos depois, como arquiteto e professor da FAU USP, ele se recordou dessa leitura, e a publicou na revista Sinopses $n^{\circ} 27$ da FAU USP (1997) um artigo chamado »Desenhos de observação e de memória: fragmentos de uma experiência«. A partir das descrições dos ambientes do Brás no livro "Aventuras de Indalécio", de Afonso Schmidt, o arquiteto resolveu produzir alguns desenhos de memória desses espaços urbanos. Depois de visitar o lugar, fazer a verificação do existente, e a recordação da sua própria memória, o arquiteto procurou representar os ambientes através de desenhos de observação e de memória. Parte dessa apresentação na revista Sinopses é um texto de Afonso Schmidt, que representa em conjunto com os desenhos de Geraldo Vespaziano Puntoni com ar dessa época:

\section{»O dia estava magnifico. As várzeas doura-} das pelo sol, os transeuntes apresentando ar festivo. o balão do gasômetro aparecia muito alto, batido pela claridade, com manchas claras nas grades de ferro. À roda da fábrica do gás, alinhavam-se extensos muros de tijolos vermelhos, descarnados. O bonde passou diante do portão da esquina. Lá dentro havia uma fila de vagonetes de coque, empurrados por operários de boné, calças azuis e sapatos de corda. Três fornos abriam a bocarra viva, onde as chamas davam baile, como bailarinas vermelhas. Nas imediações, o ar que se respirava estava impregnado de um cheiro agradável de carvão de pedra. 
O bonde virou a travessa do Brás. Carrocinhas de sorveteiros estavam encostadas ao meio fio. Chamavam a atenção pelas bandeiras de cores cruas. No largo do Brás, o quiosque parecia igualmente em festa. Bandeiras encharcadas pela chuva da noite iam e vinham à mercê do vento. Uma dúzia de indivíduos descalços, chapéu batido na testa, rodeavam o quiosque; bebiam, comiam, contavam proezas. Quando o bonde passou pela vizinhança, sentiu o cheiro forte do café que estava sendo coado àquela hora. Lobrigou Onofre a discutir com um vendedor de gasparinhos.

Próximo à rua Vasco da Gama, apeou. Na esquina, quatro homens discutiam vivamente o espetáculo da véspera, no grêmio dramático. Um citava com admiração o nome de certo amador. O mais próximo respondeu-lhe como outro. Àquele sim é que era o gênio. E, quando Indalécio passou por eles, a conversa tinha azedado; um já falava em partir a cara do outro...

O primeiro quarteirão da rua Vasco da Gama compunha-se de pequenas casas de uma porta de duas janelas. Todos verdes, com a tinta a despren- der-se. De quando em quando um portão. Nos pátios interiores viam-se puxados de tábuas, telheiros de zinco e casebres de cair de velhos. Nesses cortiços morava gente como formiga. Detrás de cada porta saía uma criança. Detrás de cada janela espiava uma mulher, de lenço na cabeça. «1

Uma outra influência significativa para sua formação foi o próprio bairro onde Geraldo Vespaziano Puntoni passou a sua infância, na cidade de Brotas, no interior de São Paulo. Ao longo dessa pesquisa observa-se uma conduta social como norte para a formação do arquiteto. O bairro vizinho ao seu tinha uma número alto de negros e era chamado de »Pita Acesa«. Ele mesmo cresceu em um bairro italiano, e acabou ficando amigo de vários. Juntos, andavam descalços, com poucas roupas e desatentos, segundo os relatos de Geraldo Vespaziano Puntoni. As mães, muitas vezes eram prostitutas e, ainda criança, Geraldo Vespaziano Pun-

1 SCHMIDT Afonso. Aventuras de Indalécio. São Paulo: Clube do Livro. 1951, p. 106 e 107) 


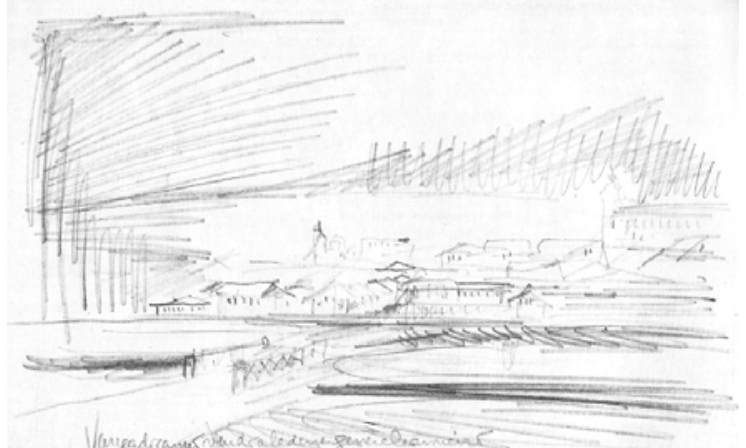

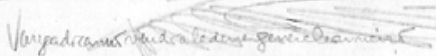

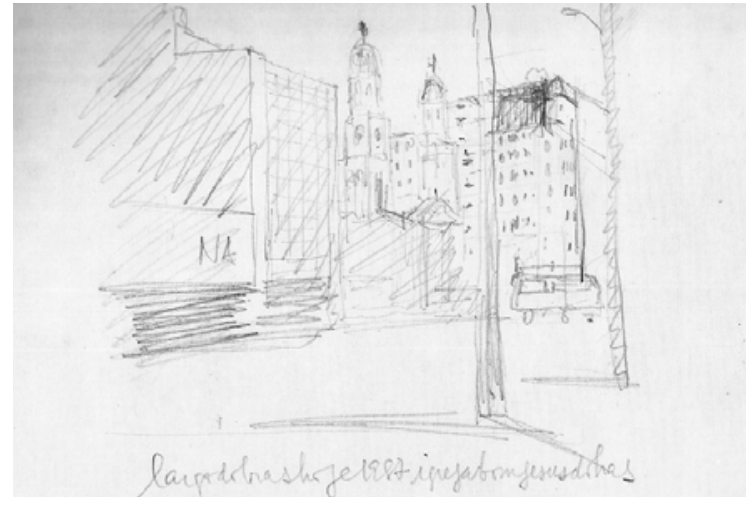

IMAGEM 5. Geraldo Vespaziano Puntoni, Revista Sinopses FAU USP, 1997, Título do desenho: Largo do Brás, hoje 1997, Igreja Bom Jesus do Brás

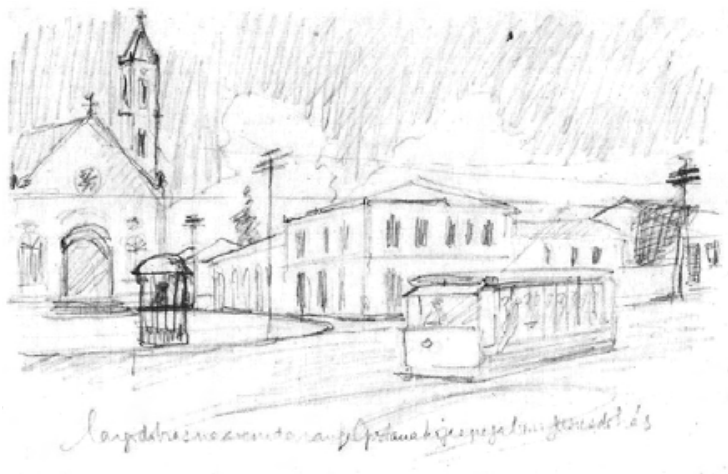

MAGEM 6. Geraldo Vespaziano Puntoni, Revista Sinopses FAU USP, 1997, Título do desenho: Largo do Brás em frente da Igreja Bom Jesus do Brás.
1997. Títu Geraldo Vespaziano Puntoni, Revista Sinopses FAU US Carneiro 


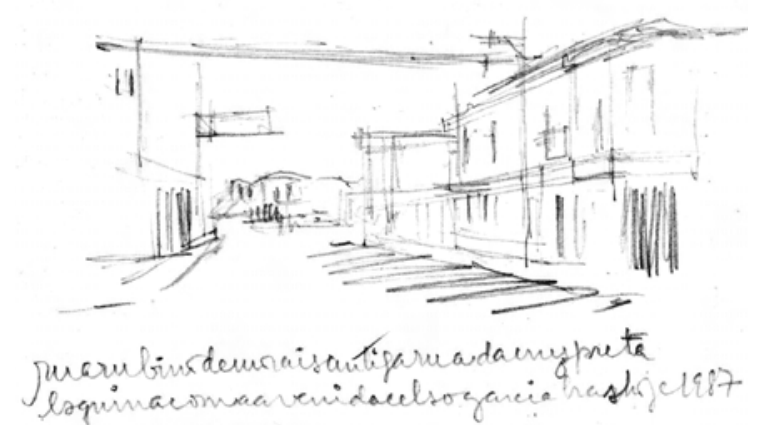

IMAGEM 7. Geraldo Vespaziano Puntoni, Revista Sinopses FAU USP, 1997, Título do desenho: Rua Rubino de Morais, Antiga Rua da Cruz Preta, Esquina com Avenida Celso Garcia, Hoje 1987

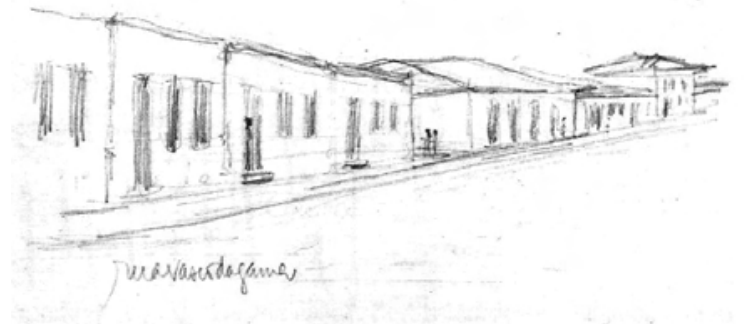

IMAGEM 8. Geraldo Vespaziano Puntoni, Revista Sinopses FAU USP, 1997, Título do desenho: Rua Vasco da Gama

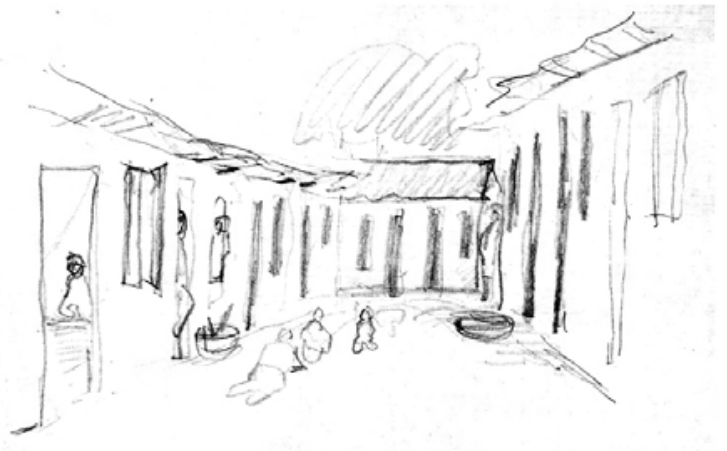

IMAGEM 9. PUNTONI, Geraldo Vespaziano, Revista Sinopses FAU USP, 1997, Título do desenho: Sem 
toni sentiu a discriminação sofrida pela classe mais baixa. Os italianos apelidavam o bairro vizinho de "Pita Acesa", porque não tinha luz nem esgoto. As vezes aparecia uma luz para logo depois desaparecer de novo. Segundo Geraldo Vespaziano Puntoni, o apelido foi tão difundido com o passar do tempo, que o bairro dos italianos também passou a ser conhecido como bairro do »Pita Aceso«. O nome se espaIhou sem fazer distinção entre classes sociais. Talvez sua conduta social atual seja um reflexo de sua infância. Geraldo Vespaziano Puntoni não queria estudar arquitetura, ele preparava-se para o vestibular de medicina; foi uma amizade que levou o futuro arquiteto para outros rumos. Na escola, Geraldo Vespaziano Puntoni conheceu Eduardo de Almeida (1933) e, juntos, começaram a frequentar os museus e galerias de arte na cidade de São Paulo. As conversas e discussões sobre arte contemporânea levaram os dois amigos finalmente para a Faculdade de Arquitetura e Urbanismo na Universidade de São Paulo (FAU USP), onde começaram a estudar arquitetura. Geraldo Vespaziano Pun- toni começou a faculdade em 1953 e formou-se em 1959. Seu colega Eduardo de Almeida terminou a graduação um ano depois, em 1960.

A pessoa Geraldo Vespaziano Puntoni, fio condutor dessa pesquisa, é uma pessoa altamente engajada na política. A análise de arquitetura pode se livrar das posturas políticas, pois uma análise de projeto costuma ser vinculado em diretrizes racionais, como por exemplo proporções, fluxos ou a implantação de uma edificação no sítio. No caso do arquiteto Geraldo Vespaziano Puntoni, essa separação entre posturas políticas e trabalhos desenvolvidos precisam ser compreendidos como conjunto. É importante ressaltar que o engajamento político do arquiteto, com todas as suas vertentes, teve uma parte fundamental em sua formação. Seja como estudante, seja como arquiteto dento dos órgãos públicos do estado, ou como arquiteto autônomo.

O primeiro contato com a política começou cedo: Ainda aluno, no colégio Presidente Roosevelt, Geraldo Vespaziano Puntoni partici- 
pou do movimento estudantil chamado União Paulista dos Estudantes Secundaristas - UPES.

grupo atuou diretamente na resistência à ditadura do Estado Novo de Getúlio Vargas (1937-1945) e no combate ao nazi-fascismo no país. Segundo Geraldo Vespaziano Puntoni, houve um ataque violento dos integralistas durante um congresso da UPES no Sindicato dos Barbeiros, na Avenida Consolação. Esse acontecimento, em 1945, marcou o jovem estudante, e criou ao mesmo tempo, os seus primeiros laços com o partido comunista (PCB).

Em 1953 Geraldo Vespaziano Puntoni entrou como estudante na FAU USP, e logo inscreveu-se na União Juventude Comunista - UJC. Em paralelo, ele se engajou no Grêmio da FAU USP e virou vice presidente. Durante toda a década de 50, a atenção do Grêmio ficou voltada para as questões culturais mais gerais e para discussões sobre a produção arquitetônica da época, caracterizada por tendências diversas, presentes na FAU a partir de seus professores. Mas já na década de 50 o Grêmio promovia várias atividades e tinha grande participação política dentro e fora da faculdade e da Universidade. Segundo Geraldo Vespaziano Puntoni, o trabaIho era interessante, importante e significativo, até o ponto em que ele assumiu a presidência do Diretório Estudantil de Juscelino Kubitschek durante a campanha em 1955. A dedicação na campanha de JK tomou tanto espaço, que ele foi reprovado no curso de arquitetura. $\mathrm{Na}$ entrevista em fevereiro de 2014, o arquiteto Geraldo Vespaziano Puntoni recordou-se dessas turbulências e das consequências causadas pelo engajamento na politica estudantil:

»Mas isto foi bom! Para mim foi mais importante ter sido presidente do Diretório Estudantil do JK. Não ganhei nada com isso, mas ganhei experiência. O JK ganhou, então compensou! Brasília foi construída! $\ll^{2}$

Exatamente essa nova capital, foi visitada por Geraldo Vespaziano Puntoni, ainda antes da sua

2 Entrevista, Geraldo Vespaziano Puntoni, 26.02.2014

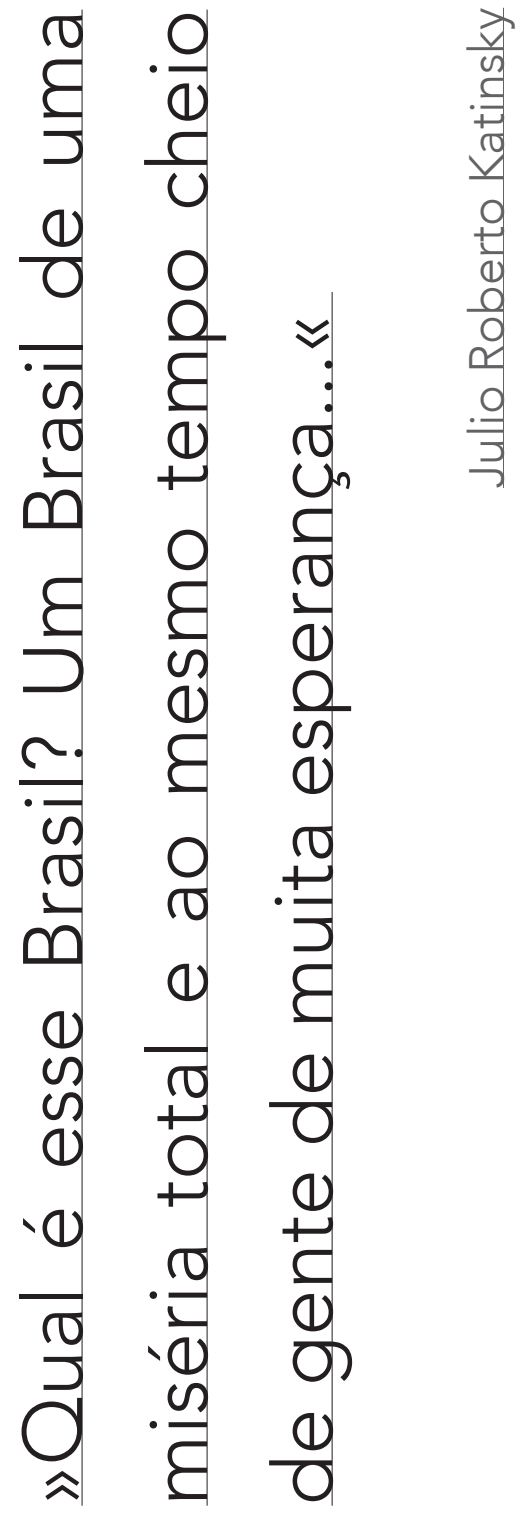




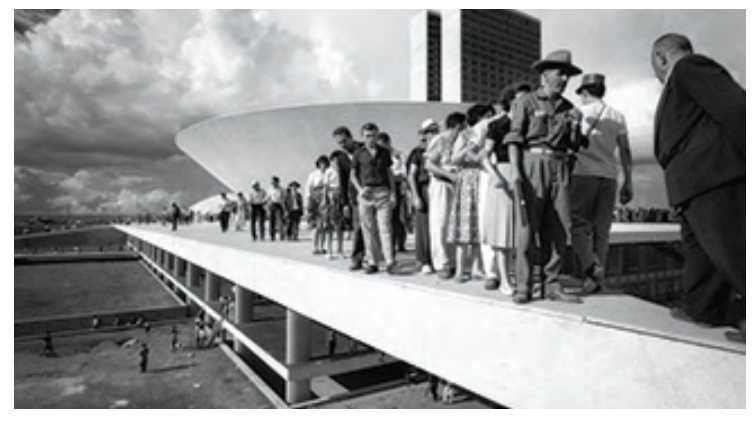

IMAGEM 10.Foto: Thomaz Farkas, Pessoas passeiam na entrada do Congresso em 1960, Fonte: http://zonacurva.com.br/brasilia-nao-tem-culpa/ inauguração em 1960, talvez em compensação pelo ano difícil que teve durante a campanha. A passagem aérea foi um presente de um parente distante, Dr. Dante Pazzanese ${ }^{3}$. Em Brasília, Geraldo Vespaziano Puntoni participou de um congresso do sindicato dos arquitetos. Além dessa viagem, conseguimos identificar uma outra, feita com alguns amigos da FAU USP. Em janeiro de 1955, os estudantes Geraldo Vespaziano Puntoni, Ubyrajara Gilioli, Julio Roberto Katinsky e Janusz Wlodzimierz Wojdyslawski desceram o rio São Francisco. A viagem revela o interesse dos jovens arquitetos em »descobrir - Brasil«. Essa viagem é a expressão da vontade de entender a realidade brasileira, que oscila entre miséria e esperança:

»A idéia da viagem de descer o rio São Francisco era a de conhecer o Brasil, tínhamos que colaborar na construção do país. Nós descemos o

3 PAZZANESE, Dante (1900-1975) foi um médico cardiologista brasileiro, fundador da Sociedade Brasileira de Cardiologia. Em 1954 fundou o Instituto de Cardiologia do Estado de São Paulo, que mais tarde receberia o nome de Instituto Dante Pazzanese de Cardiologia.
São Francisco, fomos até Juazeiro. Saímos de São Paulo e fomos até Barra do Piraí. De Barra do Piraí, pegamos um trem que era um horror e fomos para Pirapora. Lá tem uma queda d'água e começa um São Francisco tranquilo até Paulo Afonso, até parado. Fomos cantando o tempo todo. Éramos estudantes, não podíamos pagar, dormimos em tudo quanto foi biboca possível. E em Juazeiro nós pegamos o trem e fomos até Bonfim. Chegamos em Salvador, lá eu tinha um amigo, que conheci num congresso, e ele cavou um monte de coisa para nós na Reitoria [...] Por fim nós cavamos um monte de coisa e ficamos lá. Então essa foi uma viagem importante para nós, não no sentido de colher muito material folclórico, porque não tínhamos competencia para isso. Mas foi importante para ver um Brasil que ninguém conhecia na faculdade. Qual é esse Brasil? Um Brasil de uma miséria total e ao mesmo tempo cheio de gente de muita esperança..." ${ }^{4}$

4 Julio Roberto Katinsky ingressou na FAU-USP em 1952 e se formou em 1957. Entrevista realizada em 28/01/2009 para o Mestrado "Arquitetura e Viagens de formação pelo Brasil 1939-1962, João Clark de Abreu Sodré" 
Durante a viagem ao longo do rio São Francisco o grupo conheceu uma pessoa do Partido Comunista do Brasil (PCB), suponha-se que ele foi à missão de campanhas políticas nessas regiões, juntando o poder dos agricultores, pois as ligas camponesas eram fortes na época. $\bigcirc$ contato com essa pessoa foi interessante para os jovens arquitetos. $\bigcirc$ político, cujo nome não conseguimos identificar, tinha contatos com os líderes do partido. $\bigcirc$ entusiasmo desse político levou o arquiteto Geraldo Vespaziano Puntoni em participar de um curso de »Agitprop $\aleph^{5}$ no Rio de Janeiro. Agitprop é uma abreviação de agitação e propaganda, uma ideia do marxismo-leninismo que diz respeito à disseminação das ideias e princípios do comunismo entre traba-

5 O Partido Comunista Soviético criou em 1920 um Departamento de Agitação e Propaganda, que era parte do Secretariado do Comitê Central, que tinha por missão usar a arte como uma arma revolucionária num País degradado pela guerra e marcado pela ilitercia. Para os adeptos das ideias marxistas-leninistas, é utilizado como ferramenta para divulgação do Movimento Revolucionário e a existência do partido. Basicamente, $\mathrm{o}$ ativismo político e social é conduzido por organizações de base, organizações de massa e movimentos populares com o intuito de agitar a sociedade, dar visibilidade ao movimento, aos conflitos entre trabalhadores, sociedade e geral e o governo. Agitprop, influenciou fortemente o projeto »Fun Palace do arquiteto britânico Cedric Price, um projeto aconselhado, pela diretor teatral Joan Littlewood.
Ihadores, camponeses, estudantes, intelectuais e formadores de opinião na sociedade em geral.

»Eu fui para um lugar clandestino, sem saber o percurso, foi algo ilegal. Eu aprendi tudo [...] estudamos Marx, Lenin e todos os documentos essenciais. Havia um trabalho de educação pelo partido. A gente nunca soube quem eram as pessoas, as vezes identificamos os sotaques. $\|^{2}$

Podemos considerar as três viagens para Brasília, rio São Francisco e sua participação no evento de Agitprop no Rio de Janeiro como experiências fundamentais na formação do jovem arquiteto. Separando as viagens em três categorias de aprendizagem: Cidade, Geografia e Política. Evidentemente a viagem para Brasília deixou as suas marcas - Geraldo Vespazino Puntoni é um arquiteto moderno. Não somente pela visita à Brasília, e pela convivência com os arquitetos dessa época como Rui Gama, Rino Levi ou Vilanova Artigas, com quem ele trabaIhou durante sua formação. Ele é um arquiteto moderno, por convicção, ele achava que a cha-

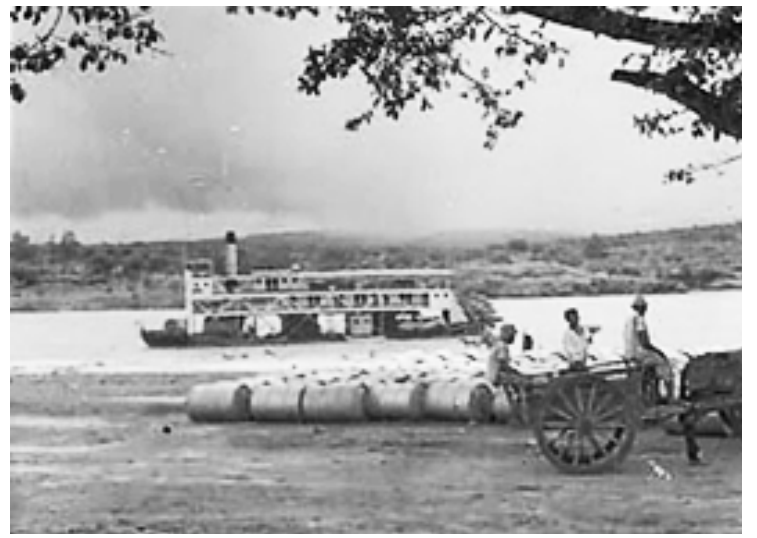

IMAGEM 11. Foto: Ubyrajara Gilioli, Barca utilizada na viagem pelo rio São Francisco, janeiro de 1955. Arquivo de Ubyrajara Gilioli. 


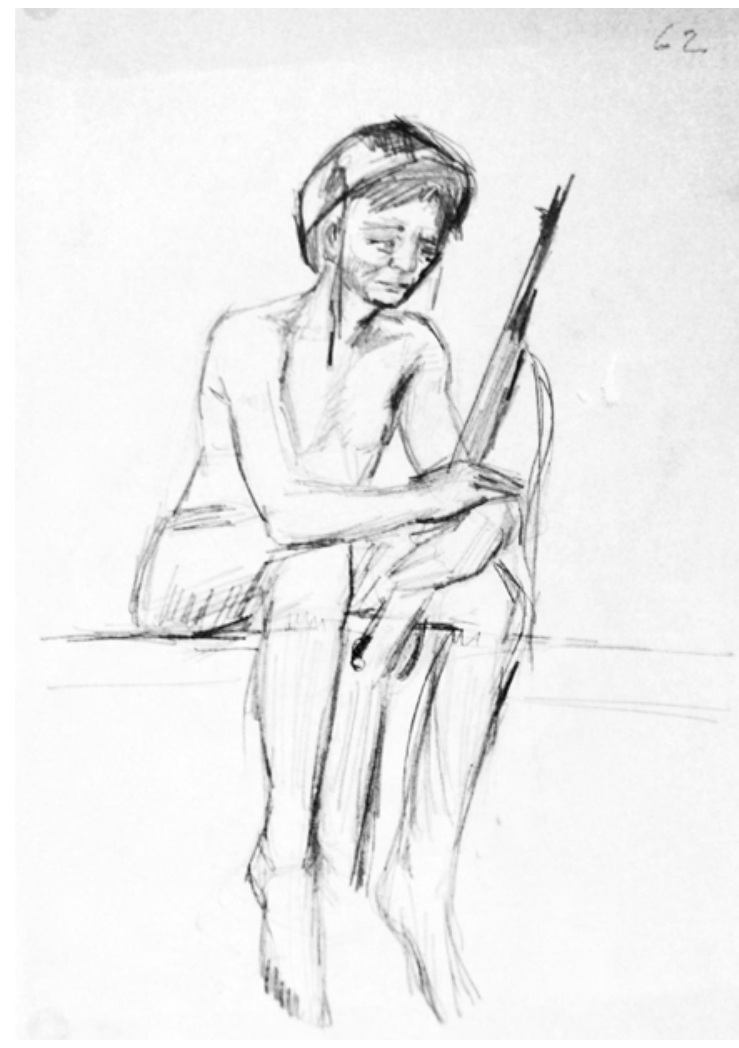

IMAGEM 12. Desenho Geraldo Vespaziano Puntoni, 1962, Fonte: Arquivo do Sílvio Breno de Souza Santos.

22 ve de um país mais justo e mais humano, encontrava-se na modernidade e na industrialização da construção. Para Geraldo Vespaziano Puntoni, a arquitetura moderna não é definida apenas por formas mais puras, realizadas com uma técnica contemporânea, sobretudo, ele entendeu arquitetura moderna como a tentativa de participar, no nível da construção do ambiente, na transformação da sociedade.

Um dos integrantes da viagem foi o estudante Janusz Wlodzimierz Wojdyslawski, que depois de formado na FAU USP, virou sócio do Arquiteto Geraldo Vespaziano Puntoni. Janusz era judeu polonês, sobrevivente do extermínio da Segunda Guerra Mundial, seus pais eram médicos e foram deportados e mortos pelos nazistas. Segundo Geraldo Vespaziano Puntoni, Janusz tinha uma tia, que o trouxe para o Brasil. se tornou mais comunista do que todos os outros colegas. Um menino com uma inteligência, impressionante! Ele era um cara »desagradável« mas muito interessante. $\|^{6}$

Vespaziano Puntoni se recorda de um diálogo entre amigos que estavam fazendo CPOR (Serviço Militar), quando um deles virou para Janusz e disse:

»Nós fomos dar um tiro com um canhão de $75 \mathrm{~mm}$, deu um recuo e quase machucou a gente.« Janusz respondeu: »James, um canhão de $75 \mathrm{~mm}$ não tem recuo! «²

Depois de formados, Janusz Wojdyslawski e Geraldo Vespaziano Puntoni montaram um escritório na Rua Vieira de Carvalho. Janusz tinha contatos na sociedade judaica, relações que facilitaram o começo do escritório. Depois mudaram-se para o Palácio do Comércio na Rua 24 de Maio, onde dividiam o espaço com Ruy

6 Entrevista, Geraldo Vespaziano Puntoni, 26.02.2014 
Ohtake, que não chegou a ser sócio do escritório, mas contribuiu para alguns projetos, como por exemplo o concurso para a Escola Federal de São Paulo. Logo depois o arquiteto Ruy Otake deslanchou e se transformou em um dos arquitetos mais conhecidos de São Paulo. Os caminhos de Geraldo Vespaziano Puntoni e do seu sócio Janusz Wojdyslawski foram diferentes: Geraldo Vespaziano Puntoni casou-se em 1960 com Elisa Helena Lanna Puntoni. Portanto, o arquiteto estava em busca de uma vida mais estável, pois ele tinha em mente construir uma família. Consequentemente o arquiteto Geraldo Vespaziano prestou um concurso para o Departamento de Obras Públicas - DOP em 1961

»Então, como o DOP sempre foi encarado? Agora eu me posiciono, sempre foi encarado como um subemprego [...] eu eduquei meus filhos, criei minha família, construí a minha casa como funcionário publico. $\ll^{7}$

7 Entrevista, Geraldo Vespaziano Puntoni, 19.03.2014 $\bigcirc$ arquiteto Janusz Wojdyslawski adoeceu, contraiu pancreatite e morreu jovem em abril de 1974, deixando sua mulher Mitzi Wojdyslawski e seus filhos Leo e Marcos Wojdyslawski.

\section{Edifício de Apartamentos \\ na Rua Bahia (1962)}

Mesmo assim o escritório Puntoni/Wojdyslawski apresentava uma produção significativa de projetos em diversas escalas, desde residências, edifícios habitacionais e escolas até uma capela. Os arquitetos atuaram num campo amplo e diversificado. A apresentação de duas obras exemplares representam de forma clara as discussões da época. Por um lado foram influenciados pelos pensamentos dos arquitetos Vilanova Artigas e Paulo Mendes da Rocha, que, além de exercerem a profissão de arquiteto, tinham a pretensão de reformular propostas que vinculavam a produção arquitetônica a um desenvolvimento industrial. Nessa concepção cabia aos arquitetos auxiliarem o desenvolvimento industrial no seu campo específico, isto 


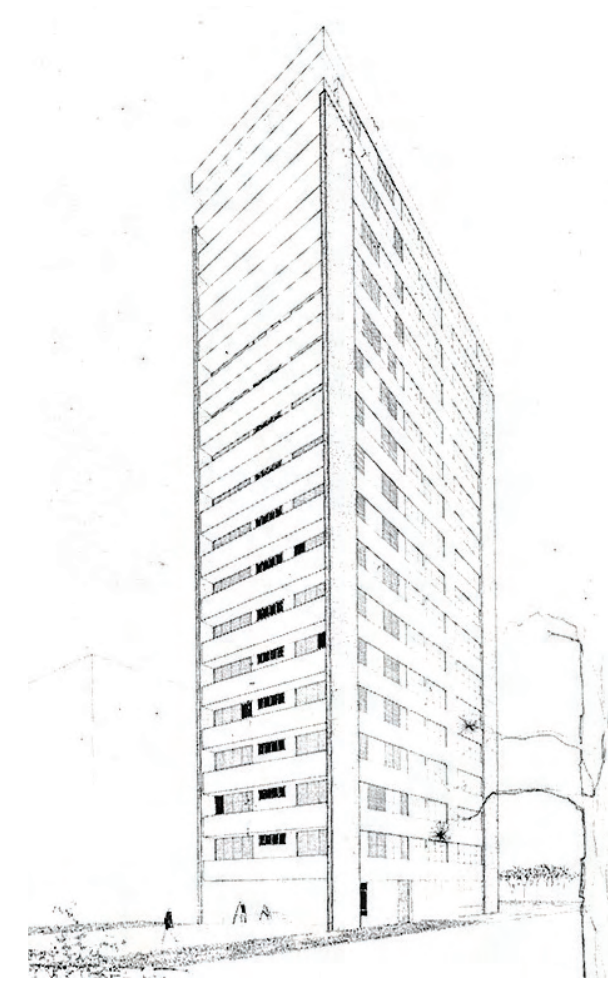

IMAGEM 13. Perspectiva, Edifício de Apartamentos, Rua Bahia, Higienópolis, São Paulo, Arquitetos Puntoni e Wojdyslawski. 1962. Fonte: Acrópole. n. 297 , v. 25,1963 . p. 266 é, da construção civil, propondo o uso franco de novos materiais, com um desejo de uma industrialização da construção. No exemplo do Edifício de Apartamentos na Rua Bahia (1962) a sua arquitetura não é vista necessariamente uma »arte de construir ${ }^{8}$, termo usado pelo Hannes Meyer desde, sucessor de Gropius na direção da Bauhaus. No projeto da Rua Bahia parece que construir tornou-se uma ciência, ou seja, arquitetura como ciência da construção. A construção não é uma questão de sentimento, mas sim de conhecimento técnico. $\bigcirc$ projeto da Rua Bahia destacou-se na época por causa da sua escolha estrutural e foi publicado na revista Acrópole em 1963. Foram dois fatores que interviram na decisão estrutural;

a.) A necessidade de grandes vãos inferiores para a garagem;

b.) $\bigcirc$ gabarito de altura mínima.

Diante dessas condições eliminou-se desde

8 MEYER, Hannes. Thesen über eine marxisitsche Architektur. In Hannes Meyer - Bauen und Gesellschaft. Dresden 1980 cedo uma possibilidade de estrutura de transição, que exigiria uma espessura estrutural elevada para garantia de deformações mínimas. Assim, uma solução em lajes nervuradas de $11,20 \mathrm{~m}$ de vão foi adotada; a par da vantagem da necessidade de transição tal esquema estrutural garantiu ampla versatilidade ao projeto. Quer seja pela necessidade de obter uma solução econômica, ou pela necessidade de compensar as cargas permanentes para reduzir o valor de deformação lenta, uma solução protendida desde logo foi considerada. Obtido um momento de protenção quase idêntico ao das cargas permanentes, os valores de deformação lenta foram atenuados em 75\%, possibilitando o emprego de peças muito mais esbeltas.

Essa obra insere-se num momento em que, as promessas do Governo Juscelino Kubitschek pareciam prestes a se tornar realidade. Os progressistas tinham a sensação que o país só sairia do atraso tecnológico, industrial e político, se desse consistência às políticas industriais e às propostas que se espelhavam na industria- 
lização. Entretanto, o desenvolvimentismo do governo JK engatilhou uma série de problemas econômicos e sociais que tiveram seu estopim no golpe militar em 1964, encerrando um período, marcado pelos governos do Jânio Quadros e João Goulart. Em 1962, no mesmo ano da construção do projeto Rua Bahia, os arquitetos Sérgio Ferro, Rodrigo Lefèvre e Flávio Império, formaram-se pela Faculdade de Arquitetura e Urbanismo da USP. Foram portanto a primeira geração de arquitetos modernos brasileiros posterior à construção de Brasília. Esse grupo de arquitetos criticou a arquitetura moderna brasileira e suas relações com o processo de modernização, por desconhecer a realidade do país. Segundo Lefèvre, as propostas se basearam em um conceito de industrialização irreal, propostas de laboratório, que do ponto de vista social, penalizaram o trabalhador no canteiro de obra. O funcionário do canteiro era responsável por suprir as carências tecnológicas da produção.

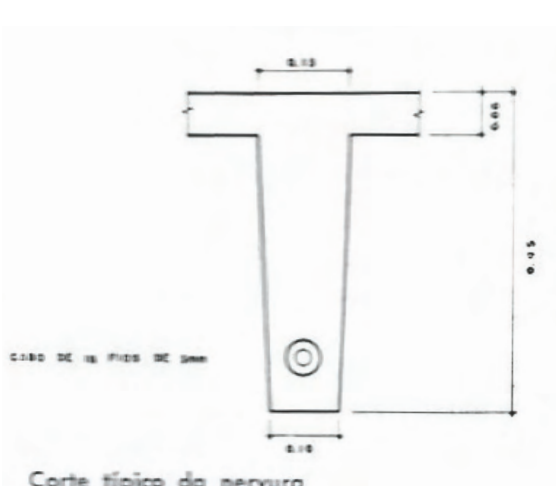

Corte tipico do nervuro
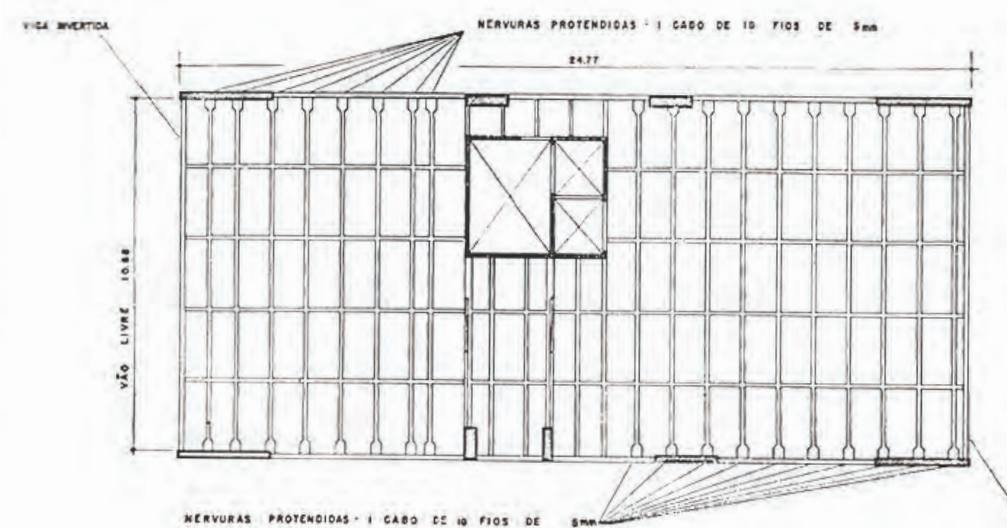

IMAGEM 14. Esquema Estrutural, Edifício de Apartamentos, Rua Bahia, Higienópolis, São Paulo, Arquitetos Puntoni e Wojdyslawski. 1962. Fonte: Acrópole. n. 297, v. 25, 1963. p. 266

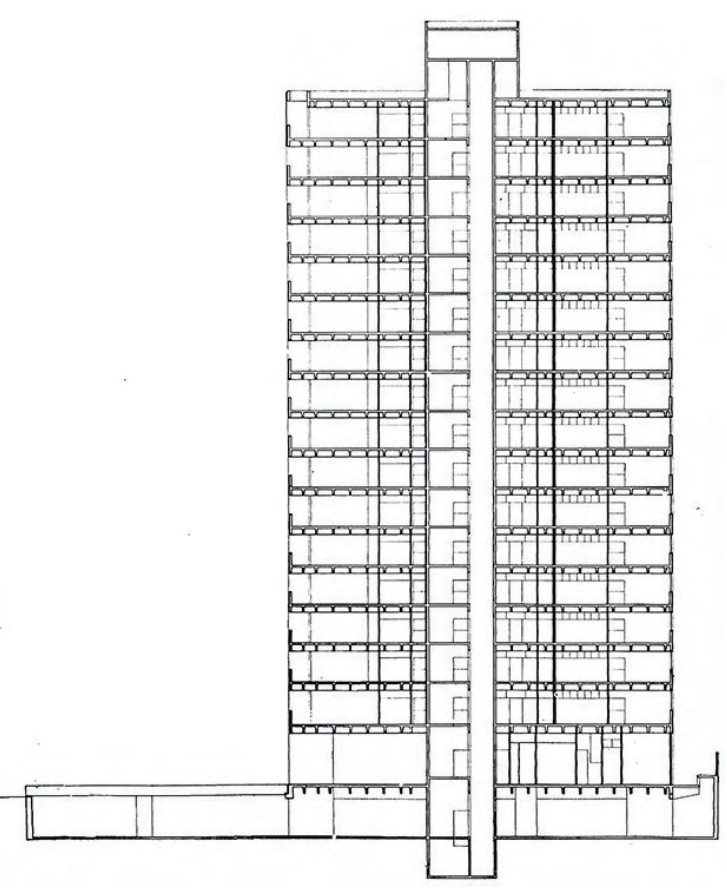

IMAGEM 15. Corte, Edifício de Apartamentos, Rua Bahia, Higienópolis, São Paulo, Arquitetos Puntoni e Wojdyslawski. 1962. Fonte: Acrópole. n. 297, v. 25,1963 . p. 266 
1. Rampa

2. Garagem

3. Hall de serviço

4. Esplanada

5. Entrada de serviço

6. Hall social

7. Copa

8. Sala

9. Cozinha

10. Banheiro

11. Terraço de serviço

12. Dormitório

13. Salão de festas

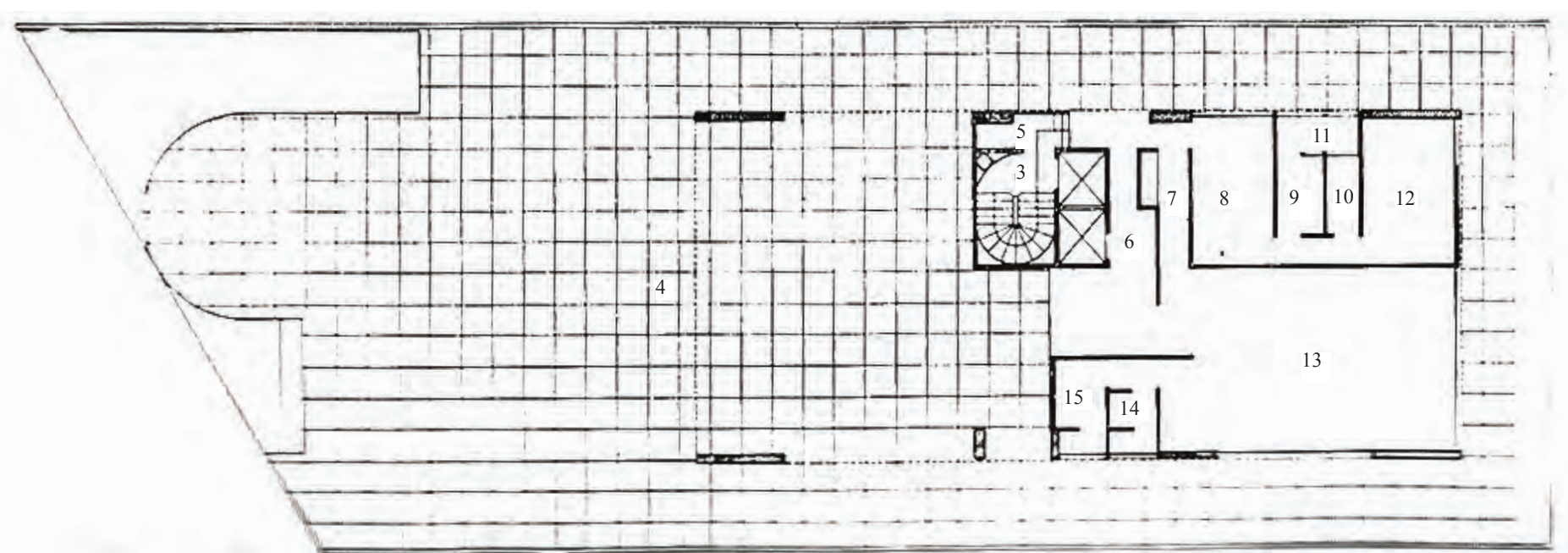

IMAGEM 16. Pavimento térreo, Edifício de Apartamentos, Rua Bahia, Higienópolis, São Paulo, Arquitetos Puntoni e Wojdyslawski. 1962. Fonte: Acrópole. n. 297, v. 25, 1963. p. 266 
14. W.C. Masculino

15. W.C. Feminino

16. Lavanderia

17. Rouparia

18. Circulação

19. Vestiário

20. Terraço de Serviço

21. Quarto de Empregada

22. Vestíbulo

23. Escritório

24. Sala de Jantar

25. Sala de Estar

26. Toilette

27. W.C. Empregada

28. Adega

29. Terraço

30. Caixa D’água

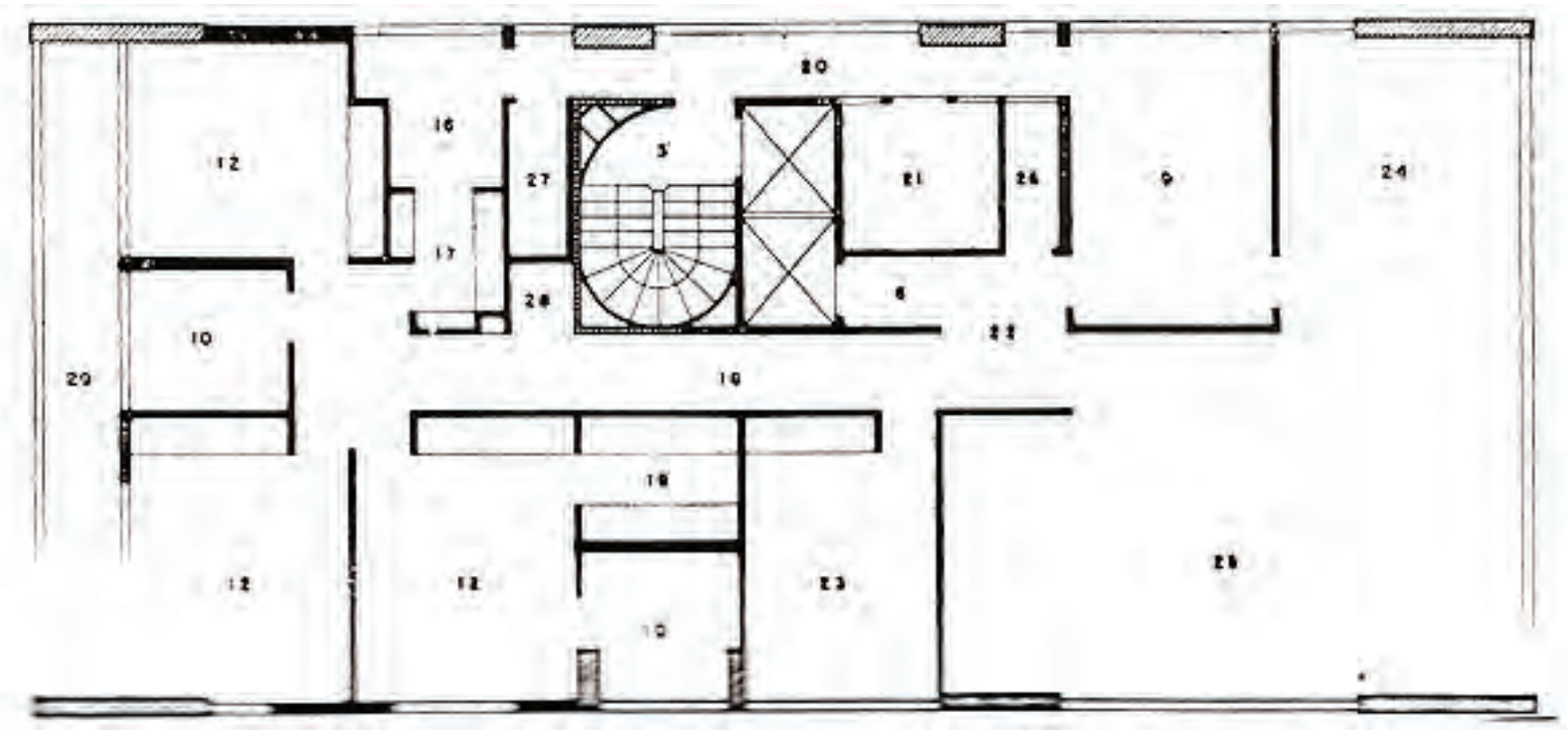

IMAGEM 17. Pavimento tipo, Edifício de Apartamentos, Rua Bahia, Higienópolis, São Paulo, Arquitetos Puntoni e Wojdyslawski. 1962. Fonte: Acrópole. n. 297, v. 25, 1963. p. 266 


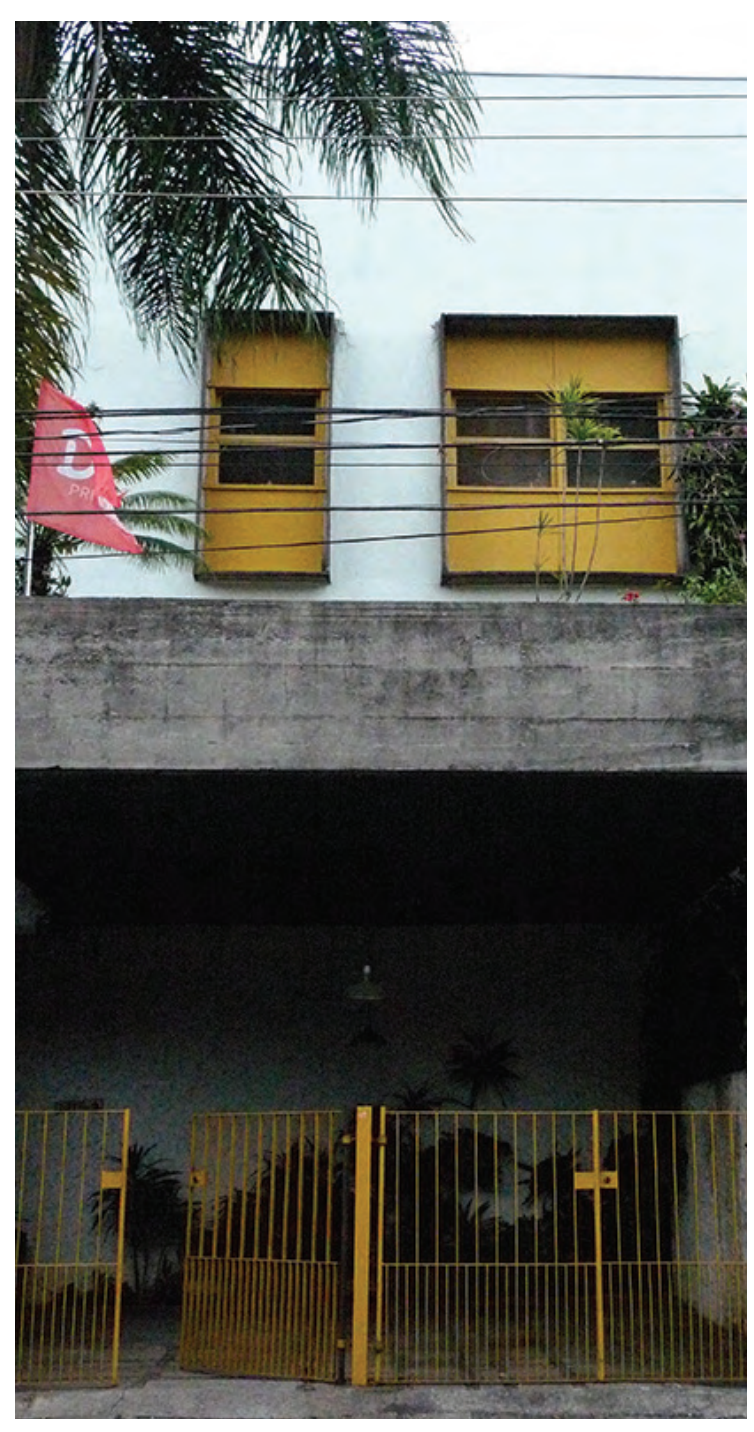

IMAGEM 18. Casa Puntoni, fachada para Rua, Fonte: Sebastian F. Beck 28

\section{A CASA DO ARQUITETO (1972)}

A casa do arquiteto Geraldo Vespaziano Puntoni representa, com sua austeridade e ausência de pretensão o pensamento da linguagem da "arquitetura nova «". A casa pratica uma "poética da economia«, ou seja, uma construção relativamente simples, cuja otimização de procedimentos aumentou a produtividade e o acesso à arquitetura. $\bigcirc$ projeto é concebido como casa geminada, que compartilha o tipo de estrutura, materiais e outros produtos industrializados com o vizinho, com objetivo de diminuir os custos e aumentar a eficiência na construção.

A casa do arquiteto Geraldo Vespaziano Puntoni, onde reside até hoje, foi construída em 1972,

9 Grupo Arquitetura Nova, constituído por Sérgio Ferro, Rodrigo Lefèvre e Flávio Império, foi um grupo formado pela Faculdade de Arquitetura e Urbanismo da USP em 1962 - pertencente, portanto, à primeira geração de arquitetos modernos brasileiros posterior à construção de Brasília. Evidentemente influenciados pelos mestres Niemeyer, da chamada $»$ Escola Carioca«, e sobretudo por Artigas, da »Escola Paulista«, realizaram uma reflexão crítica acerca da arquitetura brasileira produzida então, bem como de suas perspectivas diante do fim da euforia nacional-desenvolvimentista que caracterizara o governo JK, com o advento do regime militar. ou seja, dez anos depois do Edifício Rua Bahia. Esses dez anos revelam um processo de amadurecimento e sua casa permanece como obra de reflexão para Geraldo Vespaziano Puntoni e consequentemente para essa pesquisa:

»[...] o projeto é o início, o meio e não o final de um processo pois permanece como objeto de consulta durante

a vida útil do construído, e pelo seu sentido de permanência.«

Abrahão Sanovicz

A casa do arquiteto Geraldo Vespaziano Puntoni é uma construção de dois andares assentados em um lote pequeno de $30,00 \mathrm{~m}$ por $10,00 \mathrm{~m}$ e com declive acentuado. A Rua João da Cruz Mellão determina o limite do estacionamento do Estádio do Morumbi. Umas das qualidades dessa rua é a abundância de árvores e tráfego concedido aos moradores da rua. $\bigcirc$ volume da casa é recuado a uma certa distância da rua. Entre a rua e o volume da casa se insere o abrigo de carros e uma escada que convi- 
Obra

Arquiteto

Local

Ano do projeto

Proprietário

Profissão

Composição familiar

Estrutura

Paisagismo

Interiores

Período construção

Área terreno

Área ocupada

\% ocupação

Área construida

Área útil
Residência Puntoni

G. Vespaziano Puntoni

R. João da Cruz Mellão,

N²21, Jardim Leonor

1972

G. Vespaziano Puntoni Arquiteto

1 casal e 2 filhos

Antônio Pinto Rodrigez Luciano Fiaschi

Arquitetura Paisagística

G. Vespaziano Puntoni

1972-1973

$300,00 \mathrm{~m}^{2}$

$143,45 \mathrm{~m}^{2}$

47,82

193,2

$142,20 \mathrm{~m}^{2}$

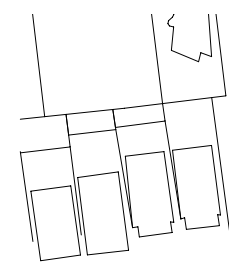

$\square$

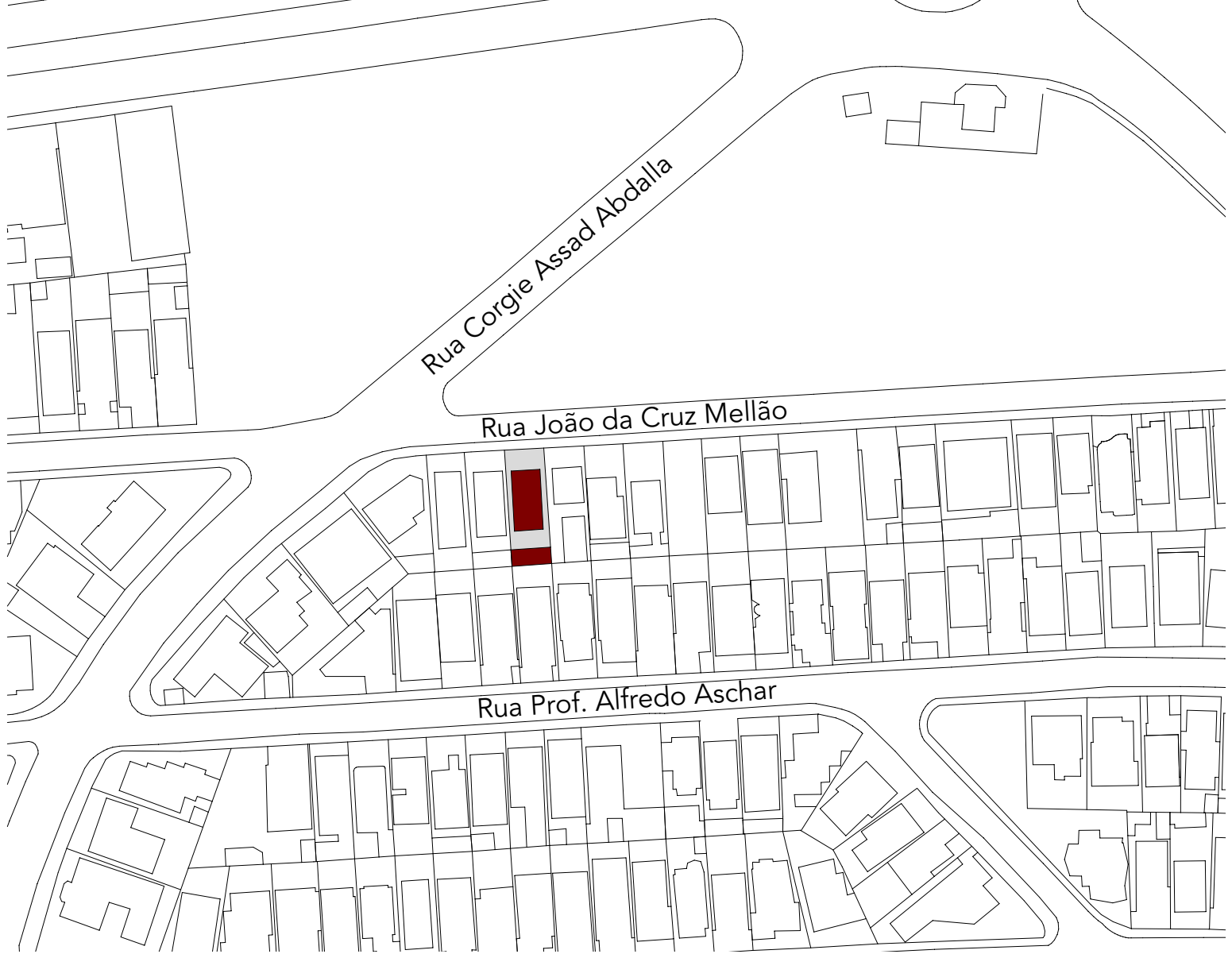

Planta de Situação Esc. 1:2000 


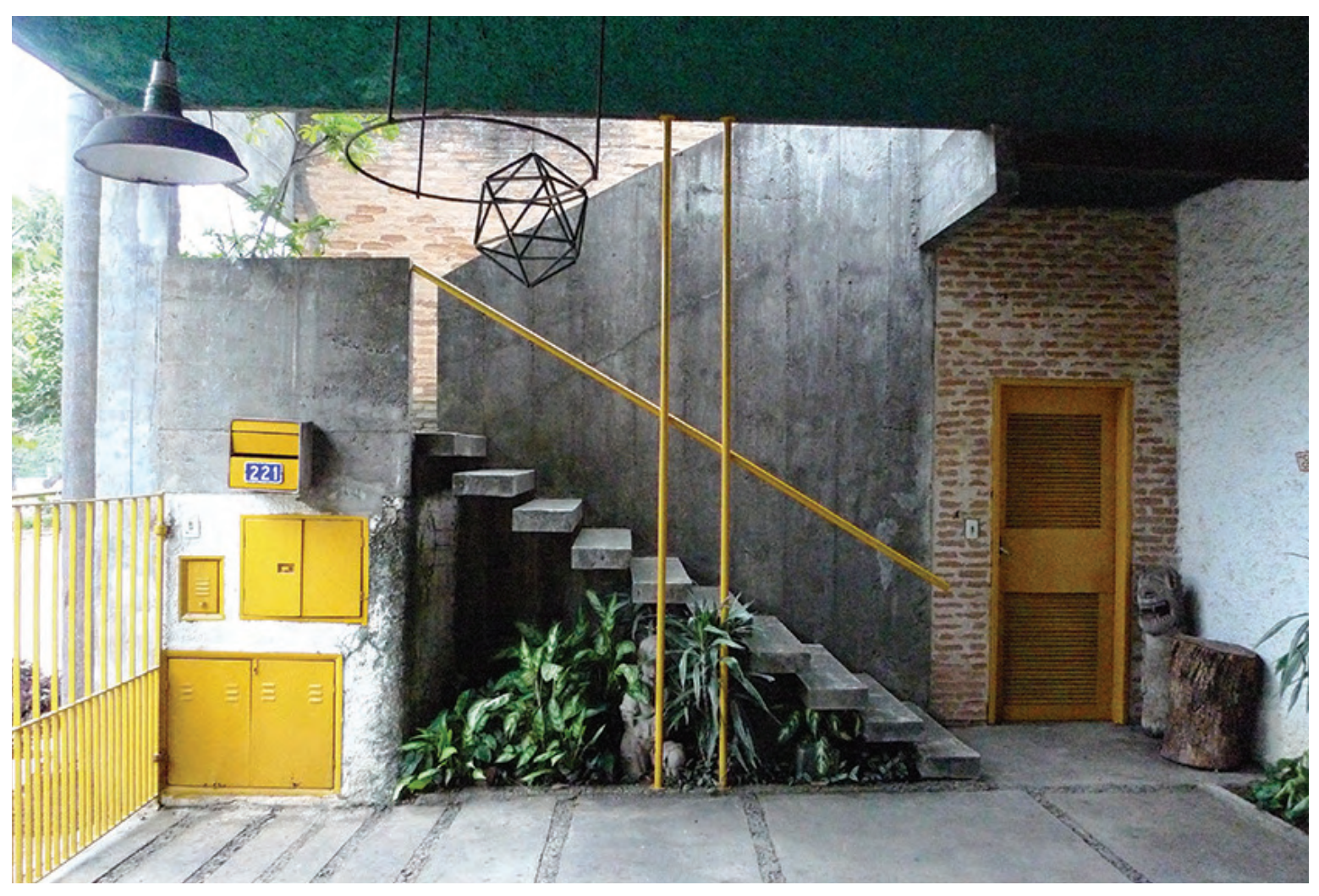

da a subir através dos traços amarelos do fino corrimão. A casa é implantada de forma a ser possível percorrer em volta de seu perímetro.

Na face leste e na face oeste da casa se destacam os dois terraços. $\bigcirc$ terraço na fachada leste tem uma vista para as copas das árvores, um jardim no meio nível entre o abrigo de carros e terraço penetra através de um vazio. Bancos de concreto armado definem os lados do terraço. terraço do fundo, na face oeste, é diferente, como uma espécie de pátio, ou seja, mais introvertido, pois é determinado pelos muros laterais e um muro de arrimo aonde existe um jardim de 1,50m acima da cota do pátio. Entre esses dois terraços estende-se a casa com todos seus usos particulares. O desnível entre as duas áreas do exterior é superado através do meio nível entre a sala de estar (face leste/terraço) e a sala de jantar (face oeste/pátio). Internamente, a casa organiza-se a partir da escada que conecta os dois meios níveis e percorre o nível superior da casa.

IMAGEM 19. Casa Puntoni, Escada e garagem, Fonte: Sebastian F. Beck

30 
Ao longo da fachada sul, escritório, hall, lavabo e área de serviço formam um espaço com funções que servem ao programa social da casa com sala de estar e sala de jantar. Em frente à área de serviço, se encontra uma cozinha linear com área mínima que tem de um lado o plano de trabalho e do outro, os armários. A área da lavandaria, contígua à cozinha e as janelas tipo »basculante«, virado no sentido vertical, propiciam luz e ventilação.

No pavimento superior, os dormitórios estão expostos à fachada leste. Os dois dormitórios menores eram antigamente um dormitório maior. A divisão, uma parede de madeira, foi construída depois. As janelas amarelas, do tipo "ideal", se destacam na elevação para a rua. A cor foi escolhida pelo arquiteto, para qualificar o branco da fachada. O banheiro, consequentemente localizado na fachada sul, como no andar inferior, é dividido em três compartimentos, uma "ante sala" com lavatórios, separada da cabina de bacia, bidê e da sala de banhos.

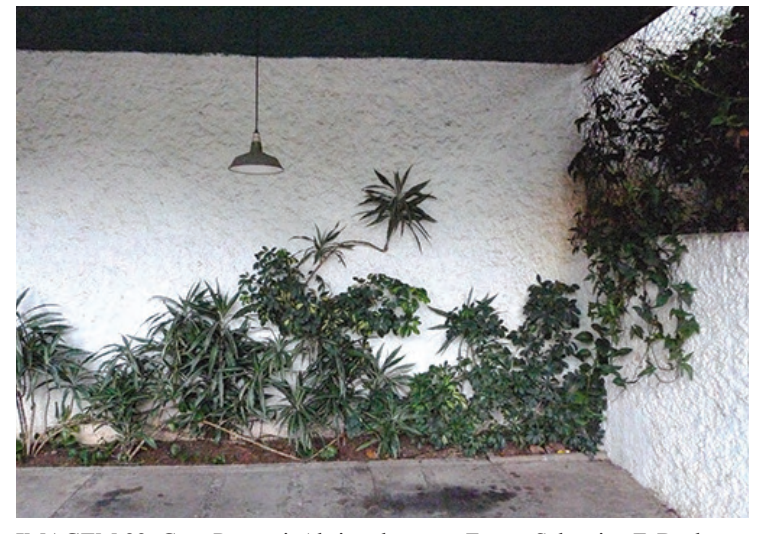

IMAGEM 20. Casa Puntoni, Abrigo de carro, Fonte: Sebastian F. Beck

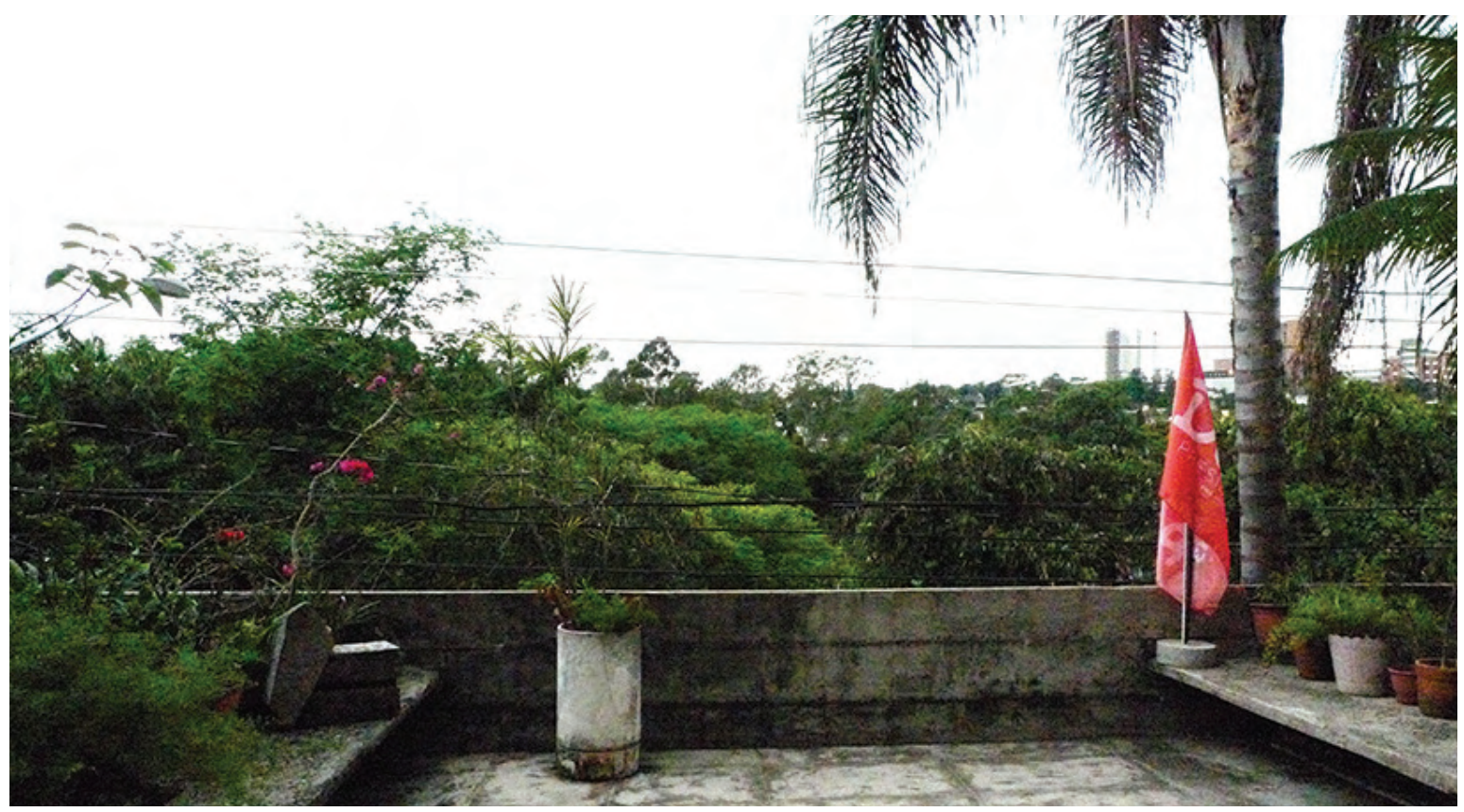

IMAGEM 22.Casa Puntoni, Terraço para rua, Fonte: Sebastian F. Beck

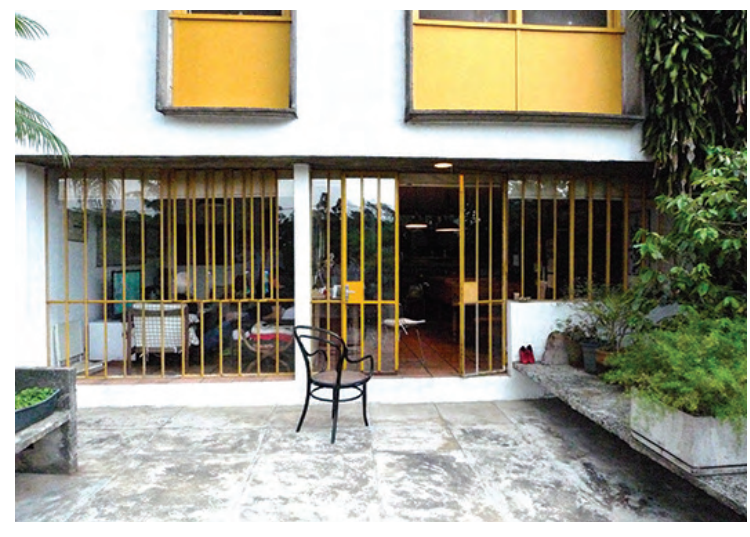

IMAGEM 21. Casa Puntoni, Terraço para rua, Fonte: Sebastian F. Beck 


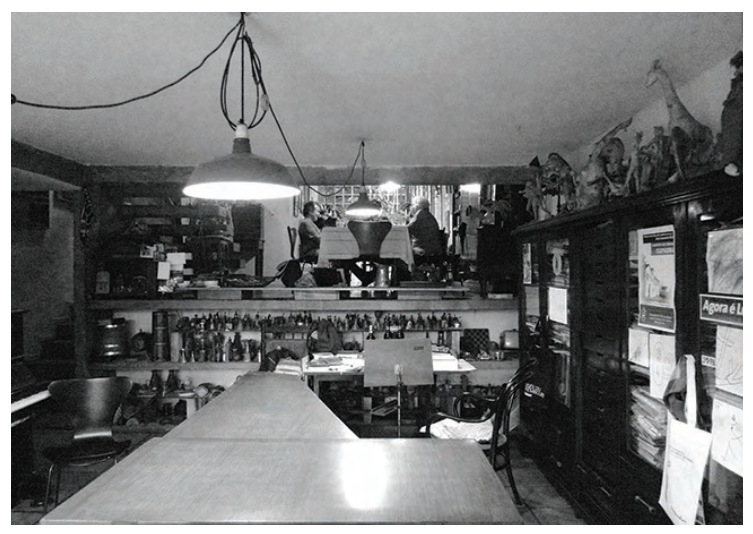

IMAGEM 23. Casa Puntoni, Sala de estar, Fonte: Sebastian F. Beck

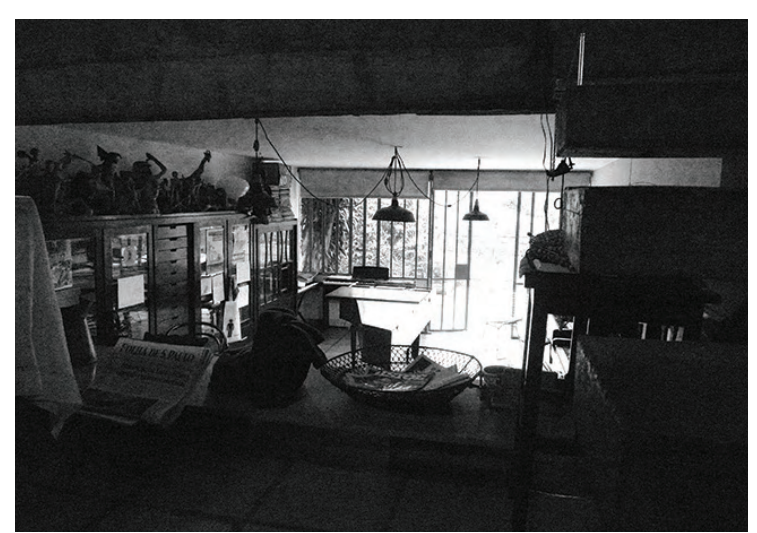

IMAGEM 24. Casa Puntoni, Sala de estar, Fonte: Sebastian F. Beck

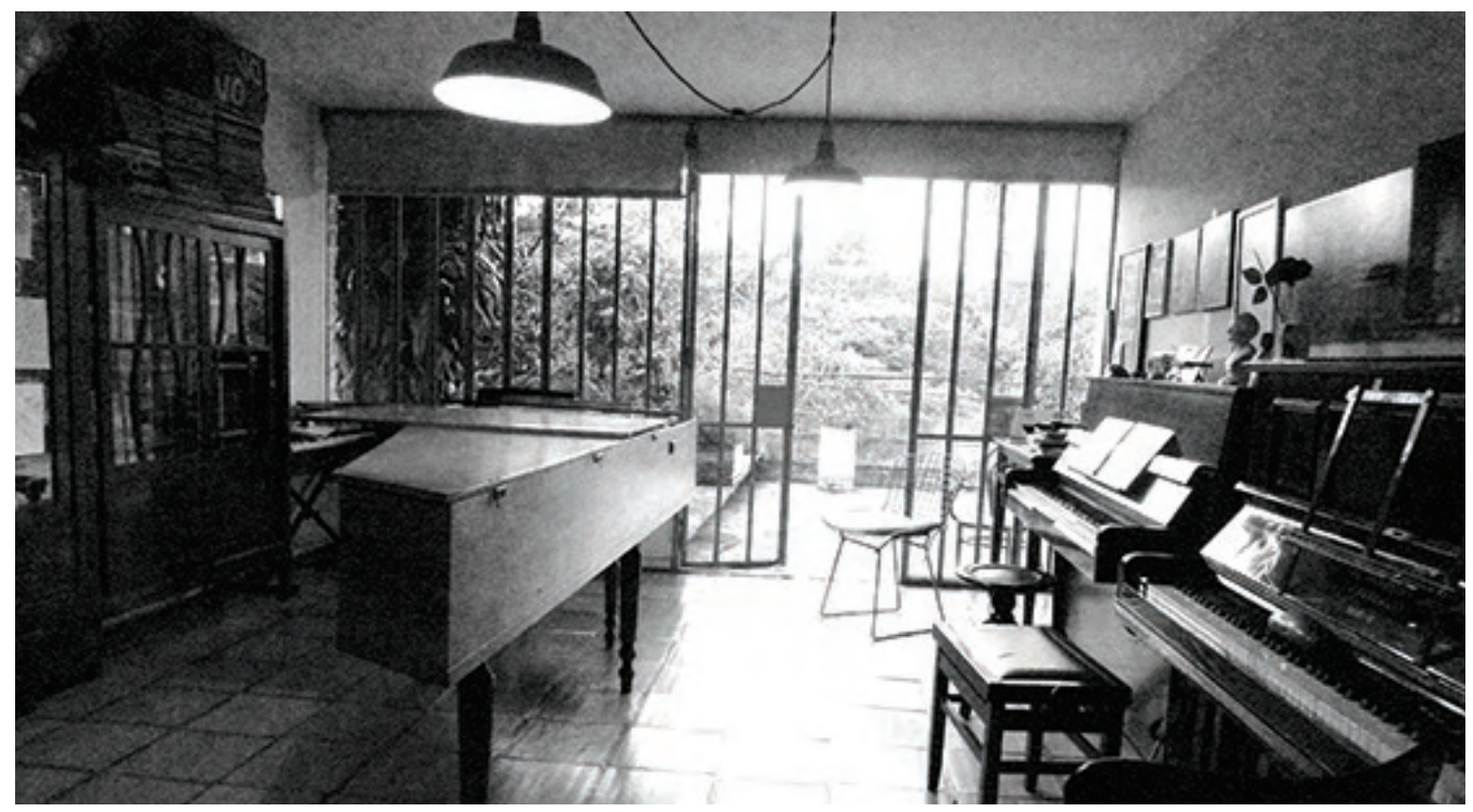

IMAGEM 25. Casa Puntoni, Sala de estar, Fonte: Sebastian F. Beck 32

A construção do volume da casa resulta da organização longitudinal dos espaços principais da sala de estar e da sala de jantar com as suas respectivas extensões nas áreas externas. Por isso, é possível enxergar até o terraço do fundo se olharmos através da casa, a partir do terraço na face leste.

Essa obra, é de certo modo, resultado construido de um modo de viver. Esse modo de viver revela uma postura arquitetônica, social e política do arquiteto Geraldo Vespaziano Puntoni. A sua forma de »morar« permite possíveis relações com sua atuação como funcionário público do estado e sua própria forma de criar arquitetura. Geraldo Vespaziano Puntoni entende arquitetura não somente como projeto; arquitetura é sua própria realização. »Arquitetura é o gesto da criação ${ }^{10}$ e ao mesmo tempo o lugar de reafirmação. Podemos considerar a própria casa do arquiteto como lugar de criação de saberes. Ou seja, a casa com sua austeridade, seu despretencionismo, com a verdadeira expressão do material, sua clareza de intenção, sua permea- 
bilidade espacial permite a construção de um ambiente que favorece à produção de conhecimento. A casa serve como testemunha de uma vida dedicada à arquitetura, e também, com toda sua modéstia, como testemunha de um funcionário público, cuja dedicação rebate na construção da cidade; do estado; e de um país.

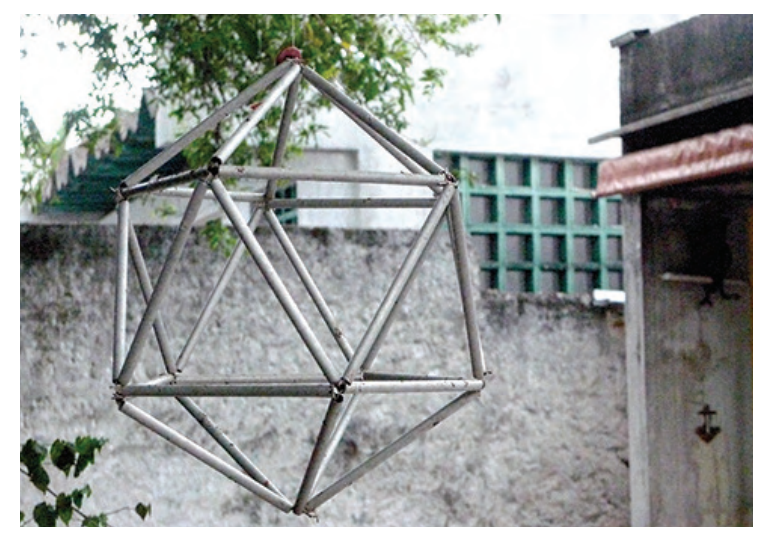

IMAGEM 26. Geraldo Vespaziano Puntoni, Escultura, Dodecaedro

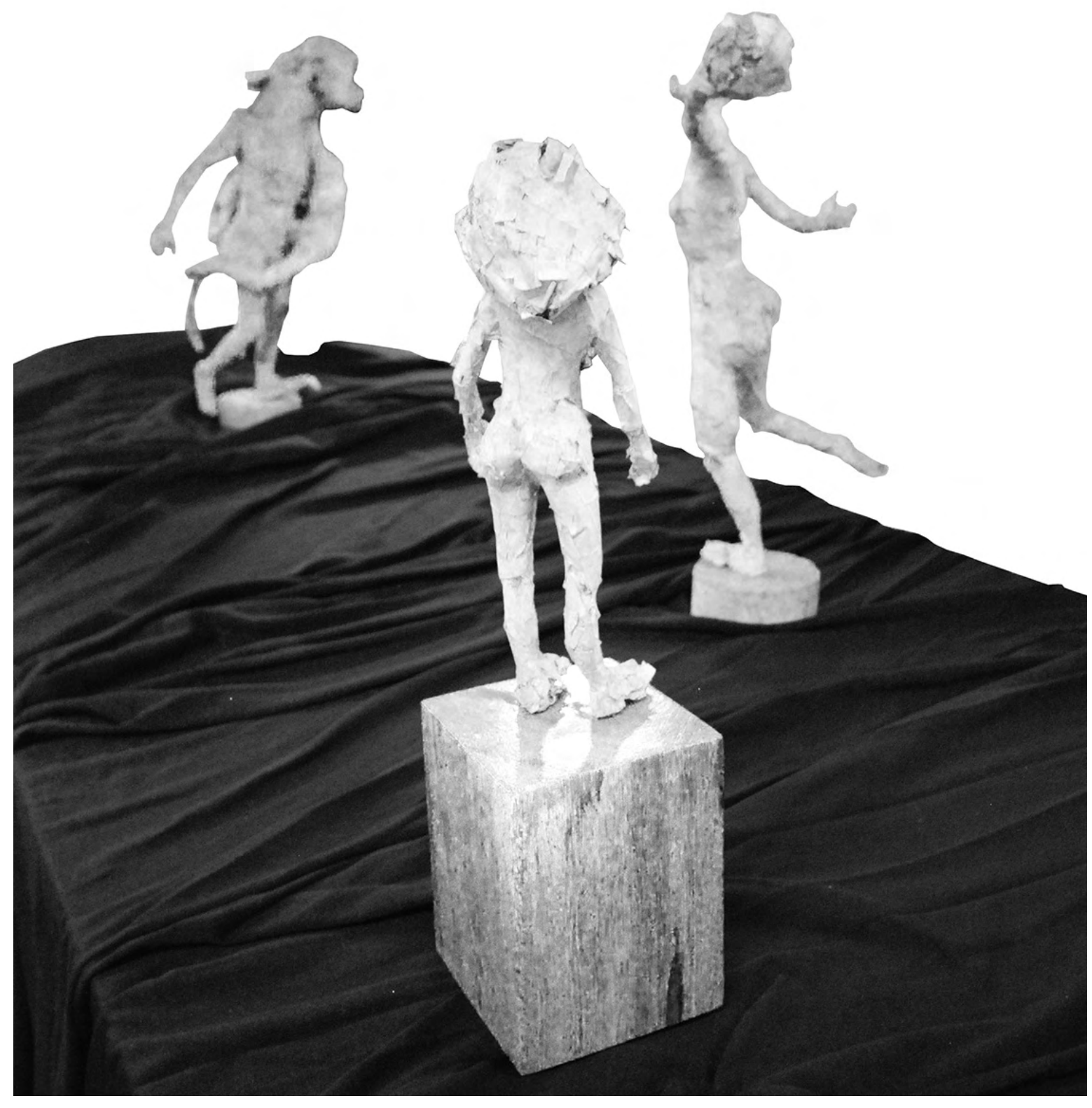

IMAGEM 27. Geraldo Vespaziano Puntoni, Três Esculturas de vita 


\section{Materiais empregados}

Estrutura

Laje

Alvenaria

Escadas

Esquadrias

Caixilhos

Vidros

Portas

Revestimento

Piso

Cores

34

\section{Concreto armado e tijolos}

Tijolo cerâmico e viga de concreto

Tijolos comum maciço, junta amarrada, meio tijolo

Concreto armado aparente, moldado in loco

Concreto armado aparente, moldado in loco

Caixilho "Ideal", caixilho de ferro perfis metálico, janela tipo "basculante"

Simples

Madeira

Concreto aparente, Argamassa pintada,

Paviflex (áreas úmidas),

Massa grossa (teto da garagem)

Ladrilhos cerâmicos (vermelho)

Piso cimentado (na área exterior),

Paviflex (áreas úmidas),

Elementos Pré-moldados armados (Fibonacci), juntas com concreto seco pedrisco

Luminária Tipo "Panela", de metal esmaltado, verde

Amarelo (Caterpillar), qualificar o branco das paredes. Verde escu-

ro no teto da garagem para diminuir visualmente a altura. 


\begin{tabular}{|c|c|c|}
\hline Programa & Componentes & Áreas \\
\hline \multirow[t]{6}{*}{ Social } & Hall & 6,05 \\
\hline & Sala de estar & 23,80 \\
\hline & Sala de jantar & 21,10 \\
\hline & Lavabo & 2,30 \\
\hline & Escritório & 9,90 \\
\hline & & 63,15 \\
\hline \multirow[t]{4}{*}{ Serviço } & Cozinha & 9,50 \\
\hline & Área de serviço & 8,95 \\
\hline & Sanitário & 1,70 \\
\hline & & 20,15 \\
\hline \multirow[t]{4}{*}{ Íntimo } & 3 dormitórios & 27,05 \\
\hline & 1 banheiro & 5,85 \\
\hline & Visita/suite & 26,00 \\
\hline & & 58,90 \\
\hline \multirow[t]{4}{*}{ Externo } & Abrigo de carros & 34,90 \\
\hline & 2 depósitos & 16,40 \\
\hline & 2 terraços & 51,95 \\
\hline & & 103,25 \\
\hline & Total & 245,45 \\
\hline
\end{tabular}

\section{Programa}

Dormitórios/

Sala de estar

Sala de jantar 
1. Terraço

2. Hall

3. Sala de estar

4. Escritório

5. Lavabo

6. Sala de jantar

7. Cozinha

8. Área de serviço

9. Sanitário

10. Depósito

11. Jardim

12. Abrigo de carro

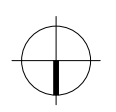

\begin{tabular}{lllllll}
0 & 1 & 2 & 4 & 6 & 8 & 10 \\
\hline & & &
\end{tabular}

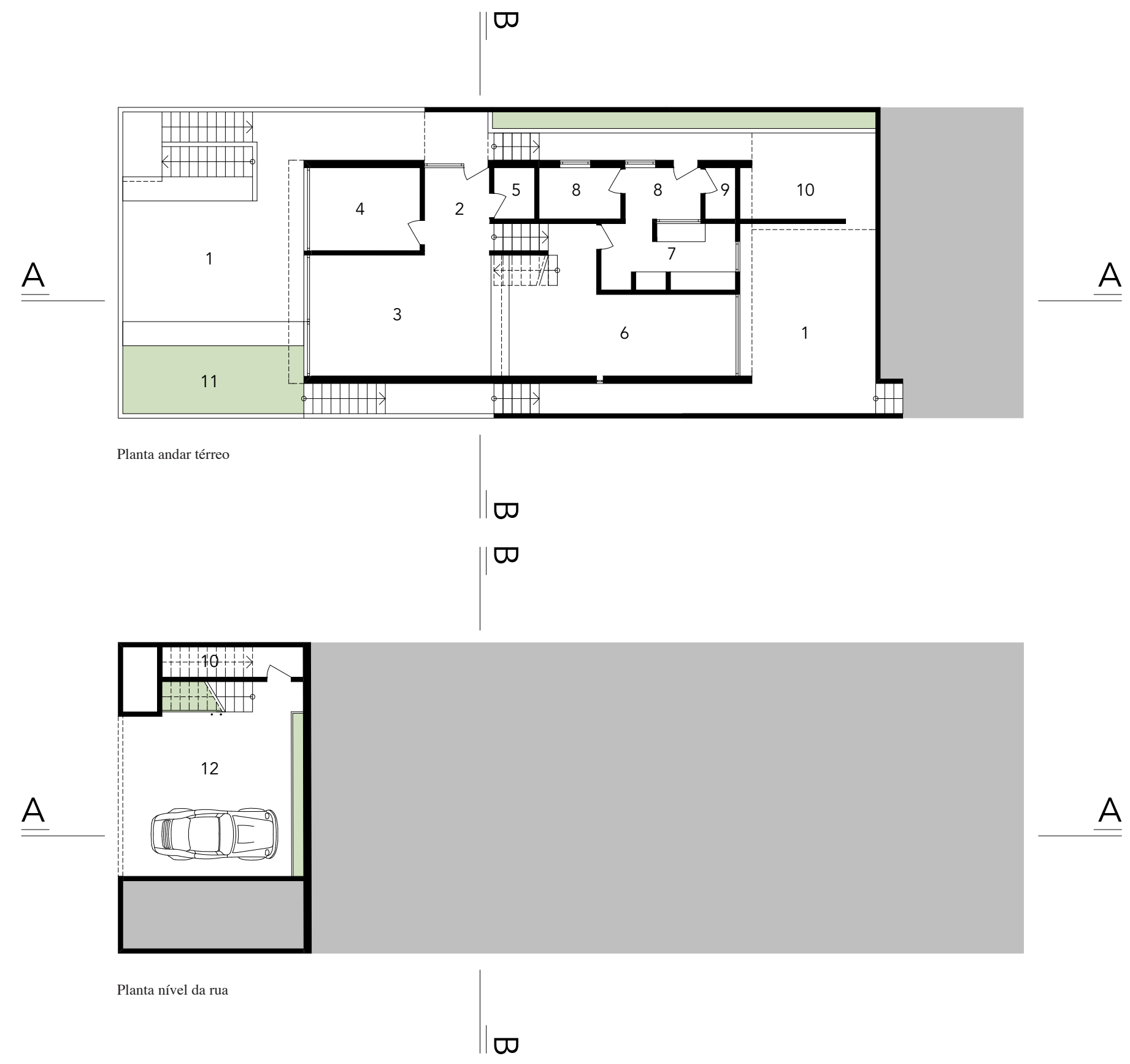




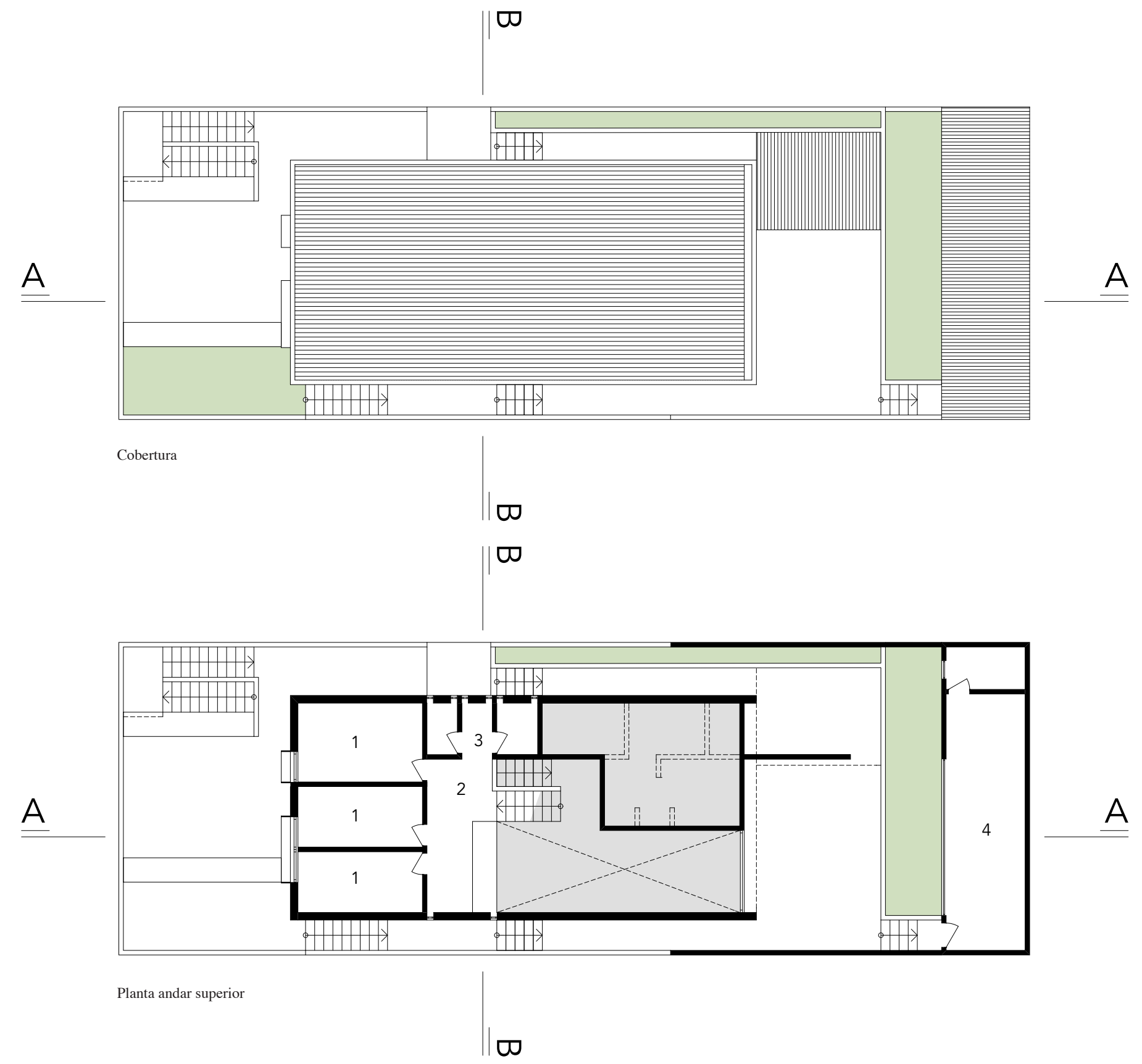

1. Dormitório

2. Estúdio

3. Banheiro

4. Visita/Suite A

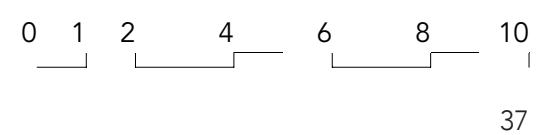



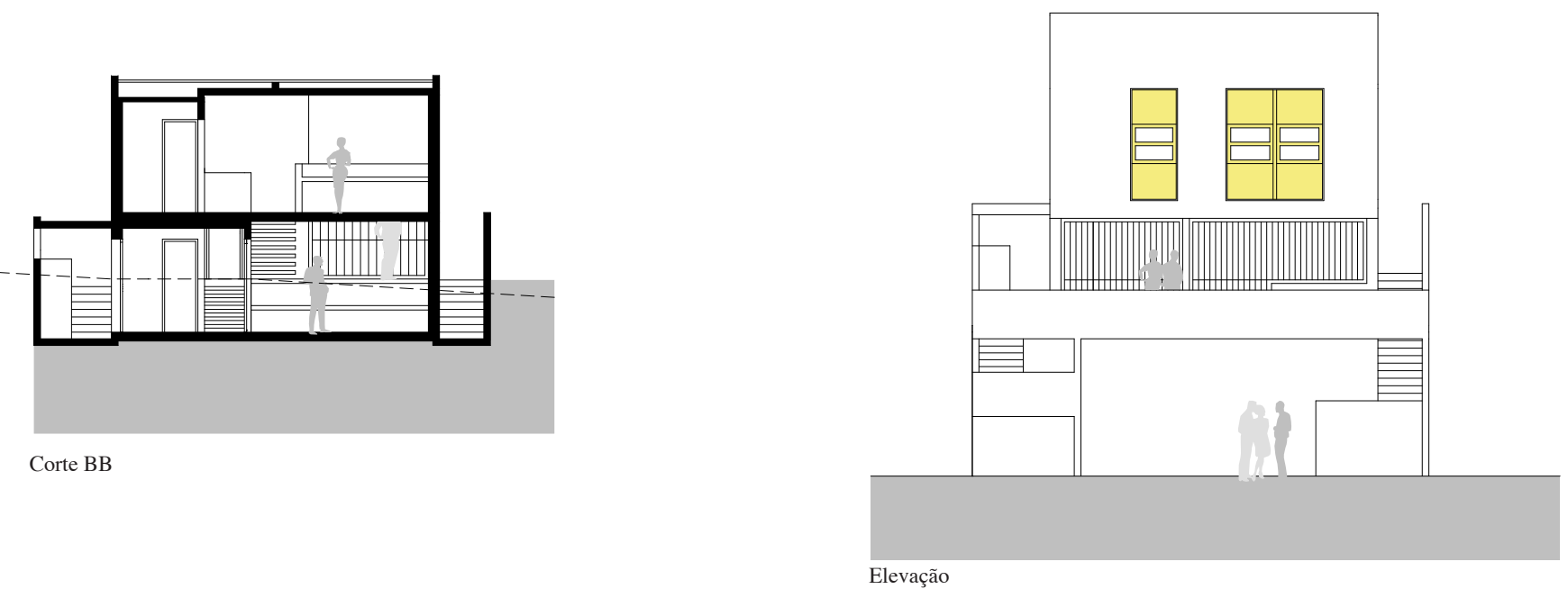
012 4 $8 \quad 10$

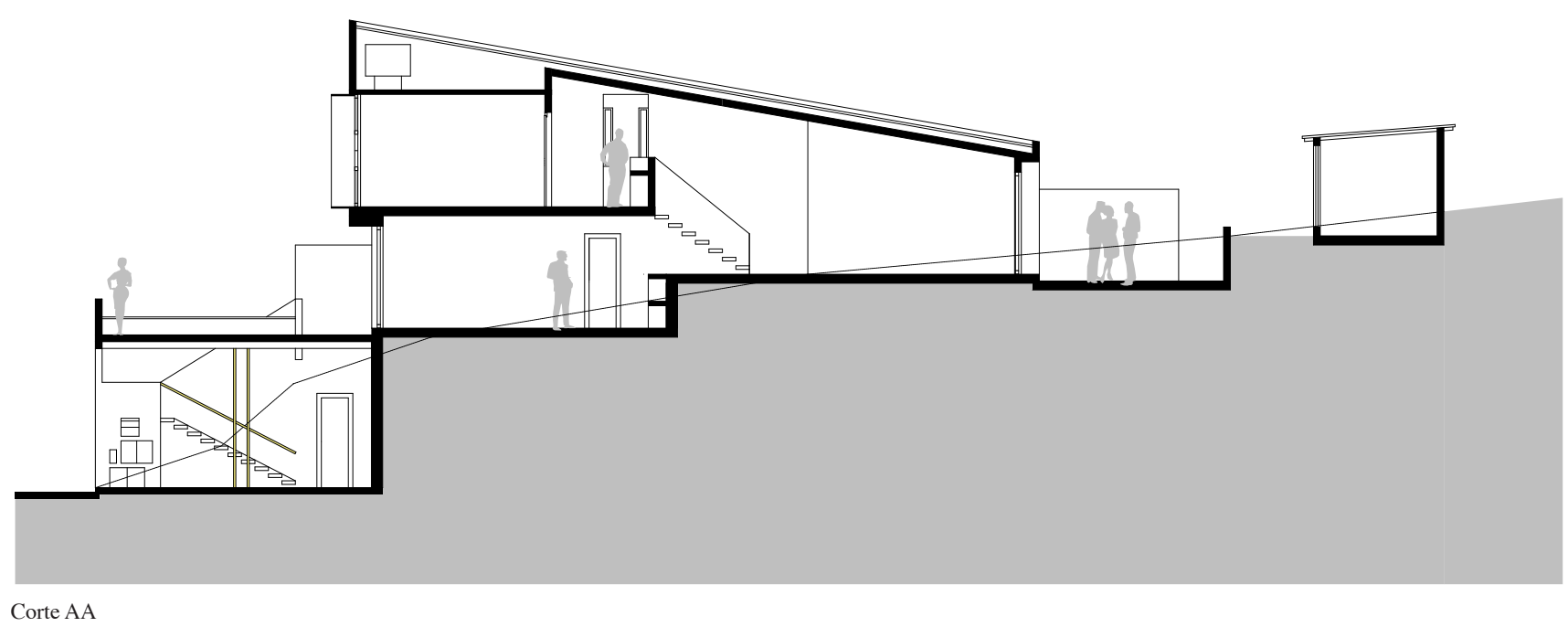



Inlin:

[Recorte 1973 - 1979]
EMURB - Empresa Municipal de Urbanização

[Recorte 1970 - 1973]

निये

[Recorte 1967 - 1970]

[Recorte 1963-1967]

FECE - Fundo Estadual de Construções Escolares

[Recorte 1961 - 1990]

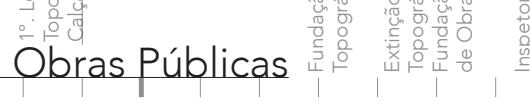

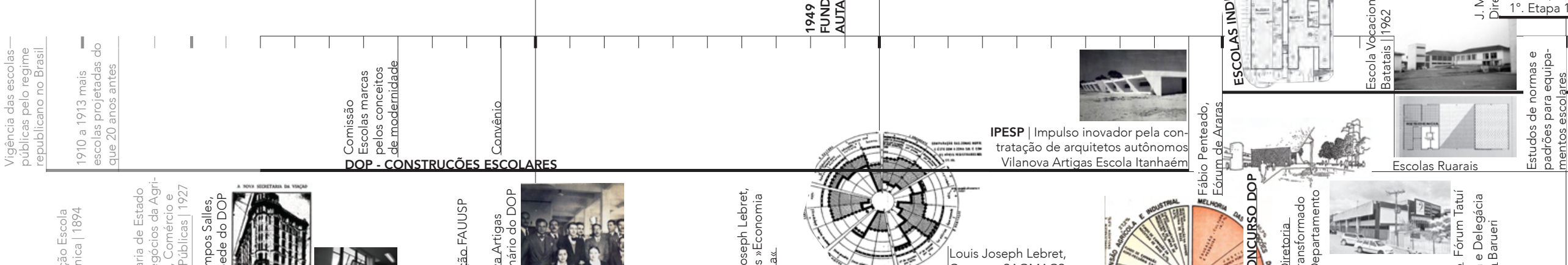





\section{INTRODUÇÃO - PROJETOS DO ARQUITETO AUTÔNOMO}

\section{LISTA DE PROJETOS}

Projeto de Residência

Expo-92, Sevilha, Espanha

Projeto de Residência

Projeto de Residência

Projeto de Residência

Projeto de Residência

Projeto Escola Estadual

Projeto de Residência

Projeto de Residência

Projeto de Edifício

Projeto de Residência

Projeto de Residência

Projeto de Edifício

(Apartamentos/Comercial

Projeto de Edifício

(Apartamentos)
Granja Viana, Cotia, SP 1992

Projeto do Pavilhão do Brasil 1992

Rua Piassanguaba, ^100, Planalto Paulista 1980

Rua 2, Lote 5, Quadra 5, Jardim Regina - Brotas 1980

Av. Manoel Ferro Rodriguez, lote 1, quadra 8, 1976

Jardim Guaiúba, Guarujá, SP

Rua João da Cruz Mellão, ${ }^{\circ} 221$, Jardim Leonor, SP 1972

Ginásio Estadual de Vila Brasilândia, Secretaria 1969

Educação do Governo do Estado de São Paulo

Vila Romana, São Paulo

1966

1966

1966

Escola Técnica Federal de São Paulo, Rua Júlio

M. Salgado, ${ }^{\circ} 234$, Barra Funda, SP

Rua Itacolomi, 32, Serra, Belo Horizonte, MG 1965

Rua Morato Coelho, ${ }^{\circ 50}$, Pinheiros 1964

Av. Rangel Pestana, 1522, Brás, São Paulo 1963

Condomínio Calíopena, Rua Peixoto Gomide, 1962

1554, Jardim Paulista, SP 
Projeto de Residência

Projeto de Residência

Projeto de Edifício

Projeto de Edifício

Projeto de Edifício (Apartamentos)

Projeto de Edifício (Apartamentos)

Projeto de Capela

Projeto de Edifício

Projeto de Residência
Rua Padre Vieira, 505, Bairro Jardim,

Santo André, SP

Rua dos Moraes, ${ }^{\circ} 237$, Pinheiros, SP

Hotel do Conjunto Turístico »Estância Termas

de Pompéia«, Socorro, SP

Rua Bahia, 88, Higienópolis, SP

Alameda Franca, Jardim Paulista, SP

Rua Navarro de Andrade, ${ }^{\circ} 20$, Pinheiros

Capela de São Teodoro, Vila Maria, SP

Edifício do Jornal »O Barnabé« em Brasília, DF

Rua Diamante, ${ }^{\circ} 108$, SP
1962

1962

1962

1962

1962

62

62

1961

1961

1960

1960 


\section{INTRODUÇÃO}

\section{BIBLIOGRAFIA}

Obras de referência do arquiteto Geraldo Vespaziano Puntoni: Acervo particular do arquiteto

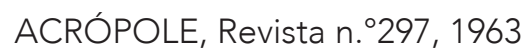

ARTIGAS, Vilanova. Instituto Lina Bo e P. M. Bardi, 1997.

BARDI, Lina. Lina por Escrito, Textos escolhidos de Lina Bo Bardi, Cosac e Naify.

BENJAMIN, Walter. Passagen, Suhrkamp, 1991.

BONDUKI, Nabil. Origens da habitação social no Brasil. São Paulo: 1994. Tese de doutorado apresentada na FAUUSP. São Paulo, Estação Liberdade/FAPESP, 1998.

BRUAND, Yves. Arquitetura contemporânea no Brasil. São Paulo, Perspectiva, 1981.
CULLEN, GORDON, Das Vokabular der Stadt, Birkhäuser, 1991.

COSTA, Lúcio. Lúcio Costa: registro de uma vivência. São Paulo: Empresa das Artes, 1995.

FERRO, Sérgio. O Canteiro e o Desenho, Vicente Wissenbach, 2005.

FLUSSER VÍLEM, Brasilien oder die Suche nach dem neuen Menschen, Bollmann, 1994.

FRAMPTON, Kenneth. Historia critica da arquitetura moderna. São Paulo, Martins Fontes, 1981.

KAMITA, João Masao. Vilanova Artigas. São Paulo: Cosac \& Naify Edições, 2000.

KOPP, Anatole. Quando o moderno não era um estilo, mas uma causa. São Paulo: Nobel, 1990.
LE CORBUSIER. (tradução: Carlos Eugênio Marcondes de Moura). Precisões sobre um estado

presente da arquitetura e do urbanismo. São Paulo: Cosac e Naify Edições, 2004.

MINDLIN, Henrique E. Arquitetura Moderna no Brasil. (Tradução Paulo Pereira) São Paulo: Aeroplano Editora/ IPHAN, 2000.

PISANI, Daniele. Paulo Mendes da Rocha - Obra Completa, 2G, 2013.

SANOVICZ, Abrahão. Sistematização Crítica da Obra de Arquitetura para Obtenção do Título de Livre Docente. São Paulo: FAUUSP, 1997. (Tese de Livre Docência)

SEGAWA, Hugo. Arquiteturas no Brasil 19001990. São Paulo: Edusp, 1999. 
Quem sou eu:

Quem sou eu?

ora! Eu sou eu!

Não sou cara nem coroa

Nem pistilo ou gineceu

Nem criada nem patroa.

Eu, ora! Eu sou eu.

RITA MOREIRA 


\section{[O ARQUITETO \& O ESTADO]}

CAPÍTULO 1 | RECORTE 1961 - 1990
Este capítulo pretende apresentar e analisar de forma sucinta a origem histórica do Departamento de Obras Públicas (DOP). A sua história tem uma importância na constituição do país que é relevante para a contextualização dos capítulos a seguir. O DOP é o fio condutor da carreira do funcionário público Geraldo Vespaziano Puntoni, que permaneceu trabalhando nesse órgão de 1961 a 1990, até ser comissionado pelo DOP para outros órgãos e companhias do estado. Este capítulo pretende levantar a importância desse órgão público, contextualizando os caminhos do arquiteto durante o período em que fez parte do DOP.

\section{A HISTÓRIA DO DOP}

O primeiro Plano Diretor da Cidade surgiu em 1792 através do primeiro levantamento topográfico da cidade, feito por engenheiros de estradas e topógrafos. Em 1835, devido ao processo de ocupação no interior do território paulista (causado pela cultura do café), foi criado o Gabinete Topográfico. A necessidade de abrir estradas de ferro por toda província foi uma das caraterísticas dessa primeira etapa de apropriação do território paulista. Essa caraterística é importante para a compreensão da influência da engenharia no DOP durante sua fase inicial. Ainda no Brasil Império, em 1844, foi criada a Diretoria de Obras Públicas (DOP) através da lei $n^{\circ} 253$, que lhe conferia atribuições amplas, aliadas às responsabilidades de executar todas as obras públicas, incluindo estradas, barcos, canais, fixações de limites intermunicipais e interprovinciais. Esta lei foi regulamentada em 1845 e sua existência foi efêmera, pois já em 1847 era a recém criada Diretoria extinta, passando as suas funções para a Escola do Gabinete Topográfico, precursora ensino de engenharia em São Paulo e viria a futura Escola Politécnica (1894) a partir do final do século XIX.
IMAGEM 28. Poesia da Rita Moreira. Achado em uma pasta no arquivo Ś́lvio Breno, com desenhos do Geraldo Vespaziano Puntoni. 
A NOVA SECRETARIA DA VIAÇAO

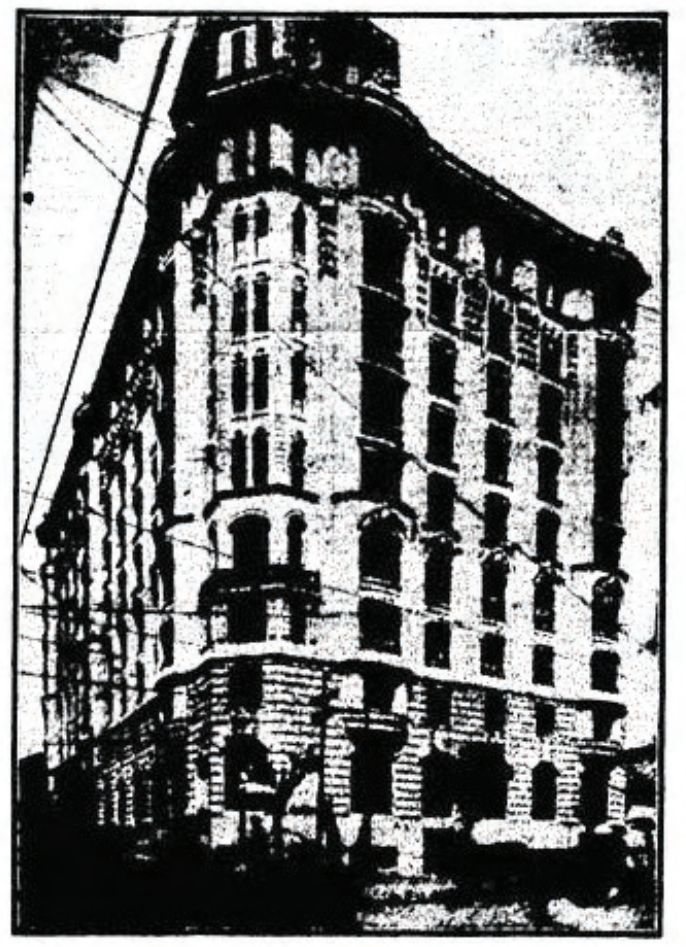

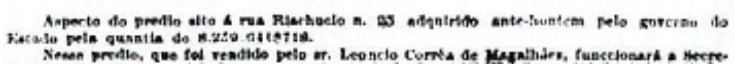

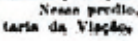

Somente em 1870, com a criação da Inspetoria Geral de Obras Públicas, a situação foi corrigida. Esses órgãos surgiram em um momento em que a província começou a passar por grande mudanças. A expansão da cidade de São Paulo e o crescimento de diversas outras cidades ao longo da estrada de ferro, foi consequência de um grande incremento ocorrido na economia cafeeira exportadora, que na primeira metade do século XIX, penetrou no Vale do Paraíba vindo do Rio de Janeiro - e a partir de 1860 iniciou sua marcha em direção ao oeste paulista. Dessa forma, a partir de 1870, a cidade de São Paulo passou a ser o ponto de convergência de todo o sistema ferroviário da província. A capital se transformou em um centro de negócios e de moradia da aristocracia cafeeira que, a partir desse momento, passa também a reverter parte de seus capitais em atividades urbanas, tais como especulação imobiliária e a indústria.

IMAGEM 29. EDIFÍCIO CAMPOS SALLES, 1928-1930, A NOVA SECRETARIA DA VIAÇÃO, Fonte: Jornal O Estado de São Paulo, Sexta-Feira, 4 de Abril de 1930, Aspecto do prédio alto, rua Riachuelo no. 115 adquirido ante-ontem pelo governo do Estado pela quantia de 8239.6418718, Nesse predio, que foi vendido pelo Sr. Leoncio Corréa de Magalhães, funcionará a Secretaria da Viação
Após 56 anos de existência, com a formação da Secretaria dos Negócios da Agricultura, Comércio e Obras Públicas, através da lei n. ${ }^{\circ} 2.103$ de
192, foi extinta a Inspetoria de Obras Públicas e criada a Diretoria de Obras Públicas. Segundo essa lei, todas as obras públicas do Estado continuavam sob a responsabilidade do DOP. Um ano depois, em 1927, foi criada a Secretaria da Viação e Obras Públicas, novo órgão administrativo, responsável por todos os encargos relativos a obras públicas do Estado; vinculado a esse novo órgão estava a Diretoria de Obras Públicas.

A lei que criou a nova Secretaria incluía em suas especificações a reorganização e fins da Diretoria de Obras Públicas. Eram então seus objetivos todos os assuntos referentes a engenharia e obras públicas do Estado. Em 1936, por força da homologação do decreto n. ${ }^{\circ}$ 8.053, que regulamentava a execução de obras do Estado, definiu-se de maneira mais precisa os encargos do DOP. Em 1962, obedecendo a lei n. ${ }^{\circ}$ 7.193, o DOP, então Diretoria, transformou-se em Departamento de Obras Públicas e, em 1966, através lei n. ${ }^{\circ} 9.296$, foi transformado em autarquia. Finalmente, em 1970, com a homologação da lei n. ${ }^{\circ}$ 52.520, de 26 de agosto de 1970, apro- 
vou-se o novo regulamento para a autarquia, mudando sua denominação para Departamento de Edifícios e Obras Públicas - DOP.

Durante o longo período de existência do DOP, passaram por ele nomes consagrados da Arquitetura e Engenharia Nacional, como Euclides da Cunha, André Rebouças, Theodoro Sampaio, Prestes Maia, Lucas Nogueira Garcez e, durante a década de 30, Vilanova Artigas.

»Wilson Rodrigues de Morais e Ruy Gama trabalharam no DOP. Artigas foi funcionário do DOP também. Por sinal, o caixilho da FAU USP é o mesmo do que no pátio interno do Ministério Público do Estado de São Paulo na Rua Riachuelo, 115, que era antigamente o Edifício da Secretaria de Viação e Obras Públicas. Artigas chupou direitinho, para desenhar os caixilhos da FAU USP."

É interessante ressaltar que Vilanova Artigas, uma das figuras mais importantes da »Escola

\footnotetext{
1 Entrevista, Geraldo Vespaziano Puntoni, 26.02.2014
}

Paulista ${ }^{2}$, amadureceu dentro do DOP, logo depois da sua formação em 1938. O caixilho do Edifício Campos Salles é realmente um detalhe pequeno, e seu desenho provavelmente não é de autoria do DOP, mas do escritório de Engenheiros \& Construtores Siciliano e Silva. Mesmo assim, a contribuição de Artigas com esse detalhe, e sua apuração três décadas depois na construção do Edifício FAU USP, revela a sensibilidade do arquiteto. A observação e valorização desses detalhes foram altamente reconhecidas e discutidas pelos engenheiros e arquitetos do DOP. Artigas, por sua vez, carregou essa bagagem em sua memória e transformou o caixilho da antiga sede do DOP em um detalhe que confirma a ideia arquitetônica do edifício da FAU USP onde os limites entre dentro e fora são »correntes».

2 A diferenciação entre a arquitetura paulista - de São Paulo - e a carioca aparece em: HITCHCOCK, Henry Russell. Op. cit, p. 36. Para uma outra genealogia da identidade paulista ver também: ZEIN, Ruth Verde. Breve introdução à arquitetura da Escola Paulista Brutalista. Arquitextos, São Paulo, ano 06, n. 069.01, Vitruvius, fev. 2006

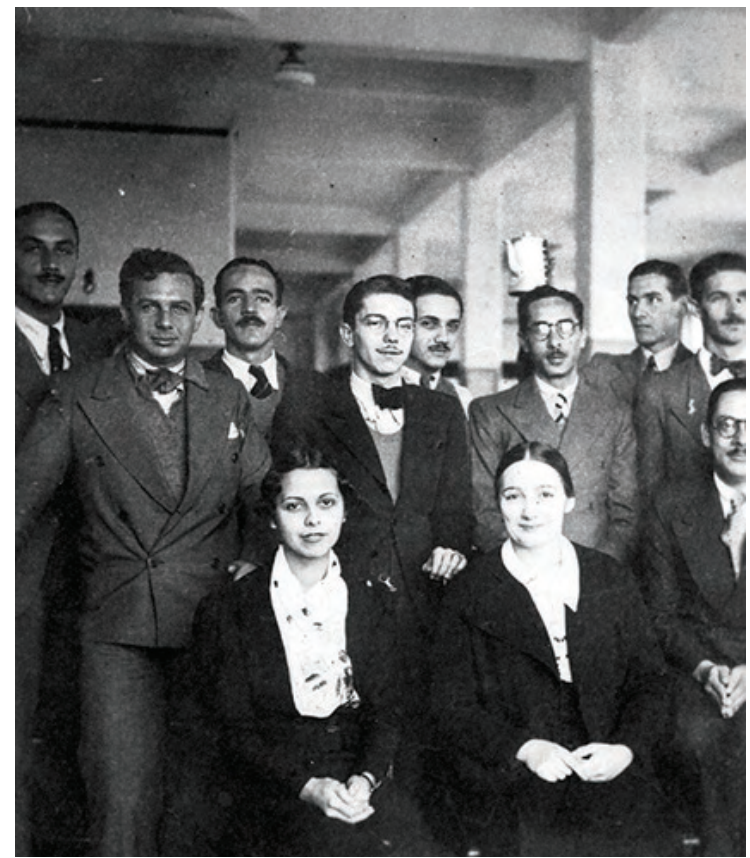

IMAGEM 30. ARTIGAS, Vilanova, trabalha no escritório técnico do Departamento de Obras Públicas (DOP). Fonte: http://vilanovaartigas.com/ cronologia/periodos/1938 

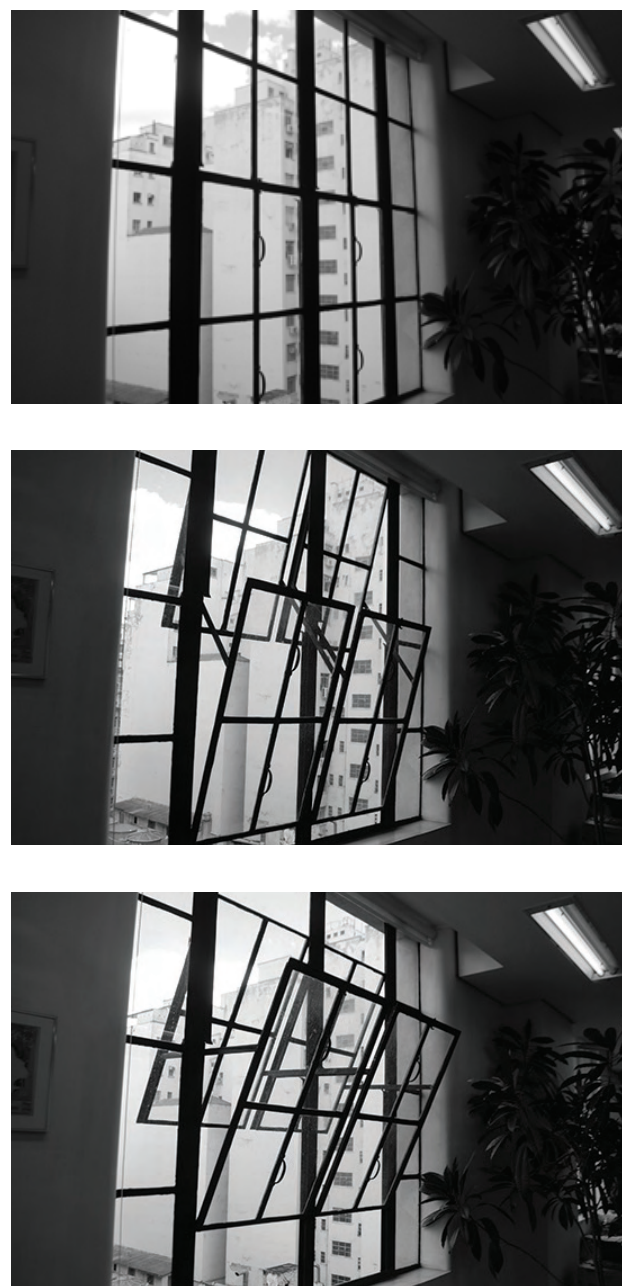

IMAGEM 31. Sequencia de fotos, Caixilho, Ed. Campos Salles, antiga sede do Departamento de Viação e Obras Públicas (DOP), Engenheiros \& Construtores Siciliano e Silva, Rua Riachuelo, 115, São Paulo. Fonte: Sebastian F. Beck

50
"A janela da FAU não é propriamente encaixilhada, pois não tem o usual quadro rígido e fixo formado pelos batentes superior e inferior que formam uma peça única fixada na construção, a qual, por sua vez, recebe os quadros móveis, que permitem a abertura do vão. Sua fixação é somente pelos montantes verticais. Como o movimento de abertura é vertical, os quadros batem, em cima, diretamente na laje [...]. Na FAU, quando a janela está aberta, a laje fica livre, propiciando uma maior integração dentro e fora $[\ldots] .^{3}$
Esse discurso sobre Artigas e sua vivência no DOP é interessante para entender melhor esse departamento pouco conhecido e sua importância para arquitetos e engenheiros consagrados no Brasil. Os caminhos entre o DOP, Vilanova Artigas e Geraldo Vespaziano Puntoni entrelaçaram-se novamente através do Plano de Ação Carvalho Pinto e a construção das Escolas para o IPESP em 1961. Antes de uma breve introdução sobre o Plano de Ação Governo Carvalho Pinto é importante esboçar a influen-

3 BAROSSI, Antonio Carlos. O edifício da FAU- USP de Vilanova Artigas, p.70, Editora da Cidade, São Paulo, 2016.
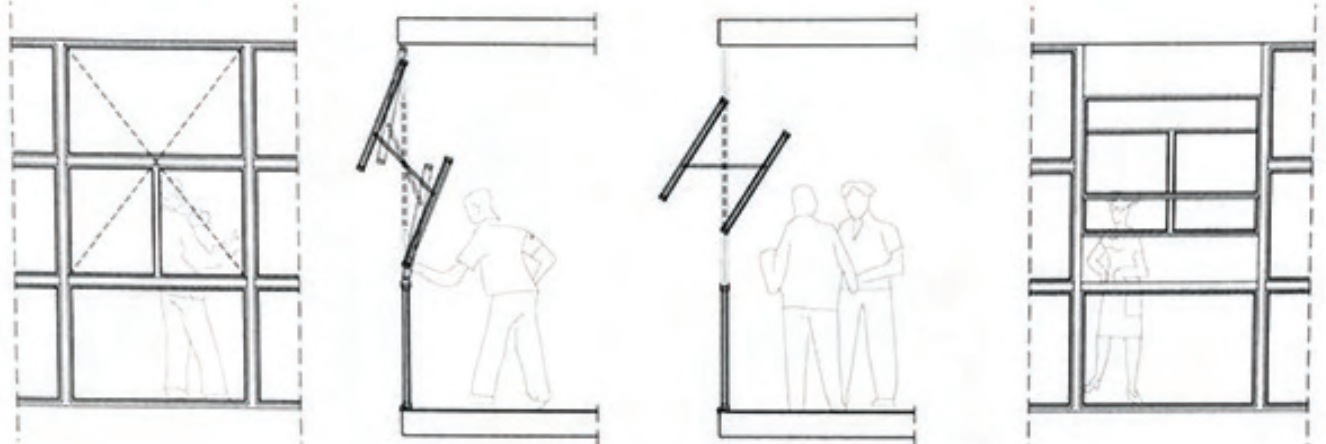

IMAGEM 32. Desenhos caixilhos da FAU USP, Fonte: O edifício da FAUUSP de Vilanova Artigas, Antonio Carlos Barossi, p.70, Editora da Cidade, São Paulo, 2016. 
cia do Padre Louis-Joseph Lebret ${ }^{4}$ para a reformulação do Departamento das Obras Públicas.

\section{Louis Joseph Lebret - Por uma Civiliza- ção Solidária}

O Padre Lebret veio a São Paulo em 1947. Nesta data, a escola de Sociologia Política organizou um curso de atualidades econômicas e políticas, no qual estiveram presentes pessoas na sua maioria ligadas à ação católica e aos dominicanos, com o interesse de conhecer a nova doutrina chamada »Economia Humana«. ${ }^{5}$ Com a motivação deste evento surgiu o Movimento

4 Louis-Joseph Lebret nasceu em Saint Malo, na Bretanha, França, em 26/06/1897 e faleceu em Paris em 20/07/1966, com 69 anos. Nasceu em uma família de forte tradição naval, ingressou na Marinha aos 15 anos como aprendiz de marinheiro, depois estudou na Escola Naval de Brest, formou-se oficial de marinha francesa, onde teve oportunidade de conhecer vários lugares do mundo. Deixou a marinha em ministrar um curso de alguns meses na Escola de Sociologia e Política de São Paulo sobre "Economia e Humanismo" atualidades econômicas e Políticas, no qual participaram várias personalidades de vários locais do país.

5 LEBRET, Louis Joseph. Manifesto por uma civilização solidária, 1957 , p.13. Definimos a economia humana, enquanto pesquisa, como a disciplina, especulativa e prática, da passagem, para uma determinada população, de uma fase menos humana para uma fase mais humana, segundo o ritmo mais rápido possível, com o custo financeiro e humano o menos elevado possível, sem esquecer a solidariedade que deve existir entre todas as populações. de Economia e Humanismo e foi criada a SAGMACS - Sociedade para Análise Gráfica e Mecanográfica Aplicada aos Complexos Sociais.

"[...] A gente já tinha antes do Plano de Ação do Governo Carvalho Pinto uma outra fase com Louis-Joseph Lebret. Um grande economista e religioso católico dominicano francês. Uma das coisas que se falava era »ver, julgar e agir". Que foi levada como uma especialidade do Padre Lebret. [...] O Padre Lebret tinha uma metodologia muito própria que ele criou para medir a qualidade de vida. Não era só economia, tinha várias dimensões que ele tentava medir. Ele levava a gente para fazer uma investigação de campo. ${ }^{6}$

» [...]Padre Lebret dizia, que o desenvolvimento não é econômico, o desenvolvimento precisa ser social, senão, não adianta nada. Ele foi o primeiro a fazer a pesquisa: Como calcular o nível de vida das pessoas? Ele fez isto com gráficos, por isso o SAGMACS (Análises Gráficas e Mecanográficas),

6 Entrevista, Domingos Teodoro de Azevedo Marques, 26.05.2014

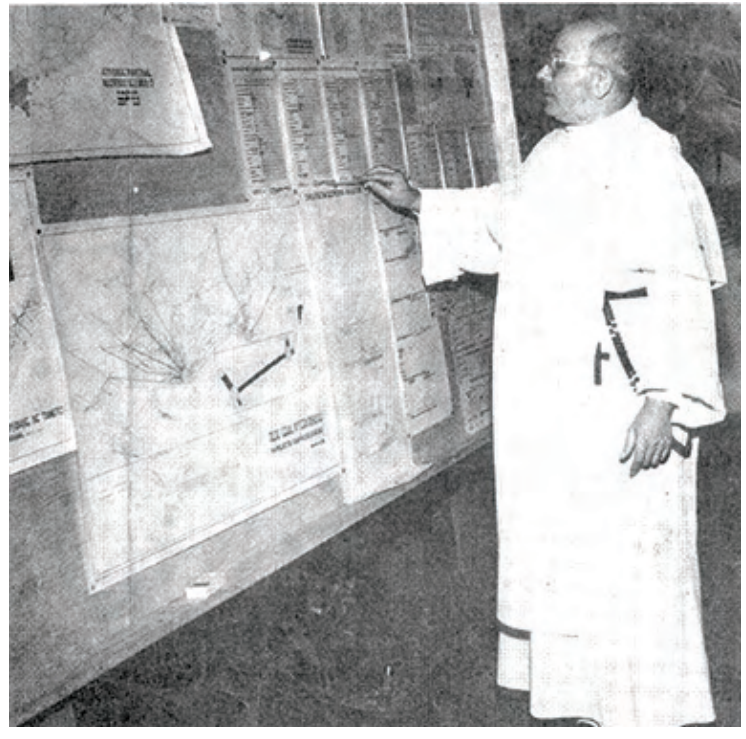

IMAGEM 33. Padre Louis-Joseph Lebret apresentando o Plano "Aglomeração Paulistana” em São Paulo. Fonte: Jornal Folha da Manhã, em $05 / 03 / 1958$ 


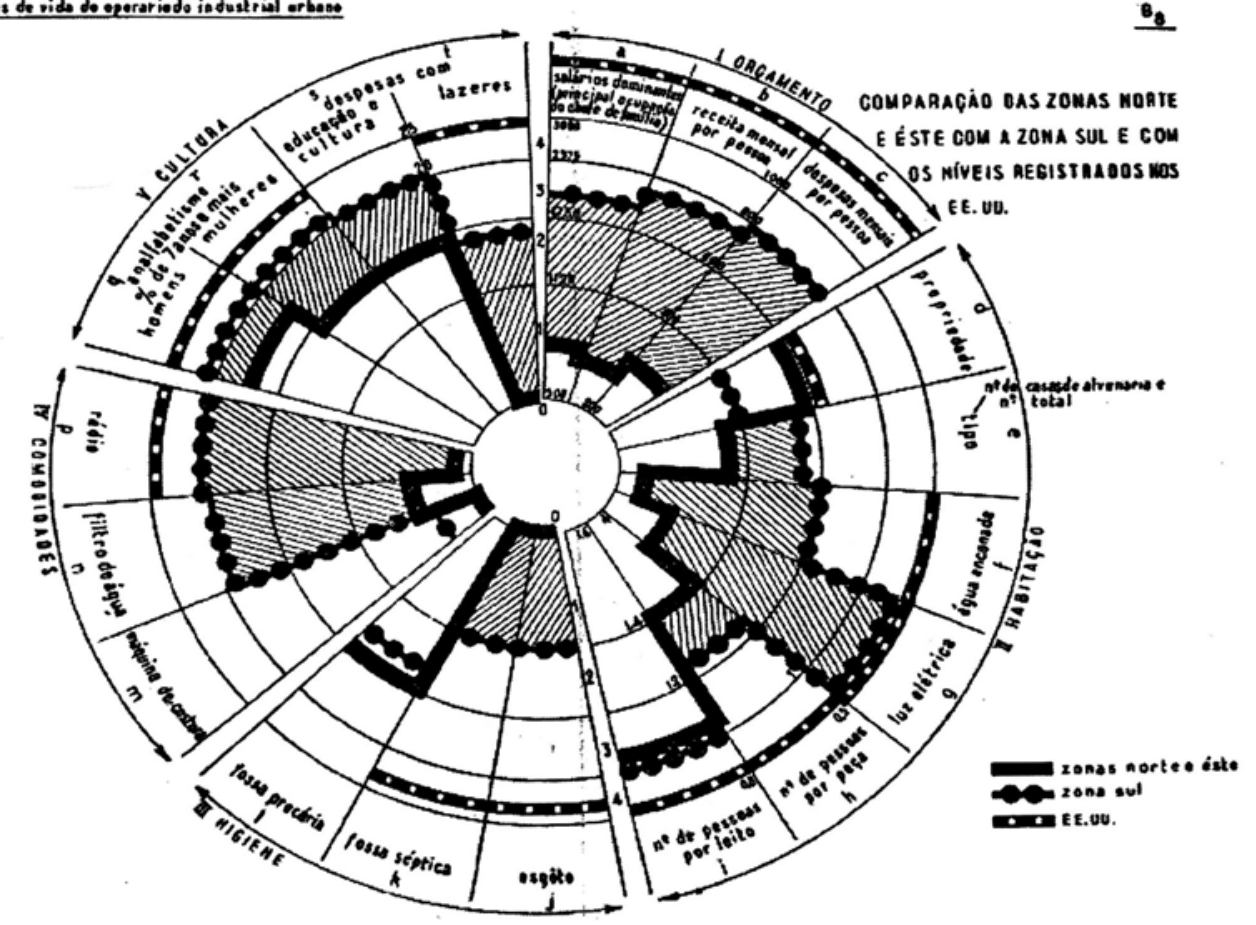

e depois desenvolveu os desenhos que mostraram o retrato da população. «T

O SAGMACS desenvolveu inúmeros trabalhos em diversos estados no Brasil, levantando questões fundamentais da época e buscando novos caminhos rumo a desenvolvimento econômico dentro do quadro da teoria da Economia e Humanismo. A pesquisa começou a partir da elaboração de novas formas de pensar os problemas

IMAGEM 34. Gráfico comparativo dos níveis de vida entre o nordeste região centro sul e os EUA. Fonte: LEBRET, L.J. Estudo sobre desenvolvimento e implantação de indústrias, 1955.

52

7 Entrevista, Clementina Delfina de Ambrosis, 26.05.2014 das cidades, levantando dados de forma empírica e prognósticos através do bem estar social da população. Esses dados foram comparados sob o ponto de vista das condições urbanas.

Quando Padre Lebret voltou pela segunda vez ao Brasil, entre 1952 e 1956, a sua vinda foi marcada pelo contrato entre SAGMACS e a »Comissão Interestadual da Bacia Paraná/Uruguai«, um convênio entre os Estados banhados pelos rios Paraná e Uruguai: Paraná, Minas Gerais, São Paulo, Mato Grosso, Santa Catarina e Rio Grande do Sul.

"Havia também no Estado de São Paulo uma Comissão Interestadual da Bacia ParanáUruguai. Quem mandava nessa coisa era o pai do “Paulinho” (Paulo Mendes da Rocha). Nome do Pai era Paulo Menezes Mendes da Rocha. Ele preparou todos os estudos preliminares para a bacia dos rios Tietê e Paraná. Todas as usinas foram feitas com base nos estudos de Paulo Menezes Mendes da Rocha, que tinha providenciou tudo com antecedência. $\ll^{5}$ 
Durante a segunda vinda de Padre Lebret, Clementina Ambrosis e Domingos Teodoro trabaIharam em sua equipe. Paulo Menezes Mendes da Rocha coordenava o projeto da Bacia Paraná-Uruguai e o contrato feio pelo SAGMACS, foi com a Comissão Interestadual da Bacia Paraná-Uruguai.

Haviam diversos políticos envolvidos no SAGMACS, tanto que mais tarde alguns se tornaram governadores ou políticos como no caso do Teófilo Ribeiro de Andrade (1922-2015) um dos fundadores do Partido Democrata Cristão - PDC.

»Eu estava muito perto dessa turma. De um lado Plínio Sampaio, ligado ao Carvalho Pinto e do outro lado Teófilo Ribeiro de Andrade, um dos fundadores do PDC. «

A influência de Padre Lebret nas décadas de 1950 e 1960 no Brasil representou um ponto de inflexão, uma mudança na maneira de projetar, planejar e resolver os problemas urbanísticos das cidades. Essas exigências também reba- teram no funcionamento dos órgãos públicos, uma nova maneira de "pensar« significava também uma nova organização no procedimento de »trabalhar«. O DOP, até então, funcionava em setores separados, com procedimentos antigos. Os projetos foram desenvolvidos isoladamente, sem muita noção do conjunto, uma vez que a ideia de interdisciplinaridade veio somente através de Padre Lebret e sua organização em forma de ateliês, onde o projeto podia circular integralmente entre as diversas disciplinas, como arquitetura, hidráulica, elétrica, etc. Talvez o impulso de Padre Lebret fosse necessário para iniciar uma reformulação no Departamento de Obras Públicas, que cedeu com o Governo do Carvalho Pinto e seu Plano de Ação.

Plano de Ação do Governo Carvalho Pinto - PAGE

Como ponto inicial da carreira do funcionário público Geraldo Vespaziano Puntoni, destaquese a época do Governo Juscelino Kubitschek, 

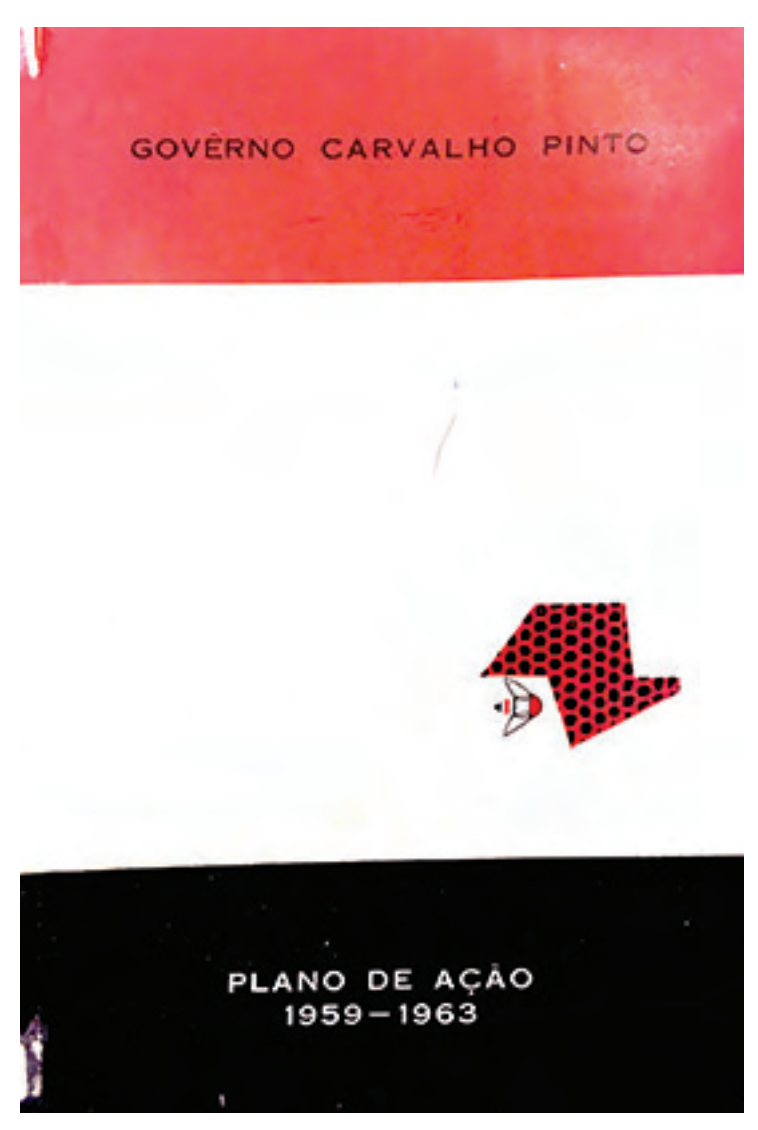

IMAGEM 35. Capa do Livro Plano de Ação do Governo Carvalho Pinto 1959 - 1963, Fonte: Biblioteca de Direito da USP.

54 de 1956 a 1961. O »Plano de Metas $«^{8}$ do Governo JK não passou despercebida no estado de São Paulo. Com a eleição do novo Governador Carvalho Pinto (1959 - 1963), o Departamento de Obras Públicas entrou em uma fase muito produtiva por conta do Plano de Ação Carvalho Pinto - PAGE. O plano insere-se em um momento, onde o Brasil buscava organizar uma base de desenvolvimento econômico social. Na época, - Plano de Metas era considerado uma grande referencia, portanto o PAGE pode ser entendido como uma representação da modernização do caráter estadual que teria um vínculo nacional. A carreira do funcionário público Geraldo Vespaziano Puntoni começou exatamente nesse momento dinâmico. Em 1961, através de um concurso público, Geraldo Vespaziano Puntoni entrou como funcionário público no DOP.

8 O Plano de Metas foi um importante programa de industrialização e modernização levado a cabo na presidência de Juscelino Kubitschek. O Plano foi um conjunto de diversos objetivos setoriais para enfrentar as importações que vinham desenrolando os dois decênios anteriores.
»No governo Carvalho Pinto, havia o Plano de Ação. Na época mudou o procedimento federal de recursos para transferir o dinheiro. Carvalho Pinto e Plínio de Arruda Sampaio, que era o assessor dele, resolveram fazer um Plano de Ação (PAGE). ${ }^{9}$

O Plano de Ação tinha dois objetivos principais: conseguir investimentos para a melhoria das condições do homem e para a promoção do desenvolvimento. O PAGE buscava um desenvolvimento econômico e social harmônico, promovendo de um lado o desenvolvimento das regiões rurais do interior do estado, que foram marcadas de um atraso de infraestrutura e equipamentos sociais, e por outro, incrementando as ideias humanísticas do Padre Lebret.

"Quando Carvalho Pinto entrou como Governador, já existia todo esse trabalho (SAGMACS) sobre o Estado de São Paulo. Depois foi feito um trabalho semelhante para o estado Paraná, Santa Catharina e Rio Grande do Sul. Deixou-se Matogrosso e Goiás porque eram estados inacessíveis. ${ }^{6}$ 
É evidente que Carvalho Pinto aproveitou os dos estudos do SAGMACS e, de certo modo, dos fundamentos ideológicos do dominicano Padre Lebret. O DOP era um órgão que produzia e era composto por funcionários que já trabalharam com Padre Lebret. Assim, o DOP ganhou a responsabilidade, bem no sentido »Lebreiano« de »ver, julgar e agir $\aleph^{6}$. Consequentemente, o Governo Carvalho Pinto ampliou os setores de arquitetura e engenharia no DOP e criou novas vagas para arquitetos e engenheiros jovens, comprometidos com a arquitetura moderna brasileira.

»O DOP era algo que construía, ampliou o seu quadro de arquitetos e eu consegui entrar. «"

Com a coordenação de Plínio de Arruda Sampaio, se formou um grupo de planejamento, encarregado em especificar as diretrizes do PAGE, acompanhar sua execução e proceder sua revisão anual. Faziam Parte do Grupo de Planejamento Diogo Adolpho Nunes Gaspar, econo-

9 Entrevista, Geraldo Vespaziano Puntoni, 26.02.2014 mista e Secretário Executivo; Celeste Ângela de Souza de Andrade, Diretora do Departamento de Estatística; Ruy Aguiar da Silva Leme, Professor Catedrático da Escola Politécnica da USP; Antônio Delphim Netto, Assistente da Faculdade de Ciências Econômicas e Administrativas da USP; Sebastião Advíncula da Cunha, do Departamento Econômico do BNDE; Orestes Gonçalves, Chefe do Gabinete dos Estudos Econômicos e Financeiros da Secretaria da Fazenda; Ruy Miller Paiva, Engenheiro Agrônomo do Departamento da Produção Vegetal da Secretaria da Agricultura; e Paulo Menezes Mendes da Rocha, Professor Catedrático da Escola Politécnica da USP e coordenador do projeto da Bacia Paraná-Uruguai, citado anteriormente. Subordinado a esse Grupo de Planejamento estava a equipe técnica do PAGE, formada por especialistas que coordenavam as ações com as Secretarias. Essa equipe foi composta pelos arquitetos: Francisco Whitaker, Celso Lamparelli e Domingos Theodoro; pelos engenheiros Mário Laranjeira e Henrique Silveira; pelo administrador Antônio Amílcar; pelo contador José Rey-

\section{PLANO DE AÇĀO DO GOVÊRNO}

DISTRIBUIÇĀO SETORIAL DOS INVESTIMENTOS

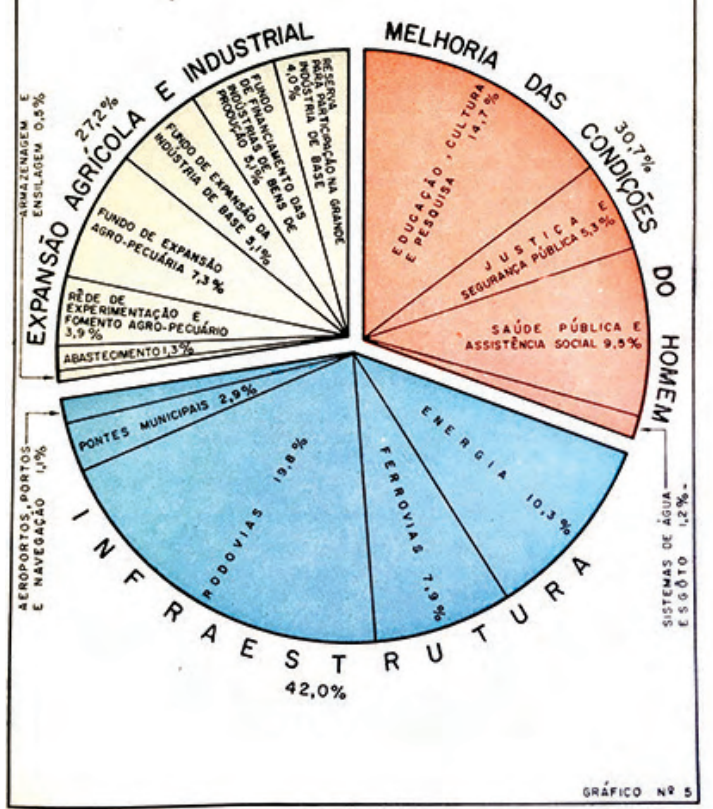

IMAGEM 36. PLANO DE AÇÃO DO GOVERNO, distribuição setorial dos investimentos, Fonte: Livro, Govêrno Carvalho Pinto, Plano de Ação 1959-1963, gráfico n5 
naldo e por Pedro Penteado com atribuições específicas. Domingos Teodoro de Azevedo Netto foi entrevistado para essa pesquisa e ele confirmou a composição da equipe:

»Diogo Adolpho Nunes Gaspar, economista, foi convidado para comandar o Plano de Ação e ele aceitou. Estava organizado assim: Haviam dois grupos, os Técnicos - do qual fazíamos parte e um grupo que dava a orientação - economistas e professores. Esse pessoal se encontrava uma vez no mês. No fim de cada ano fazíamos uma publicação, um balanço do que tinha sido feito e o que faltava para fazer. Eu tenho cinco volumes do Plano de Ação, eles devem estar na FAU Maranhão. ${ }^{6}$

Através do PAGE, foram construidos serviços básicos para infraestrutura, como ferrovias, rodovias e pontes. Isso foi a maior parte do investimento, com $42 \%$ do PAGE, além disso foram investidos 27,2\% na expansão agrícola e industrial, e estavam previstos $30,7 \%$ para o desenvolvimento dos equipamentos da sociedade, com uma série de edifícios públicos para segurança, educação e saúde, conformando assim uma rede de serviços públicos em diversos municípios.

»Do ponto de vista politico era necessário construir escolas, hospitais, postos de saúde e fóruns. Então, Plínio Sampaio queria negociar. Havia um planejamento e os prefeitos chegaram como se fossem uma fonte luminosa, queriam convencer Plinio Sampaio a construir tal coisa, em tal cidade. Mas Plínio sabia o que tinha em tal lugar e ele escolhia através do plano que foi muito amarrado e muito eficiente. Na época se construía muito, muito mesmo! A gente tinha um mapa do tamanha dessa sala, de todo o estado de São Paulo, indicando onde estavam as obras. E as obras eram feitas pelo DOP. « ${ }^{6}$

A linguagem arquitetônica moderna, durante - PAGE, era senso comum entre os funcionários do DOP. O PAGE proporcionou para muitos jovens arquitetos a possibilidade de cultivar as ideias da nova arquitetura, como novos conceitos espaciais, que potencializavam novas práticas sociais. O PAGE destacou-se como um 
PLANO DE AÇÃO DO GOVERNO DISTRIBUIÇAO SETORIAL DOS INVESTIMENTOS

(Em milhões de cruzeiros)

\begin{tabular}{|c|c|c|c|c|c|}
\hline SETORES & Total & 1959 & 1960 & 1961 & 1962 \\
\hline \multirow{6}{*}{ 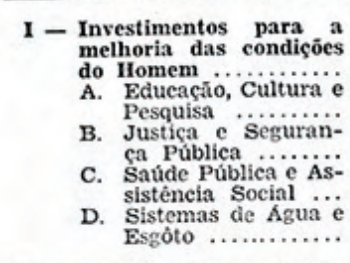 } & & & & & \\
\hline & 30.725 & 2.777 & 7.904 & 9.206 & 10.838 \\
\hline & 14.682 & 824 & 3.777 & 4.535 & 5.546 \\
\hline & 5.325 & 898 & 1.332 & 1.452 & 1.643 \\
\hline & 9.518 & 935 & 2.430 & 2.829 & 3.324 \\
\hline & 1.200 & 120 & 365 & 390 & 325 \\
\hline II - Investimentos de infra- & 41.954 & 4.654 & 10.545 & 11.962 & 14.793 \\
\hline \multirow{3}{*}{ 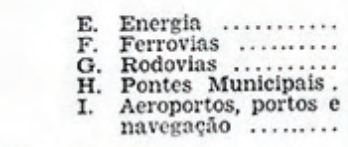 } & 10.254 & 2.566 & $\begin{array}{l}2.966 \\
1.950\end{array}$ & 2.038 & $\begin{array}{l}2.684 \\
3.320\end{array}$ \\
\hline & 19. & 1.3 & $\begin{array}{l}1.950 \\
4.480 \\
778\end{array}$ & $\begin{array}{l}6.500 \\
669\end{array}$ & $\begin{array}{l}7.560 \\
7.53\end{array}$ \\
\hline & & 118 & 371 & 355 & 256 \\
\hline \multirow{3}{*}{ 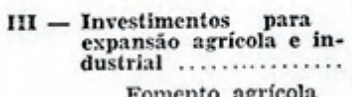 } & & & & & \\
\hline & 27.221 & 1.301 & 6.483 & 9.379 & 10.058 \\
\hline & & & & & \\
\hline $\begin{array}{l}\text { J. Armazenagem e en- } \\
\text { silagem } \\
\text { K. Abastecimento } \\
\text { L. Ré........... } \\
\text { Re experimen- }\end{array}$ & $\begin{array}{r}525 \\
1.250\end{array}$ & $\begin{array}{l}110 \\
230\end{array}$ & $\begin{array}{l}125 \\
280\end{array}$ & $\begin{array}{l}140 \\
320\end{array}$ & $\begin{array}{l}150 \\
420\end{array}$ \\
\hline \multirow{2}{*}{ 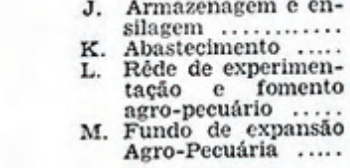 } & 3.946 & 461 & 1.078 & 1.119 & 1.288 \\
\hline & 7.250 & 250 & 2.000 & 2.500 & 2.500 \\
\hline \multirow{4}{*}{ 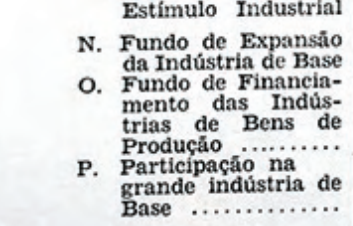 } & & & & & \\
\hline & 5.125 & 125 & 1.000 & 2.000 & 2.000 \\
\hline & 5.125 & 125 & 1.000 & 2.000 & 2.000 \\
\hline & 4.000 & - & 1.000 & 1.300 & 1.700 \\
\hline Total & $100.000^{*}$ & $8.832^{*}$ & 24.932 & 30.547 & 35.689 \\
\hline
\end{tabular}

Compreende participaçáo no aumento de Capital do Banco do Estado de Sáo Paulo S.A. momento singular na administração pública estadual no Brasil, efetuando e impulsionando a modernização do Estado de São Paulo. A arquitetura do PAGE, pelo respaldo da arquitetura moderna, levou para o interior do estado uma nova conformação espacial através dos seus projetos de uso público. Os projetos sugeriram novos temas, além de conceitos formais, como por exemplo a comunicação do espaço entre interior e exterior, permeabilidade, fluxos, e adequações climáticas. Como exemplo disso, temos o uso do muxarabi, além de questões construtivas e $\mathrm{o}$ uso de novos materiais. A verdade construtiva revela-se pela estrutura aparente. Plínio de Arruda Sampaio, amigo de vários arquitetos que fizeram parte das discussões do cenário cultural da época, teve um grande interesse em contratar projetos de arquitetos liberais fora da administração pública. No caso financiado pelo Instituto de Previdência do Estado de São Paulo.

IMAGEM 37. Tabela, Plano de Ação do Governo Carvalho Pinto. Investi-

mentos em melhoria do homem, infraestrutura e industria, p.11 

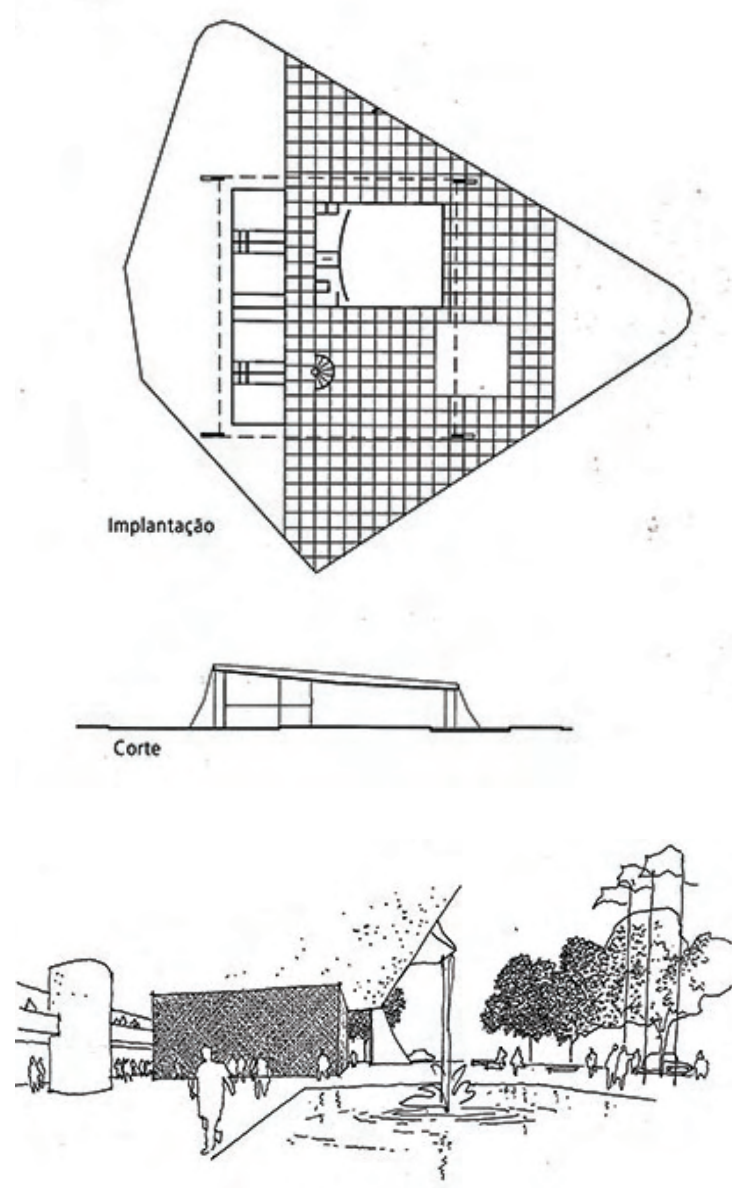

IMAGEM 38. PENTEADO, Fábio. Fórum de Araras, Ensaios de Arquitetura, Corte e Planta, p. 5

IMAGEM 39. PENTEADO, Fábio. Fórum de Araras, Ensaios de Arquitetura, Perspectiva, p. 57
"A participação de arquitetos que fossem profissionais liberais, ou de pequenos escritórios, portanto não pertencentes ao quadros do funcionalismo, como contratados para a confecção de projetos, deu-se não sem resistências do DOP. A decisão da contratação foi acordada após reuniões no Instituto dos Arquitetos do Brasil de São Paulo (IAB-SP) [...] realizado no dia 01 de dezembro de 1959 [...] «10

Esse acordo proporcionou grandes oportunidades de trabalho para a nova geração de arquitetos paulistanos. Um dos edifícios que evidencia a reinvenção dos ambientes e as novas condições para seus usuários era o Fórum de Araras (1960), projeto do arquiteto Fábio Penteado. Através da sua praça aberta, o Fórum é acessível a todas as camadas da sociedade.

Parte do Plano de Ação foi também a criação de diversos fundos, com objetivo de acelerar os processo de construção dos equipamentos

10 CORDIDO, Maria Tereza Regina Leme de Barros, Arquitetura Moderna: A Rede de Fóruns Modulares do Estado de São Paulo (1969-1975), Tese de Doutorado, p. 73. USP São Carlos, 2012. anunciados no PAGE. Um desses fundos era - Fundo Estadual de Construções Escolares.

Artigo $3^{\circ}$ - Dentro dos limites da autorização contida no artigo primeiro, fica igualmente o Poder Executivo autorizado a:

I - Criar os seguintes Fundos:

a) Fundo Estadual de Construções Escolares, para atender à construção, ampliação e equipamento de prédios destinados a escola de ensino primário e médio: ${ }^{11}$

O artigo da página oito do PAGE foi o início de um novo órgão, cuja história desdobrou-se até hoje e é conhecido como FDE - Fundação para - Desenvolvimento da Educação. O arquiteto Geraldo Vespazinano Puntoni pediu, depois de pouca permanência no DOP, a transferência para - FECE. O fundo, sua história e seu interesse em desenvolver projetos que atendam um bem comum serão discutidos no próximo capítulo.

11 PAGE - Plano de Ação do Governo Carvalho Pinto, p.8 
"Eu fiquei três, quatro meses no DOP Existia o Fundo Estadual de Construções Escolares (FECE) a Secretaria de Educação criou esse fundo e precisava de arquitetos. Daí eu fui para o FECE como funcionário do DOP, mas não deixei de ser funcionário do DOP. Comecei trabalhar no Departamento de Ensino Profissional para fazer projetos de novas Escolas Industriais. ${ }^{12}$

Mas antes disso, vale ressaltar as contribuições do DOP dentro do quadro dessa grande oficina de projetos e os problemas que surgiram ao longo do tempo. Enquanto o PAGE significou uma abertura no desenvolvimento de projetos dentro do DOP, mas também na integração de projetos de arquitetos autônomos através do IPESP, a Ditadura Militar significou um retrocesso para diretrizes anteriores ao PAGE. Como o DOP projetou anterior ao PAGE principalmente projetos padrões (estilo eclético) o departamento retomou essa atitude de padronização de projetos.

12 Entrevista, Geraldo Vespazinano Puntoni, 26.02.2014

\section{PADRONIZAÇÃO NO DOP}

Ponto inicial da padronização no DOP foi uma pesquisa com levantamentos de dados para poder elaborar um programa padrão, que teve como resultado a ideia de criar uma uniformidade nas condições materiais e espaciais. Consequentemente, foram desenvolvidos projetos executivos para hidráulica, elétrica, estrutura e arquitetura. Assim surgiram os primeiro projetos padronizados, como as delegacias e depois centros de saúde. A normatização dos procedimentos no sentido administrativo e técnico orientou a padronização arquitetônica.

»Você tinha um projeto e você transformava o projeto em uma leitura de quantificar [...] Quantos tijolos, quanto de argamassa, quanto de ferro - ler a planta e transformar isso em valores, quantidades, suprimento, mão de obra. [...] Quanto de mão de obra é gasta para $1 \mathrm{~m}^{2}$ de uma parede de tijolos? Todo mês havia uma apropriação de custo. $\ll^{13}$

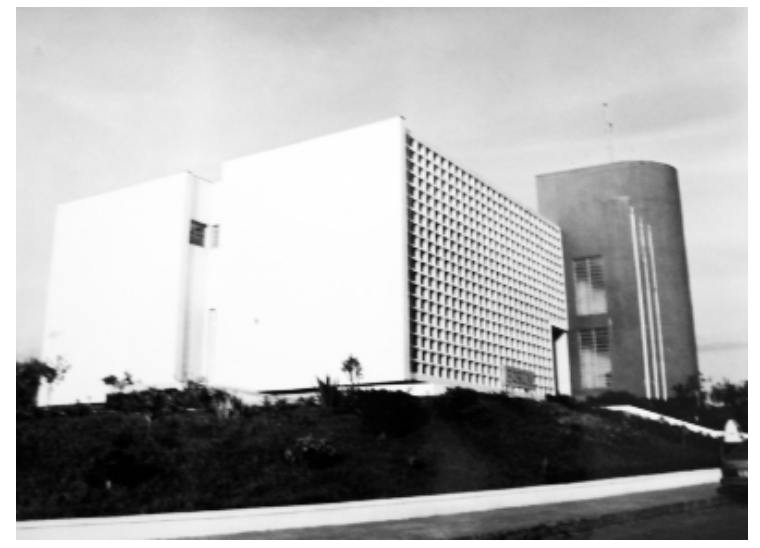

IMAGEM 40. Fórum Padrão F de Jaboticabal, Fonte: Tese de Doutorado, Maria Tereza Regina Leme de Barros Cordido, USP São Carlos, 2012. 
É importante ressaltar aqui, que somente os projetos eram padronizados, como escreveu Maria Tereza Cordido em sua teste de doutorado:

»As obras eram feitas em alvenaria tradicional por empreiteiros locais [...] que não seguiram qualquer normatização de execução de obra que não fosse semelhante a que realizavam para outros edificios quaisquer $[\ldots] . «^{13}$

Nesse sentido percebeu-se um desequilíbrio entre o planejamento de projeto, com suas especificações e precisões estabelecidas na etapa do projeto executivo; e as condições, as realidades do canteiro de obra. Podemos concluir que as construtoras e a indústria de construção não foram necessariamente interessados em uma normatização da obra e seus componentes. arquiteto Geraldo Vespaziano Puntoni explica a relação entre o DOP e as construtoras:

13 CORDIDO, Maria Tereza Regina Leme de Barros, Arquitetura Moderna: A Rede de Fóruns Modulares do Estado de São Paulo (1969-1975), Tese de Doutorado, p. 111. USP São Carlos, 2012
"[...] O DOP sempre criou uma arquitetura comprometida com as construtoras. Bastante mão de obra, quanto mais mão de obras, mais dinheiro ganhava. O DOP nunca resolveu dispersar com a indústria. Tem duas coisas díspares, a indústria da construção e a indústria do material de construção. $\ll^{14}$

Geraldo Vespaziano Puntoni não considerava a indústria da construção como indústria, pois ela se encontrava ainda em uma fase pré-industrial. Segundo o arquiteto, foi denominada indústria apenas por consideração, para que não deixa-se de acompanhar a carruagem do século. Já a indústria do material de construção se apoiou na publicidade seus produtos para manter o seu consumo. Ambos, indústria da construção e indústria do material de construção, nesse sentido, estavam em descompassadas, no entanto os materiais e componentes com os quais os edifícios foram construídos levaram para as obras sua obsolescência programada. É claro,

14 Entrevista, Geraldo Vespaziano Puntoni, 19.03.2014 
que as edificações, no que diz respeito aos seus equipamentos e acabamentos, refletiram essa situação e passaram a se desgastar com mais rapidez. Segundo o arquiteto Geraldo Vespaziano Puntoni, essa contradição só seria superada, quando a ideia de manutenção permanente dos edifícios fosse adotada, estabelecendo a normatização e padronização dos componentes e materiais de construção, construindo de forma modular as edificações. Além disso, o arquiteto identificou a contratação pública dessa época como consequência de deficiência nos projetos públicos. Geraldo Vespaziano Puntoni enfatizou a falha do dispositivo legal, que permitia que se aceitasse apenas o projeto básico para definir os projetos das contratações.

Mesmo assim o Departamento de Obras Públicas do Estado de São Paulo chegou a deter grande parte do conhecimento sobre obras, o que lhe permitiu a elaboração de um caderno de encargos e serviços, que foi considerado por muito tempo um modelo exemplar. Nele era possível encontrar diretrizes que serviram para orientar a elaboração de projetos e execução de todos os tipos de obras, definindo serviços, especificações, custos e normas para fiscalizações, medições e recebimentos.

»Essas miudezas que surgiram, como o Manual Técnico - Caderno de Encargos de Edificações, aquelas coisas todas, surgiram lá dentro (DOP). $O$ próprio departamento elaborava projetos, muitos projetos. Os primeiros modelos foram feitos lá, os de escolas, de fóruns, de cadeias. [...]."

Podemos identificar claramente uma busca pela eficiência do desempenho no DOP durante o período posterior ao PAGE, no entanto a préfrabricação não era uma prioridade. $\bigcirc$ arquiteto Geraldo Vespaziano Puntoni deixou claro que o DOP nunca teve interesse nesse sentido.

Comparando os dois momentos, a produção do PAGE, e por segundo durante a produção posterior: Os edifícios elaborados durante o PAGE propuseram espaços generosos que conseguiram quebrar as hierarquias antigas impostas pe- 


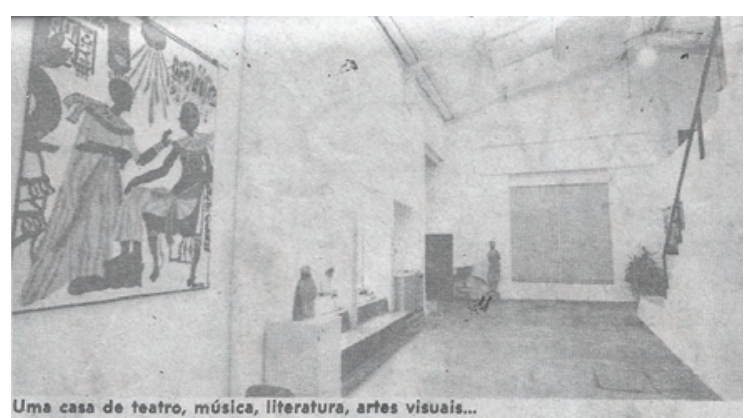

IMAGEM 41. Casa Cultural Mazzaropi, Inauguração 1982, Projetado pelo arquiteto Geraldo Vespaziano Puntoni. Fonte: Jornal da Tarde, 05.05.1982 62 los edifícios públicos, os espaços abertos articularam novas relações com seu entorno e com o espaço urbano. Nos edifícios padronizados depois do PAGE podemos identificar elementos modernos que aparecem de forma monótona, sem constituir propostas inovadoras. Os projetos parecem ter absorvido as questões modernas introduzidas pelo PAGE, mas não conseguiram se desdobrar dentro da normatização dos projetos padrões.

\section{A DIRETORIA DE OBRAS ESPECIAIS}

das Secretarias. Uma das primeiras obras especiais, elaborado por Geraldo Vespaziano Puntoni foi o Centro Cultural Mazzaropi (1982), localizado na rua Visconte de Parnaíba, no bairro da Mooca. Tratava-se de um antigo galpão que era ocupado antigamente por uma pequena indústria; acabou sendo transformado em uma casa de cultura com mais de $2000 \mathrm{~m}^{2}$. O projeto se apropriou do espaço existente sem modificar a sua estrutura. Foram utilizadas poltronas que pertenciam antigamente ao »Cine Brigadeiro» para ocupar os 325 lugares disponíveis. Além disso, a casa de cultura contava com uma galeria de arte, sala para as sedes da Orquestra Sinfônica Juvenil do Estado, sala para a seção de livros, lanchonete e dois jardins internos. Segundo Vespaziano Puntoni, toda reforma foi feita com o mínimo de gastos possível, cerca de 15 milhões de cruzeiros (1,2 milhões de reais).

DOP em 1981. De 1981 a 1988 ele trabalhou na Diretoria de Obras Especiais, cuja diretora era Thereza Katinszky (1927-2015). Essa Diretoria era encarregada das obras especiais do DOP, como por exemplo creches, centros culturais ou reformas e ampliações nos edifícios existentes
Além do Centro Cultural Mazzaropi, Geraldo Vespaziano Puntoni foi encarregado de elaborar um Centro de Convivência Infantil para a Secretaria de Estado dos Negócios dos Transportes, 
na Avenida do Estado. O projeto fez parte de uma iniciativa da administração pública Franco Montoro (1982 a 1987), com o objetivo de oferecer educação infantil para os funcionários públicos do estado.

»[...] não existia um padrão de creche. Como eu já tinha trabalhado no CECAP, quando eu projetei, eu usei as ideias do Artigas, e projetei um pátio interno."

O projeto do Centro de Convivência Infantil ficou por motivos de adaptações completamente descaraterizado, mas é utilizado ainda hoje como creche para os funcionários da Secretaria. Um espaço central une todas as funções, permitindo uma visibilidade direta. $\bigcirc$ edifício já contou com pilotis e com uma iluminação zenital de »sheds«, que foi substituída por uma nova cobertura metálica superior. Além da iluminação, a nova cobertura atrapalha a ventilação do edifício. Os antigos espaços abertos foram fechados e transformados em espaços internos. Do projeto original permaneceu apenas o pátio

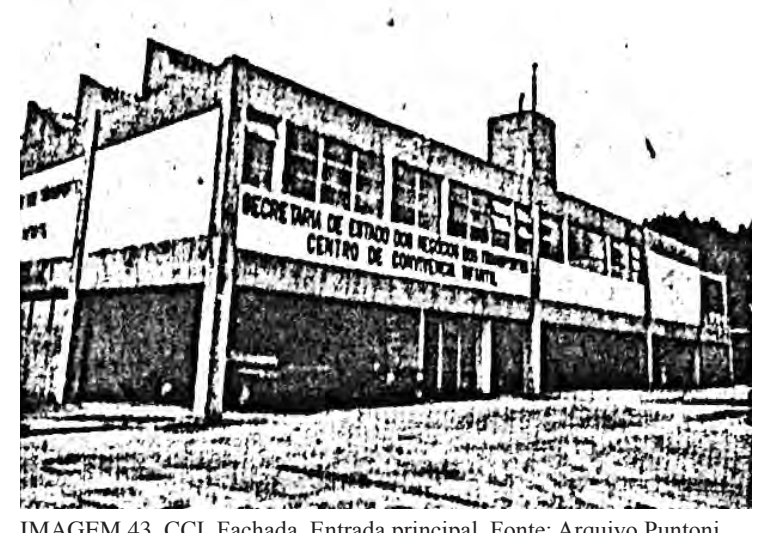

IMAGEM 43. CCI, Fachada, Entrada principal, Fonte: Arquivo Puntoni

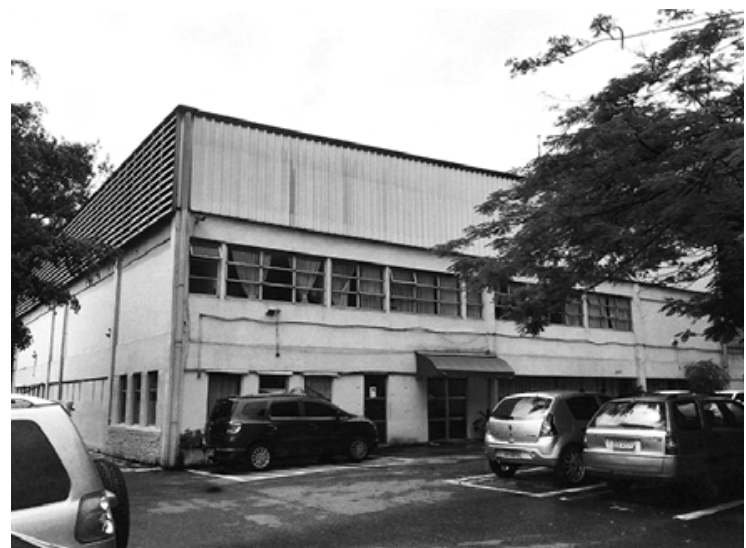

IMAGEM 44. CCI, Fachada, Entrada principal, Fonte: Sebastian Beck

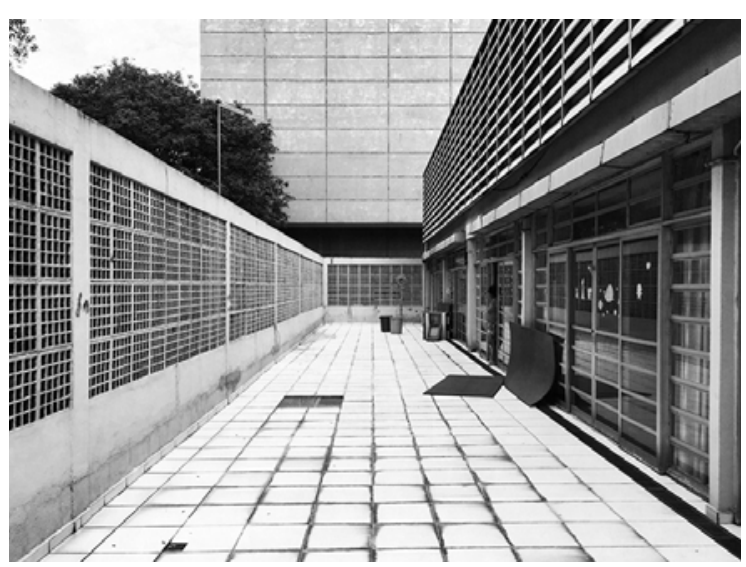

IMAGEM 42. CCI, Pátio na cobertura. Fonte: Sebastian Beck

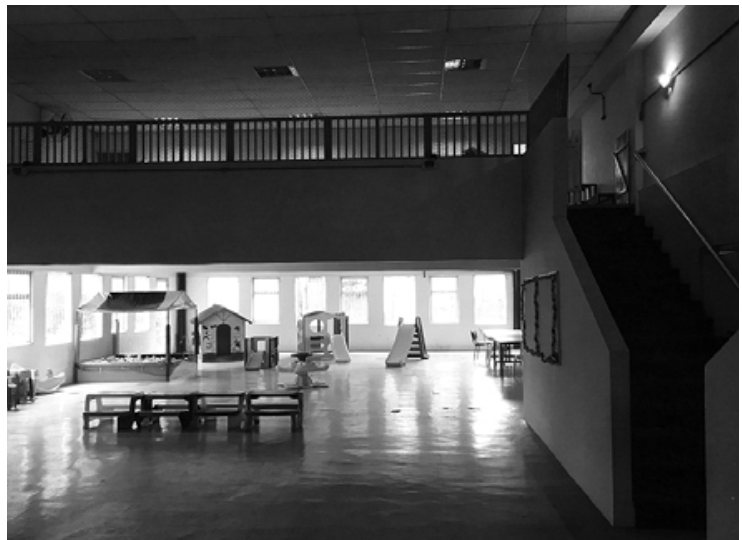

IMAGEM 45. CCI, Espaço Central, Mezanino, Fonte: Sebastian Beck 


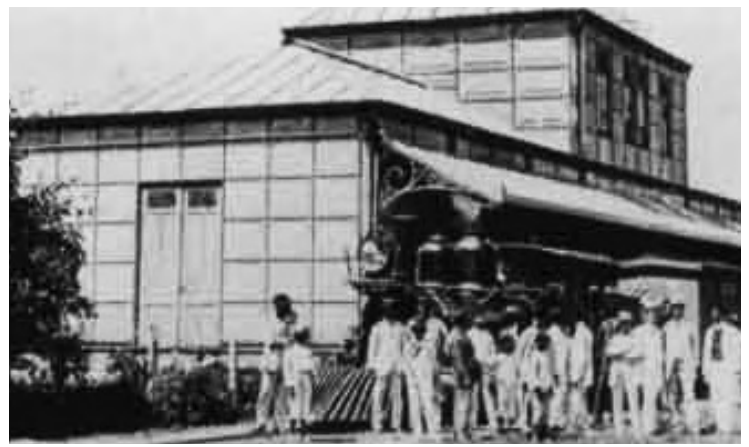

IMAGEM 47. Estação Ferroviária Bananal, 2014, Foto: www.cultura sp.gov.br/portal/site/SEC

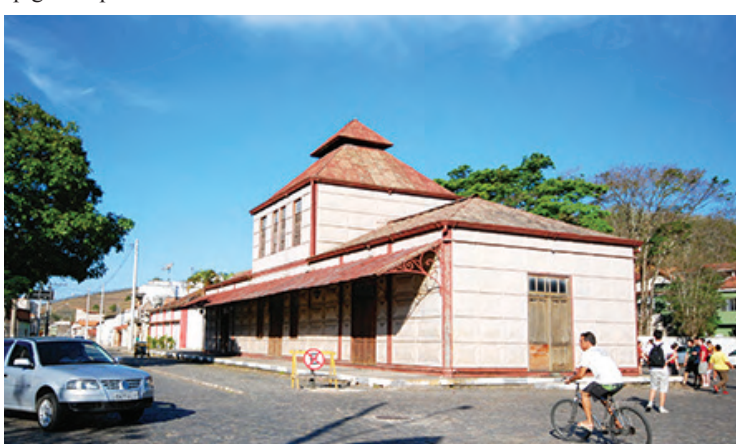

IMAGEM 48. Estação Ferroviária Bananal, 2014, Foto: Sebastian Beck

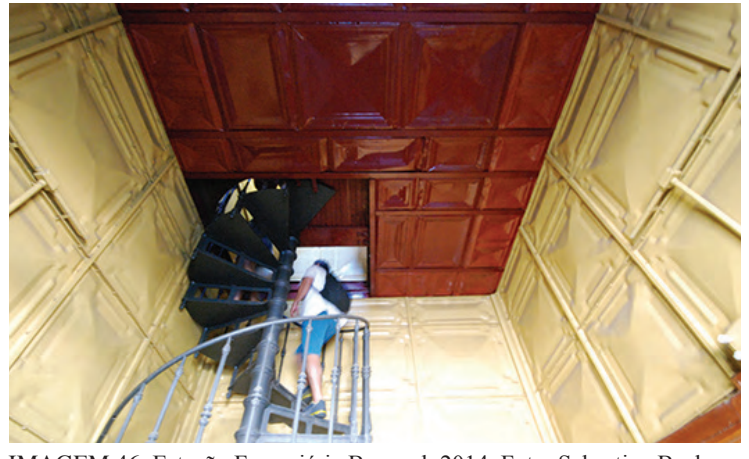

IMAGEM 46. Estação Ferroviária Bananal, 2014, Foto: Sebastian Beck

64 no terraço que se estende ao longo da fachada. Hoje frequentam ainda mais de 60 crianças entre 6 meses e 6 anos a creche.

Em 1987, o arquiteto Geraldo Vespaziano Puntoni se dedicou através da Diretoria de Obras Especiais ao trabalho da preservação do patrimônio, onde foi encarregado de avaliar os bens culturais do estado, em parceria com o Condephaat (Conselho de defesa do Patrimônio Histórico, Artístico e Paisagístico do Estado de São Paulo). Nessa atuação se destacam principalmente dois projetos, hoje preservados e restaurados. $O$ primeiro é a Estação Ferroviária de Bananal, pré-fabricada e importada da Bélgica em 1888. A estação estava com graves problemas relativos a preservação, devido a oxidação das chapas de aço provocada pela deterioração da pintura.

»A Thereza gostava de dizer: O nosso projeto aqui é fazer restauro, ou seja, constrói quatro colunas, cobre (o edifício tombado), e deixa a obra aí« ${ }^{15}$

15 Entrevista, Geraldo Vespaziano Puntoni, 26.05.2014
Thereza Katinszki pode ter sido sarcástica, mas do ponto de vista da preservação de um bem cultural, as »quatro colunas« protegeram as obras com uma importância significativa para a memória do país. Como o processos de reconhecer um bem cultural costuma ser lento, as iniciativas da Diretoria das Obras Especiais provavelmente salvaram diversas obras da decadência.

O segundo projeto, o Sobrado Valim, também em Bananal, foi analisado e estudado pelo arquiteto Geraldo Vespaziano Puntoni. A carta de Paulo de Mello Bastos (Presidente do Condephaat) para Pedro Lombardi (Superintendente do DOP) comprovou os estudos do arquiteto referentes ao restauro do sobrado. Paulo de Mello Bastos sugeriu, devido às limitações relativas a verba, a execução de diversos serviços, como reforços estruturais, restauro da estrutura de madeira e da cobertura e o tratamento das peças de madeira com cupinicidas. Os serviços solicitados se basearam no levantamento feito pela Secretaria de Cultura junto de Vespaziano Puntoni, então 
representante da Diretoria de Obras Especiais.

A preocupação com o patrimônio histórico tem suas origens no movimento moderno e está vinculada a nomes consagrados como Mario de Andrade e Lúcio Costa. A possibilidade de pesquisa e levantamento do acervo de bens culturais dispersos e em estado de decadência, só é de fato possível se aliada ao aparelho de Estado, o que constitui uma política de patrimônio.

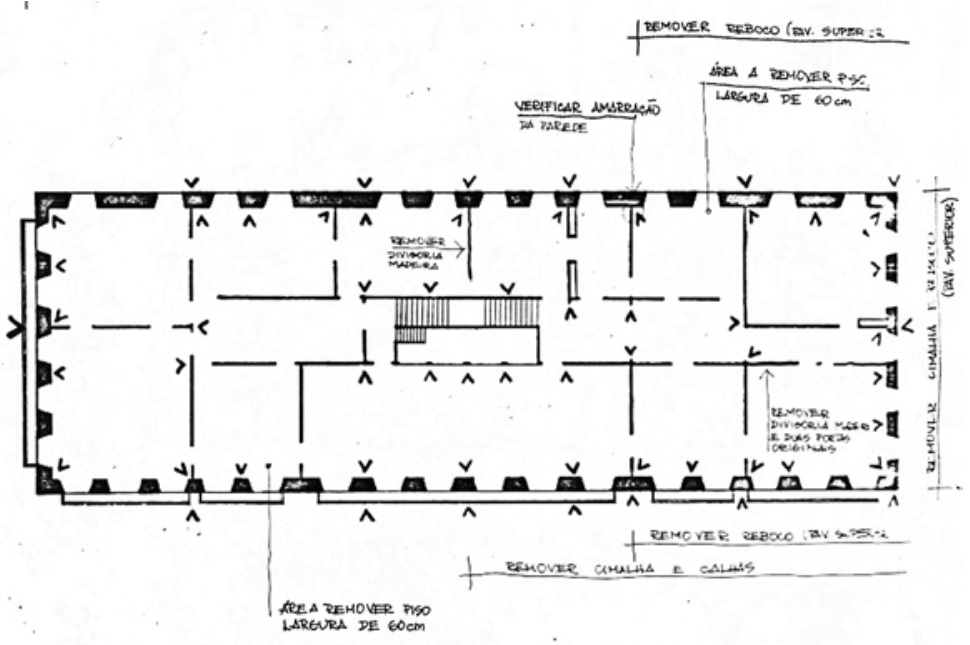

PAVIMENTO SUPERIOR

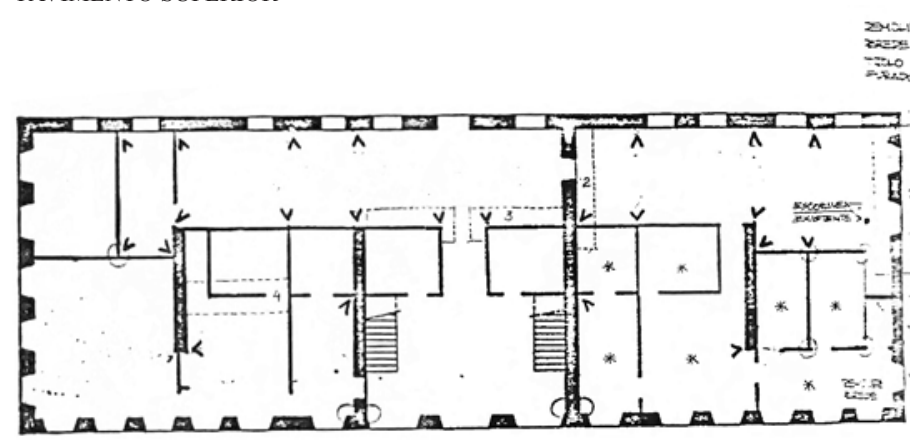

PAVIMENTO TÉRREO

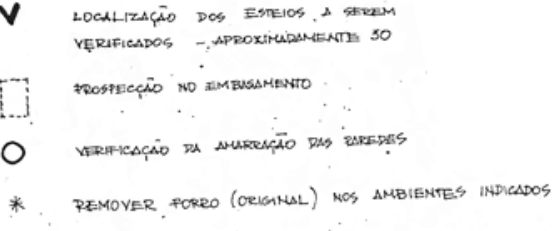

IMAGEM 49. Sobrado Valim, Bananal, Pavimento Superior, Planta de levantamento, Prospecções, Demolições, Retiradas, 1987, Fonte: Arquivo Condephaat

IMAGEM 50. Sobrado Valim, Bananal, Pavimento Térreo, Planta de levantamento, Prospecções, Demolições, Retiradas, 1987, Fonte: Arquivo Condephaat 


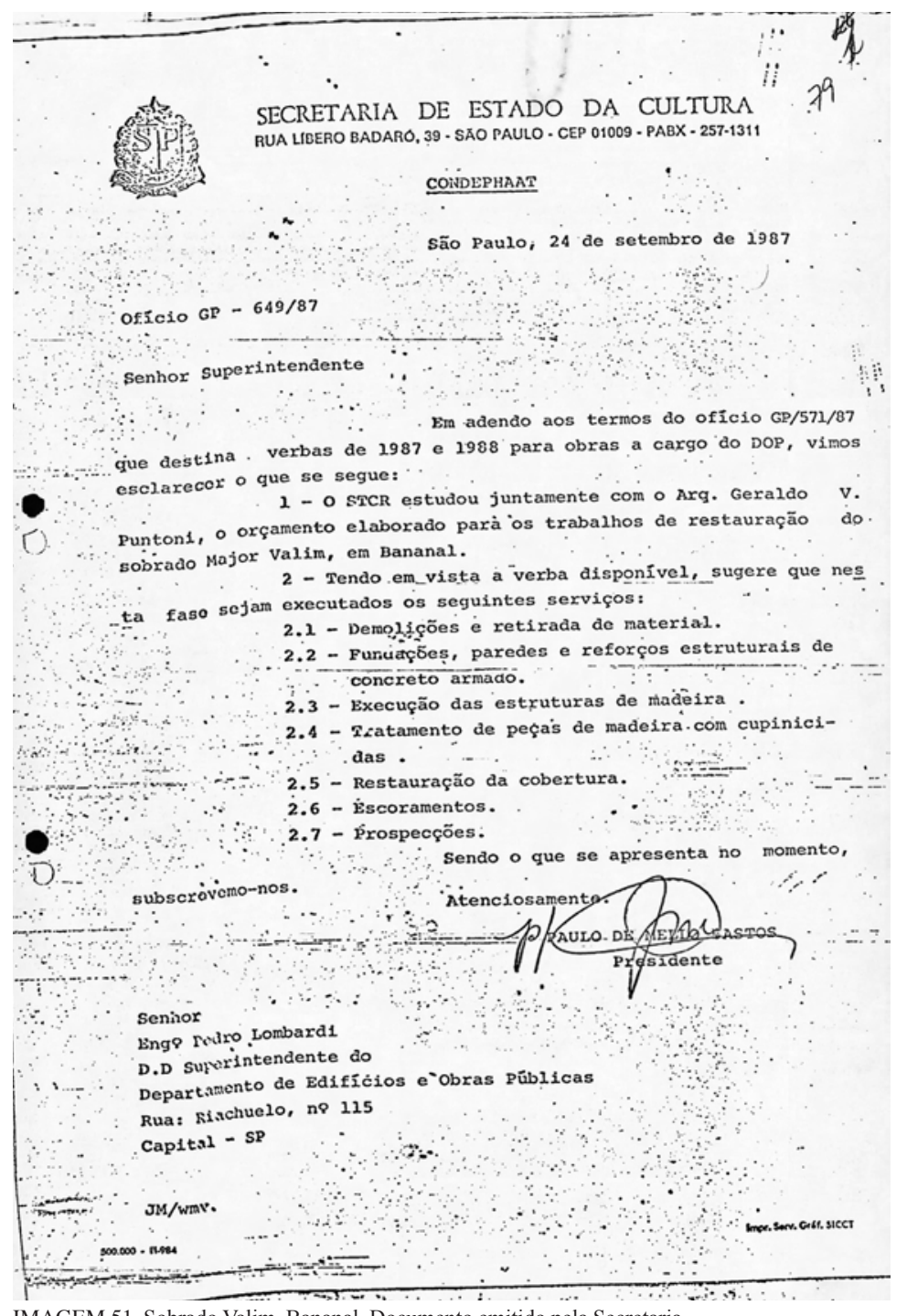

IMAGEM 51. Sobrado Valim, Bananal, Documento emitido pela Secretaria

de Estado da Cultura, Condephaat, 1987, Fonte: Acervo Condephaat

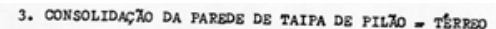

3.1. Taipa substituida por ti jolo ou rado Recospor trecho da parede conforme indicado na ples esquenática en alvenária de tij jolo comun conforme es
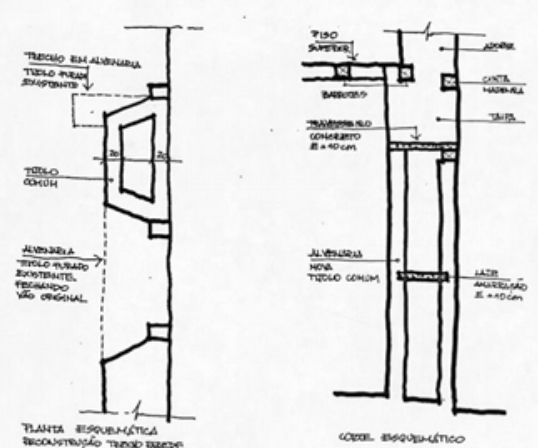

Para efeito de orçanento considerar alternativa par esse servico un solo cimento em toda espessura oris

IMAGEM 52. Sobrado Valim, Bananal, Detalhe de levantamento, Consolidação da parede de taipa de pilão, 1987, Fonte: Arquivo Condephaat

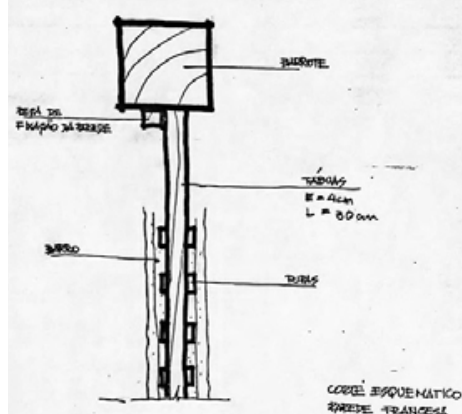

\section{BARROTES DO PISO}

substituir pecas comprometidas por outra nas mesmas dimensöes ou trechos deteriorados conforme detalhe. para efeito de orçamento prever substituiçãa inte gral de barrotes ( 5 peças de $\tilde{z} 20 \times 20 \times 600$ ) substituição de $1 \mathrm{~m}$, conforme detalhe, em 30 pecas. 15 con Paleaso / is an besinis

IMAGEM 53. Sobrado Valim, Bananal, Detalhe de levantamento, Barrotes do Piso, 1987, Fonte: Arquivo Condephaat 

Inlin:

[Recorte 1973 - 1979]
EMURB - Empresa Municipal de Urbanização

[Recorte 1970 - 1973]

MINAH

[Recorte 1967-1970]

CECAP - Caixa Estadual de Casas para o Povo

[Recorte 1963 - 1967]

FECE - Fundo Estadual de Construções Escolares

[Recorte 1961 - 1990]

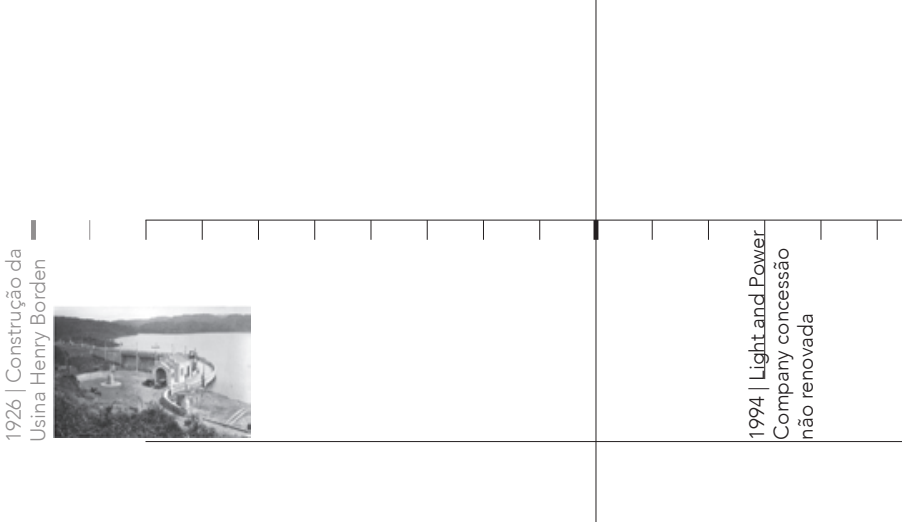

Wn औ औ

ars de Öbras públicas
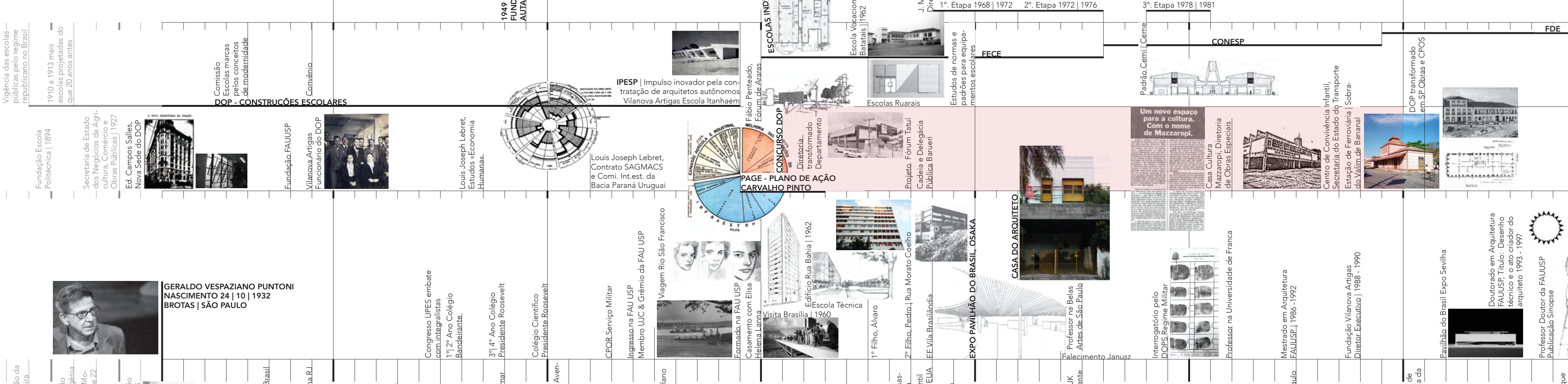



\section{CAPÍTULO 01 - DEPARTAMENTO DE OBRAS PÚBLICAS DO ESTADO}

\section{LISTA DE PROJETOS}

Grupo construído pelo Governo do Estado

Penitenciária Feminina da Secretaria da Justiça

do Estado de São Paulo

Secretaria de Cultura do Estado de São Paulo

Edifício do Tribunal da Justiça Militar

Secretaria de Transporte do Estado

Secretaria da Cultura do Estado de São Paulo
Levantamento da situação física dos prédios es-

colares estaduais da região metropolitana

Reforma e ampliação dos Edifícios da Penitenciária Feminina, Carandirú, São Paulo

Sobrado Vallim, Bananal, SP

Obras de preservação e restauro parcial

Estação Ferroviária, Bananal, SP

Obra de preservação e restauro da estação

Obras de reforma da cobertura e do subsolo,

Rua Vilanova N²68, Vila Buarque, São Paulo

Edifício do Centro de Convivência Infantil,

Ponte Pequena, São Paulo

Sobrado Major Novaes,

1987

1988

$1987-1988$

$1987-1988$

1988

1988

obras de preservação e restauro 
Edifício da Seção de Transporte do DOP

Secretaria de Educação do Estado de São Paulo

Secretaria de Transporte do Estado de São Paulo

Secretaria de Cultura do Estado de São Paulo

Secretaria de Segurança do Estado de São Paulo

Secretaria da Justiça do Estado de São Paulo
Consolação, São Paulo,

1986

obras de reforma e adaptação

Edifício da Coordenadoria de Ensino e Normas

$1981-1982$

Pedagógicas, reforma e instalação do Centro

de Convivência Infantil, Perdizes, São Paulo

Edifício do Centro de Convivência Infantil,

$1981-1982$

Av. do Estado, Brás, São Paulo

Centro Cultural Amásio Mazzaropi, reforma e adaptação de três edifícios para a instalação do

Centro Cultural. Bresser, São Paulo

Edifício da Cadeia e Delegacia Pública, Barueri

São Paulo

Edifício do Fórum, Tatuí, São Paulo 


\section{BIBLIOGRAFIA}

Obras de referência do arquiteto Geraldo Vespaziano Puntoni: Acervo particular do arquiteto

ANDRADE, Antonio Luiz Dias de. Um Estado Completo que Pode Jamais ter Existido. São Paulo, Faculdade de Arquitetura e Urbanismo da Universidade de São Paulo, Tese de Doutoramento, 1993.

ARGAN, Giulio Carlo. História da Arte como história da cidade. São Paulo, Martins Fontes, 1992.

BARROS CORDIDO, Maria Tereza de. Arquitetura Moderna: A Rede de Fóruns Modulares do Estado de São Paulo (1969-1975). São Carlos, Faculdade de Arquitetura e Urbanismo da Universidade de São Paulo, Tese de Doutoramento, 2012.
BENÉVOLO, Leonardo. História da Arquitetura Moderna. São Paulo, Perspectiva, 1976.

BUZZAR, Miguel Antonio. João Batista Vilanova Artigas, Elementos para uma Compreensão de um Caminho da Arquitetura Brasileira, 19381967. São Paulo: FAU USP, 1996, (dissertação de mestrado).

DOP, Departamento de Edifícios e Obras Públicas, Relatório 1970, Governo do Estado de São Paulo, Secretária dos Serviços e Obras Públicas

DOP, Secretaria dos Serviços e Obras Públicas. Departamento de Edifícios e Obras Públicas. Manual Técnico do DOP São Paulo, 1971

PAGE- Relatórios do Plano de Ação; PINTO, Carvalho, Plano de Ação do Governo, São Paulo: Imprensa Oficial, 1959.
SÃO PAULO (ESTADO). Secretaria dos Serviços e Obras Públicas. O DOP e a Padronização de Projetos para Obras Públicas - Palestra do Eng. Aurélio Araújo, São Paulo, 1974.

SEGAWA, Hugo. Arquiteturas no Brasil, 19001990. São Paulo: EDUSP, 2002.

SIMÕES JÚNIOR, José Geraldo, O setor de obras públicas e as origens do urbanismo na cidade de São Paulo. Dissertação (Mestrado em Administração), Escola de Administração de Empresas. Fundação Getúlio Vargas, São Paulo, 1990.

REIS FILHO, Nestor Goulart. São Paulo: Vila Cidade Metrópole. Prefeitura de São Paulo, 2004.

TOLEDO, Benedito Lima de. São Paulo: Três Cidadesemum Século.SãoPaulo, DuasCidades, 1983. 


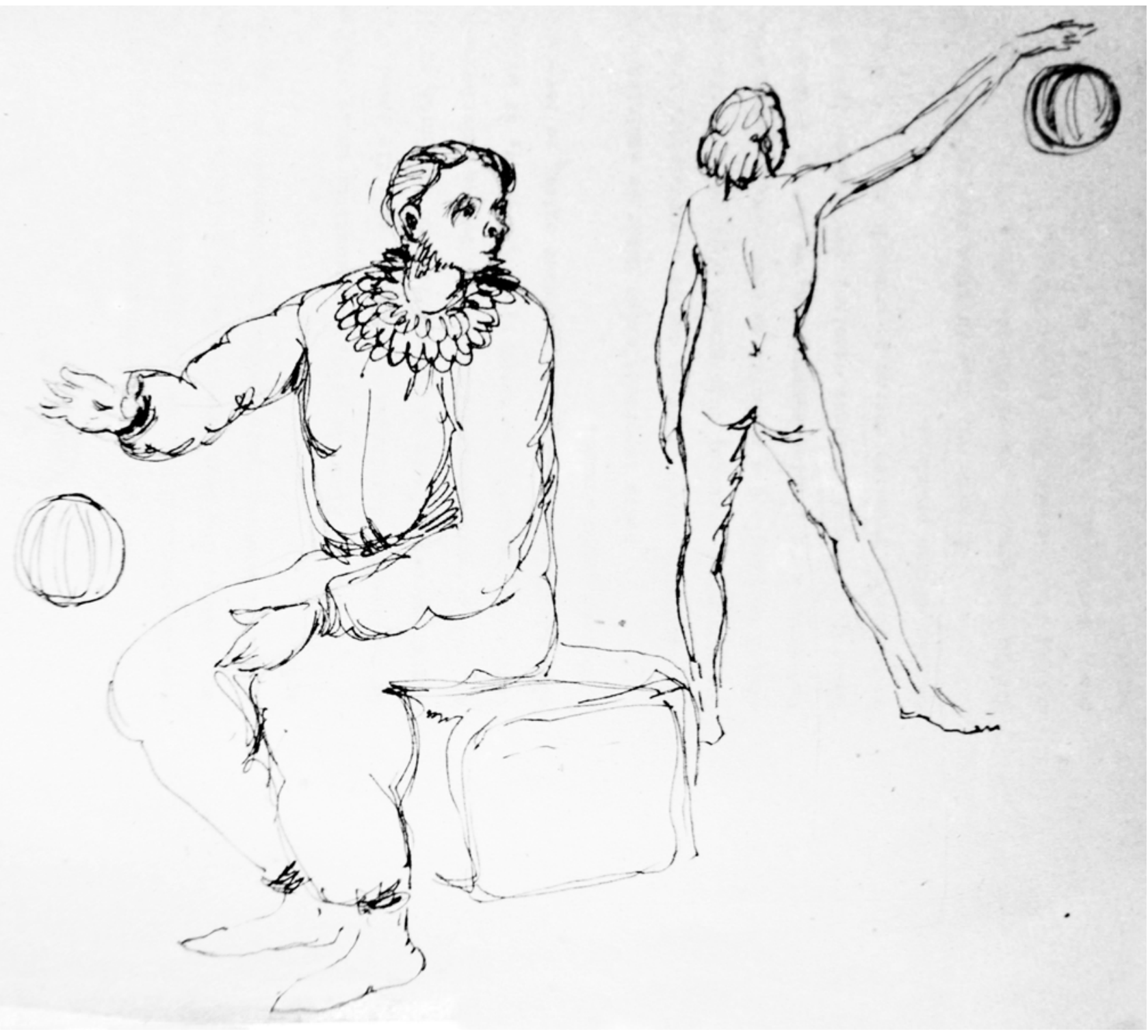


Este capítulo pretende fazer considerações sobre o primeiro órgão do governo do Estado de São Paulo a ter como única atribuição: Planejar, construir, ampliar e manter a rede pública estadual de ensino. Importante no contexto da história do FECE (Fundo Estadual de Construções Escolares) foi o Governo Carvalho Pinto e seu Plano de Ação para a gestão de 1959 a 1963. Ele estabeleceu metas, prioridades e prazos a serem cumpridos e conseguiu impor reformulações administrativas. Um resultado dessa mudança política foi o FECE, criado para cuidar de todo planejamento da área de educação do Estado de São Paulo. Objetivo desse capítulo é esclarecer a relação política entre os órgãos DOP, IPESP e FECE, que permitiu a atuação do arquiteto Geraldo Vespaziano Puntoni nos anos 1961 a 1968, nesse órgão significativo para a construção de edifícios escolares no Estado de São Paulo. Outra intenção desta abordagem é investigar o que foi produzido nesse período da história do FECE, e o quanto estas ambições influenciaram e foram influenciadas pelo arquiteto Geraldo Vespaziano Puntoni.

\section{A HISTÓRIA DA CONSTRUÇÃO ESCOLAR PAULISTA}

A história das escolas públicas do Estado de São Paulo data de 1890, com a vigência do regime republicano no Brasil. Até o fim da primeira década do século XX, grande parte dos grupos escolares eram em prédios adaptados. Mas entre 1910 e 1913 projetam-se mais escolas que nos vinte anos anteriores. As escolas dos anos 30 são marcadas pela adoção de conceitos de modernidade. Já os anos 50 são conhecidos pela disseminação da arquitetura moderna nos prédios escolares paulistas. No início da década de 60, através do Governo Carvalho Pinto, há um impulso renovador das escolas com o Instituto de Previdência do Estado de São Paulo
IMAGEM 54. Desenho Geraldo Vespaziano Puntoni, 1962, Fonte: Arquivo do Sílvio Breno de Souza Santos. 
- IPESP. Durante a gestão de Carvalho Pinto, foi selado um acordo entre o governo e o IAB para que os prédios executados durante a gestão fossem feitos com projetos elaborados pelos escritórios paulistas de arquitetura.

»A contribuição dada pelos arquitetos à obra pública à partir desse momento é relevante na medida em que amplia o número de pessoas participando dessa produção cultural, enriquecendo o processo. [...] Assim, nesse momento, introduz-se uma forma inédita de elaborar os projetos dos edifícios escolares públicos, quando a produção é terceirizada a profissionais liberais, que trazem uma contri-

Cronologia das Construção Escolar Paulista

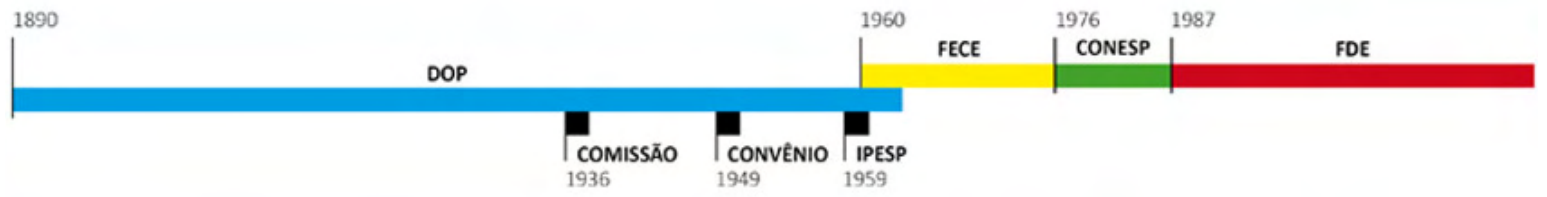

DOP: Departamento de Obras Públicas PESP: Instituto de Previdéncia do Estado de Săo Paulo FDE: Fundaşăo para o Desenvolvimento da Educą̧̧ă

de Construşōes Escolares

CONESP: Companhia de Construç̧̄es Escolares do Estado de Säo Paulo

IMAGEM 55. Cronologia da Construção Escolar Paulista. Fonte: http://www.fde.sp.gov.br/PagePublic/Interna

76 buição significativa à arquitetura produzida. Mas, sobretudo, o mérito da medida está na valorização do projeto especifico para cada obra que, sem dúvida, resulta numa arquitetura de melhor qualidade ${ }^{1}$

A Diretoria de Obras Públicas (DOP) foi o órgão responsável pelas escolas estaduais até 1960. A partir daí, a atribuição de construir e manter escolas públicas passa a ser do Fundo Estadual de Construções Escolares (FECE). O novo Fundo foi localizado no Largo do Arouche 302, no $13^{\circ}$ andar, junto com a Secretaria de Educação. Criado através do Plano de Ação Carvalho Pinto, Artigo $3^{\circ}$, citado no capitulo anterior. ${ }^{2} \mathrm{O}$ primeiro Diretor do FECE foi Carlos Pasquale de 1960 a 1961, durante o governo Carvalho Pinto. Depois de um ano como Diretor, ele foi convidado para ser o novo Secretário da Educação. Carlos Pasquale chamou Sílvio Breno de Souza

FDE, Arquitetura Escolar Paulista, anos 1950 e 1960. São Paulo: Imprensaoficial, 2006. p.18.

2 Idem. p.52 
Santos ${ }^{3}$, uma das testemunhas entrevistadas para esbouçar a história do FECE. Depois da curta direção do Carlos Pasquale, entrou Flavio Villaça ${ }^{4}(1961$ - 1962) como novo Diretor do Fundo.

Em 1961 entrou o arquiteto Geraldo Vespaziano Puntoni no FECE, e fez parte da equipe de planejamento. Encarregado para desenvolver as novas Escolas Industriais, analisadas em seguida nesse capítulo. Em 1962 terminou o governo Carvalho Pinto e Adhemar de Barros (1962 - 1965) entrou como novo Governador do Estado de São Paulo. O FECE começava a discutir

3 Sílvio Breno de Souza Santos nasceu em setembro de 1933. Formado na Faculdade de Arquitetura e Urbanismo da Universidade de São Paulo em 1958. Ainda como semi - profissional, Sílvio Breno começava sua carreir como arquiteto no DOP - Departamentos de Obras Públicas. Depois ele trabalhou 39 anos no FECE - Fundo Estadual de Construções Escolares, CONESP - Companhia de Construções Escolares do Estado de São Paulo e FDE - Fundação para o Desenvolvimento da Educação, vivendo todas as mudanças políticas no órgão. O Arquiteto entrou em janeiro de 1960 no FECE, junto com os arquitetos Marlene Picarelli e o Arnaldo Tonissi.

4 Flávio Villaça, planejador urbano, atuante na vida acadêmica e pesquisador. Suas diversa publicações são contribuições essenciais para o planejamento urbano no Brasil, consequiência de um profissional não só acadêmico como também prático, pois foi consultor de diversos órgãos de planejamento urbano do Governo do Estado e da Prefeitura Municipal de São Paulo como também participou da elaboração de vários planos diretores. Fonte: http://www.vitruvius.com.br/revistas/read/entrevista/06.024/3309 as questões da programação da escola. Escolas exemplares foram estudadas, tudo em busca de uma programação pedagógica e programação arquitetônica espacial. Além disso surgiram novos temas como a pré-fabricação, mobiliários urbanos e a padronização das escolas. Ainda durante o Governo Adhemar de Barros o FECE começou a construir escolas. De 1967 a 1968, Geraldo Vespaziano Puntoni foi Diretor Técnico do FECE. Em 1968 ele pediu a demissão e voltou para o DOP. O final dos anos 60 foi marcado pela reestruturação do FECE. Através de uma grande demanda de novos fiscais, Silvio Bre-
IMAGEM 56. Gráfico, Edifícios escolares públicos construídos no Estado S São Paulo. FDE, Arquitetura Escolr Paulista, anos 1950 e 1960. S Paulo: imprensaoficial 2006. p.16. A produção quantitativa das escolas passa a expressar números significativos justamente em meados do século 20, chegando a seu ápice em meados da década de 1970. Tais indicadores são reflexos do crescimento do país, em particular do Estado de São Paulo.

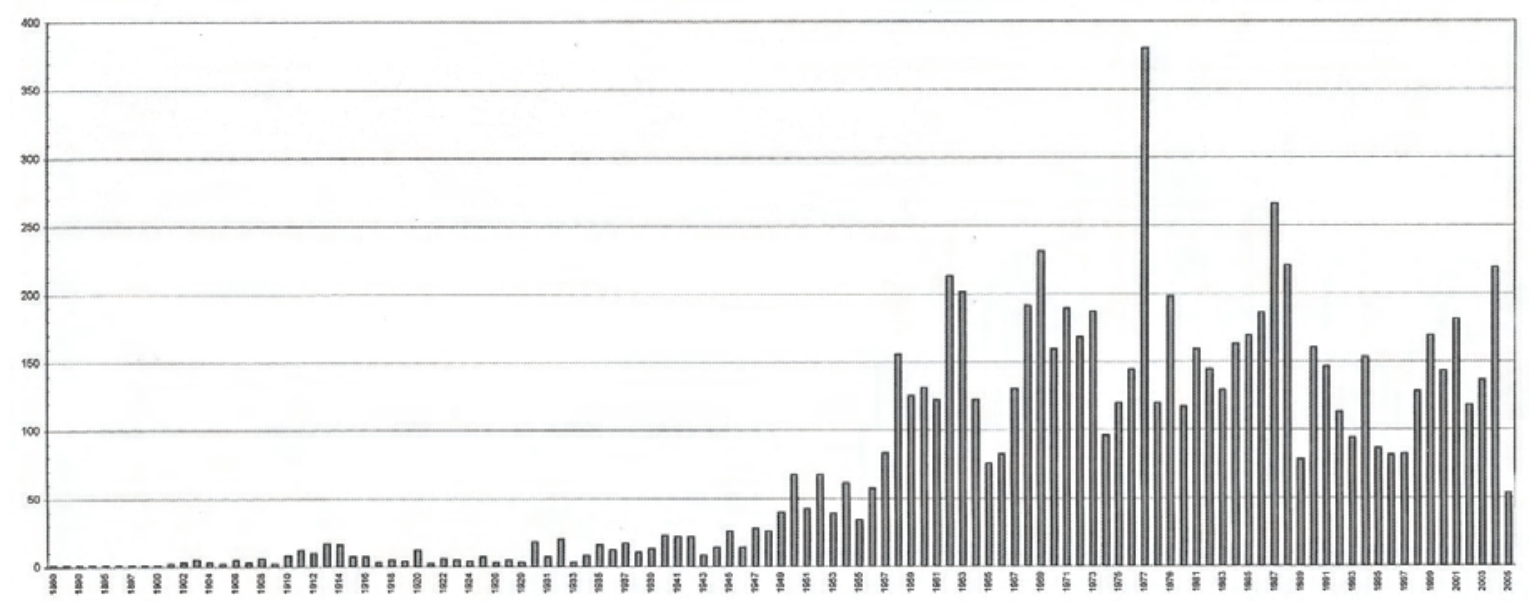


CRONOGRAMA PRESIDENCIAL | GOVERNAMENTAL - FECE | CONESP | FDE

\begin{tabular}{|c|c|c|c|c|c|}
\hline Órgão & Local & & Diretor & Ano & Governo \\
\hline \multirow{13}{*}{ 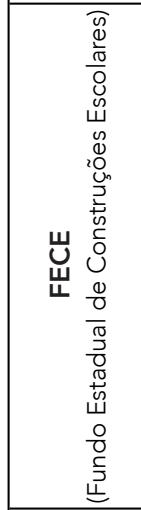 } & \multirow{5}{*}{ 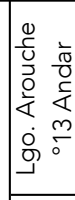 } & 1. & Carlos Pasquale & $1960-1961$ & \multirow[b]{2}{*}{ Carvalho Pinto } \\
\hline & & t. 2. & Flavio Villaça & $1961-1962$ & \\
\hline & & 3. & Manoel Rodrigues Ferreira* & 1962 & \multirow[b]{4}{*}{ Adhemar de Barros } \\
\hline & & 4. & Olavo Freitas Carvalho & 1963 & \\
\hline & & 5. & Domingos Facchini & $1964-1965$ & \\
\hline & \multirow{6}{*}{ 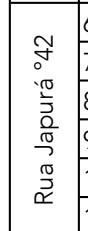 } & 6. & Arnaud Verniot & 1965 & \\
\hline & & 7. & José Mendonça Florim & $1965-1966$ & Laudo Natel \\
\hline & & 8. & José Washington Boarim & $1966-1968$ & \multirow[b]{3}{*}{ Abreu Sodré } \\
\hline & & 9. & Antonio Etzel Neto & 1968 & \\
\hline & & \multirow{2}{*}{$\frac{10}{11}$} & Antonio Carlos Abreu Sodré & $1968-1970$ & \\
\hline & & & Jõao Pedero de Carvalho Neto & $1970-1973$ & \multirow[b]{2}{*}{ Laudo Natel } \\
\hline & \multirow{10}{*}{ 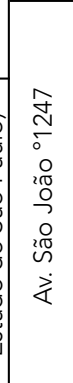 } & 12. & Ruy de Aquino & $1973-1974$ & \\
\hline & & 13. & Gilberto Waack Bueno & $1974-1978$ & Paulo Egidio \\
\hline \multirow{8}{*}{ 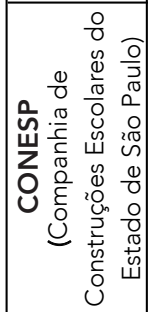 } & & 14. & Wilken Manoel Neves & 1978 & \multirow[b]{4}{*}{ Paulo Maluf } \\
\hline & & 15. & Mituo Minami & $1978-1981$ & \\
\hline & & 16. & Alécio Jaruche & $1981-1982$ & \\
\hline & & 17. & Walter Mauro & 1982 & \\
\hline & & 18. & Mario Ladeia & $1982-1983$ & \multirow[b]{3}{*}{ Franco Montoro } \\
\hline & & 19. & Ivan Correa Toldeo & $1984-1986$ & \\
\hline & & 20. & Marciano Araujo Neto & $1986-1987$ & \\
\hline & & 21. & Nelson Barbieri & $1987-1988$ & \multirow[b]{4}{*}{ Orestes Quércia } \\
\hline \multirow{9}{*}{ 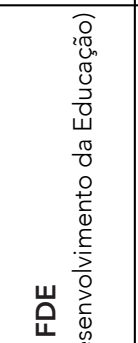 } & \multirow{9}{*}{ 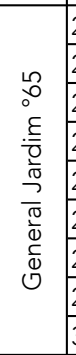 } & 22. & Décio Moreira & $1988-1989$ & \\
\hline & & 23. & Carlos Nelson Bueno & $1989-1990$ & \\
\hline & & 24. & João Alberto Viol & $1990-1991$ & \\
\hline & & 25. & César Callegari & $1991-1994$ & \multirow[b]{2}{*}{ Luiz A. Fleury Filho } \\
\hline & & 26. & Augusto Luiz Rodrigues & $1994-1995$ & \\
\hline & & 27. & Lauro Almeida Carneiro Filho & $1995-1996$ & \multirow[b]{2}{*}{ Mário Covas } \\
\hline & & 28. & Sami Bussab & $1996-2003$ & \\
\hline & & 29. & Gianpaolo Poggio Smanio & $2003-2003$ & \multirow[b]{4}{*}{ Geraldo Alckmin } \\
\hline & & 30. & Sérgio Akio Kobayashi & $2003-2003$ & \\
\hline $\begin{array}{l}0 \\
0\end{array}$ & \multirow{6}{*}{ 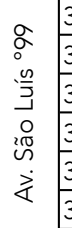 } & 31. & Tirone Francisco C. Lanix & $2003-2005$ & \\
\hline$\frac{\pi}{\frac{\pi}{\sigma}}$ & & 32. & Miguel Moubadda Haddad & $2005-2006$ & \\
\hline $\begin{array}{l}0 \\
0 \\
0\end{array}$ & & 33. & Willian Sampaio de Oliveira & $2006-2007$ & Cláudio Lembo \\
\hline 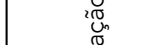 & & 34. & Fábio Bonini Simões de Lima & $2007-2011$ & José Serra \\
\hline $\begin{array}{ll}\frac{\pi}{0} \\
\stackrel{5}{=}\end{array}$ & & 35. & José Bernardo Ortiz & $2011-2012$ & Alberto Goldman \\
\hline 蛋 & & 36. & Barjas Negri & 2013 & Geraldo Alckmin \\
\hline
\end{tabular}

no foi transferido para a fiscalização de projeto (1969-1973). Segundo Sílvio Breno, os funcionários do FECE não tinham direito de ser funcionário publico, e nem direito ao INSS (Instituto Nacional do Seguro Social). ${ }^{5}$ Em 1974 - 1978 entrou Gilberto Waack Bueno como Presidente do FECE. Ele conseguiu passar o órgão para uma autarquia. O FECE, que virou a Companhia das Construções Escolares do Estado de São Paulo - CONESP, que assumiu a responsabilidade pelas escolas paulistas em 1976. Um órgão muito bem organizado, bem montado e atualizado, segundo Sílvio Breno. ${ }^{5}$ Depois de Gilberto Waack Bueno entraram oito outros diretores até a CONESP passou a ser a Fundação para o Desenvolvimento da Educação - FDE - o órgão responsável a partir de sua criação, em 1987. Em 1988 a FDE mudou-se da Av. São João ${ }^{0} 1247$ para a Rua General Jardim 65 (Hoje: Associação Escola da Cidade). A FDE continuava a funcionar praticamente como na CONESP, eles mantiveram os funcionários mas o órgão não era mais 
uma autarquia. A FDE perdeu a sua autonomia e costumava fazer convênios com a prefeitura. Hoje a FDE é localizada na Avenida São Luís, 99.

\section{AS RELAÇÕES ENTRE \\ DOP - FECE - IPESP}

»Na área de educação, Carvalho Pinto cria o FECE para atender à construção, ampliação e equipamento de prédios destinados a escolas de ensino público primário e secundário do Estado. No início contudo, esse órgão desempenha apenas a função de planejar, ficando ao IPESP a incumbência de elaborar os projetos e executar as construções escolares. ${ }^{6}$

Até o início do Governo Carvalho Pinto, a rede escolar foi elaborada e construída pelos funcionários dos órgãos públicos como o DOP. O FECE foi lançado principalmente para não ter interferência política na escolha de terrenos para as

6 FDE, Arquitetura Escolar Paulista, anos 1950 e 1960. São Paulo: imprensaoficial , 2006. p.17 novas escolas demandadas pelo Plano de Ação. O FECE fez um registro de cadastro, levando em consideração todas as plantas das cidades do interior de São Paulo. Nesse mapeamento o FECE localizava todas as escolas existentes. Além disso o levantamento analisava exatamente onde as cidades estavam crescendo.

»No Governo Carvalho Pinto o negócio se inverteu. Antes era assim: Os deputados e prefeitos vinham do interior e pediam uma escola nova e o Governo fazia, independente para o que era aquela escola. Quando começou o Governo Carvalho Pinto, isso se inverteu: A gente planejava - não adiantava o deputado pedir uma escola. Só se aquela cidade precisasse de uma escola a gente mandava construir. ${ }^{7}$

Quem coordenava todo planejamento no FECE na época, eram Clementina Delfina de Ambrosis e Sabatina Gervásio. No início do Fundo, o foco principal era o desenvolvimento do cadastro e a definição dos terrenos, para poder cons-

\footnotetext{
7 Entrevista, Marlene Picarelli, 04.07.2016
} 


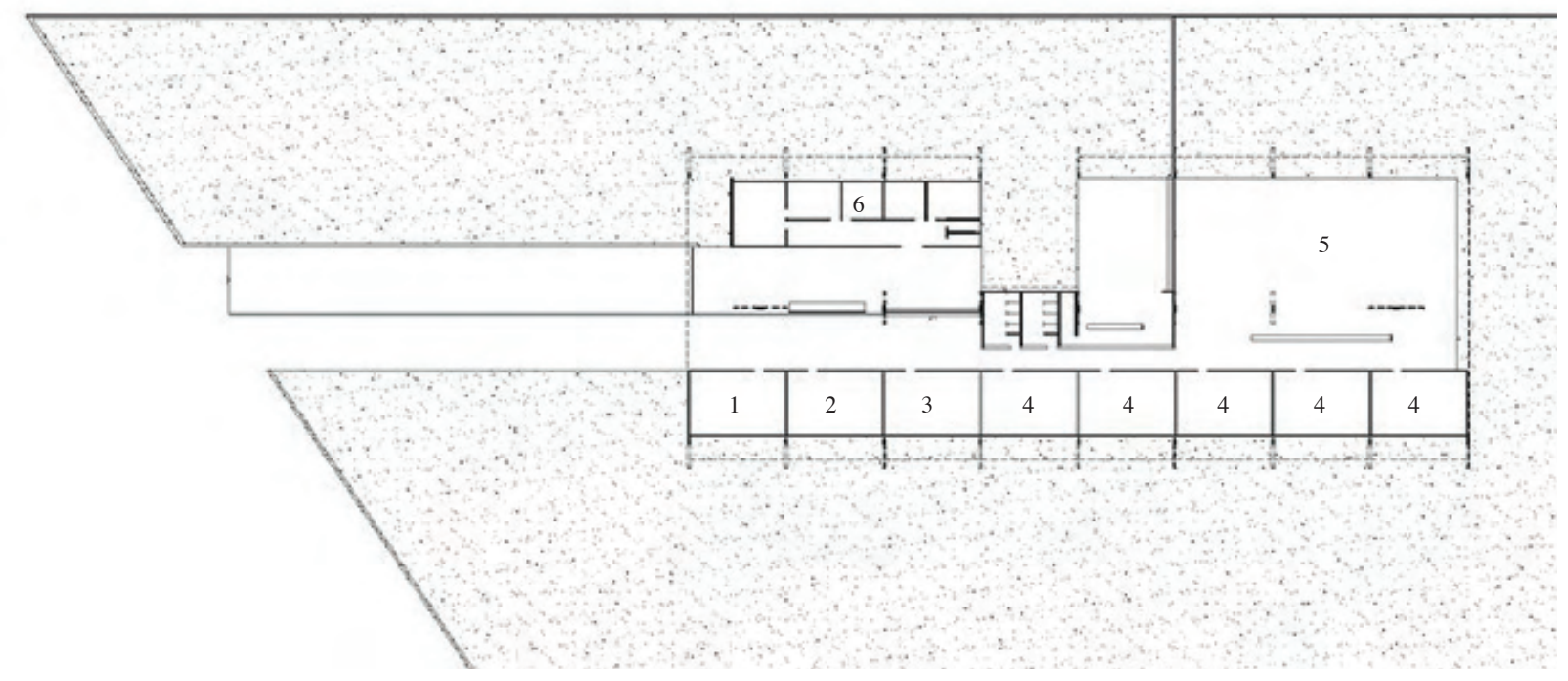

1 Pavimento Térreo

truir as novas escolas. Enquanto isso, o DOP e o IPESP continuavam construindo as escolas.

O IPESP foi criado em 1935, através da Constituição Estadual, com a finalidade inicial de amparar o serviço público e seus dependentes. Em cerca de 20 anos de existência, o compromisso com o pagamento de aposentadorias era ainda mais baixo, prevalecendo apenas as atribuições dos servidores, portanto, O IPESP possuía a partir de 1957 muita verba disponível. O IPESP era uma autarquia, que paga-
3. Trabalhos Manuais

5. Recreio Coberto va as obras das escolas a partir do Plano de Ação, e ele foi um órgão muito mais ágil do que o DOP. Para construir as escolas o DOP e o IPESP trabalharam em paralelo. Segundo as verificações da pesquisa do Flávio Handlich foram construídas pelo DOP 221 escolas e pelo IPESP 73 escolas no período de 1959 a $1962 .{ }^{8}$

Com a contratação de arquitetos autônomos através do IPESP, surgiu um novo debate sobre a arquitetura dos edifícios escolares. Principalmente a Escola Estadual de Itanhaém, construída pelos arquitetos Vilanova Artigas e Carlos Cascaldi em 1959, virou uma grande referência projetual para outros arquitetos, incluindo os arquitetos dos órgãos públicos do estado, como o arquiteto Geraldo Vespaziano Puntoni. Os arquitetos projetaram uma escola em que o ponto de encontro é o espaço mais importante na hierarquia espacial. A fluidez, os percursos infinitos, sua permeabilidade

8 Flávio Handlich, "As Escolas do IPESP: Projetos de Edifícios Escolares produzidos para o Instituto de Previdência do Estado de São Paulo de 1959 a1962". São Paulo: FAU USP, 2009 (dissertação de mestrado). p. 19.
IMAGEM 57. Planta Térreo, EE Jon Teodoresco em Itanhaém, projeto 1959 de Vilanova Artigas e Carlos Cascaldi. Fonte: http://www.archdaily.com.br/

80 
espacial, a relação entre os cheios e vazios, o aproveitamento e a simplificação da técnica construtiva do concreto armado influenciou as obras de escolas estaduais em seguida. A terceirização dos projetos de diferentes escritórios de arquitetura feita pelo IPESP, foi adotado pelos órgãos que viriam a se consolidar posteriormente como responsáveis pela construção escolar, isto é, o FECE, a CONESP e a FDE.

"A contratação de arquitetos autônomos é um fator que contribui à diversidade da produção arquitetônica e à economia de recursos humanos na entidade pública. $\ll^{9}$

Como Diretor de Projeto, Sílvio Breno, tinha contatos com todos os arquitetos que atuaram nas construções escolares. O FECE orientava os arquitetos autônomos, examinava e aprovava os projetos. Muitas vezes, ainda por falta de regras e normas estabilizadas, os projetos extrapolavam os custos. $\bigcirc$ que era bem especificado no inicio era a programação, as áreas e os terrenos das escolas. A escolha dos materiais ficava por conta dos arquitetos, o FECE costumava dizer "siga o seu bom senso «? meçava estabelecer diretrizes para a utilização dos materiais, foram também especificados as questões da manutenção. O FECE padronizava portões, portas, caixilhos, declínio da rampa etc.

\section{AS ESCOLAS INDUSTRIAIS}

Oarquiteto Geraldo Vespaziano Puntonifoitransferido para o FECE em 1962. Antes disso a sua primeira experiência na construção escolar foi através do Departamento de Ensino Profissional e o planejamento de escolas industriais em 1961.

»Em 1961 já começou o trabalho sobre as escolas industriais, que era uma equipe construída pelos arquitetos Lucio Grinover, Roberto José Goulart Tibau e Hélio de Queiroz Duarte. ${ }^{10}$

10 Entrevista, Marlene Picarelli, 04.07.2016

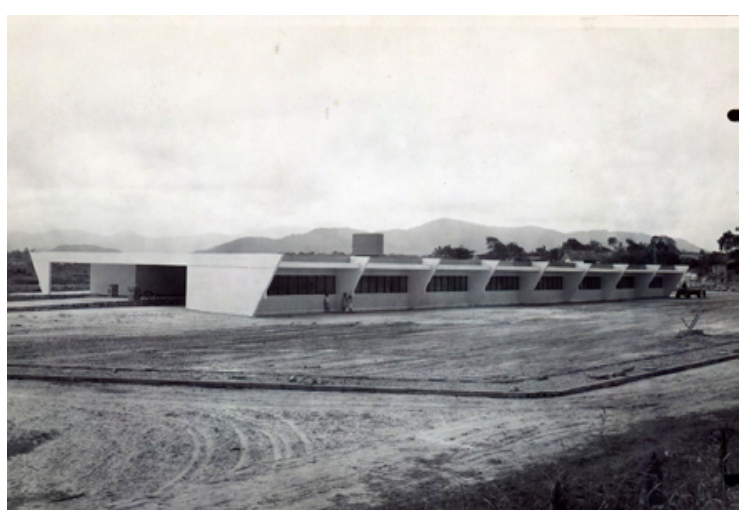

IMAGEM 58. EE Jon Teodoresco em Itanhaém, projeto 1959 de Vilanova Artigas e Carlos Cascaldi. Fonte: http://vilanovaartigas.com/cronologia 
Esse grupo foi complementado pelos jovens arquitetos Geraldo Vespaziano Puntoni, Sílvio Breno, Marlene Pirarelli e Arnaldo Tonissi, encarregados a desenvolver os projetos das escolas industriais. As construções das escolas industriais estavam de acordo com o desenvolvimento da indústria no Brasil. Era uma época que precisava de operários especializados, e o Governo queria atender essa demanda. Lúcio Grinover, coordenador desse grupo de planejamento, comentou a sua atuação como funcionário do SENAI nessa parceria.

»É que o governo queria construir escolas industriais, e quem estava fazendo escolas industriais era o SENAI. Então eles resolveram trabalhar juntos. Eu era Chefe de Obra do SENAI, daí eu fui desenvolver um plano de escolas (industriais). ${ }^{11}$

O SENAI tinha todas as informações para decidir onde, como e quando construir uma escola industrial e o Governo Carvalho Pinto, teve o

11 Entrevista, Lucio Grinover, 04.07.2016 objetivo de tornar mais atuantes as escolas profissionais, indispensáveis na preparação de mão de obra. Estas necessidades só puderam ser supridas com a colaboração das industrias e de seus órgãos com o Estado. O PAGE destacou esse interesse no trecho em seguida:

»É importante dar ao ensino médio uma equivalência nos seus ramos, valorizando o trabalho e incentivando nas crianças e nas famílias o interesse pelo ensino industrial e técnico. Mas, ao lado desta campanha esclarecedora, teremos que aparelhar o atual sistema de ensino profissional para atender às necessidades do trabalho no mundo moderno. ${ }^{12}$

Orquiteto Lucio Grinover, coordenou os estudos pré-liminares para a localização das novas escolas industriais. As demandas, mas também as industrias estabelecidas em certos lugares foram decisivas para as escolhas dos terrenos.

12 PAGE, Plano de Ação do Governo Carvalho Pinto, p.70 
»O que a gente fazia era, a partir de uma determinada cidade, construímos escolas em função daquilo que a cidade produzia. $\ll^{13}$

O SENAI foi convocado por causa da experiência, que ele acumulava ao longo da sua história. É de certo modo trágico, que o Departamento de Ensino Profissional não tinha verba para preparar as equipes assumindo as escolas industriais construídas. Consequentemente, muitas escolas ficaram vazias, pois não tinham funcionários qualificados. Segundo Geraldo Vespaziano Puntoni, muitas escolas foram destruídas e saqueadas antes de inaugurar. Sobretudo as máquinas das oficinas demandaram uma formação profissional para assumir a orientação. Em conclusão desse problema, quase todas as escolas viraram escolas técnicas sobre liderança do SENAI.

»Eu participei da reforma dos prédios que foram depredados. O único prédio da escola industrial que ficou intacto foi perto do Parque São Jorge,

13 Entrevista, Lucio Grinover, 04.07.2016 um bairro de portugueses. Eles tomaram conta da obra e do prédio. ${ }^{14}$

Os dois projetos das escolas industriais em Jundiaí e Araçatuba, desenvolvidos pelo arquiteto Geraldo Vespaziano Puntoni, em conjunto com a equipe do grupo do Departamento de Ensino Profissional demonstram, tanto em Araçatuba, como em Jundiaí projetos de grande dimensões. Embora que o programa estabelecido pelo Governo Carvalho Pinto e toda a sistematização do PAGE era eminentemente precisa e técnica, tinham uma grande liberdade projetual. Porém, podemos relativizar isso, através dos estudos em seguida com o projeto do concurso para a Escola Técnica Federal de São Paulo, na qual o arquiteto Geraldo Vespaziano Puntoni, atuou como arquiteto autônomo e foi o primeiro classificado (1965). Vale a pena ressaltar, que pressões políticas das prefeituras ou do governo para acrescentar ambientes específicos poderiam ter ocorrido nas duas escolas

14 Entrevista, Geraldo Vespaziano Puntoni, 04.07.2016

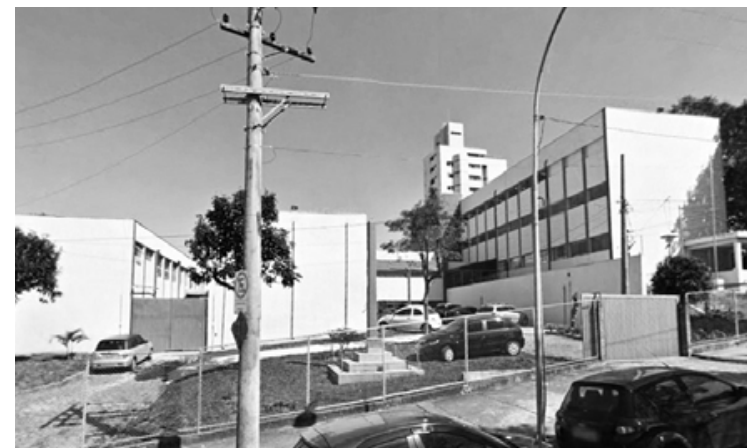

IMAGEM 59. Escola Industrial de Jundiaí, EE Doutor Antenor Soares Gandra, Jundiaí, São Paulo, 1961, Fonte: Google Street View 


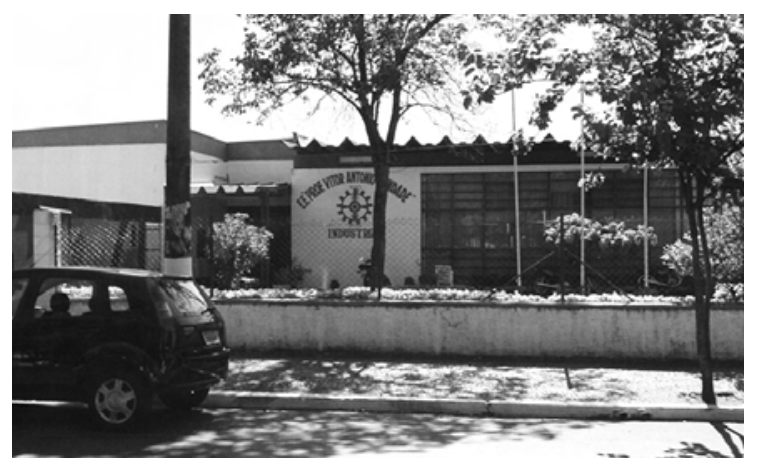

$\ldots+2$
IMAGEM 60.Escola Industrial de Araçatuba, EEPSG Prof. Victor Antonio Trindade, São Paulo, 1961, Fonte: http://mapio.net/s/29506820/ analisadas. Um dos critérios para os projetos das escolas era minimizar a manutenção, principalmente pela quantidade de escolas construídas, e a diminuição dos custos da obra. Com isso depara -se o material usado em sua forma bruta como o concreto aparente pintado e alvenaria revestida e pintada. A solução estrutural que predomina é o concreto armado. Sem dúvidas, a economia na construção foi marcante, ao mesmo tempo as soluções simples puderam trazer um aspecto sobre a clareza construtiva como por exemplo, a ausência de revestimento, evidencia estrutural ou tubulações aparentes, etc.. Os alunos podem compreender facilmente todos os componentes da arquitetura, seus »porques«, e seus »como«. Arquitetura assumiu uma função formadora e pedagógica.

As duas escolas contam com 18 (Jundiaí) e 24 (Araçatuba) salas de aula. $\bigcirc$ projeto de Jundiaí tem uma biblioteca, a mesma não existe no projeto de Araçatuba. Provavelmente isso se deva à forma com que o ambiente biblioteca era entendido. $\bigcirc$ projeto de Araçatuba poderia ter contado com uma área no galpão destinado a biblioteca. Na organização do programa das duas escolas percebe-se, que as duas propostas tratam as oficinas de uma forma similar. As oficinas (acentuado em cinca) se encontram isoladas dos outros usos como a administração ou das salas de aula (acentuado em vermelho), somente a sala de aula, vinculada ao ensino da respectiva oficina encontra-se conectada diretamente. Essa separação fez sentido para evitar uma interferência auditiva durante as aulas. Mesmo assim, a composição da volumetria das oficinas em relação com os volumes principais era bem diferente em ambas as situações. Enquanto o volume das oficinas e o volume principal em Araçatuba criaram um »L«, o volume das oficinas em Jundiaí foi colocado em paralelo ao volume principal, criando assim um corredor estreito entre os dois volumes. $O$ corredor acaba-se sobrepor com o galpão no centro do edifício principal. No caso da composição »L« em Araçatuba, a organização retangular acabou criando um pátio para as duas quadras de múltiplo uso. Os vazios existentes nos dois edifícios 


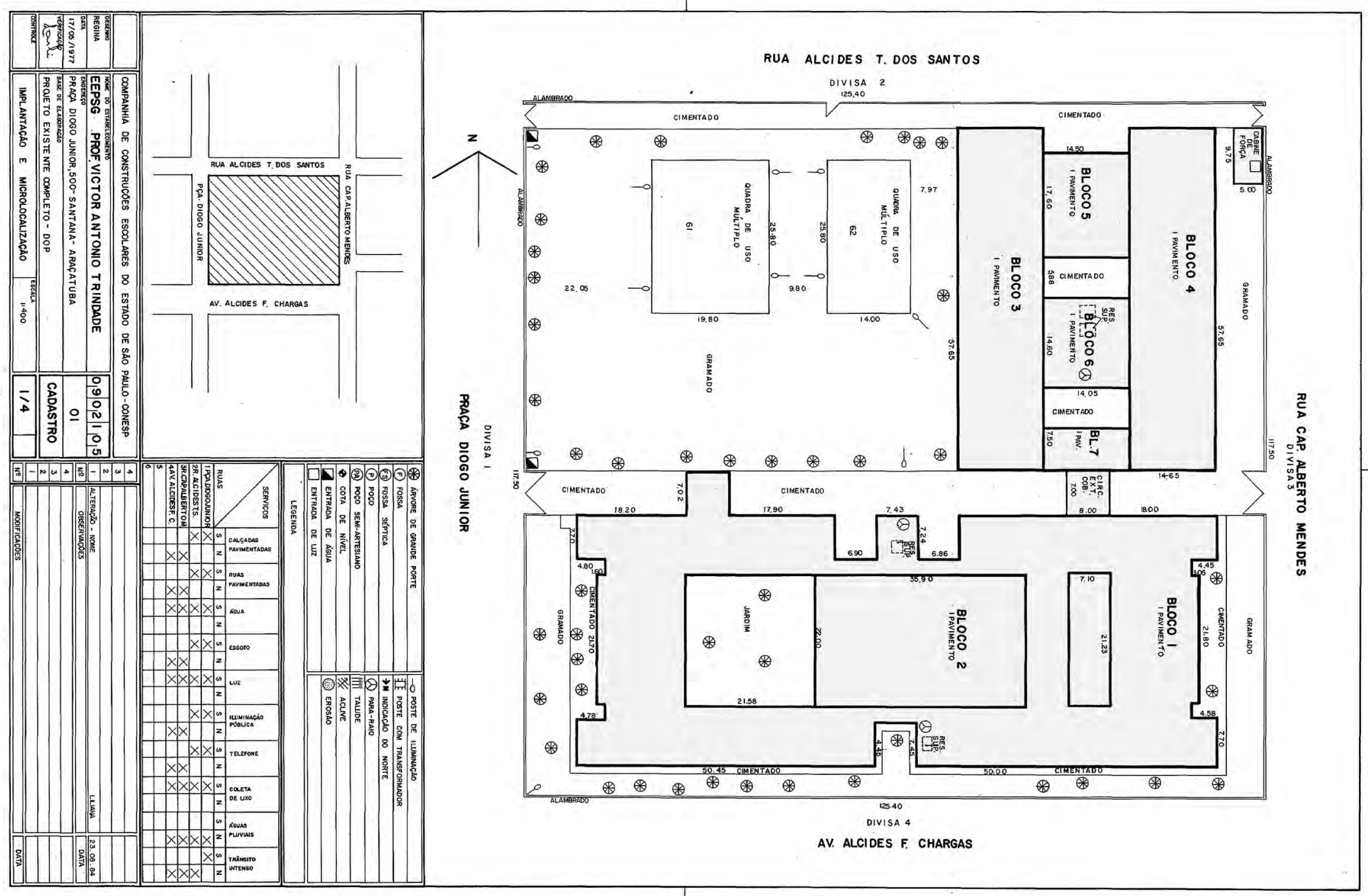

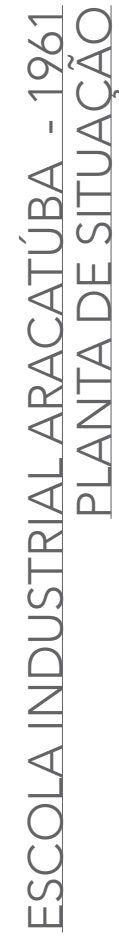

IMAGEM 61. Levantamento Escola Industrial de Araçatuba, EEPSG Prof. Victor Antonio Trindade, São Paulo, 1961, Material: Acervo da FDE, São Paulo 
멈

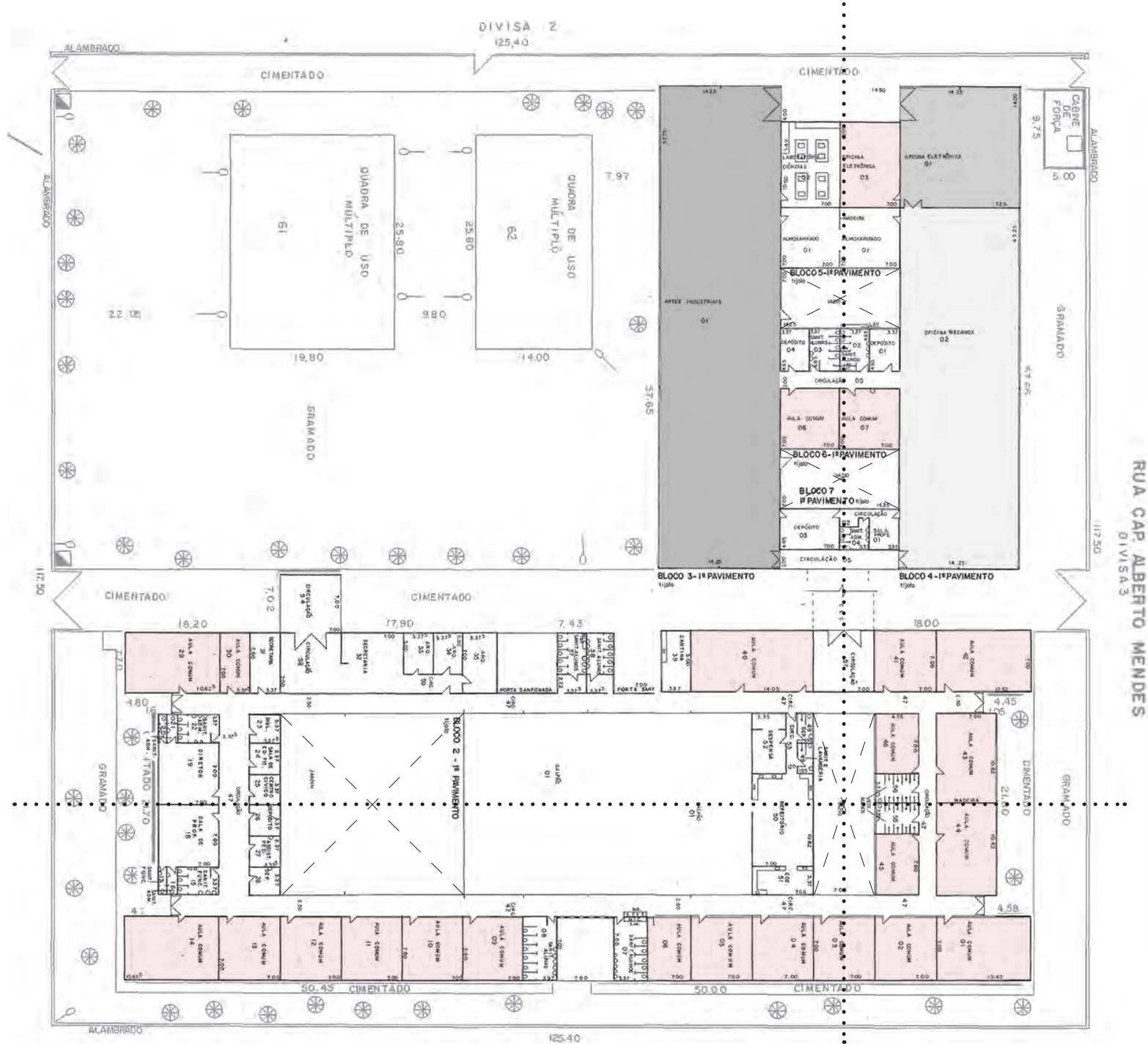

IMAGEM 62. Levantamento Escola Industrial de Araçatuba, EEPSG Prof. Victor

Antonio Trindade, São Paulo, 1961, Material: Acervo da FDE, São Paulo 


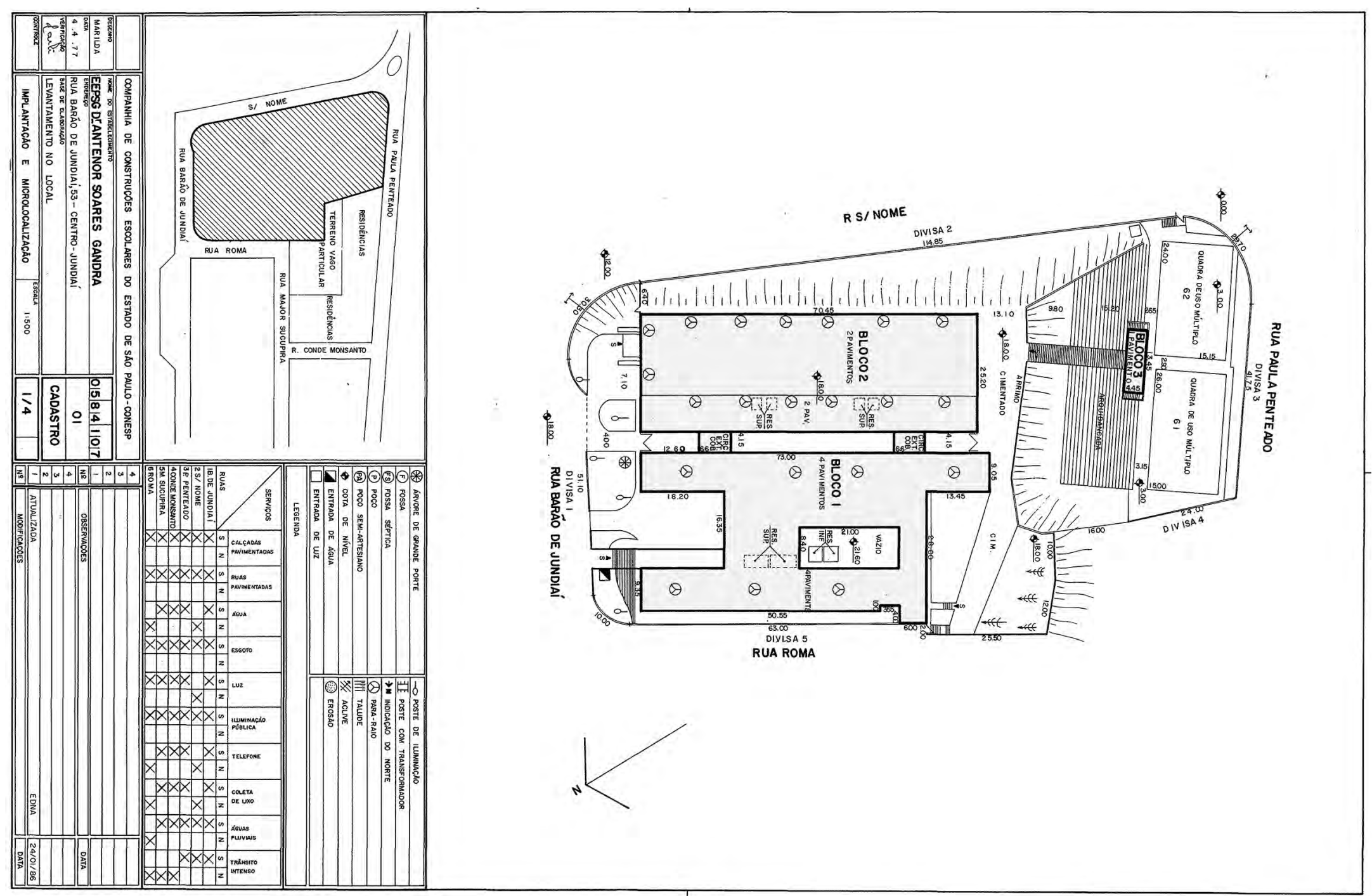

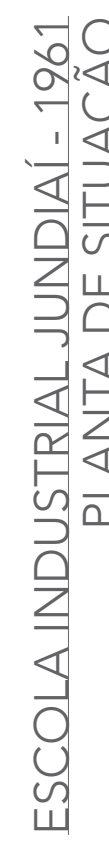

IMAGEM 63. Levantamento Escola Industrial de Jundiaí, EE Doutor Antenor Soares Gandra, Jundiaí, São Paulo, 1961, Material: Acervo da FDE, São Paulo 
붐

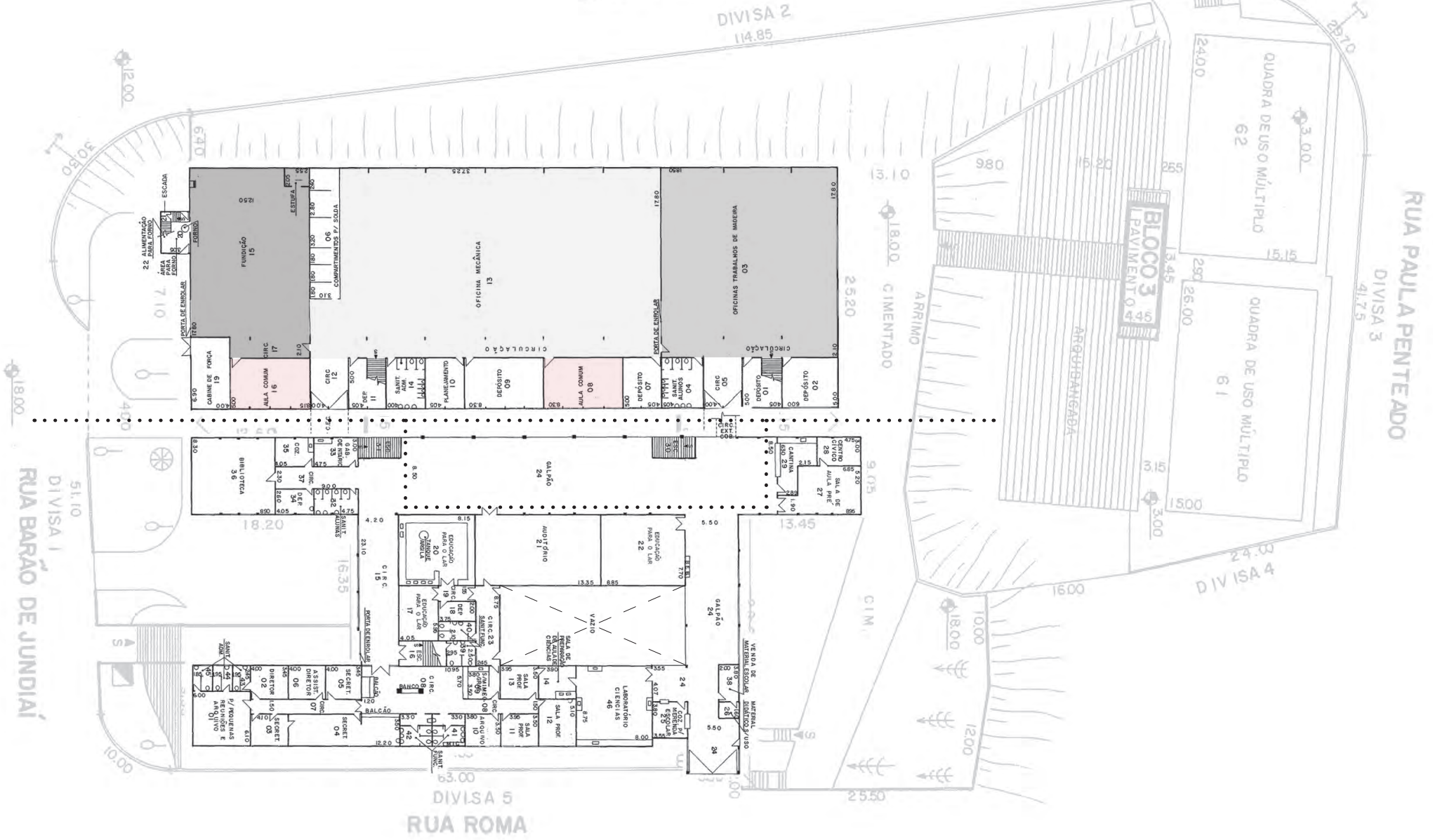

IMAGEM 64. Levantamento Escola Industrial de Jundiaí, EE Doutor Antenor So-

ares Gandra, Jundiaí, São Paulo, 1961, Material: Acervo da FDE, São Paulo 


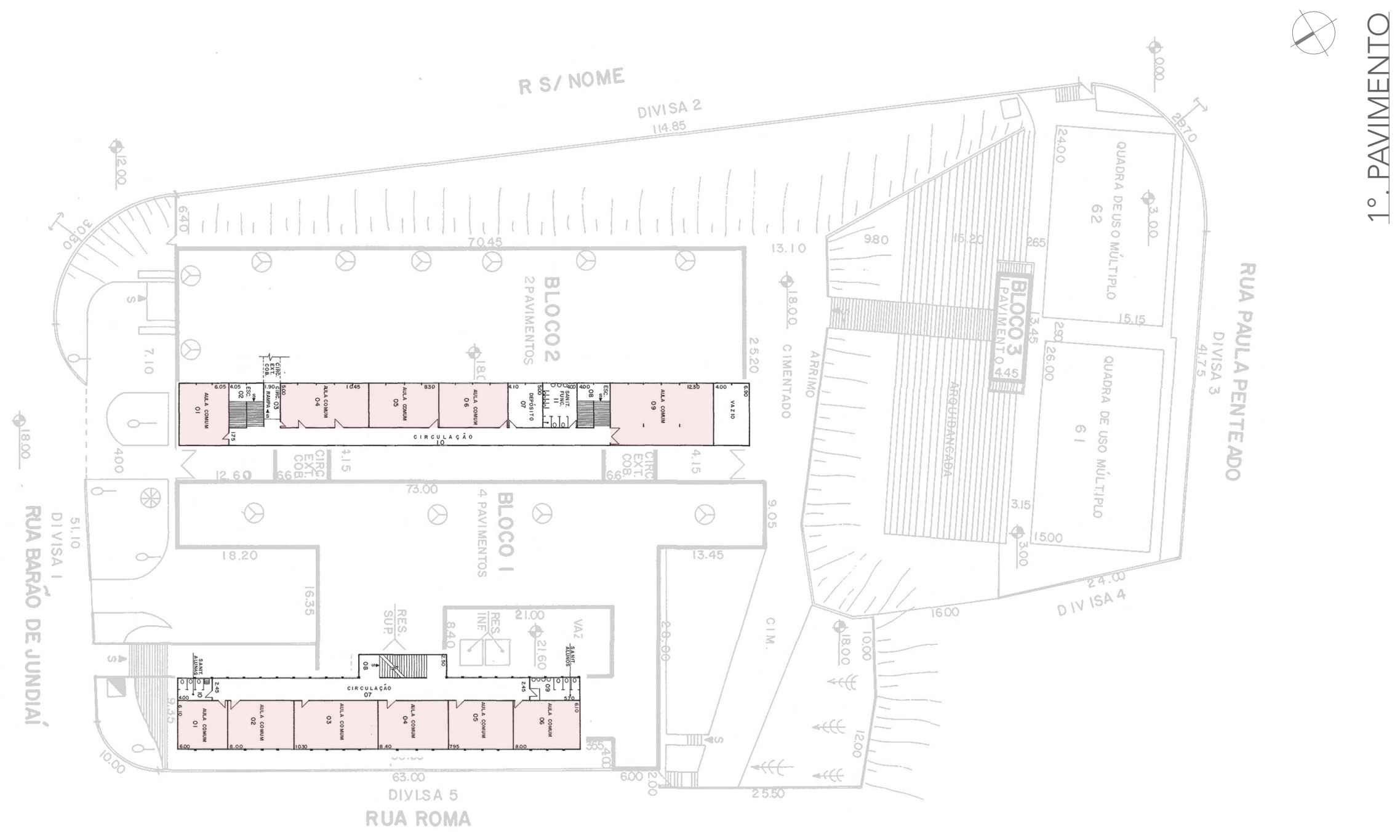

IMAGEM 65. Levantamento Escola Industrial de Jundiaí, EE Doutor Antenor Soares Gandra, Jundiaí, São Paulo, 1961, Material: Acervo da FDE, São Paulo 


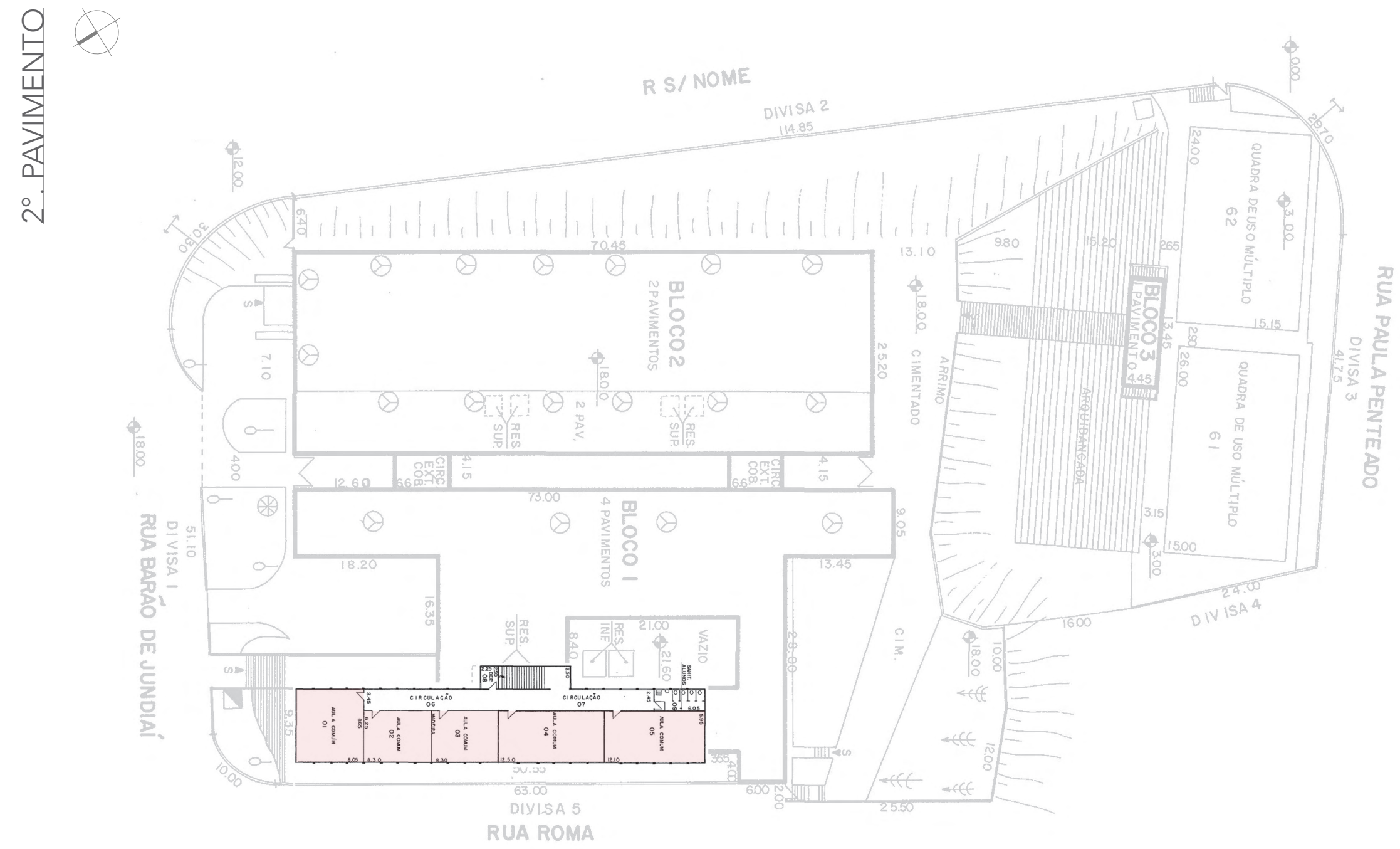

IMAGEM 66. Levantamento Escola Industrial de Jundiaí, EE Doutor Antenor Soa-

res Gandra, Jundiaí, São Paulo, 1961, Material: Acervo da FDE, São Paulo 
estabelecem dois eixos que encontram-se no pátio do volume principal.

A verticalidade das escolas tem relação direta com a área do terreno e número de salas de aula. A maioria das escolas construídas durante o Governo Carvalho Pinto são térreas conforme dados levantados na pesquisa do Flávio Handlich $^{15}$. Isso justifica-se pela relação dos terrenos proporcionalmente grandes e a área construída das escolas. Provavelmente os arquitetos tinham liberdade na escolha da verticalidade das edificações. Evidentemente a decisão esteve condicionada às ideias projetuais, como a implantação do projeto, a relação do projeto com a topografia ou os estudos sobre os cheios $e$ vazios. O projeto da Escola Técnica Federal de São Paulo, localizada na Rua General Júlio M. Salgado no Centro de São Paulo, foi um concurso, no qual o arquiteto Geraldo Vespaziano Puntoni se posicionou como arquiteto autôno-

15 Flávio Handlich, "As Escolas do IPESP: Projetos de Edifícios Escola res produzidos para o Instituto de Previdência do Estado de São Paulo de 1959 a1962”. São Paulo: FAU USP, 2009 (dissertação de mestrado). p. 47. mo. $\bigcirc$ concurso foi realizado em 1965, ou seja, quatro anos depois da sua experiência com as escolas industriais. Portanto interessa, como o arquiteto assumiu esse exercício de projeto, livre de todas as circunstâncias políticas. Para retomar a discussão anterior, percebe-se, que o arquiteto propôs uma escola verticalizada, em forma de uma lâmina estendida. A verticalização da escola proporcionou mais espaço livre no terreno e permitiu a construção de uma praça com espelhos d'água, que cria de um lado um convite para entrada da escola, e por outro lado um gesto generoso para a vida urbana em torno da escola. A perspectiva em seguida demonstra claramente a intenção da praça, de criar um lugar de interface entre escola e cidade. A ideia da praça é estendida ainda através do térreo da escola, que é praticamente permeável, e somente ocupada através dos volumes da administração, do auditório, e das escadas de circulação. Os pilotís fortalecem ainda mais a ideia do fluxo contínuo. A estrutura em balanço, com apoios duplo no centro em concreto armado, permitiu uma planta livre nas divisórias 

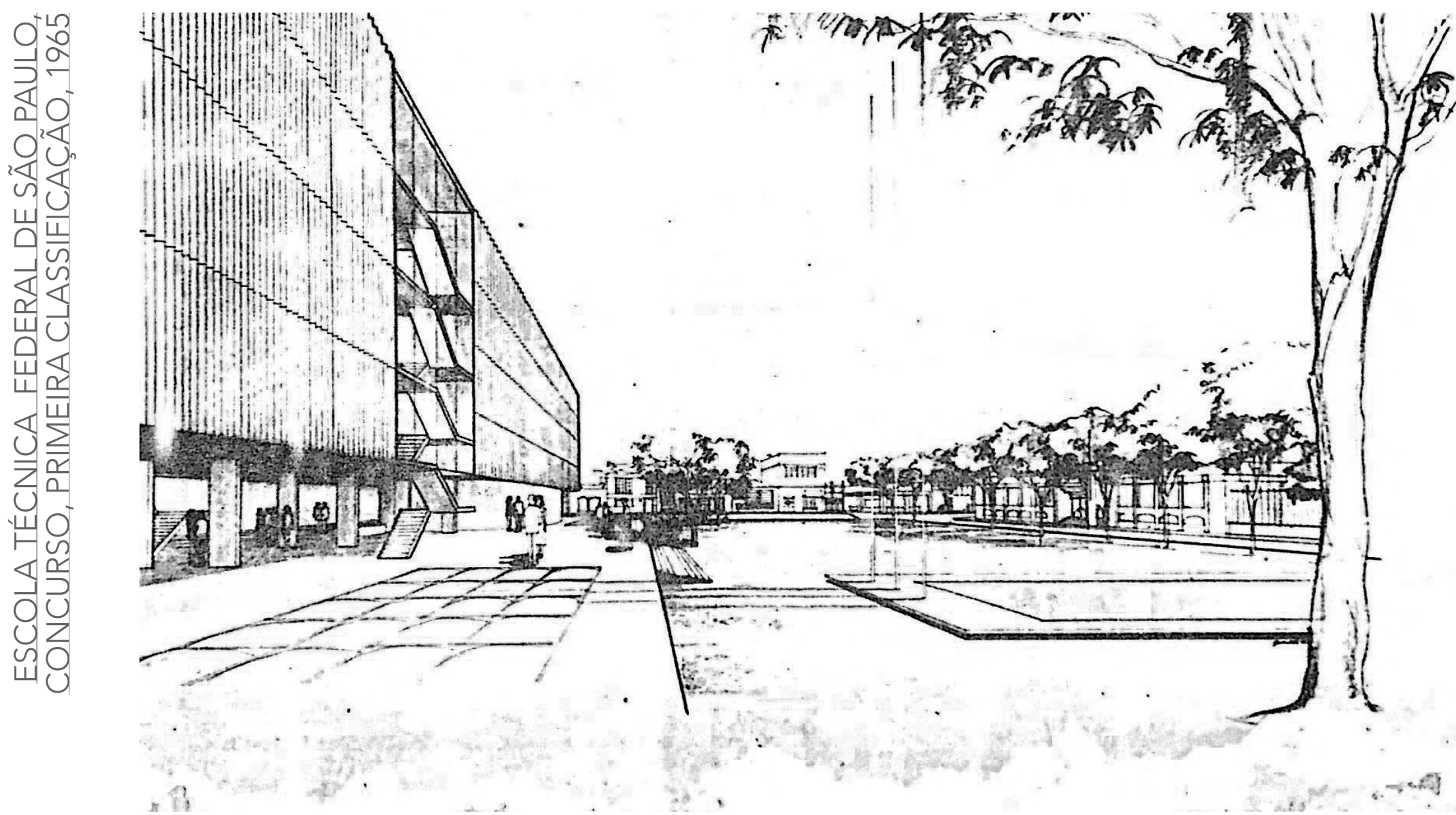

IMAGEM 67. Perspectiva, Escola Técnica Federal de São Paulo, Rua General Júlio M. Salgado, 234, São Paulo, Concurso, 1965, Fonte Arquivo Geraldo Vespaziano Puntoni 


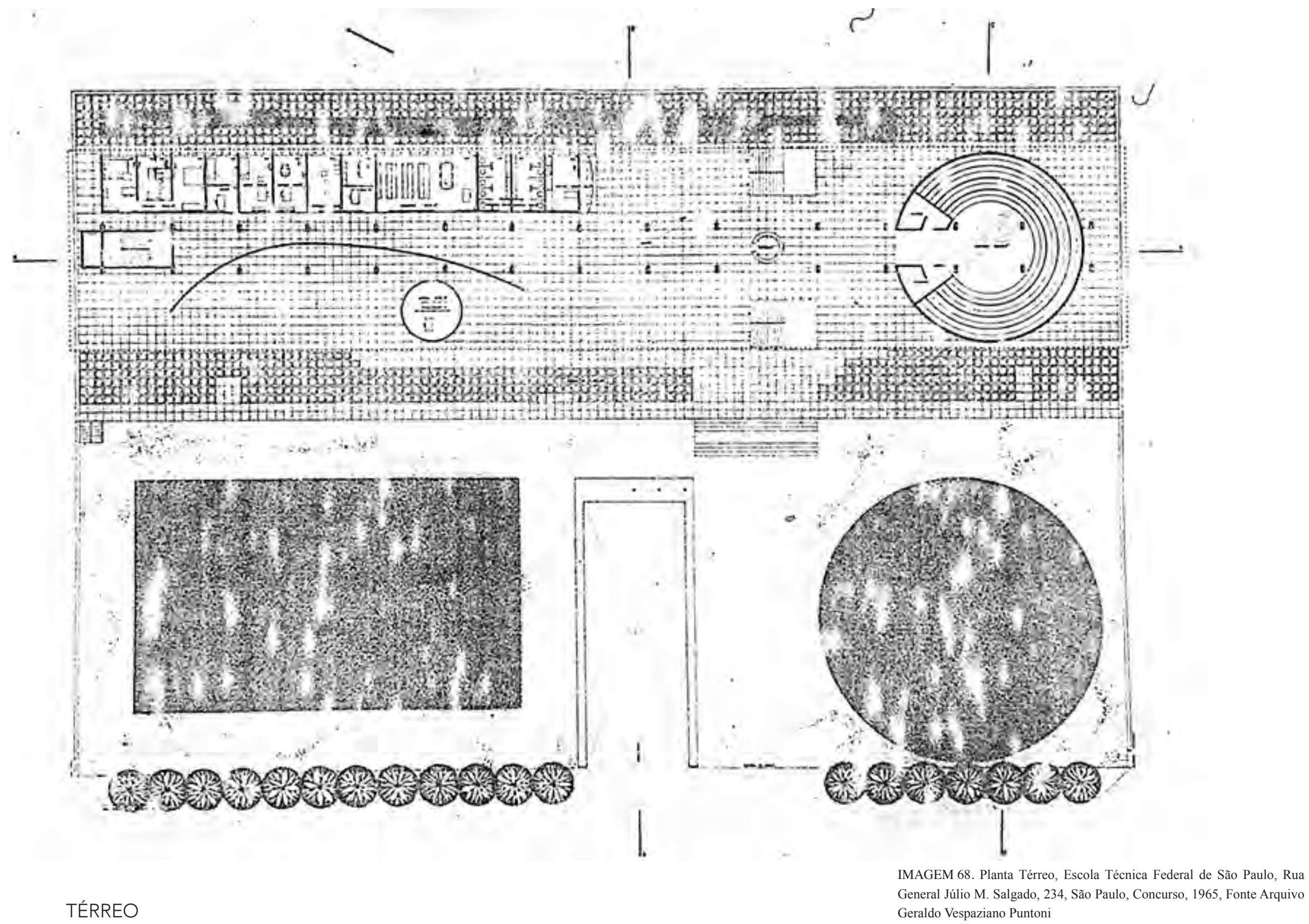




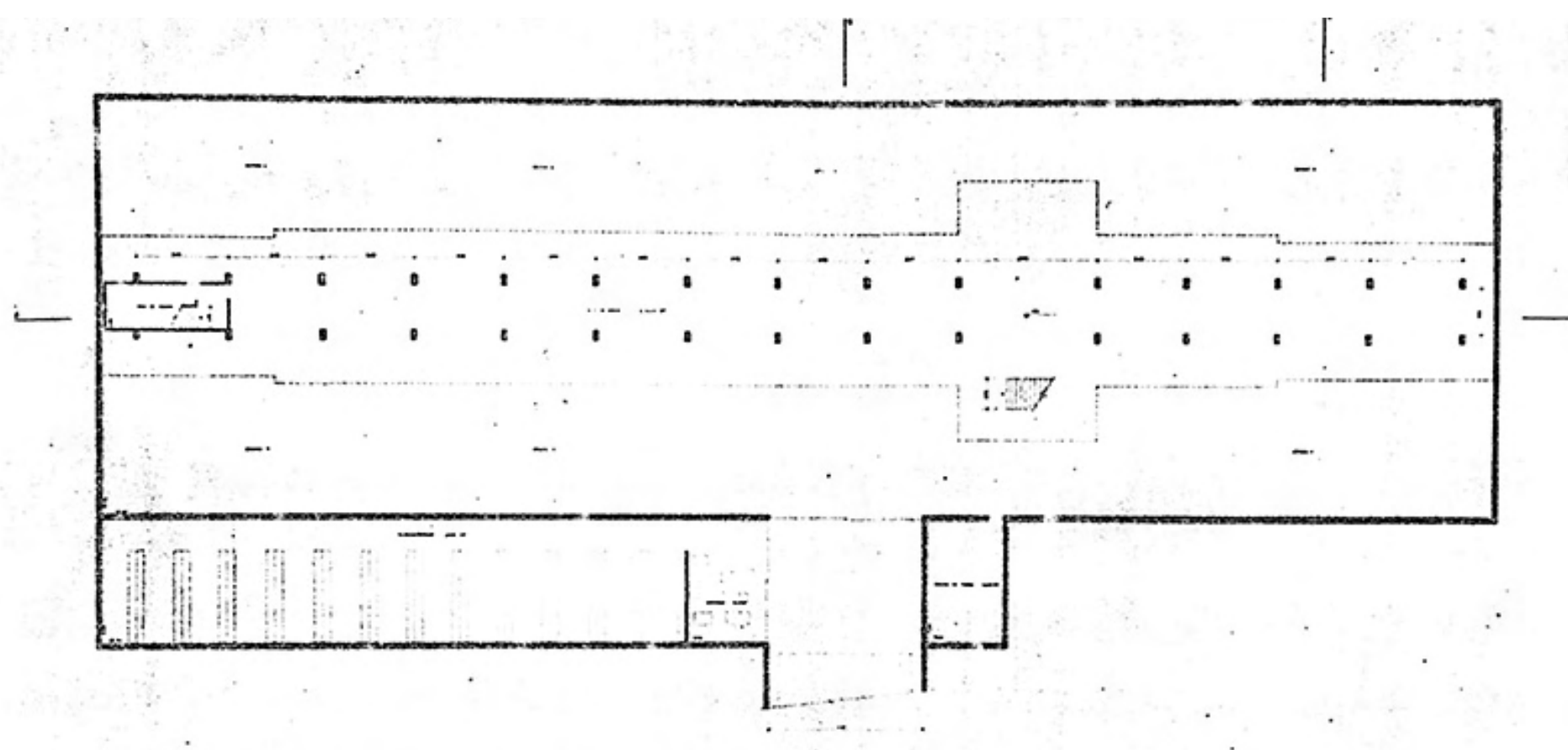

nom sons. 


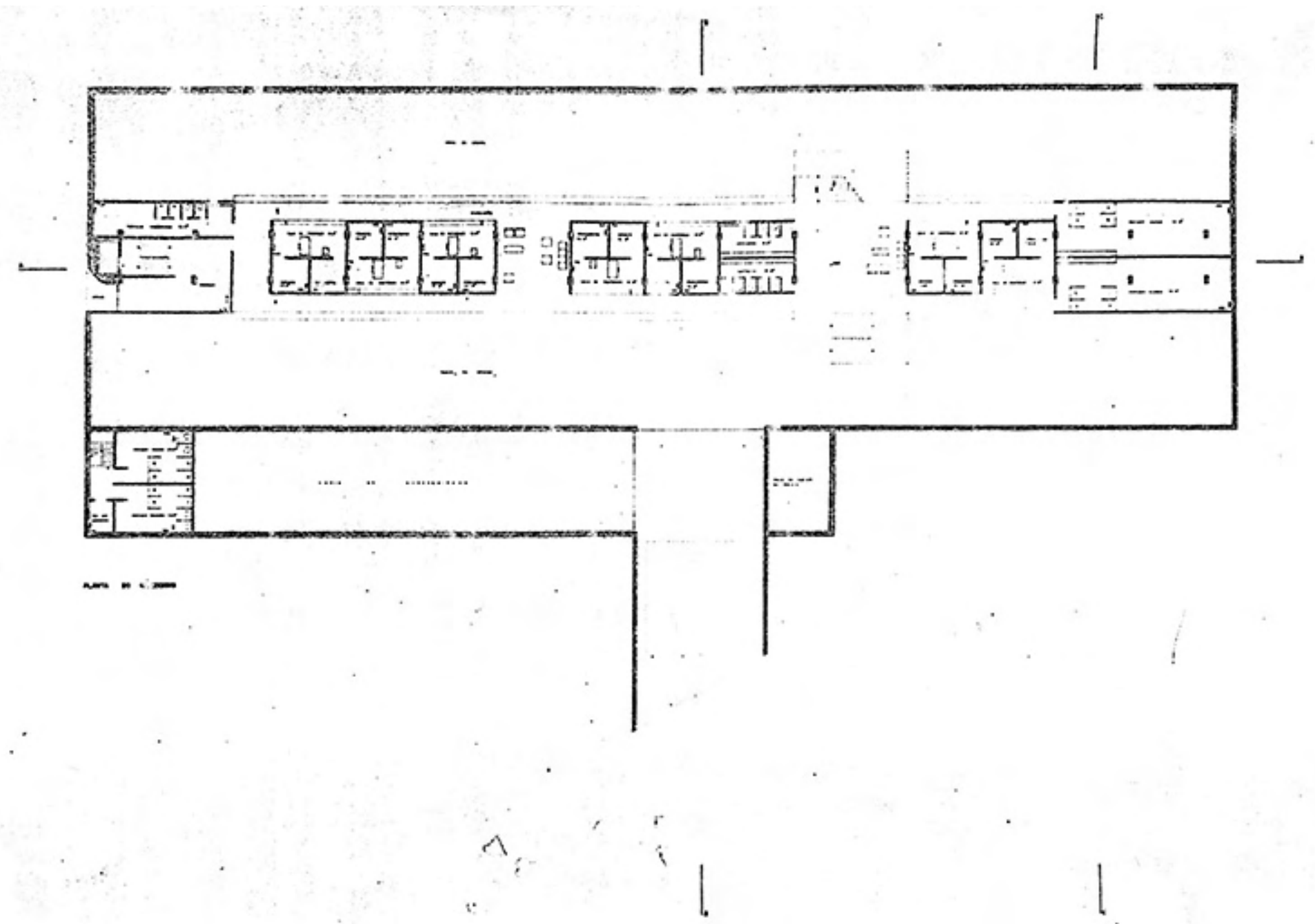

$-1^{\circ}$. SUBSOLO

IMAGEM 70. Planta, - $1^{\circ}$ Subsolo, Escola Téenica Federal de São Paulo, Rua General Júlio M. Salgado, 234, São Paulo, Concurso, 1965, Fonte: Arquivo Geraldo Vespaziano Puntoni 


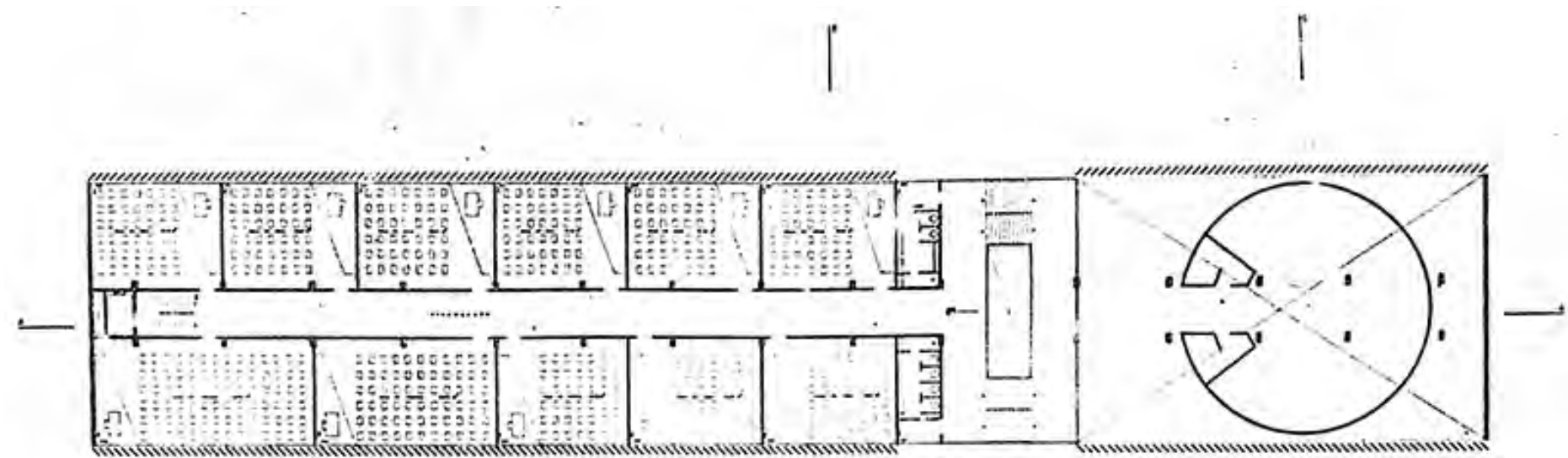

nam - . . - ne..

1․ PAVIMENTO

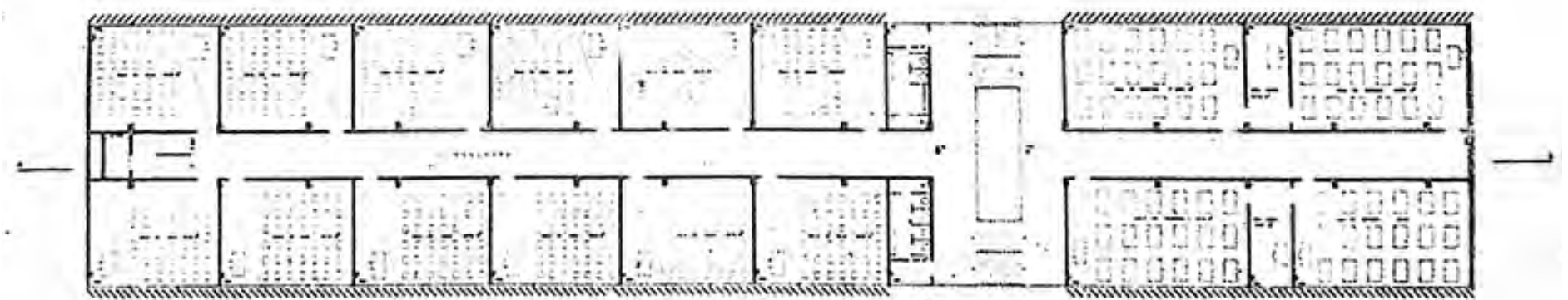

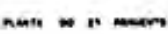
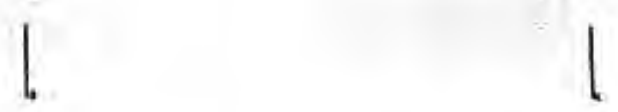

$2^{\circ}$. PAVIMENTO

IMAGEM 71. Planta, $1^{\circ}$. Pavimento/ $2^{\circ}$. Pavimento, Escola Técnica Federal de São Paulo, Rua General Júlio M. Salgado, 234, São Paulo, Concurso, 1965, Fonte: Arquivo Geraldo Vespaziano Puntoni 


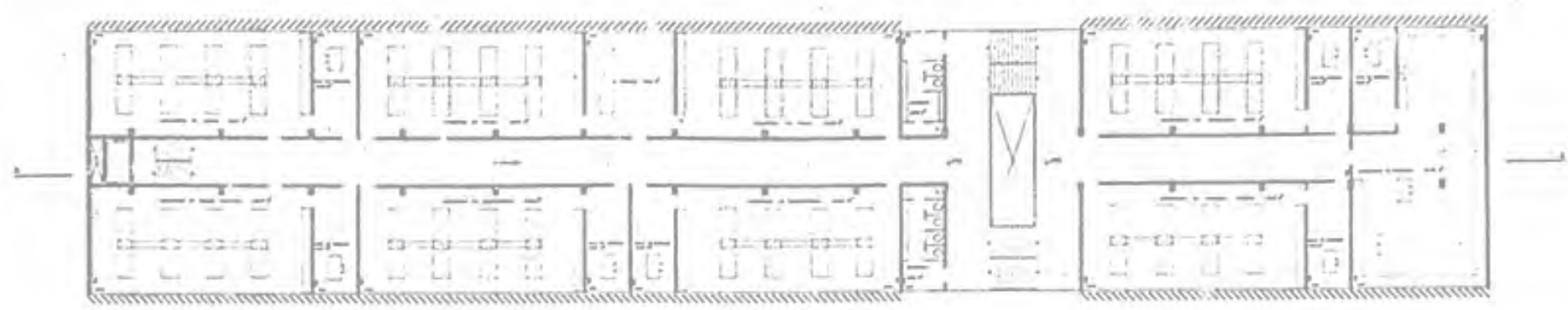

3․ PAVIMENTO
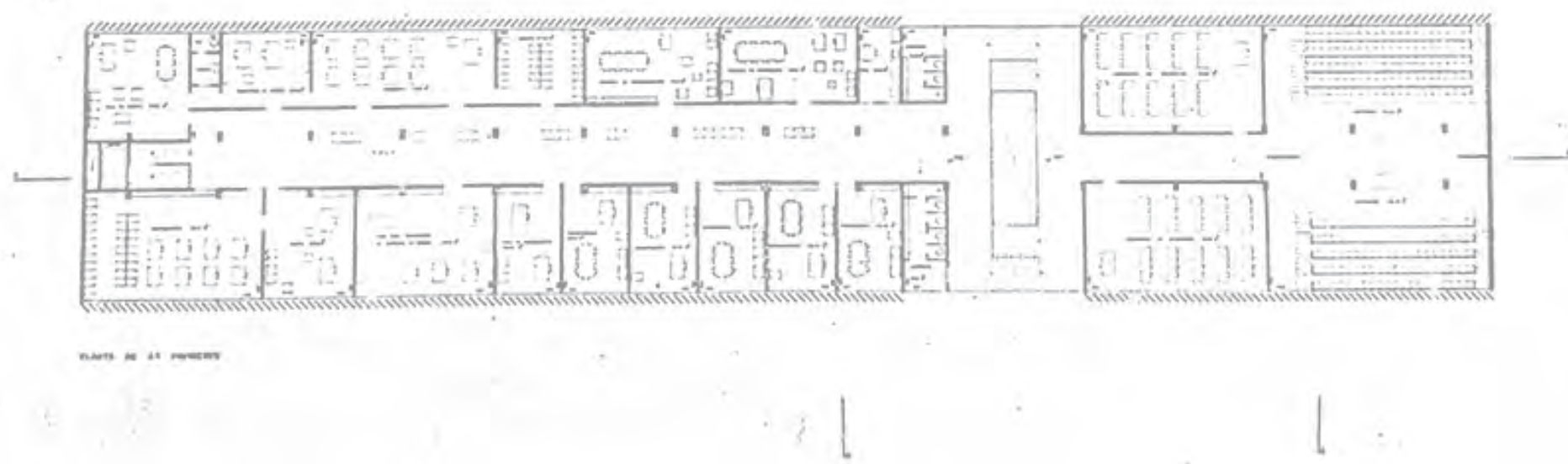

IMAGEM 72.Planta, $3^{\circ}$. Pavimento/ $4^{\circ}$. Pavimento, Escola Técnica Federa de São Paulo, Rua General Júlio M. Salgado, 234, São Paulo, Concurso, 1965, Fonte: Arquivo Geraldo Vespaziano Puntoni 


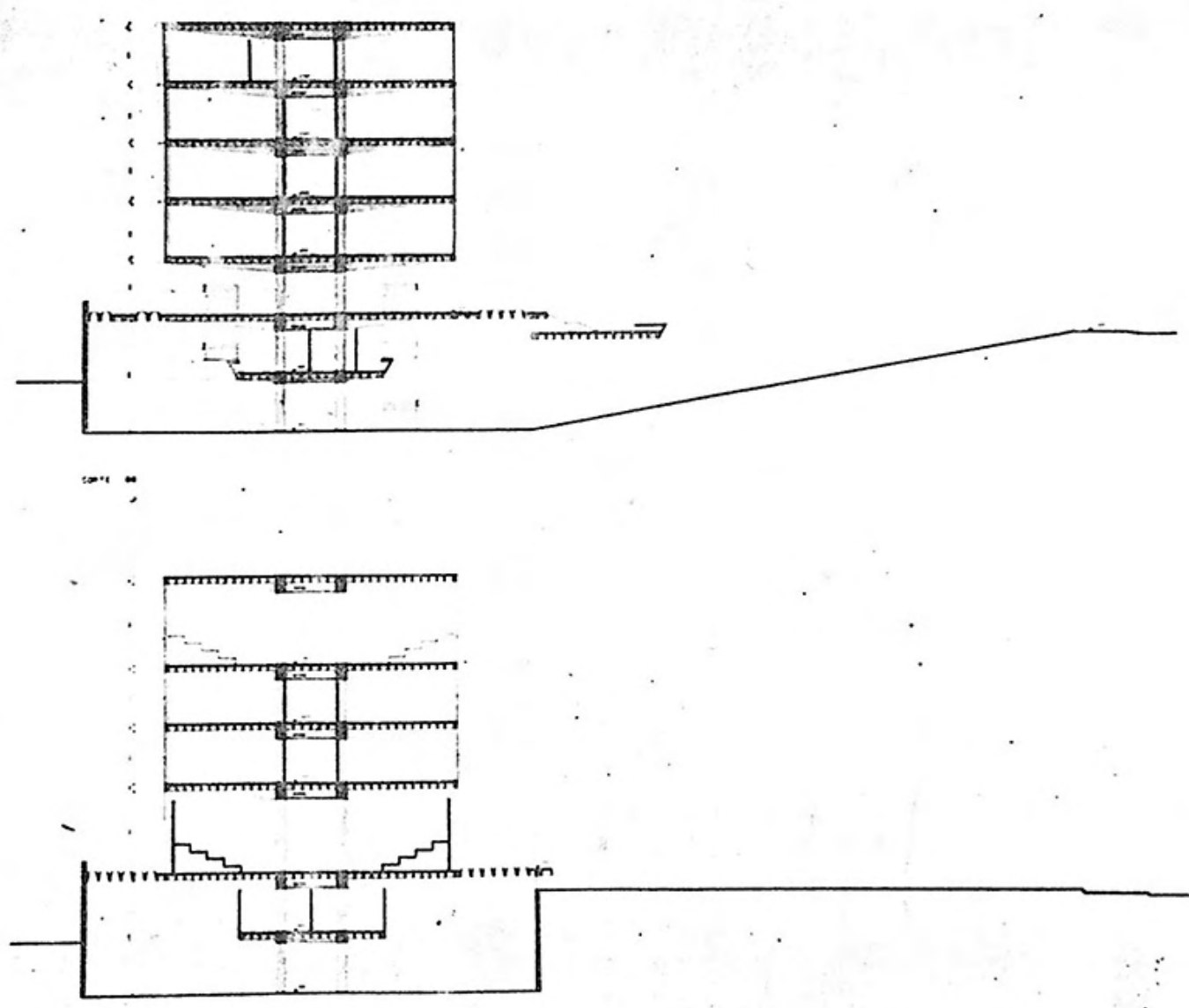

CORTES TRANSVERSAIS

IMAGEM 73. Cortes Transversais, Escola Técnica Federal de São Paulo, Rua General Júlio M. Salgado, 234, São Paulo, Concurso, 1965, Fonte: Arquivo Geraldo Vespaziano Puntoni 


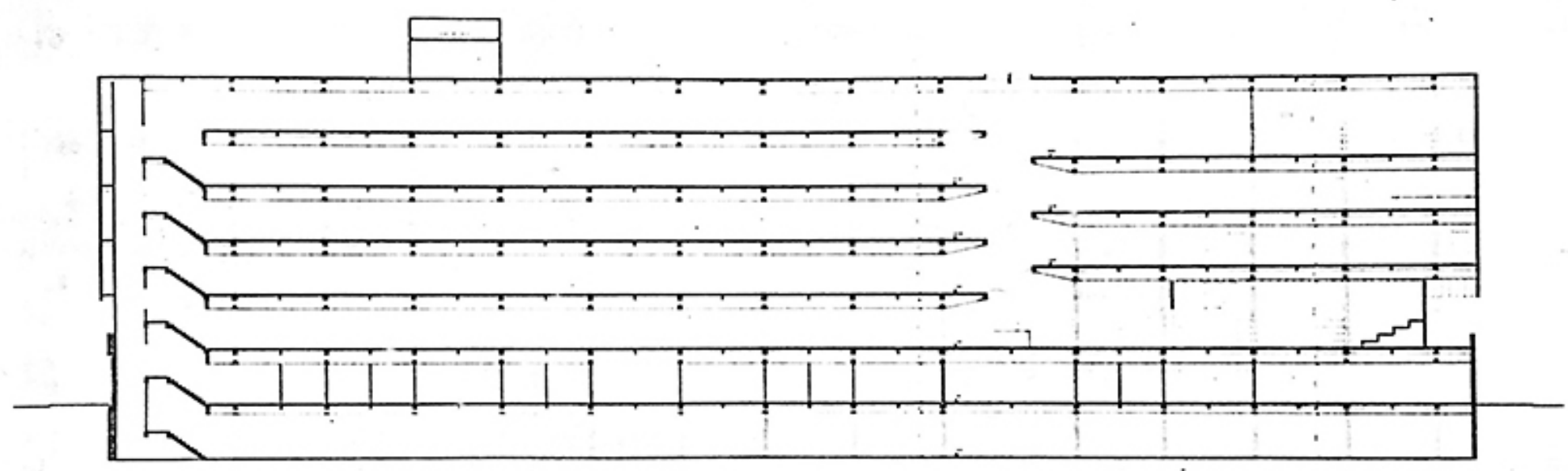

s......

CORTE LONGITUDINAL

IMAGEM 74. Corte Longitudinal, Escola Técnica Federal de São Paulo, Rua General Júlio M. Salgado, 234, São Paulo, Concurso, 1965, Fonte: Arquivo Geraldo Vespaziano Puntoni 


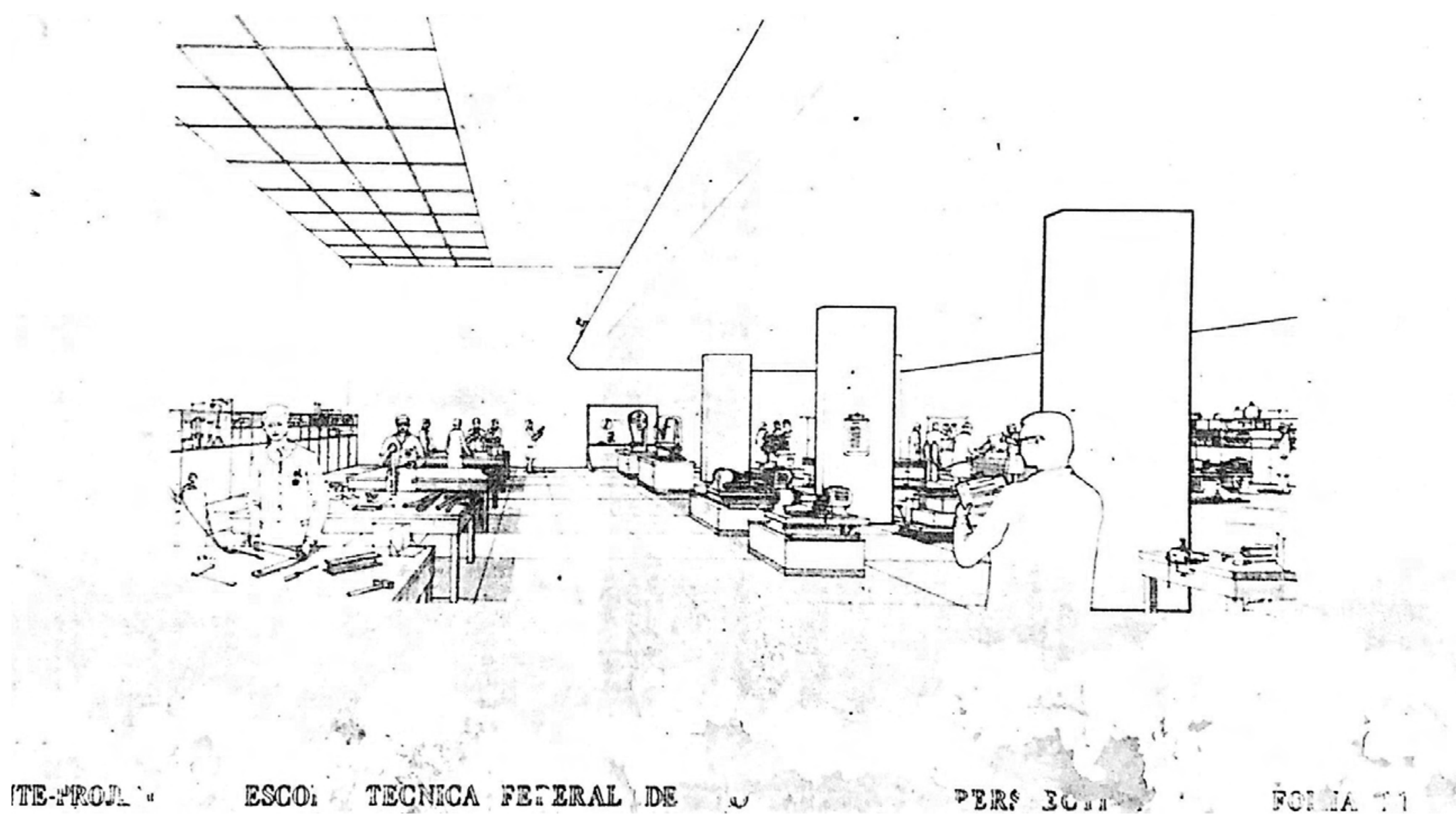

IMAGEM 75. Perspectiva, Escola Técnica Federal de São Paulo, Rua Ge-

neral Júlio M. Salgado, 234, São Paulo, Concurso, 1965, Fonte: Arquivo

Geraldo Vespaziano Puntoni 
das salas, laboratórios e todos os outros usos no andar de cima. A clareza da estrutura proporcionou uma fachada livre, onde os brises permitem a ventilação, uma luz indireta e a estruturação da fachada. O projeto do arquiteto Geraldo Vespaziano Puntoni demonstra com muita clareza as ideias da arquitetura moderna, que foram incorporadas ao longo do seu caminho. A sua formação universitária, sua primeira atuação como arquiteto autônomo, as experiências no DOP e as obras das escolas industriais projetadas fazem evidentemente parte dessa formação continua.

\section{GINÁSIO ESTADUAL VOCACIONAL „CÂNDIDO PORTINAR|«EM BATATAIS}

A experiência dos Ginásios Vocacionais teve seu início de funcionamento em 1962. A experiência vocacional foi uma proposta de educação experimental, necessitando assim aplicar as propostas e, somente em seguida, elaborar um documento que pudesse trazer os parâmetros de funcionamento e organização da experiência. Assim, somente em 1968 a escola apresentou seus planos pedagógicos.

»O projeto, porém, de forte inspiração no novo humanismo, centrado no homem concreto, volta-se ao homem brasileiro e contempla a formação integral do educando, o seu autoconhecimento e a descoberta da vocação. $«^{16}$

Em 1969, no auge repressivo da ditadura militar, os Ginásios Vocacionais foram extintos, e denominados subversivos. $\bigcirc$ projeto da escola vocacional desapareceu, no entanto, deixou as suas marcas na discussão do ensino público até hoje, como demonstrou por exemplo a publicação recente da Esméria Rovai que organizou o livro »Ensino Vocacional. Uma pedagogia atual«, lançado em 2005.

Através do FECE $O$ arquiteto Geraldo Vespaziano Puntoni participou, em 1961 no projeto de reforma, ampliação e adaptação do Edifício

16 FERREIRA, Daniela Gomes de Albuquerque, Ginásio Estadual Vocacional »Cândido Portinari« de Batatais. Universidade de São Paulo Faculdade de Educação, São Paulo, 2007, p. 27.

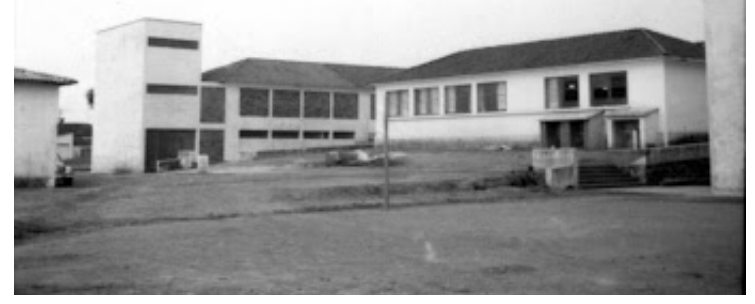

IMAGEM 76. Prédio do Ginaásio Vocacional »Cândido Portinari« (1962). Fonte: Arquivo do GVCP. 


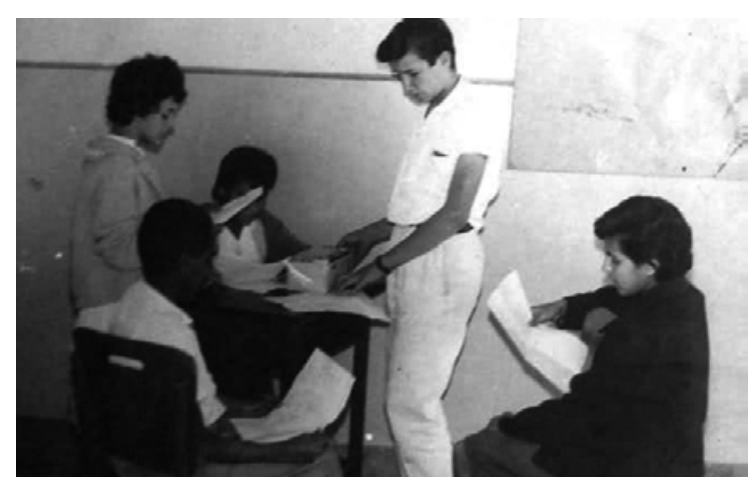

do Ginásio Vocacional »Cândido Portinari« em Batatais. Podemos imaginar que esse trabalho trouxe discussões interessantes na interface entre arquitetura, sociedade e educação. Que provavelmente rebateu nas suas posturas como arquiteto e funcionário público no pensamento projetual de uma escola como um todo.

» [...] o aluno tinha a oportunidade de vivenciar uma atividade em diferentes áreas como por exemplo: Cantina Escolar, Banco Escolar e Contabilidade. A cantina por exemplo era dirigida e organizada por alunos [...] seria uma forma de preparar o jovem para a vida em comunidade, a fim que ele compreendesse o funcionamento e a organização da sociedade da época. «

O FECE participou ativo na reestruturação dos conceitos pedagógicos da época. Segundo Sílvio Breno foram chamados representantes de diversas escolas, que eram consideradas exemplares na época no Estado de São Paulo, como por exemplo um pedagogo do Ginásio Vocacional de Brooklyn. Uma outra parceria aconteceu com a Escola Experimental da Lapa, que se especializou na reformulação do ensino Pré Escolar. Teresina Fran, uma educadora importante da época, trabalhou em conjunto com o FECE no desenvolvimento da programação pedagógica e seu rebatimento no espaço arquitetônico. Um dos resultados dessa discussão foi um plano para adotar em todas as Escolas Pré e Pré-Primárias uma oficina de artes industriais. Com isso foi necessário localizar, dentro da programação das escolas existentes, o lugar mais propício para inserir esse novo programa. Pela observação dos aspectos levantados o arquiteto Sílvio Breno foi encarre gado de transferir todos os projetos das Escolas do Arquivo do DOP para o FECE. Isso foi um desafio, pois não existia um arquivo organizado no DOP e até hoje existem grande lacunas na documentação das escolas existentes.

De qualquer forma, a discussão sobre a programação pedagógica foi uma experiência eminentemente importante para a carreira do arquiteto e funcionário público Geraldo Vespaziano Pun- 
toni. Talvez não seja por acaso, que ele é, ainda hoje, Professor ativo em diversas Universidades. $\bigcirc$ arquiteto dedicou grande parte da sua vida ao ensino, e provavelmente essa decorrência está vinculada com as experiências do FECE. Parece até uma conclusão dessa carreira profissional, que a faculdade (Associação Escola da Cidade) onde ele ensina hoje, é a escola que ele, entre outros professores, mesmo criou. A pesquisa não passaria despercebida desse assunto, pois o ensino é uma das partes significativas na carreira do arquiteto e servidor público em questão. O Ginásio da Escola Vocacional tem uma grande contribuição na reformulação do ensino, que influenciou as posturas do arquiteto e educador Geraldo Vespaziano Puntoni.

\section{AS ESCOLAS RURAIS}

Durante o governo do Adhemar de Barros (1962 a 1965) foi feito um levantamento importante para o desenvolvimento rural: O Plano para as escolas rurais. Os primeiros estudos foram feitos pela Clementina de Ambrosio. Em de- corrência do estudo, era necessário verificar os terrenos, onde as escolas rurais iriam ser implantadas. Tinham terrenos afastados onde o acesso era muito difícil. Segundo Sílvio Breno, as vezes nem era possível chegar de carro. A equipe do FECE visitou cidade por cidade, para avaliar suas necessidades e as demandas.

»Geralmente as prefeituras organizaram grandes jantares nas praças da cidade para comemorar a chegada dos arquitetos da capital. ${ }^{17}$

O projeto da escola de Clementina de Ambrosio, segundo Sílvio Breno, lembrava a Casa Bandeirante. Era um projeto que possibilitava com facilidade as ampliações e separações das salas de aula. A sala de aula tinha uma lousa dos dois lados da sala. Era comum nas escolas rurais ter somente uma professora para ensinar turmas diferentes ao mesmo tempo.

17 Entrevista, Sílvio Breno de Souza Santos, 15.11.2015
1. Residência

2. Sanitários

3. Recreação / Sala de aula / Público - Serviços

4. Sala de aula
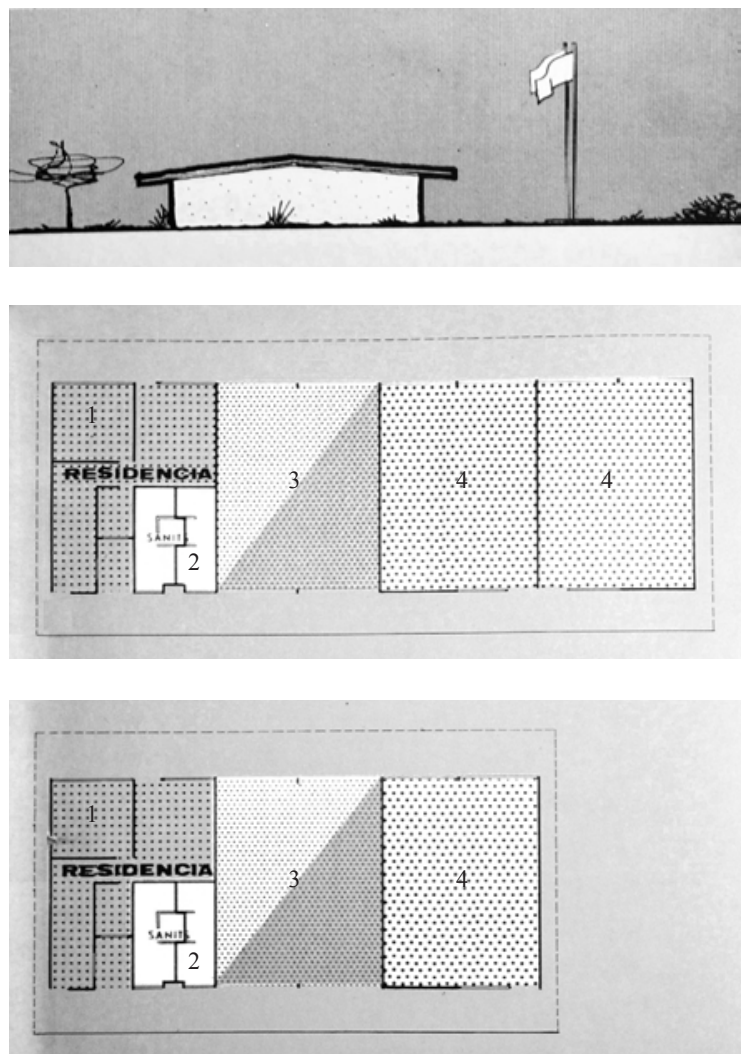

IMAGEM 78. Esquema Escola Rural, Projeto № 943, Fonte: Arquitetura Escolar - FECE, Tema 3 


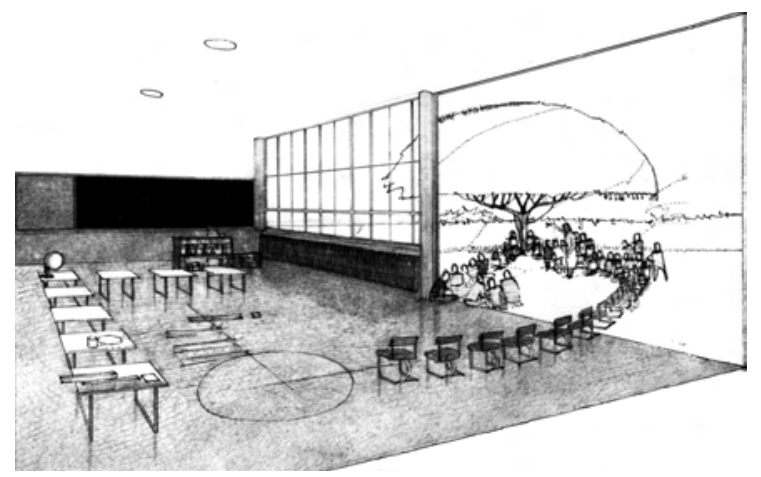

IMAGEM 79. Escola Rural, Richard Neutra em Porto Rico, Fonte: NEUTRA, Richard. »Arquitetura social para países de clima quente«
"A antiga escola rural era assim: $1^{\circ}, 2^{\circ}, 3^{\circ}$ ano juntos em uma sala só. Quando a gente foi lá para conhecer, os pequenos sentaram na frente e os mais altos atrás. Daí a gente pensou: Porque não vamos pôr três lousas nas três paredes da sala. O professor, era um só, dava aula em uma lousa e depois ele ia para a outra, dando assim três aula paralelas. Era um projeto muito simples, mas muito simpático e melhorou muito a situação de ensino nas escolas rurais. Isso era uma coisa muito positiva. [...] A gente estudava cada escola em cada município, tinha tudo um controle. Elaboramos um plano da rede escolar, que definiu os critérios e as prioridades. ${ }^{18}$

O tema da escola rural nos países trópicos, também foi analisado pelo arquiteto Norte Americano Richard Neutra, que visitou Brasil pela primeira vez em 1945. Ele mostrava-se interessado em entender os problemas da adequação das arquiteturas aos diferentes climas. Em 1948 Richard Neutra publicou no Brasil o livro »Arquitetura social em países quente«. $\bigcirc$ livro

18 Entrevista, Clementina Delfina de Ambrosis, 26.05.2014 desdobrou um grande interesse por parte dos arquitetos brasileiros. $\mathrm{O}$ livro foi utilizado recorrentemente pelos arquitetos modernos brasileiros como referência na construção de projetos e edifícios públicos, principalmente aqueles da rede de ensino. Richard Neutra foi contratado, juntamente com profissionais porto-riquenhos, para criar uma nova arquitetura para a ilha de Porto Rico, ou seja, uma arquitetura moderna adaptada aos materiais, técnicas, e clima local. Porto Rico, associado aos Estado Unidos, apresentava uma grande demanda de escolas rurais. É provável que os arquitetos do FECE tenham reconhecido os estudos do Richard Neutra e seus projetos de escolas em Porto Rico. Para poder atender com mais agilidade as demandas das escolas no Estado de São Paulo o FECE começava a desenvolver projetos padrões como a Escola Rural N943. O projeto possuía em suas dependências residência para professores, essas novas unidades escolares permitiram a fixação do professor no local de trabalho, concorrendo assim para que suas atividade no setor de ensino estendam-se, a toda a comu- 
nidade envolvida pela escola. A principal caraterística da Escola Rural foi a sua mobilidade uma vez que, de acordo com sua conceituação arquitetônica, ela pode ser deslocada de um local para outro, sem que com isso afetasse a sua construção. Este projeto apresentou três opções de execução, ou seja, construído em alvenaria auto portante apoiada em sapatas corridas, com forro de peroba, ou tipo »macho e fêmea« paulistinha, com tesouras sustentando cobertura em telha de barro ou tipo fibrocimento; ou também em estrutura de painéis de madeira com transição dos esforços no solo através de pequenas sapatas impermeabilizadas, com as mesmas caraterísticas de forro e teIhado; e a terceira opção foi em »aço cortem«, possibilitando também uma futura remoção.

\section{OS PROJETOS PADRÕES}

O FECE procurou desenvolver e adotar outros projetos padrões e reestruturou a Divisão de Projeto, racionalizando e distribuindo o trabaIho em setores:
Pavimento Térreo

da $1^{\circ}$ a $4^{\circ}$ série - da $5^{\circ}$ a $8^{\circ}$ serie

Pavimento Superior

da $1^{\circ}$ a $4^{\circ}$ série - da $5^{\circ}$ a $8^{\circ}$ serie

1. Recreação

2. Sala de aula

3. Ambientes de pesquisa

4. Corpo Docente / Publico - Serviço

5. Corpo Discente

6. Depósitos e Serventes

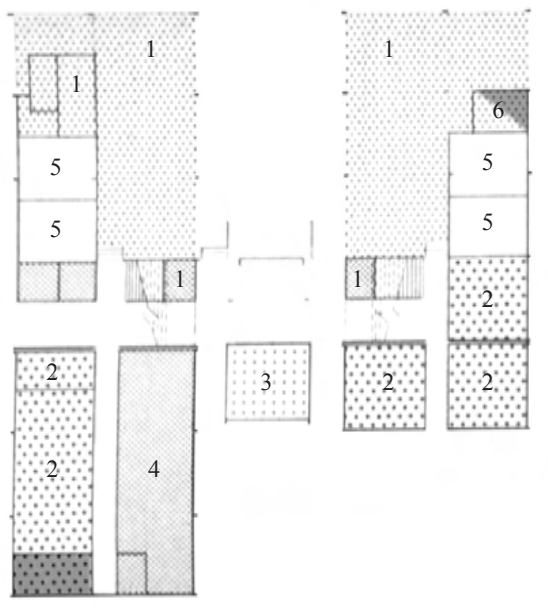

1. Salas de aula

2. Corpo Docente / Publico - Serviços

3. Corpo Discente

4. Ambiente de Pesquisa
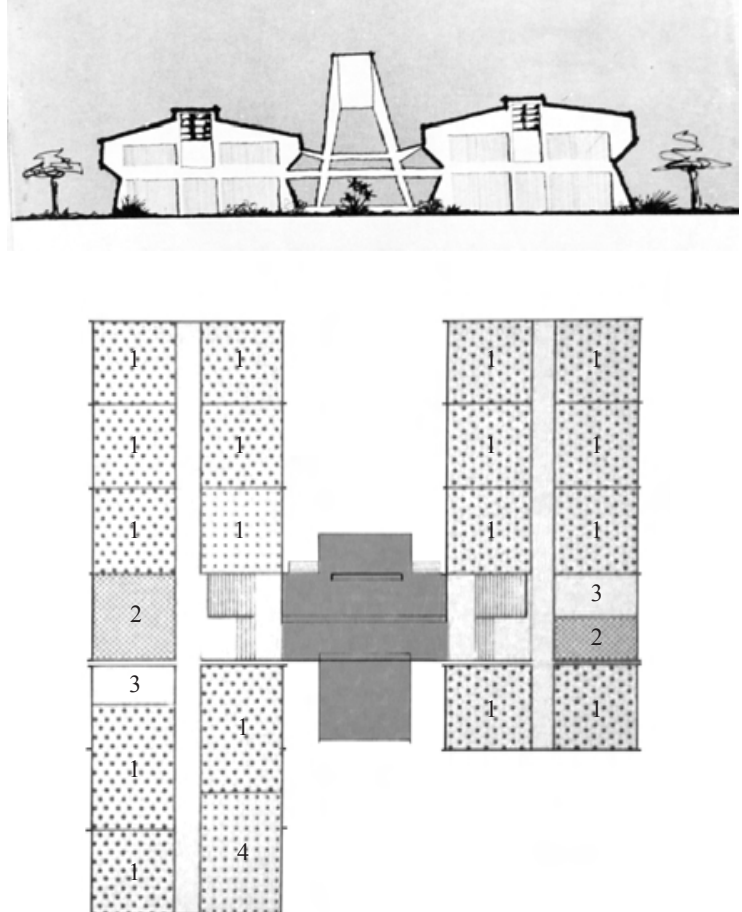

IMAGEM 80. Esquema, Projeto FECE No 856, Fonte: Arquitetura Escolar - FECE, Tema 3 


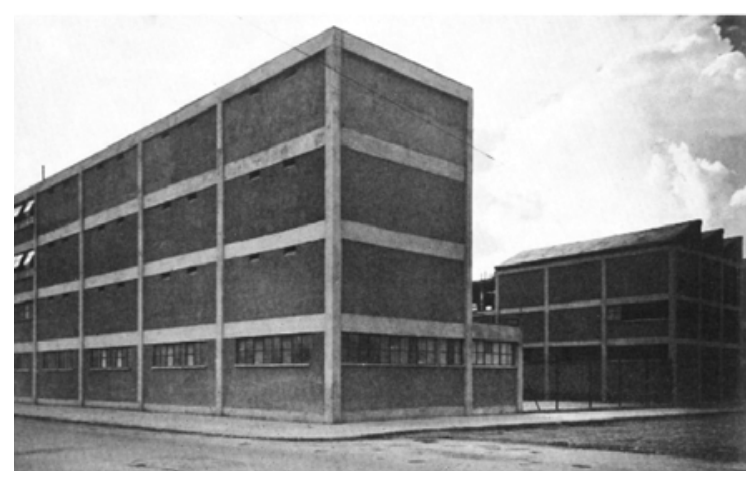

IMAGEM 81. Escuela Vocacional de Tresguerras, 1932, México, Arquiteto Juan O'Gorman, Fonte: Tese de Doutorado, Alexandro Bosquet Navarro a. Setor de Elaboração de Projetos Padrões

b. Setor de Locações

c. Setor de Análise

d. Setor de Reformas e Ampliações

Foco principal foi o desenvolvimento de projetos padrões onde se elaborou projetos completos, visando uma padronização, única resposta possível para enfrentar as situações existentes. $\mathrm{O}$ Setor de Locações funcionou paralelamente, sendo especializado na locação dos referidos projetos.

Um projeto padrão que foi concebido para ser construido em partes ou num todo foi o projeto FECE N 856 (unidade completa de $1^{\circ} \mathrm{Grau}$ ). Este projeto, quando foi construido em partes, abrangeu um bloco das primeiras quatro séries, em sua parte inicial atende ao programa de seis salas de aulas: construindo-se mais dois módulos tem-se o programa de oito salas de aulas, e demais dependências necessárias para um estabelecimento escolar. E finalmente o bloco complementar das quatro últimas séries com os ambientes especiais e demais salas de administração, compondo assim a unidade de ensino integrada. Ponto de partida foi neste projeto o módulo de $60 \mathrm{~m}^{2}$ correspondendo com o tamanho de uma sala de aula. A parti desse módulo desenvolveram-se todas as ou tras dependências, como administração, sanitários, salas especiais etc.. Assim unindo-se determinado número de módulos, compõem-se os blocos, e unindo-se ambos, por meio de uma circulação coberta, onde se encontram a biblioteca, o palco e a caixa d'água. $\mathrm{Na}$ segunda categoria de projeto padrão o FECE desenvolveu o Projeto FECE N 906 térreo, que poderia ser construido em duas ou mais etapas. Na terceira categoria teve os projetos FECE N540, 620, 621, 582 e 769

Ainda como Diretor de Projeto, Sílvio Breno recebeu uma bolsa para estudar as escolas pré-fabricadas no México, segundo ele, na época escolas muito mais desenvolvidas do que no Brasil. No México, o ministro da Educação Narciso Bassols (1931/34) solicitou a Juan O’Gorman a realização de 53 escolas para 30 

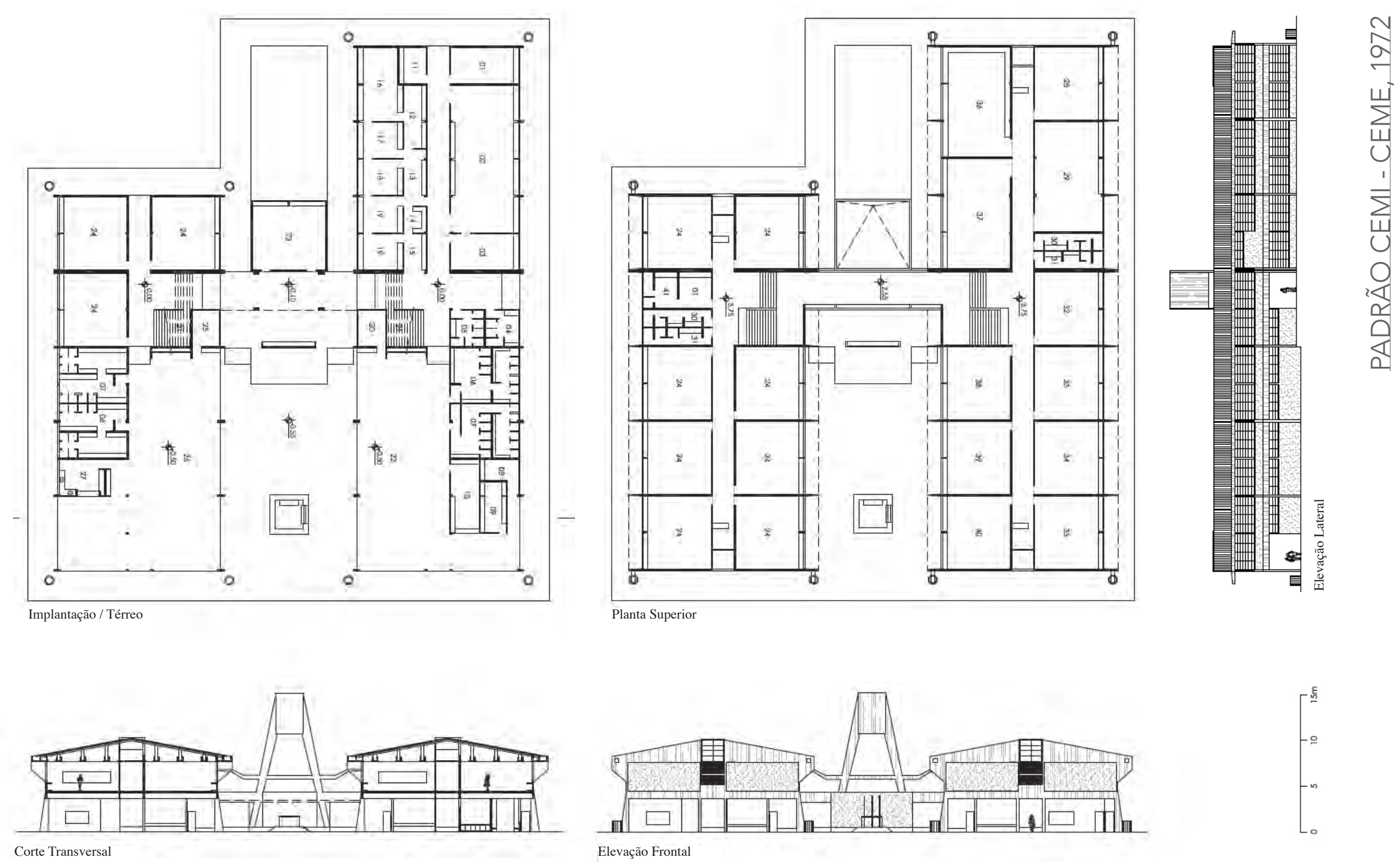
mil crianças excluídas do sistema educacional na Cidade do México. Entre os projetos, a Escuela Vocacional de Tresguerras (1932 a 1934), que é talvez uma solução mais simples e rústica do Bauhaus de Dessau, mas desenvolvido na base da pré-fabricação. Essas propostas tiveram continuidade no país com outros arquitetos em seguida. Assim, Sílvio Breno trouxe para o Brasil as ideias e programações das escolas visitadas. Quando Sílvio Breno chegava da viagem, Mayumi Watanabe ${ }^{19}$, arquiteta, formada na Fauusp em 1960, organizava todo material levantado e começava a estudar e planejar os novos Centros Educacionais do FECE. Hoje conhecido como os três tipos CEMI, CEME, CEMA (MI - Área mínima, ME - Área media, MA - Área máxima). 0 CEMI e o CEME foram concebidos como uns dos padrões mais versáteis, pois a partir de uma série de combinações criaram escolas para várias capacidades e níveis de atendimento. Esses projetos eram o que se traduz de forma mais

19 BUITONI, Cássia Schroeder, Tese de Mestrado, Mayumi Watanabe Souza Lima: a construção do espaço, FAU USP, São Paulo, 2009. clara o fato do edifício ser projetado como um jogo de armar que pode ser montado e desmontado. As versões CEMI - CEME são as mais completas, CEMI - Centro Educacional de Área Mínima ou CEME - Centro Educacional de Área Média. ${ }^{20}$ Em seus 120 anos de história, a arquitetura escolar pública paulista sempre adotou projetos padrões, elaborados para serem implantados em vários lotes diferentes, como também projetos para terrenos específicos.

\section{EQUIPAMENTOS E LABORATÓRIOS}

Durante a presidência de Domingos Facchini (1964 a 1965), Geraldo Vespaziano Puntoni começava a desenvolver, estudos sobre mobiliários escolares em função do desempenho para englobar a indústria. A pesquisa dos mobiliários visava a uma especificação mais precisa dos produtos. A discussão dos equipamentos escolares abrangia questões da qualidade do

20 MELLO, Mirela Geiger de, Tese de Mestrado, Arquitetura Escolar Pública Paulista Fundo Estadual de Construções Escolares - FECE 1966 $-1976$ 
desenho, da ergônomia, da escolha do material e sua resistência, o peso do produto que influenciava a mobilidade do produto no uso, mas entre outros critérios, também a produção do produto em relação com a indústria, a distribuição igualada nas escolas, e a sua manutenção. O objetivo não foi chegar em um produto específico industrializado, e sim, atender produtos com seu desempenho. De que maneira se comporta tal produto, e como ele é avaliado em termos de qualidade, eficiência e rendimento. Dentro dessa oficina de desempenho surgiu também a possibilidade de equipar escolas públicas com laboratórios de física e química.

"Havia um recurso para equipar os laboratórios das escolas. Eu fiquei encarregado para preparar o material da licitação. Assim, a gente conseguiu licitar pela primeira vez um laboratório (escolar)."

Até então, era comum que o professor explicava ensaios científicos atrás de uma vitrine. $\bigcirc$ próprio aluno não podia tocar em nada, ficava para o aluno a observação do procedimento. Através dos recursos, o arquiteto Geraldo Vespaziano Puntoni conseguiu entrar em contato com o Instituto Brasileiro de Estudo e Ciência - IBEC. Não teve nenhuma experiência parecida no FECE para uma licitação de laboratórios escolares. Em parceria com o IBEC o arquiteto desenvolveu um memorial descritivo e elencava e dimensionava todos os equipamentos necessários. Segundo Geraldo Vespaziano Puntoni, um microscópio produzido no Brasil custava muito mais do que um microscópio com o mesmo desempenho no Japão. Na época, simplesmente não havia mercado para esse tipo de produto no Brasil. $\mathrm{O}$ arquiteto conseguiu realizar a concorrência e diversas escolas públicas foram equipadas com laboratórios.

\section{CONSIDERAÇÕES}

Constata-se então que a experiência adquirida com a gestão e todo o processo desde a etapa de planejamento, de projeto e de obras bem como a vivência dos problemas relativos 
à equipamentos, permitiram acumular conhecimento técnico, prático, e pedagógico que se refletiu num processo contínuo de crítica e aperfeiçoamento do modo de pensar e de produzir edifícios escolares. Em suma, ao focalizar os órgãos criados e as construções escolares já construídas, podemos constatar um olhar meIhor, não apenas na compreensão da história da educação e das linguagens arquitetônicas, mas também na história da política pública, social e cultural do Brasil. Um país que ficou marcado pela grande efervescência cultural, política e econômica na década de 1950 e o início dos anos 1960 até ser interrompido pelo governo militar a partir de 1964 a 1985. A meta permanece a mesma durante toda essa trajetória: suprir vagas no ensino público para uma demanda sempre crescente. Cabe-nos recoIher as experiências do passado recente e dos avanços de nosso conhecimento atual para reafirmar um futuro de esperança que, indistintamente, desejamos para as próximas gerações. 

allins

[Recorte 1973 - 1979]
EMURB - Empresa Municipal de Urbanização

[Recorte 1970 - 1973]

(1) KAM

[Recorte 1967- 1970]

[Recorte 1963-1967]

FECE - Fundo Estadual de Construçōes Escolares

[Recorte 1961 - 1990]

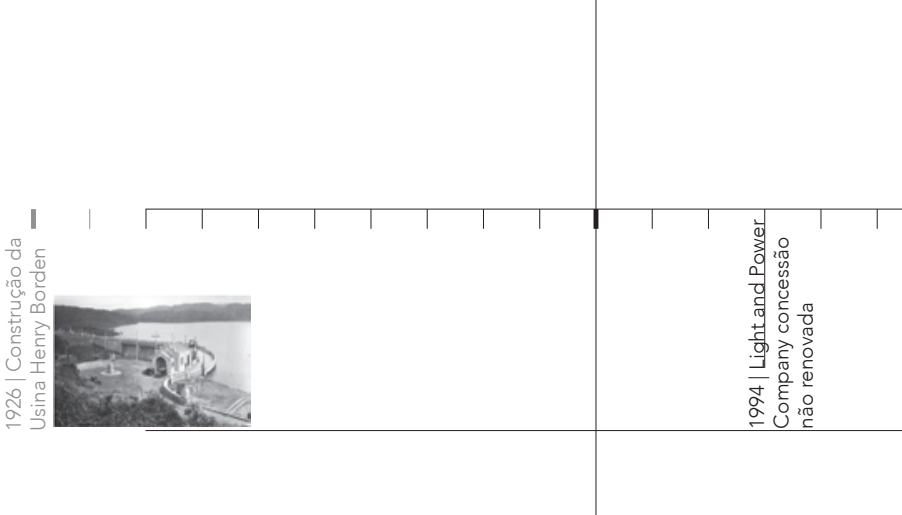

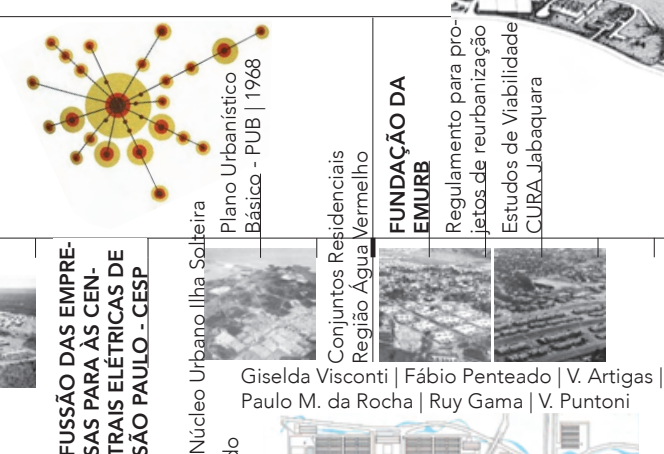

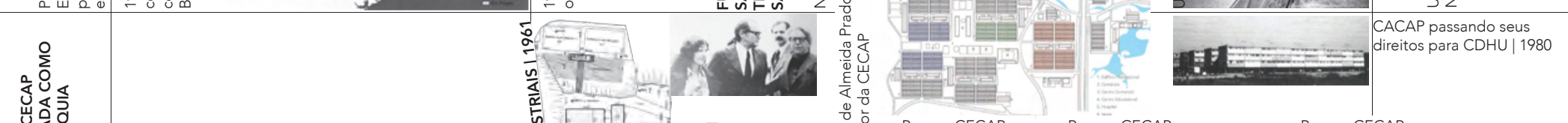
是

ars de Öbras Públicas

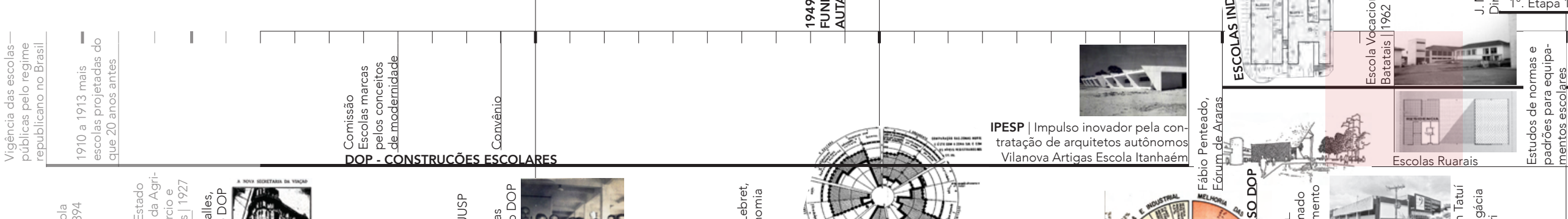
8 \&

$$
\text { rast }
$$

B.

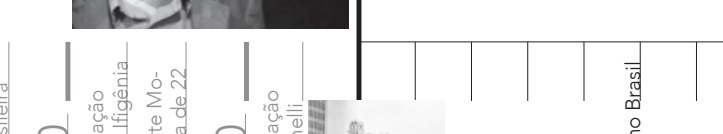
HISTORIA | MUNDO | BRASIL

\section{A} 군

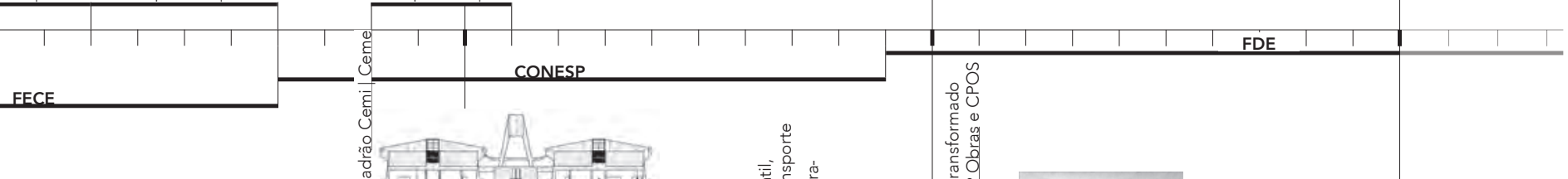
대료 5 F $=$ 



\section{CAPÍTULO 02 - FUNDO ESTADUAL DE CONSTRUÇÕES ESCOLARES}

\section{LISTA DE PROJETOS}

Estudos de Normas e padrões para modificações dos equipamentos escolares, estudos dos programas arquitetônicos dos edifícios escolares da rede oficial do Estado.

Escola Industrial Dr. Júlio de Mesquita da Secretaria da Educação do Estado de São Paulo

Escola Industrial, Secretaria da Educação do Estado de São Paulo

Ginásio Vocacional »Dr. Cândido Portiniari«, Secretaria da Educação do Estado de São Paulo

Escola Industrial, Secretaria da Educação do Estado de São Paulo

Escola Industrial, Secretaria da Educação do Estado São Paulo

Edifício da Escola Industrial Dr. Antenor Soares Gandra, Secretaria Educação do Estado SP
Grupo de Planejamento do FECE

1964-1965

São Paulo, Santo André, SP

1962

São Paulo, Guarulhos, SP

1962

São Paulo, Batatais, SP

1961

Projeto de Reforma

São Paulo, Araçatuba, SP

1961

São Paulo, São Caetano, SP

1961

São Paulo, Jundiaí, SP

1961

Projeto de Reforma 



\section{CAPÍTULO 02 - FUNDO ESTADUAL DE CONSTRUÇÕES ESCOLARES}

\section{BIBLIOGRAFIA}

Obras de referência do arquiteto Geraldo Vespaziano Puntoni: Acervo particular do arquiteto

BUITONI, Cássia Schroeder. Mayumi Watanabe Souza Lima: A Construção do Espaço para a Educação. São Paulo: FAU USP, 2009, (dissertação de mestrado).

FDE, Arquitetura Escolar Paulista, estruturas pré-fabricadas, 2006

FDE, Arquitetura Escolar Paulista, Anos 1950 e 1960

FECE, Fundo Estadual de Construções Escolares, Relatório da Situação da Rede Física Escolar Estadual do Estado de São Paulo. São Paulo, 1972.

Projetos de Arquitetura Escolar, s/d. Execução do Programa de Constru-
FERRATA, Carlos Augusto. Escolas públicas em São Paulo (1960-1972). São Paulo: FAU USP, 2008, (dissertação de mestrado).

HADLICH, Flávio. As escolas do IPESP: projetos de edifícios escolares produzidos para o Instituto de Previdência do Estado de São Paulo de 1959 a 1962. São Paulo: FAU USP, 2009, (dissertação de mestrado).

MELLO, Mirela Geiger de. Arquitetura Escolar Pública Paulista, Fundo Estadual de Construções Escolares - FECE (1966-1976). São Paulo: FAU USP, 2012, (dissertação de mestrado).

PAGE- Relatórios do Plano de Ação;

PINTO, Carvalho, Plano de Ação do Governo, São Paulo: Imprensa Oficial, 1959

ções Escolares, São Paulo: 1963. 


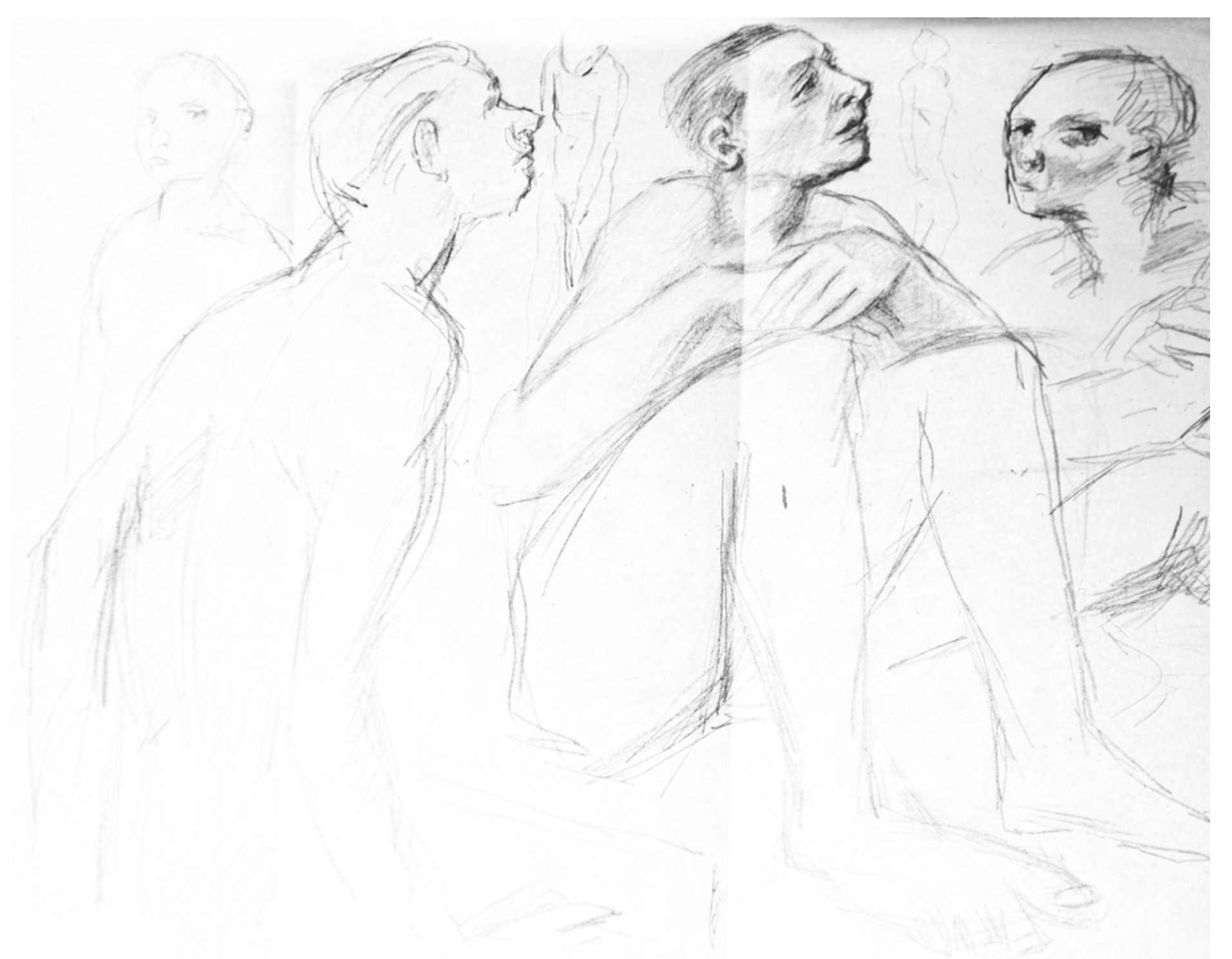




\section{[O ARQUITETO \& O DESEJO]}

CAPÍTULO 3 | RECORTE 1967 - 1969
Entre os anos de 1967 e 1969, o arquiteto Geraldo Vespaziano Puntoni foi cedido pelo DOP para integrar o grupo de trabalho da CECAP, no projeto do Conjunto Habitacional Zezinho Magalhães. A equipe foi coordenada pelos arquitetos João Batista Vilanova Artigas e Fábio Penteado e composta pelos arquitetos Paulo Mendes da Rocha, Arnaldo Martino, Giselda Cardoso Visconti, Renato Nunes e Ruy Gama. O objetivo deste capítulo é analisar a postura dos arquitetos em relação as novas possibilidades arquitetônicas proporcionadas pela pré-fabricação, especificar o quanto essa nova condição construtiva transformou a linguagem arquitetônica e investigar que influência teve no trabalho do arquiteto Gerlado Vespaziano Puntoni, principalmente nos aspectos construtivos e no canteiro de obras, nas interferências sociais e posturas políticas. Deve-se levar em consideração que a maioria da obra foi desenvolvida de forma convencional e que a abordagem através dos seis órgãos públicos é essencial para a compreensão da formação do arquiteto em foco.

»O objetivo foi, através das novas possibilidades dadas pela pré-fabricação, atingir um nível de excelência que demonstrasse que a qualidade de uma habitação não deveria corresponder ao padrão econômico de uma determinada classe social, mas aos conhecimentos técnicos do seu momento histórico, que permitissem uma construção racionalizada, honesta e acessivel a todos. $\|^{1}$

\section{A HISTÓRIA DA CAIXA ESTADUAL DE CASAS PARA O POVO - CECAP}

CECAP foi uma autarquia criada em 1949 pelo Governo do Adhemar de Barros, com objetivo de desenvolver programas de política habitacio-

1 ARTIGAS, Rosa Camargo. Paulo Mendes da Rocha, V.1, Cosac Naify, São Paulo, 2002, Depoimento Paulo Mendes da Rocha, p. 184
IMAGEM 82. Desenho Geraldo Vespaziano Puntoni, 1962, Fonte: Arquivo do Sílvio Breno de Souza Santos. 


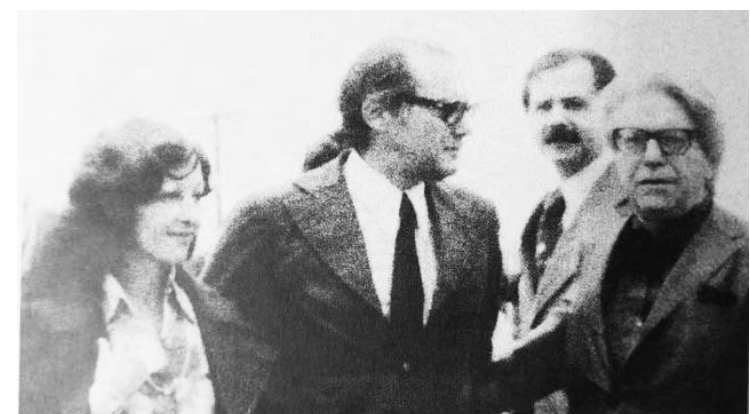

IMAGEM 83. A partir da esquerda: Maria Giselda Visconti, Fabio Penteado e Vilanova Artigas. Inauguração do Parque CECAP, Guarulhos, 1972. Fonte: Fabio Penteado: ensaios de arquitetura.

120 nal no Estado de São Paulo. A CECAP era um órgão da administração pública, que possuía uma certa autonomia financeira. Seu objetivo era construir e vender casas para os trabalhadores sindicalizados. Os critérios estabelecidos para a habilitação das moradias eram: Renda salarial baixa; Quantidade de filhos menor de idade; e o tempo de sindicalização na Grande São Paulo. Em 1966, José Magalhães de Almeida Prado (Zezinho Magalhães) assumiu a superintendência da CECAP e convidou o arquiteto Ruy Gama para ser seu assessor. Este teve influência na decisão de chamar os arquitetos Vilanova Artigas e Fábio Penteado, que posteriormente chamariam Paulo Mendes da Rocha, para coordenarem juntos o projeto do Conjunto Habitacional Zezinho Magalhães Prado em Guarulhos, chamado Parque CECAP. O conjunto foi construído em três grandes etapas, a primeira de 1968 a 1972, a segunda de 1972 a 1976 e a terceira de 1978 a 1981. A cada nova licitação eram efetuadas inovações ou correções, dessa forma os projetos acabaram sofrendo reformulações contínuas. Em 1975, a CECAP teve seu nome al- terado para Companhia Estadual de Casas Populares. Pouco tempo depois, em 1980, acabou sendo desativada e teve seus direitos passados para a Companhia do Desenvolvimento Habitacional e Urbano (CDHU), onde foram armazenados os dados remanescentes daquela época.

\section{CONTRATAÇÃO E RESPONSABILIDADE}

»Chegaram no DOP e perguntaram quem queria trabalhar no CECAP? Daí, eu falei: eu quero! Estou disposto. Eles perguntaram se não havia mais alguém. Eu disse: tem essa moça.... $\mathbb{1}^{2}$

»Essa moça« citada a cima, era Maria Giselda Visconti, e já no dia seguinte os dois estavam participando da equipe na elaboração de um conjunto habitacional de 10.000 unidades. Ruy Gama, assessor do Zezinho Magalhães, foi que apareceu no DOP para convidar Maria Gisel-

2 Entrevista, Geraldo Vespaziano Puntoni e Maria Giselda Visconti, 14.07.2016 
da Visconti e Geraldo Vespaziano Puntoni para fazerem parte da equipe da CECAP. Todos os arquitetos se conheciam da Universidade, ou pela proximidade que tinham com os órgãos públicos, como o DOP. Mas o lugar ideológico, frequentado por todos, foi na época o IAB (Instituto de Arquitetos do Brasil).

»Havia na época um convívio muito grande dos arquitetos em torno do IAB. Final de tarde sempre passávamos no IAB, era o nosso órgão ideológico. A gente ficava lá discutindo. [...] Assim, todos os arquitetos se conheciam. Mas quem nos levou para o CECAP foi o Ruy Gama. $\ll^{3}$

Toda contratação aconteceu em circunstâncias delicadas, pois naquele momento, em plena ditadura militar, Vilanova Artigas já era conhecido como uma personalidade política de esquerda. Ele ainda não havia sido cassado como professor da FAU USP, isso aconteceria somente em 1969, mas ele já estava sendo visado pelo aparelho repressivo do estado, por ser um militante do Partido Comunista.
"Quem realmente maquinou toda essa trama foi o Ruy Gama [...]. Ele convenceu Zezinho Magalhães a contratar Vilanova Artigas. Porque? Porque, o Ruy era do Partido Comunista assim como o Artigas. $\ll^{3}$

Mesmo que Ruy Gama tenha convencido Zezinho Magalhães a contratar Vilanova Artigas, isso ainda não explicava como eles contrataram um arquiteto que era alvo de perseguição por parte da Ditadura Militar. Segundo a tese de Geraldo Vespaziano Puntoni:

\section{» [...] Eles (Ruy Gama/Zezinho Magalhães)}

contrataram o Fábio Penteado, e ele terceirizou Vilanova Artigas e Paulo Mendes da Rocha. Fábio Penteado foi o cara que respondeu pelo contrato. Provavelmente o DOPS e a polícia secreta tinham consciência disso. Mas isso o Fábio Penteado contornou, ele foi político. $\ll^{3}$

Fábio Penteado foi responsável principalmen-

3 Entrevista, Geraldo Vespaziano Puntoni, 15.12.2015 
te pela administração política do empreendimento, que exigia intermediação de vários setores envolvidos, fossem eles públicos ou privados. Isso não quis dizer, que o arquiteto não participou do projeto; segundo Geraldo Vespaziano Puntoni, Fábio Penteado participou, discutiu e trabalhou muito em seu desenvolvimento. Maria Giselda Visconti desenhou o hospital, Renato Nunes projetou o estádio,

e Geraldo Vespaziano Puntoni fez os centros educacionais, principalmente por causa de sua experiência no FECE (Fundo Estadual de Construções Escolares). Arnaldo Martino foi responsável pelo planejamento e dimensionamento dos componentes da pré-fabricação nos conjuntos habitacionais. $\bigcirc$ gerenciamento geral da obra ficou nas mãos do engenheiro Falcão Bauer e do arquiteto Alfredo Paesani.

»Para coordenar os projetos de implantação do conjunto foi chamado o arquiteto Stipan Milicic, antigo parceiro de Fábio ${ }^{4}$

4 PENTEADO, Fábio. Ensaios de arquitetura, São Paulo, 1998, p.141.
Stipan Milicic tinha como bagagem sua experiência com a implantação da nova capital da lugoslávia, Zagreb, construída no pós guerra.

\section{O CONJUNTO}

A idéia inicial do conjunto foi fazer moradias agrupadas em 6 setores denominados freguesias, sendo que cada setor teria um raio de 150 metros, um centro educacional e um pequeno comércio para uso cotidiano. É possível perceber que a configuração escolhida foi inspirada pela ideia moderna de unidade de vizinhança. Cada lamina possui três andares sobre pilo tis, e o bloco é formado por dois edifícios in terligados por um jardim sombreado, onde se localizam as escadas de acesso, cada uma servindo 12 apartamentos. Segundo Maria Giselda Visconti, o pergolado não foi construído: 

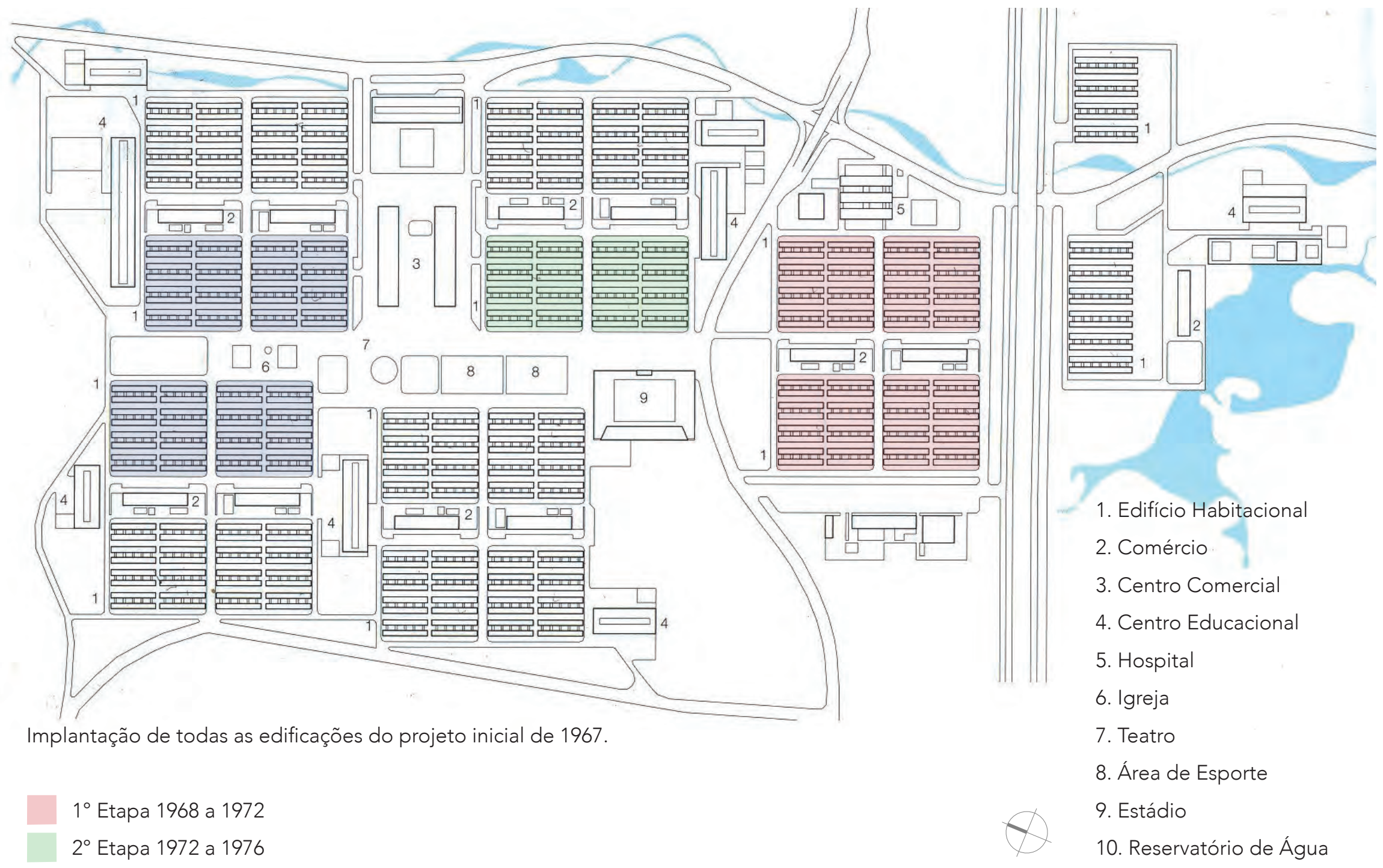

$1^{\circ}$ Etapa 1968 a 1972

$2^{\circ}$ Etapa 1972 a 1976

$3^{\circ}$ Etapa 1978 a 1981 

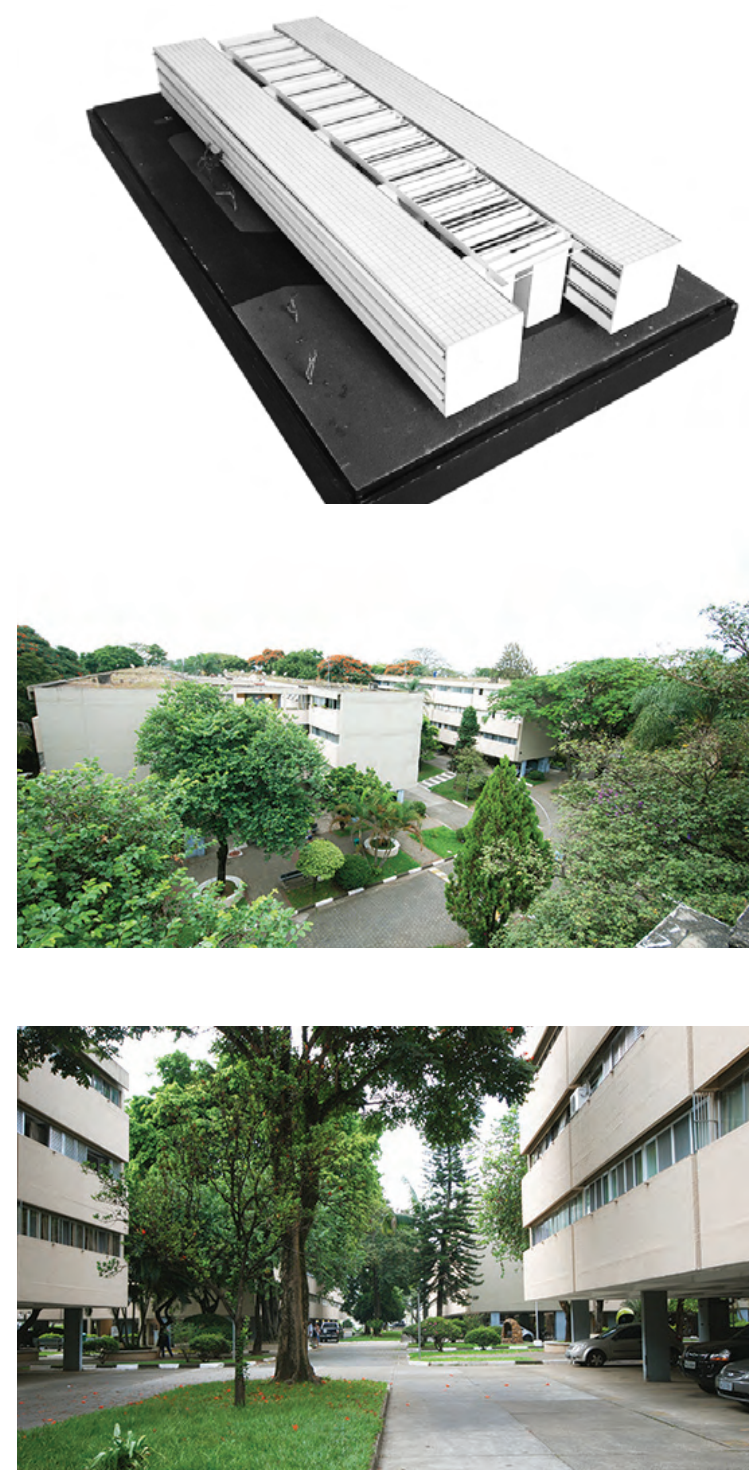

124
»Porque ficava muito caro. Não tínhamos dinheiro parafazer. Mesmo assim ele fez parte do projeto e tinha uma intenção e com estudos de luz e sombra. ${ }^{5}$

Além dos estudos de luz e sombra, o pergolado unificava as duas lâminas, e criando um conjunto com um jardim, que interligaria os dois blocos. Além disso, a área da freguesia foi toda interligada pelos espaços verdes, que penetram de forma sutil nos próprios edifícios e acabam estabelecendo uma relação global através de um eixo central, onde se localizam os principais equipamentos de uso comum. Essa faixa verde articula o centro principal do núcleo, onde foi planejado um estádio e dois blocos de comércio com lojas, hotéis, cinema e restaurante.

5 Entrevista, Maria Giselda Visconti, 14.07.2016

IMAGEM 87. Maquete, Unidade Habitacional, Parque CECAP, com pergolado, Fonte: Sebastian F. Beck, Maquete Escola da Cidade

IMAGEM 85 Parque CECAP, Fotografia da cobertura do prédio, Fonte: Sebastian F. Beck, 15.02.2016

IMAGEM 86.Parque CECAP, Fotografia da área verde entre dois blocos, Fonte: Sebastian F. Beck, 15.02.2016 apartamento, de $64 \mathrm{~m}^{2}$, possui uma planta de uso flexível, a fim de permitir aos moradores diversas possibilidades de adaptação de acordo com seus hábitos ou número de pessoas na família. A proposta-tipo conta com três dormitórios: sala, banheiro, cozinha e lavandaria. $\bigcirc$ equipamento hidráulico está concentrado em uma área do bloco e é composto por cozinha, banheiro e lavanderia. Como o apartamento ao lado é espelhado, ele acaba aproveitando a mesma área para tais instalações.

A planta das unidades é racionalizada de forma a economizar o máximo de espaço possível para a circulação. As paredes internas tem 9 centímetros e também foram planejadas para ocupar o mínimo de espaço possível. Os armários embutidos ao longo das duas fachadas, também possibilitam um maior espaço interno. O objetivo principal da obra foi a redução de custo, o que acabou afetando pontos diferentes, como a redução de consumo de concreto, redução nos condutos d'água (entrada direta da água da rua, sem caixas d'água nos blocos), aparta- 


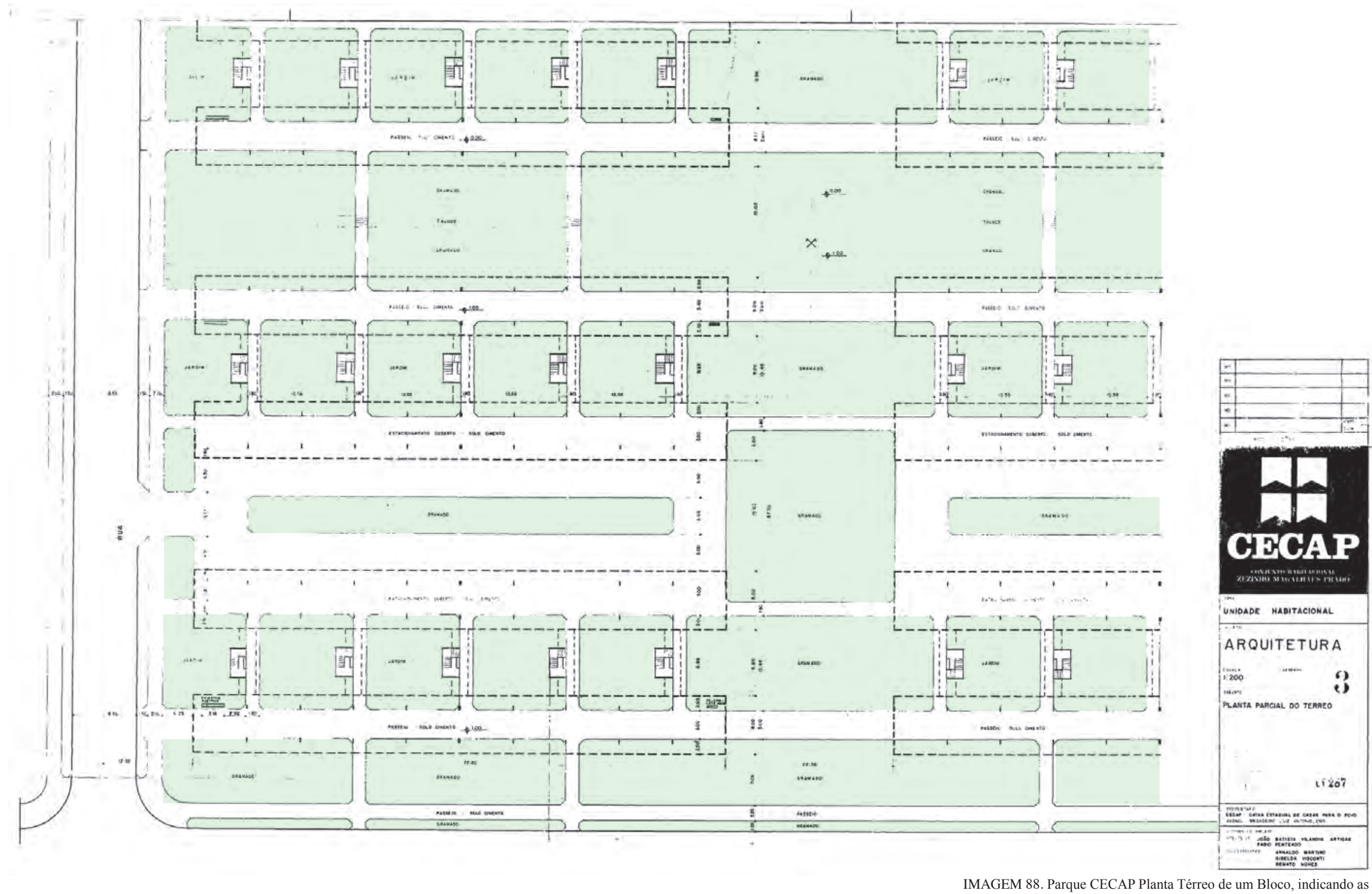

IMAGEM 88. Parque CECAP Planta Térreo de um Bloco, indicando as áreas verdes, Fonte: Acervo Biblioteca FAU USP 

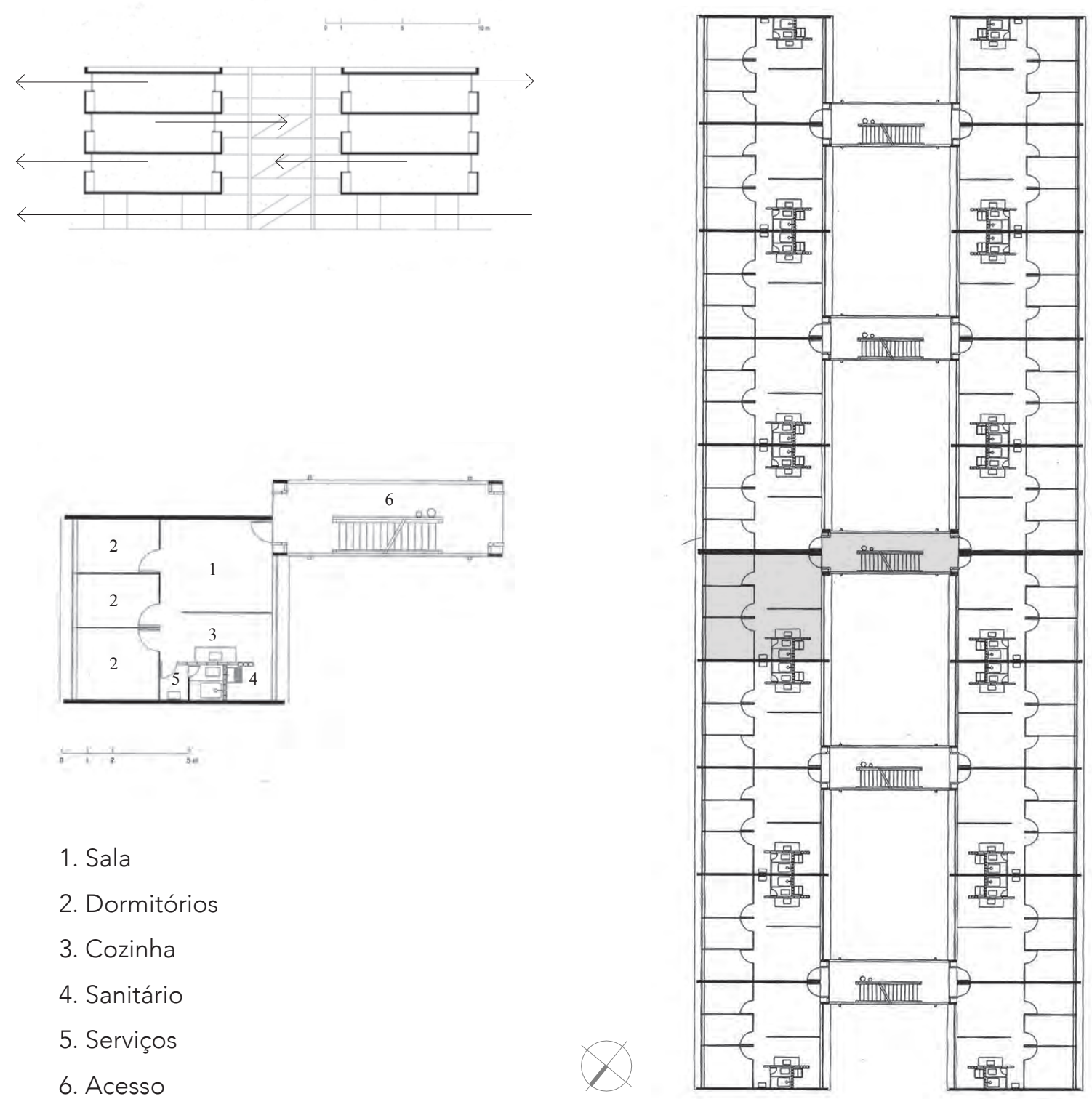

Projetos 1957 - 1999, Cosacnaify, 2006

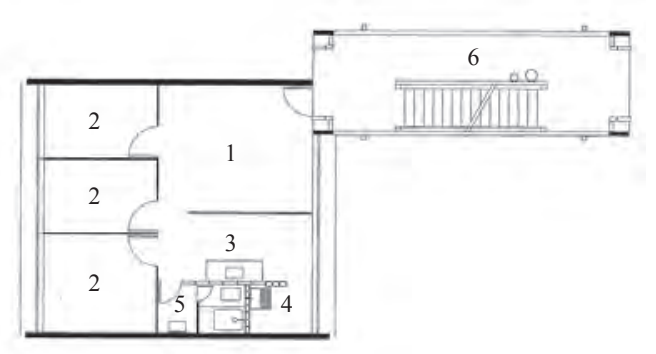

IMAGEM 89. Parque CECAP, Pavimento Tipo, Paulo Mendes da Rocha,

1. Sala

2. Dormitórios

3. Cozinha

4. Sanitário

5. Serviços

6. Acesso 
mentos sem contra piso e uma grande quantidade de caixilhos da mesma especificação.

\section{OS EQUIPAMENTOS}

Para a diminuição do custo final da obra, foram propostos equipamentos domésticos. Assim houve o desenvolvimento de dois protótipos, um fogão e uma geladeira. Infelizmente nenhum deles foi construído.
»Havia a intenção de colocar equipamentos domésticos em todos os apartamentos. O pai do Fábio Penteado tinha uma companhia de equipamentos domésticos (Hoje a DAKO). [...] Alguém contratou a mulher do Paesani, Eugênia Paesani, para fazer um estudo sobre esses equipamentos, mas a conclusão da pesquisa deixou claro que as pessoas que compraram um apartamento no CECAP já tinham todo o equipamento necessário, então resolveram cancelar o planejamento desses equipamentos domésticos. ${ }^{6}$
Assim, a incorporação dos equipamentos na obra acabou ficando no mundo dos »desejos«. A pesquisa de Eugênica Paesani comprovou que o mercado já oferece o que as pessoas com o perfil dos futuros moradores do prédio em geral possuem e compram.
6 Entrevista, Geraldo Vespaziano Puntoni, 15.12.2015
IMAGEM 92. Equipamentos Domésticos, Fábio Penteado, Ensaios de arquitetura, São Paulo, 1998, p.142.
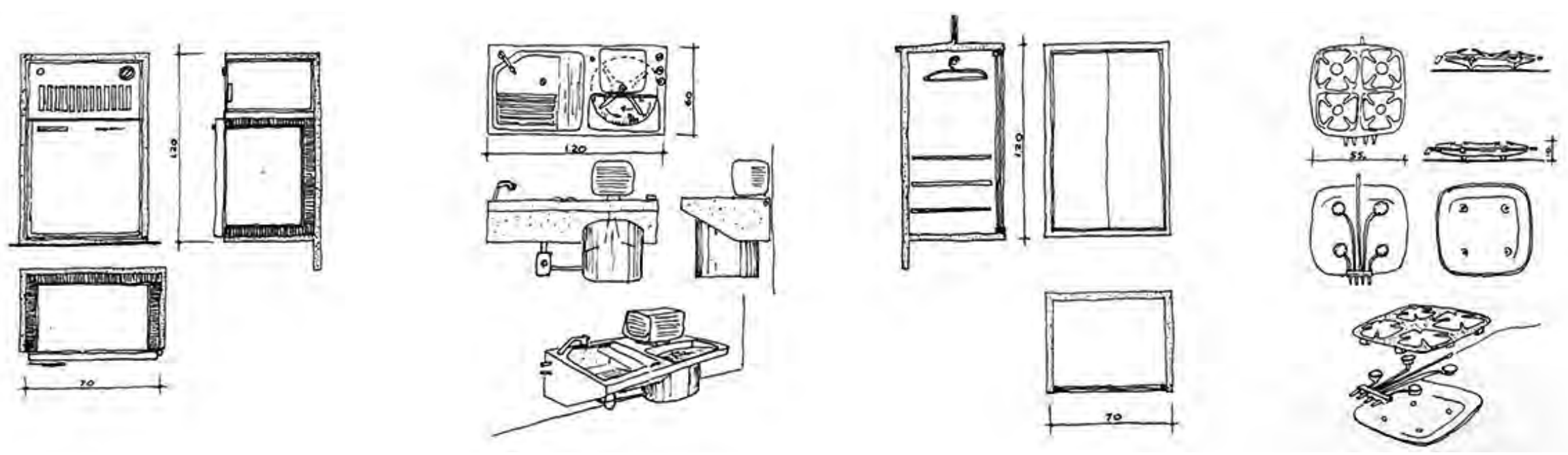

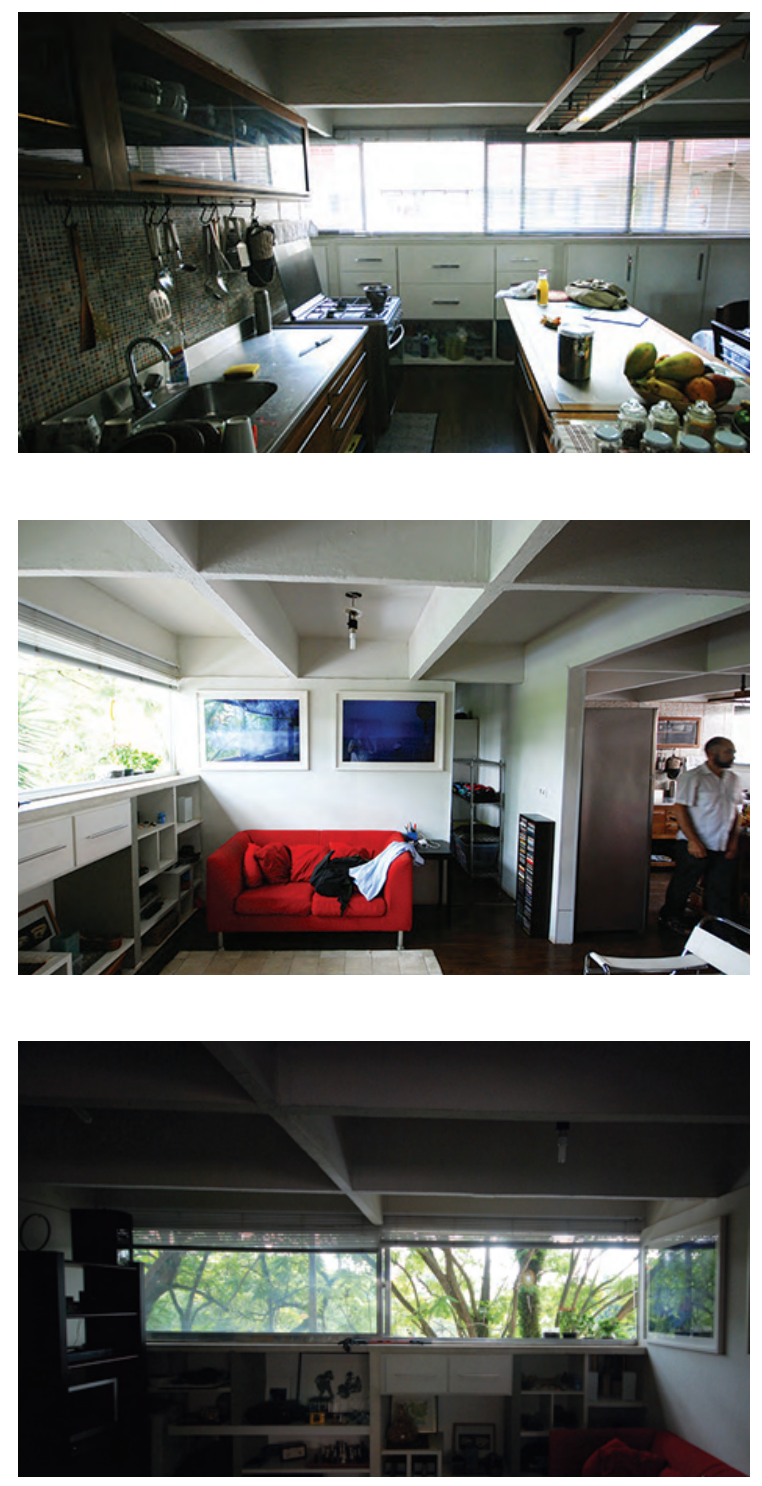

128

\section{A PRÉ-FABRICAÇÃO OU A QUALIDADE DA ECONOMIA}

O projeto foi pensado para ser executado utilizando a técnica de concreto armado, com uma perspectiva de aproximação da pré-fabricação e da pré-moldagem.

»Fábio Penteado tentou convencer a construtora Camargo Corrêa a fazer a obra de pré-fabricada. Tudo foi desenhado e desenvolvido pelo Arnaldo Martino. O projeto tinha todas as condições para ser inovadora. «?

A pergunta é: Por que diante das inovações propostas, o »desejo« pela pré-fabricação não caminhava no sentido da industrialização da construção?

IMAGEM 94. Parque CECAP, Fotografia Cozinha, Fonte: Sebastian F. Beck, 15.02.2016

IMAGEM 93. Parque CECAP, Fotografia Sala, Fonte: Sebastian F. Beck, 15.02.2016

IMAGEM 95.Parque CECAP, Fotografia pela janela da sala, Fonte: Sebastian F. Beck, 15.02.2016
»O CECAP não foi feito em pré-fabricação porque a pré-fabricação reduz a mão de obra necessária durante a obra. No Brasil, a mão de obra não é nada industrializada. Se vocêfaz uma pesquisa na indústria do material de construção, vai descobrir que ela é responsável por 7\% do produto bruto nacional e não tem nada a ver com a construção brasileira. Infelizmente a construção brasileira compra seu material na indústria do material de construção. Esses $7 \%$ são resultado de compras em mutirão, como o cara que pinta a sua casa, a pessoa que compra um saco de cimento, etc.. [...] Não existem materiais de construção produzidos em função da indústria da construção. Se você vai num depósito de materiais de construção, você compra pregos, areia, cimento ou tijolos - mas você não compra uma estrutura pronta. O que vale é a quantidade de pessoas trabalhando na obra e a construtora não quer repartir isso com a indústria. Quando uma obra começa a ser industrializada, ou seja, ficar mais eficiente, a construtora acaba ganhando menos, por isso a Camargo Corrêa não topou. $\ll^{7}$

$\overline{7}$ Entrevista, Geraldo Vespaziano Puntoni, 15.12.2015 
A garantia da lucratividade ganhou contra um sistema inovador. $O$ conservadorismo e suas soluções aparentemente imutáveis, cujo resultado vem sendo sempre lucrativo, venceu do risco econômico. Na construção civil brasileira, o sistema construtivo é caraterizado por um processo tradicional arcaico, que incorpora os mecanismos sociais, como a falta de qualificação de mão de obra, as relações de trabalho e a remuneração baixa. Tal sistema é conservador e muito arraigado nos resultados que se mostram lucrativos e com pouco risco econômico. Entretanto o projeto, ou o desejo, da industrialização da construção, contribuiu para as possibilidades do desenvolvimento industrial no país. Principalmente o papel dos arquitetos, que propuseram a pré-fabricação, no próprio canteiro ou fora, foi transformado, pois novas "portas«, que tiveram como consequência a substituição da habilidade do artesão pelo uso da máquina. Dessa foram seria possível a racionalização do processo construtivo com objetivo de otimizar o uso dos recursos materiais, humanos, energéticos e financeiros. A proposta dessa equipe de arquitetos destaca-se até hoje, pois o esforço em tornar crível a industrialização da construção, tem como intuito os benefícios que podem ser gerados ao povo brasileiro; tanto em termos econômicos, qualidade de moradia, e uma produção maior de habitações, quanto uma melhoria do serviço no canteiro de obra. Para o arquiteto Geraldo Vespaziano Puntoni, a experiência no projeto »Parque CECAP« foi fortemente inspiradora, no sentido de como o arquiteto pode auxiliar o país a trilhar um rumo em direção a industrialização da construção, desenvolver o seu campo específico de conhecimento e fazer da arquitetura um instrumento indutor da racionalização construtiva, articulando projeto e obra.

\section{OS CENTROS EDUCACIONAIS}

Os Centros Educacionais, seis no total, possuem a mesma planta, mas com diferentes implantações junto as Freguesias, atendendo às exigências da política de ensino do Estado. Vale lembrar, que o arquiteto Geraldo Vespaziano Puntoni chegou a atuar na equipe do projeto

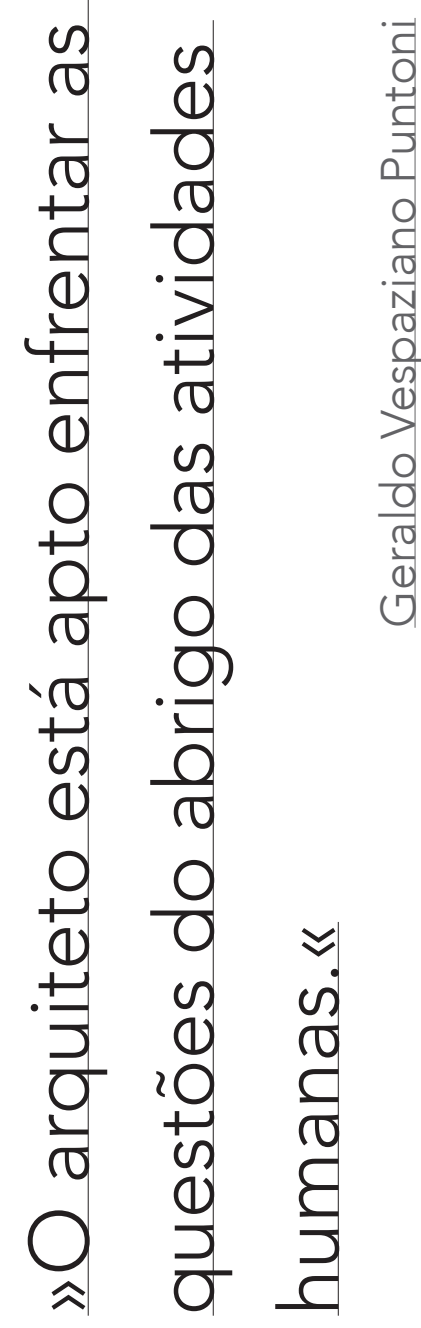



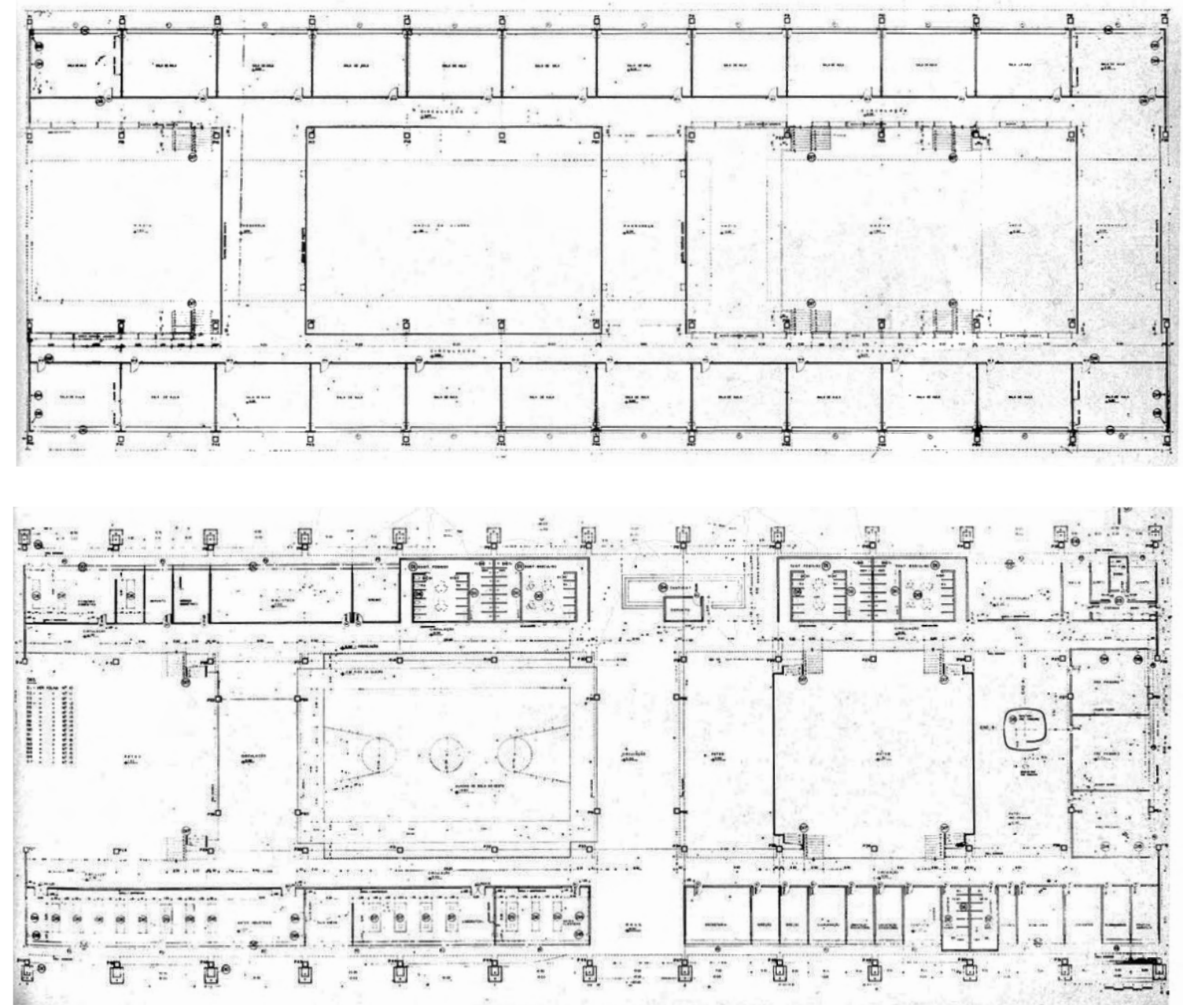

IMAGEM 96. Centro Educacional, Pavimento Superior, Fonte: Acropole, abril 1970, $\mathrm{N}^{\circ} 372$

IMAGEM 97. Centro Educacional, Pavimento Térreo, Fonte: Acropole, abril 1970, $\mathrm{N}^{\circ} 372$
»Parque CECAP« através da sua atuação profissional no FECE, onde adquiriu experiências com construções escolares. A sua experiência com o desenvolvimento dos centros educacionais foi principalmente coordenada e orientada pelo arquiteto Vilanova Artigas. Segundo Geraldo Vespaziano Puntoni:

"As escolas planejadas não tinham nada de pré-fabricado. A ideia do pré-fabricado foi levado adiante somente nos prédios habitacionais. $\ll^{8}$

O edifício é formado por um volume único retangular organizado por uma malha regular cujo módulo é a largura da sala de aula. Possui um total de doze módulos no sentido longitudinal e três módulos no sentido transversal. A planta é organizada através de três faixas longitudinais, que definem o zoneamento funcional. No pavimento térreo, as duas faixas nas extremidades contam com administração, laboratórios, oficinas e sanitários. Na faixa central estão dois pá-

8 Entrevista, Geraldo Vespaziano Puntoni, 15.12.2015 
tios cobertos elevados em meio nível, e entre os dois pátios está localizado o ginásio, meio nível abaixo. No andar superior, as duas faixas laterais, equivalem a uma linha de módulos, onde estão localizadas as salas de aula. Os pátios e a quadra estão abertos e permitem relações visuais através das pontes e corredores do pavimento superior. A estrutura da edificação segue o rigor da modulação estabelecida e das faixas organizadoras referentes ao programa funcional. $\bigcirc$ módulo rege a distância entre os pilares no sentido longitudinal, evidenciando o programa. No sentido transversal, os módulos nas extremidades se encontram a mesma distância enquanto as colunas na faixa central tem quase o dobro dessa distância, gerando assim quatro linhas de pilares. A cobertura é uma laje em concreto do tipo caixão perdido. A partir da faixa central, a grelha nervurada recebe subtrações, que configuram zenitais, permitindo a entrada de iluminação natural sobre a quadra e os pátios. Os volumes localizados nas extremidades estão recuados da estrutura, dando espaço para a grande cobertura, tema central
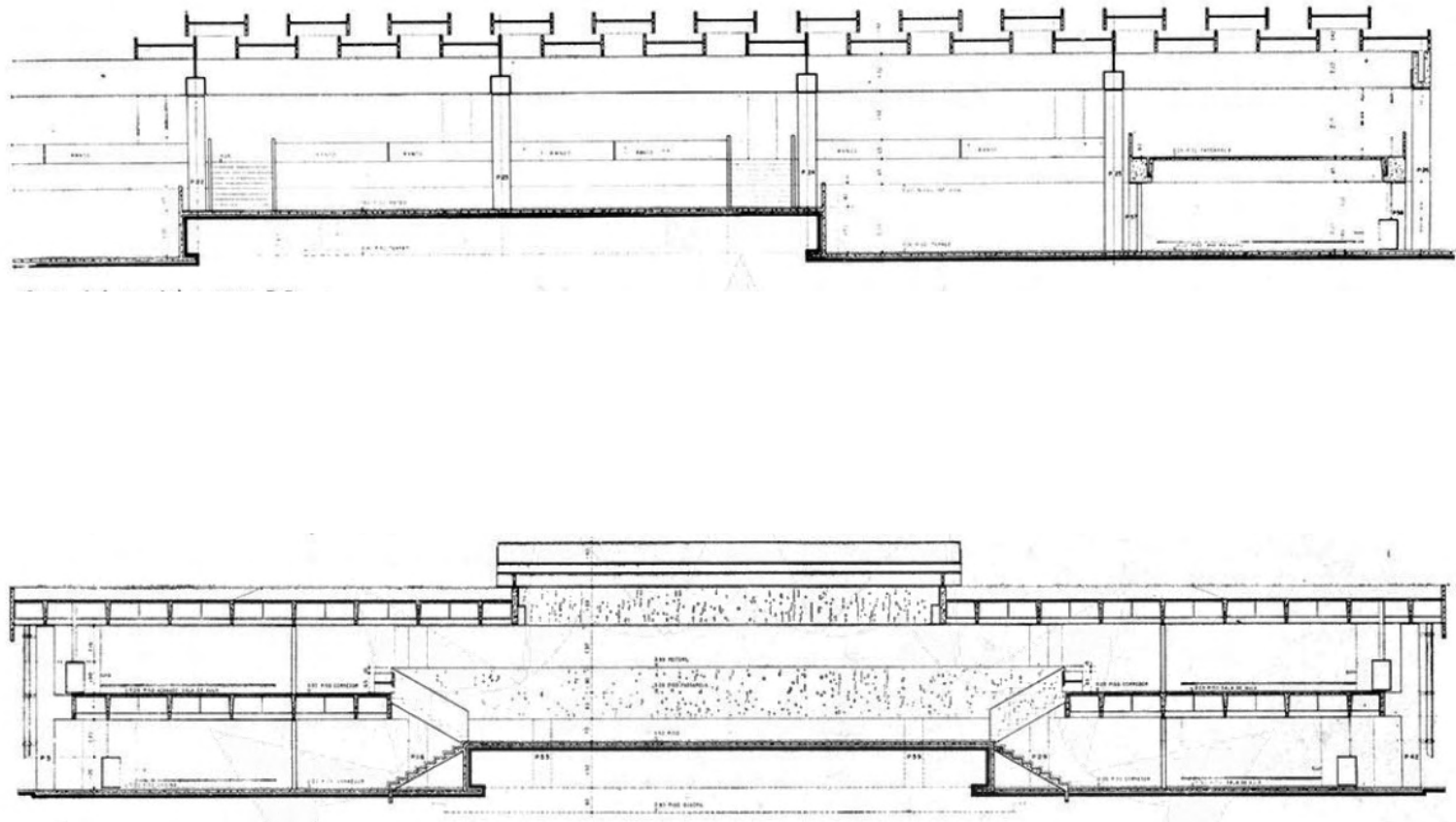

IMAGEM 98. Centro Educacional, Corte A-A parcial, Fonte: Acropole, abril 1970, Nº372

IMAGEM 99. Centro Educacional, Corte B-B, Fonte: Acropole, abril 1970, No372 

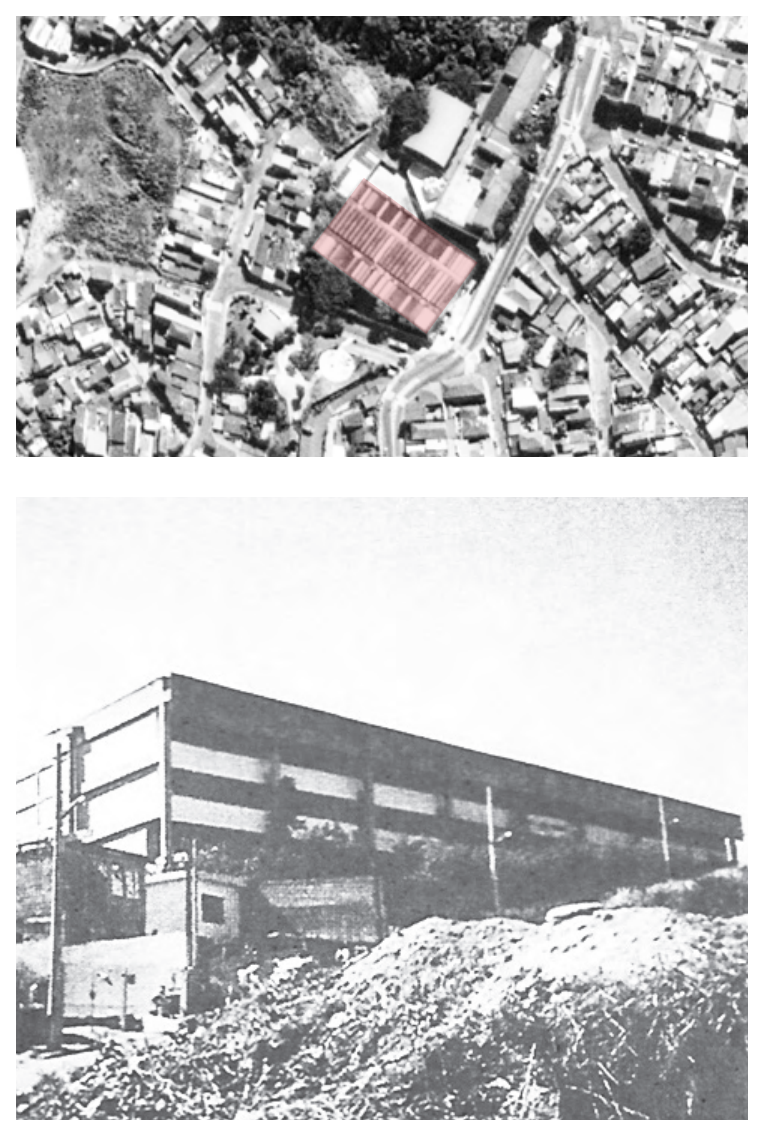

IMAGEM 100. Fotografia da situação, EE João Solimeo, Vila Brasilândia, Fonte: Google Earth, 2015

IMAGEM 101. Fotografia, EE João Solimeo, Vila Brasilândia, Fonte: Acervo do arquiteto Geraldo Vespaziano Puntoni

132 que une todas as funções comunitárias do centro educacional, uma característica marcante da linguagem arquitetônica de Vilanova Artigas. As largas passarelas, que conectam os usos nas faixas laterais e promovem uma generosa circulação no sentido longitudinal fazem referência às rampas e caminhos infinitos do projeto da FAU USP. Os centros educacionais não foram realizados desta forma. Em vez das propostas da equipe do CECAP, foram construídas duas escolas públicas pelo FDE: a EEPSG Francisco Antunes Filho e a EEPSG Vereador Elido de Oliveira Neves.

\section{EE JOÃO SOLIMEO, VILA BRASILÂNDIA, 1969}

Mesmo assim, o projeto do centro educacional influenciou o arquiteto Geraldo Vespaziano Puntoni. Apesar da pesquisa não ter como objetivo uma análise da obra do arquiteto autônomo Geraldo Vespaziano Puntoni, ela permite um olhar mais amplo e com maior nitidez para as repercussões causadas por suas experiências.
Nesse sentido, parece oportuno mencionar a Escola Estadual João Solimeo, em Vila Brasilândia, um projeto construido pelo arquiteto autônomo Geraldo Vespaziano Puntoni em 1969, ou seja, um ano depois da construção do »Parque CECAP«. O projeto insere-se em uma malha urbana existente, o que já o difere do planejamento do conjunto »Parque CECAP«. A escola foi implantada em uma situação topográfica peculiar: Uma encosta, caraterística que pede uma resposta distinta do Centro Educacional da CECAP. A planta da cota $-3.30 \mathrm{~m}$, que abriga toda a área administrativa da escola, está organizada em uma faixa linear, interrompida no sentido transversal pelo eixo de acesso da escola. Uma escada, com um grande patamar, é o elemento central da escola. A escada transmite os desníveis, que seguem através da incorporação da topografia no edifício. Dessa forma foi possível uma implantação eficiente, ou seja, sem grande movimento de terra. A partir da cota $0.00 \mathrm{~m}$, as relações com o centro educacional do »Parque CECAP « ficam mais evidentes. Assim como no CECAP, nas extremidades as duas faixas, que 
comportam sanitários, laboratórios e um refeitório. No andar superior estão as salas de aula, com o mesmo rigor de modulação do »Parque CECAP «. Na faixa central está localizada a quadra esportiva e duas oficinas de artes industriais. Mesmo no sentido longitudinal, os usos se adaptam à topografia do terreno. A quadra esportiva está na cota $-1.65 \mathrm{~m}$ e as oficinas na cota $+1.65 \mathrm{~m}$, ambas abertas, e permitindo relações visuais através dos corredores e da escada central. A estrutura da edificação segue o mesmo rigor que a modulação estabelecida no projeto do CECAP. As faixas organizam o programa funcional. $\bigcirc$ módulo rege a distância entre os pilares no sentido longitudinal como já observado no Centro Educacional CECAP. No sentido transversal, os módulos nas extremidades estão na mesma distância e as colunas na faixa central possuem entre si o dobro da distância. A cobertura é uma laje em concreto, com uma telha ca-

IMAGEM 102.PLANTA NÍVEL -3.30, EE João Solimeo, Vila Brasilândia, 1969, Fonte: Arquivo FDE

IMAGEM 103.PLANTA NÍVEL 0.00, EE João Solimeo, Vila Brasilândia, 1969, Fonte: Arquivo FDE
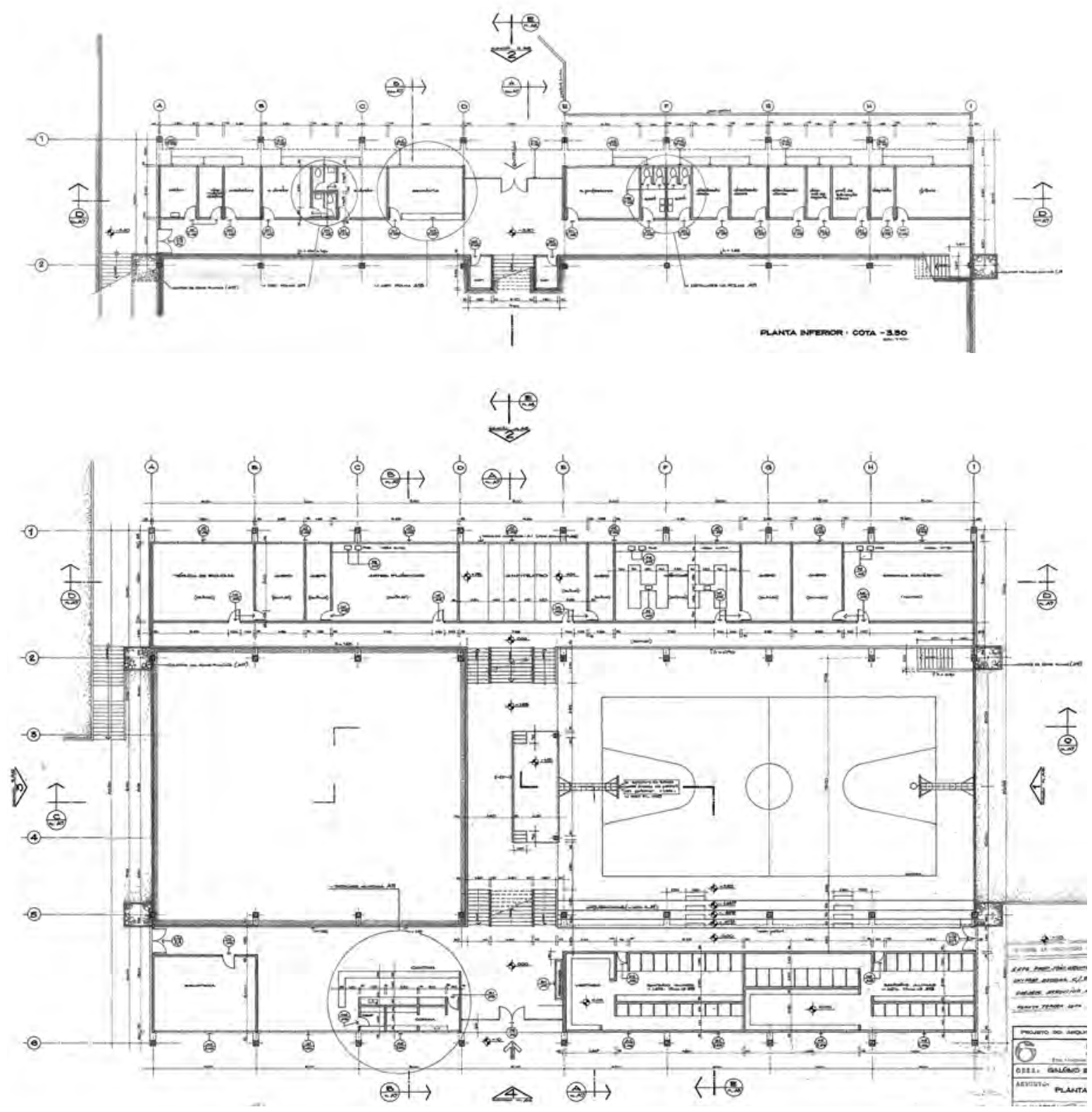
nalete de eternit. Na faixa central, vigas de concreto armado em forma de »Y« vencem o grande vão e permitem a entrada de luz zenital sobre a quadra esportiva e oficinas. $\bigcirc$ discurso sobre a escola de Brasilândia teve como objetivo comprovar a influência e aprendizagem contínua do arquiteto Geraldo Vespaziano Puntoni, através de sua convivência com os arquitetos da equipe do Conjunto Habitacional Zezinho Magalhães.

\section{RESERVATÓRIO DEÁGUA}

O reservatório de água foi concebido como parte do Conjunto Habitacional Zezinho MagaIhães, mas também ficou no mundo das idéias. O desejo de um reservatório único para abastecer todo o conjunto era essencial para os arquitetos, que buscavam por qualidade através da economia. As qualidades do conjunto apa-

IMAGEM 104. PLANTA NÍVEL 3.30, EE João Solimeo, Vila Brasilândia, 1969, Fonte: Arquivo FDE

IMAGEM 105.CORTE LONGITUDINAL, EE João Solimeo, Vila Brasilândia, 1969, Fonte: Arquivo FDE

IMAGEM 106. CORTE TRANSVERSAL, EE João Solimeo, Vila Brasilândia, 1969, Fonte: Arquivo FDE
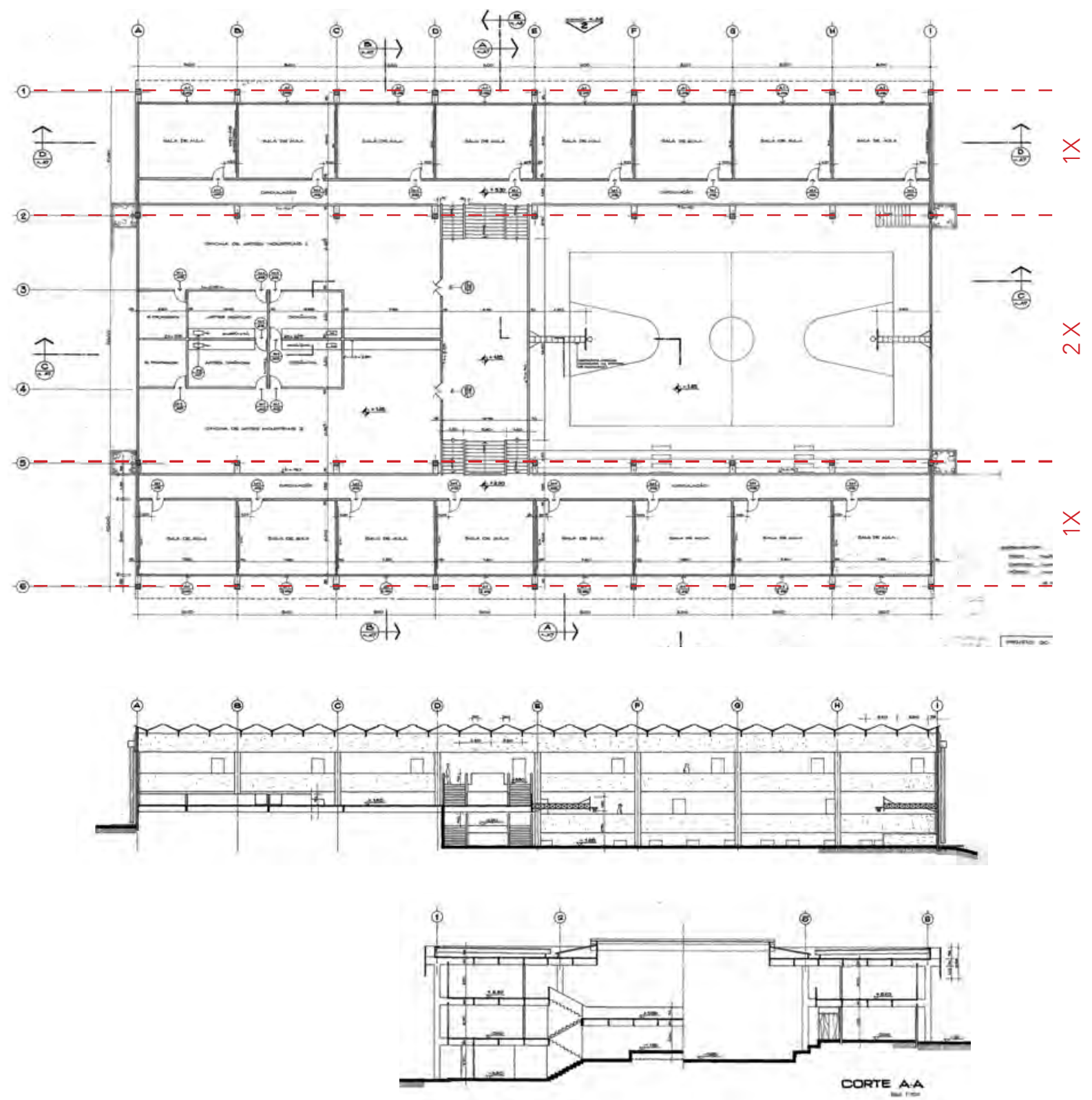
recem, de uma maneira muito bonita e através de soluções simples, como no caso do reservatório. Talvez seja uma das soluções mais triviais, singelas e com condições de trazer uma melhoria imediata para as casas e habitações. Mesmo assim, não foi possível de ser realizado. A inquietação do arquiteto Geraldo Vespaziano Puntoni é perceptível até hoje:

»No final, não fizeram a caixa d'água única cada prédio ficou com a sua própria caixa. A cidade de São Paulo recebe água de duas represas, e cada um de nós tem 2000 mil litros de água guardados em casa. É muito mais caro e muito mais anti-higiênico. E se você quer limpar a caixa d'água você joga fora dois mil litros. Quem tem o direito de guardar dois mil litros de água em casa? «"

A ideia do abastecimento se orientou, mais uma vez, no espírito da racionalização. A rede de distribuição abasteceria diretamente os pontos de consumo, eliminando as caixas d'água elevadas

9 Entrevista, Geraldo Vespaziano Puntoni, 15.12.2015

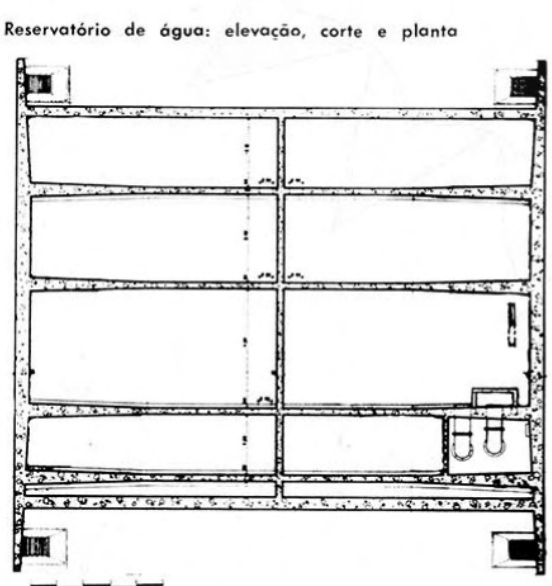
uma redução de até 35\% do custo das tubulações, segundo as informações na publicação do projeto na revista Acrópole, em 1970. Uma outra peculiaridade foi a implantação do reservatório, que acabou ficando na parte alta do terreno e ajudou a constituir uma praça voltada para o lazer. $\bigcirc$ projeto gerou uma grande área sombreada e todo o terreno ao redor foi arborizado. A discussão dos conceitos de abasteci-
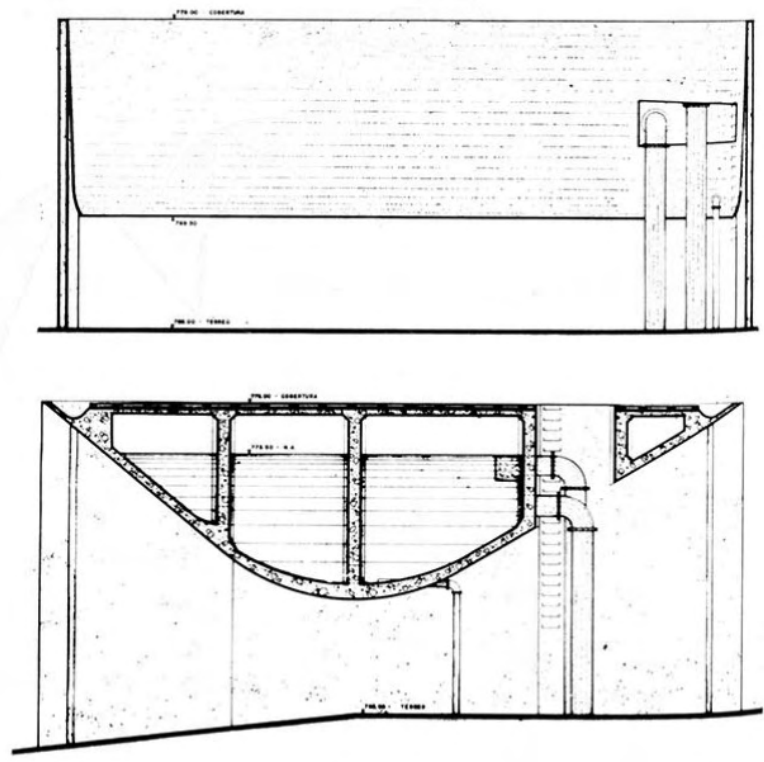

mento, que incluem aspectos mais gerais, como por exemplo água, eletricidade, recolhimento de águas pluviais e tráfego, introduz o capítulo a seguir. A CESP (Centrais Elétricas do Estado de São Paulo) , instituição para a qual o arquiteto Geraldo Vespaziano Puntoni foi transferido, foi responsável por obras de grande dimensão. As razões da transferência do arquiteto para a IMAGEM 107. Reservatório Elevado. Planta, Corte,Elevação. Fonte: Acropole, abril 1970, $\mathrm{N}^{\circ} 372$ 
CESP podem ser interpretadas de diversas maneiras. Segundo ele:

»O desenhista da CECAP ganhava 10 vezes mais do que nós dois (Maria Giselda Visconti e Geraldo Vespaziano Puntoni). Evidentemente como funcionário público você tem garantias, aposentadoria e etc.. Quando o Hélio Penteado (Arquiteto da CESP) ligou para a minha mulher, e falou para ela, que ele tinha arranjado um emprego, no qual eu ganhasse 10 vezes a mais. Eu não tive como negar o convite para a CESP. $«^{10}$

A explicação é simples e óbvia, e as circunstâncias familiares fazem provavelmente parte dessa decisão. Em 1965 nasceu o seu primeiro filho, Álvaro Puntoni. Durante a sua integração na CECAP, ele recebe seu segundo filho, Pedro Puntoni.

IMAGEM 108. Conjunto Habitacional Cecap Guarulhos, São Paulo, 1967, Fonte: http://vilanovaartigas.com/cronologia/projetos/conjunto-habitacional-cecap-guarulhos

10 Entrevista, Maria Giselda Visconti, Geraldo Vespaziano Puntoni, 14.07.2016 

atlitis

[Recorte 1973 - 1979]
EMURB - Empresa Municipal de Urbanização

[Recorte 1970 - 1973]

(1) KANA

[Recorte 1967 - 1970]

CECAP - Caixa Estadual de Casas para o Pove

[Recorte 1963 - 1967]

FECE - Fundo Estadual de Construções Escolares

[Recorte 1961 - 1990]

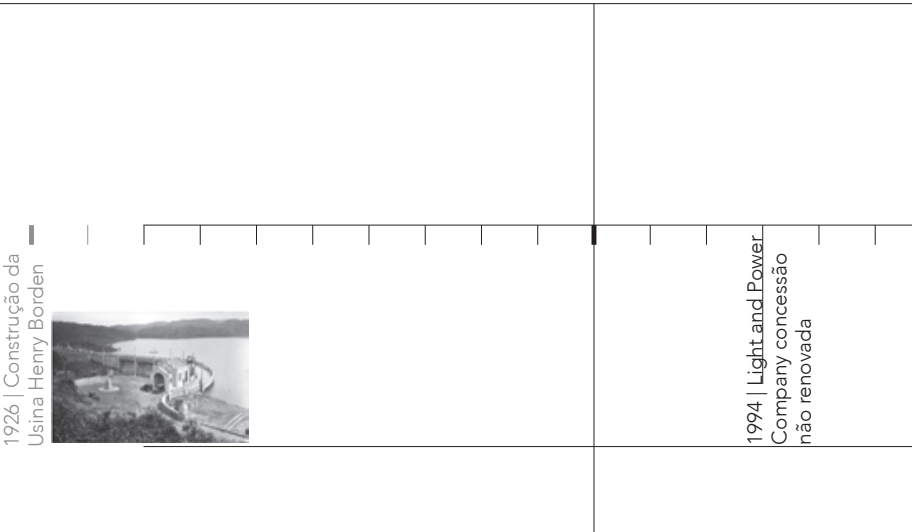

W

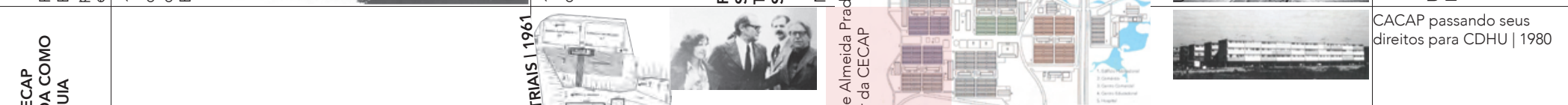

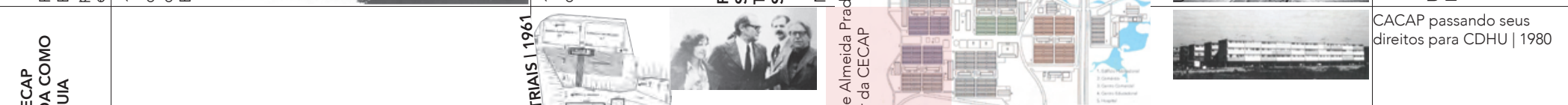

ars

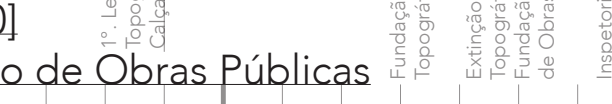

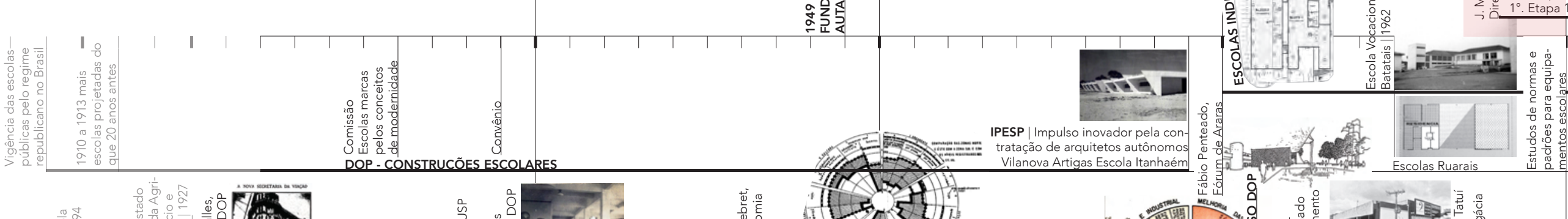

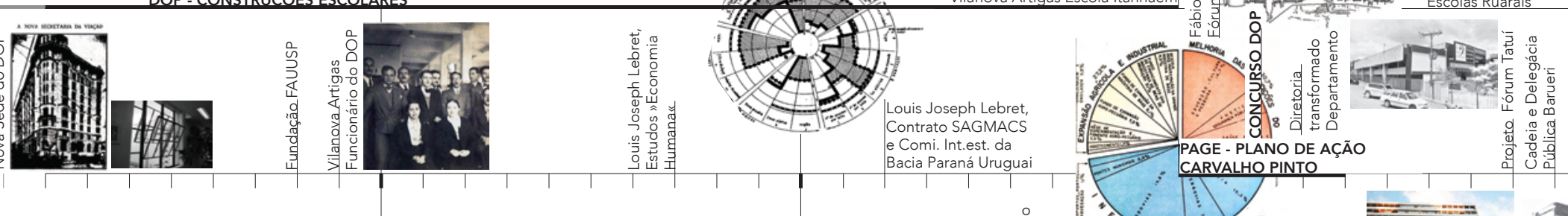



CAPÍTULO 03 - CAIXA ESTADUAL DE CASAS PARA O POVO

\section{LISTA DE PROJETOS}

Integrante do grupo de trabalho coordenado pelo Fábio Penteado, Vilanova Artigas e Paulo Mendes da Rocha

Conjunto Habitacional »Zezinho Magalhães Desenvolvimento das Escolas pro-

$1967-1969$

Prado«, Guarulhos

gramadas no conjunto 



\section{BIBLIOGRAFIA}

Obras de referência do arquiteto Geraldo Vespaziano Puntoni: Acervo particular do arquiteto

AAPAH, Associação amigos do patrimônio e arquivo histórico, http://aapah.org.br

ARANTES, Pedro Fiori. Arquitetura Nova, Sérgio Ferro, Flávio Império e Rodrigo Lefèvre, de Artigas aos mutirões. Editora 34, São Paulo, 2002

ARTIGAS, Rosa Camargo. Paulo Mendes da Rocha, V.1, Cosac Naify, São Paulo, 2002.

ARTIGAS, Vilanova, Instituto Lina Bo e P. M. Bardi, 1997.

ARTIGAS, Vilanova, N54, Gustavo Gili, 2G, 2010

BONDUKI, Nabil. Origens da habitação social no Brasil. São Paulo: 1994. Tese de doutorado apresentada na FAUUSP. São Paulo, Estação Liberdade/FAPESP, 1998

BRUAND, Yves. Arquitetura contemporânea no Brasil. São Paulo, Perspectiva, 1981.

CERÁVOLO, Fabiana, A Pré-Fabricação em Concreto Armado Aplicada a Conjuntos Habitacionais no Brasil: O caso do "Conjunto Habitacional Zezinho Magalhães Prado". São Paulo: Escola de Engenharia de São Carlos, 2007 (dissertação de mestrado)

CUNHA, Gabriel Rodrigues da. Uma análise da produção de Vilanova Artigas entre os anos de 1967 a 1976. São Paulo: Escola de Engenharia de São Carlos, 2007 (dissertação de mestrado)

CONTRAVENTO, Revista №2, Núcleo do grêmio da Faculdade de Arquitetura da USP, São Paulo, 2004
FERRO, Sérgio. O Canteiro e o Desenho, Vicente Wissenbach, 2005

ISAAC, Solimar Mendes. Parque CECAP Guarulhos: Transformação urbana. Universidade de São Paulo, Faculdade de Arquitetura e Urbanismo. São Paulo, 2007 (dissertação de mestrado)

KOURY, Ana Paula. Artigo. Para ler arquitetura e democracia no Brasil: os arquitetos e o debate interrompido com o golpe de 1964. http:// au.pini.com.br/arquitetura-urbanismo/241/artigo310681-3.aspx

PENTEADO, Fabio. Ensaios de Arquitetura. Empresa das Artes, São Paulo, 1998. 


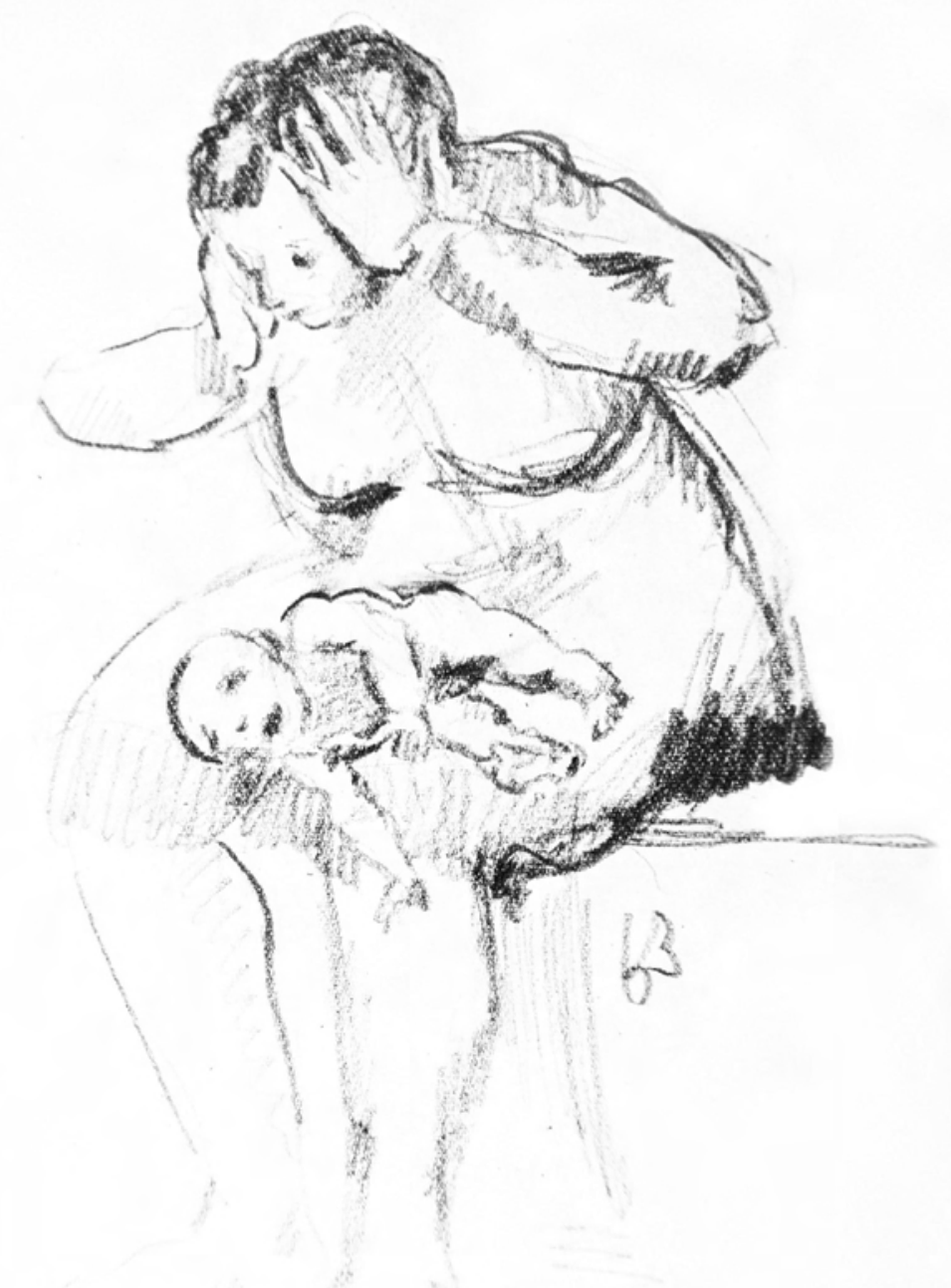


O arquiteto Geraldo Vespaziano Puntoni se afastou do grupo de planejamentos da CECAP antes da primeira fase do conjunto Zezinho Magalhães Prado. Em 1969, ele pediu ao DOP para que fosse transferido para a CESP por motivos financeiros, afinal estava constituindo uma família, e talvez por sabedoria - sabia que o desejo de uma obra industrializada não iria se realizar de forma esperada.

Esse capítulo pretende investigar de qual forma a CESP contribuiu para o desenvolvimento das regiões afastadas do Estado de São Paulo, através da construção de usinas hidrelétricas e de vilas operárias. Pretende-se evidenciar as ações urbanísticas por meio de análise e comparação durante as décadas de 60 e 70. Deseja-se investigar também como a iniciativa estatal, aliada às empresas, indústria e firmas de projeto, conseguiu atingir o objetivo fundamental de desenvolvimento econômico e social do Estado. $\bigcirc$ arqui- teto Geraldo Vespaziano Puntoni é o fio condutor para conduzir pelos arranjos concatenados.

\section{A HISTÓRIA DA CESP}

Um aspecto marcante na história da energia elétrica no Brasil foi o domínio das concessionárias estrangeiras na produção e distribuição energética, principalmente no período pós Segunda Guerra. Na década de 50, 80\% da produção de energia elétrica se encontrava na mão de companhias estrangeiras, que não investiram no setor por conta das baixas tarifas impostas pelo governo. No entanto, houve um ponto onde a crise energética obrigou o governo a programar novos investimentos na expansão da energia elétrica, durante a segunda gestão do governo Getúlio Vagas, que definiu uma presença maior do Estado no gerenciamento de energia elétrica.

IMAGEM 109. Desenho Geraldo Vespaziano Puntoni, 1962, Fonte: Arquivo do Sílvio Breno de Souza Santos. 
»Entre 1945 e 1962 (ano da constituição da Eletrobrás - estatal responsável pela política nacional de energia elétrica), inúmeras companhias públicas de energia elétrica, federais e estaduais, foram criadas. $\|^{1}$

Em 21 de julho de 1966, o Governo do Estado baixou um decreto que estabeleceu uma comissão para propor medidas referentes à unificação das empresas de energia elétrica do Estado, ou seja, um grupo que analisou a conveniência da fusão das seis empresas formalmente privadas com as cinco estaduais. A partir de um parecer favorável da Comissão, a fusão das empresas deu origem, em 5 de dezembro de 1966, às Centrais Elétricas de São Paulo S.A., a CESP (Vianna, 2006)

No início da história da CESP houve uma participação de arquitetos nas primeiras fábricas e usinas, mas essa participação passou desper-

1 SEGAWA, Hugo, arquiteturas no Brasil, 1900 - 1990, Ed USP, 1998, São Paulo, p.164 cebida. A situação mudou com a fundação da Faculdade de Arquitetura e Urbanismo (FAU) da Universidade de São Paulo, em 1948. A procura de técnicas mais adequadas para a expressão arquitetônica em um país subdesenvolvido, que aspirava criar uma indústria autônoma, contava com êxitos expressivos e com uma nova visão urbana. Talvez pela primeira vez no país se conjugava uma iniciativa estatal que aliava universidade, empresas, indústria e firmas de projeto.

»De fato, a experiência da CESP pode ser considerada exemplar: não só técnicas, não só vontade política, mas esse empreendimento contou com pesquisa tecnológica e científica que ancora em um trabalho sedimentado ao longo de pelo menos três gerações. Pela primeira vez, uma larga experiência de iniciativa estatal se conjuga com a universidade, com as empresas, com a indústria, com as firmas de projeto, para se atingir um objetivo fundamental para o desenvolvimento econômico e social do Estado. $\ll^{2}$
2 Arquitetura na CESP, Companhia energética de São Paulo, Nina Maria Jamra Tsukumo, São Paulo, 1994, p. 35 
01. UHE José Ermírio de Moraes - Água Vermelha

02. UHE Ilha Solteira

03. UHE e eclusa Três Irmãos

04. UHE e eclusa Engenheiro Souza Dias - Jupiá

05. UHE e eclusa Nova Avanhandava

06. UHE e eclusa Mário Lopes Leão - Promissão

07. UHE e eclusa Ibitinga

08. UHE e eclusa Álvaro de Souza Lima - Bariri

09. UHE e eclusa Barra Bonita

10. UHE Corumbataí

11. UHE e eclusa Porto Primavera

12. UHE Rosana

13. UHE Taquaruçu

14. UHE Capivara

15. UHE Canoas I

16. UHE Canoas II

17. UHE Lucas Nogueira Garcez -Salto Grande

18. UHE Xavantes

19. UHE Armando A. Laydner - Jurumirim

20. UHE Armando de Salles Oliveira - Limoeiro

21. UHE Euclides da Cunha

22. UHE São José

23. UHE Carrapatos

24. UHE Caconde

25. AM Mogi Guaçu

26. UHE Jaguari

27. UHE Paraibuna e barragem de Paraitinga

28. AM Funil

29. AM Batatal
IMAGEM 110. Mapa Usinas Hidrelétricas, Fonte: Arquitetura na CESP, Companhia energética de São Paulo, Nina Maria Jamra Tsukumo, São Paulo, 1994, p. 89

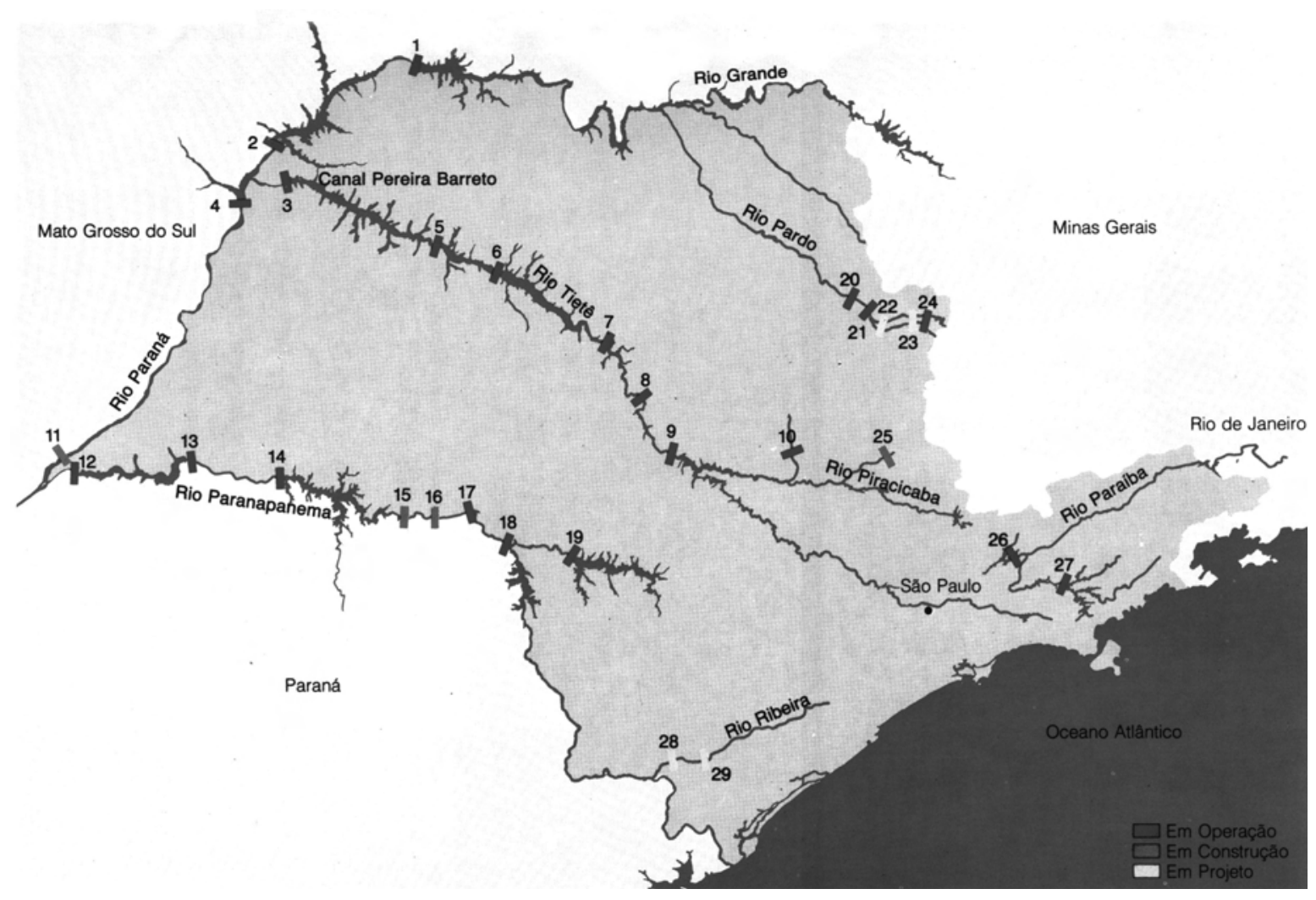




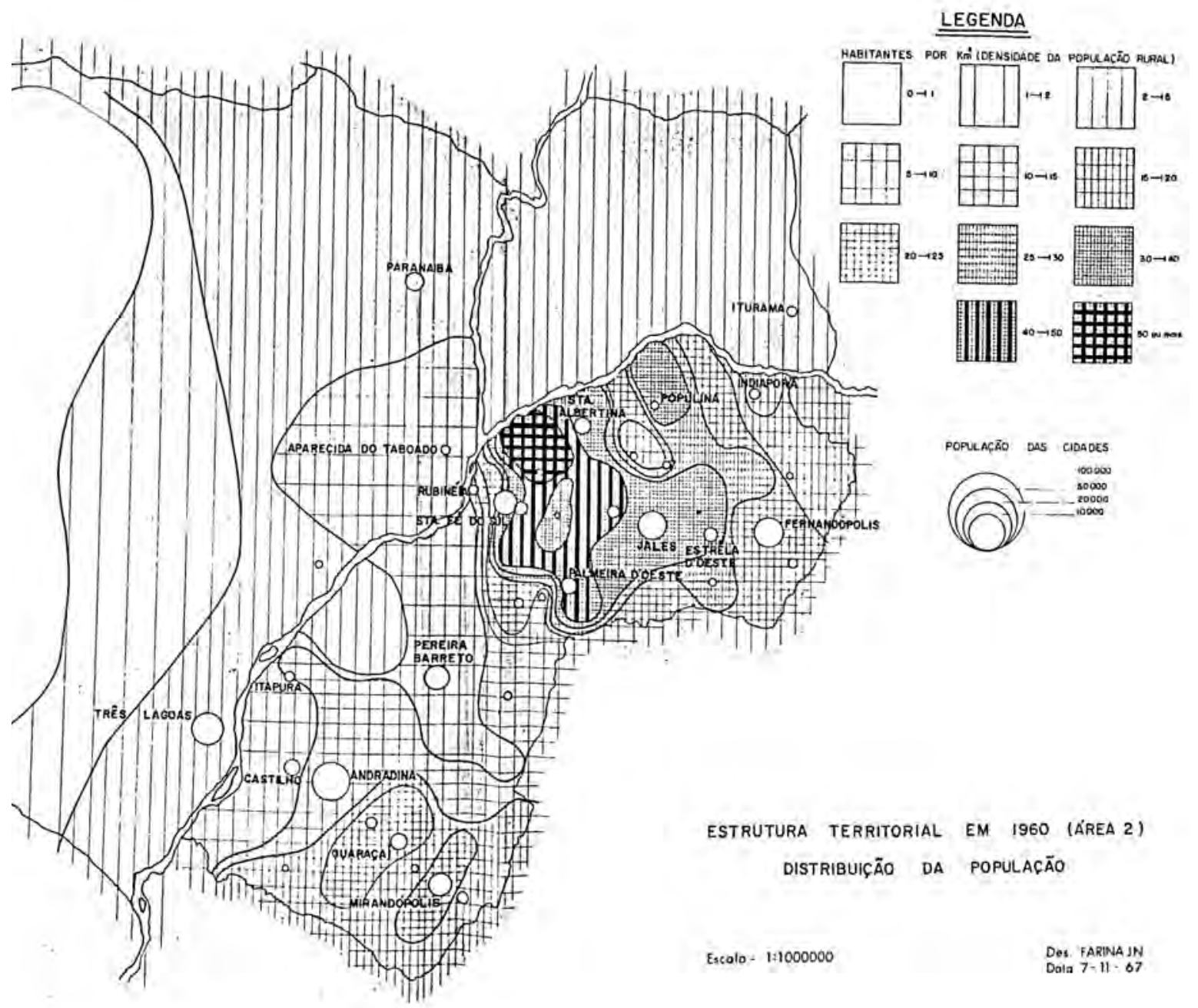

A Divisão de Arquitetura e Urbanismo da empresa, dirigida por Hélio Pasta, ampliou a partir de 1966, assim como a responsabilidade dos arquitetos na definição das partes dos empreendimentos hidrelétricos. Inicialmente responsável pela casa de força, casa de comando, e questões da recuperação da paisagem, a divisão passou a ser responsável pelos acampamentos de operários, vilas de operadores e edificações comunitárias. A partir dos anos 1970, 0 setor de arquitetura trabalhou em equipes multidisciplinares, preocupadas com as questões sócio - econômicas e impactos ambientais nas regiões dos empreendimentos hidrelétricos

\section{PROJETO DE NOVA CIDADE FRENTE} UMA REDE URBANA EXISTENTE

As grandes obras de engenharia por vezes, exigiram a implantação de acampamentos para abrigar seus trabalhadores, que muitas vezes se deslocavam para os locais de trabalho junto de seus familiares. Diante tais circunstâncias,

IMAGEM 111. Relatório Geraldo Vespaziano Puntoni, Aspectos sobre a implantacão da obra da Usina de Ilha Solteira, distribuição dos trabalhadores em núcleos residenciais construídos nas cidades da redondeza, aproveitando-se das estruturas urbanas existentes 
os acampamentos de obra passaram a se caraterizar como verdadeiras cidades, cujo porte e equipamento comunitário os tornaram significativos para a região. Nenhuma obra dessa escala ocorreu sem planejamento, todas contaram com projetos, programação técnica e estudos de viabilidade econômico-financeira nas quais o Arquiteto Geraldo Vespaziano Puntoni dedicou -se de 1970 a 1973 através da CESP (Centrais Elétricas do Estado de São Paulo). Desse modo, com respeito à demanda de mão de obra especializada ou não, foi desenvolvida uma estimativa de seu volume e classificação.

No caso de construções de usinas hidrelétricas (UHE), cuja localização dependeu em grande parte do estudo dos aproveitamentos hídricos dos grande rios, esses acampamentos foram considerados como mero apoio às obras. Era comum encontrar grandes barragens que acabaram sendo construídas em regiões isoladas da rede urbana existente, com baixa densidade demográfica regional. Parte do trabalho do arquiteto Geraldo Vespaziano foi a verificação, através de estudo mais apurados da região, das possibilidades de aproveitamento desses investimentos para um desenvolvimento persistente da região. A experiência na construção de residências para operários organizou-se basicamente em três modelos. As diferentes atuações revelaram uma necessidade de otimização sócio-econômica dos investimentos, no sentido de integrá-los em um quadro de desenvolvimento
IMAGEM 112. Vila Piloto Jupiá, Três Lagoas, 1965, Fonte: www.dee.feis. unesp.br/museu

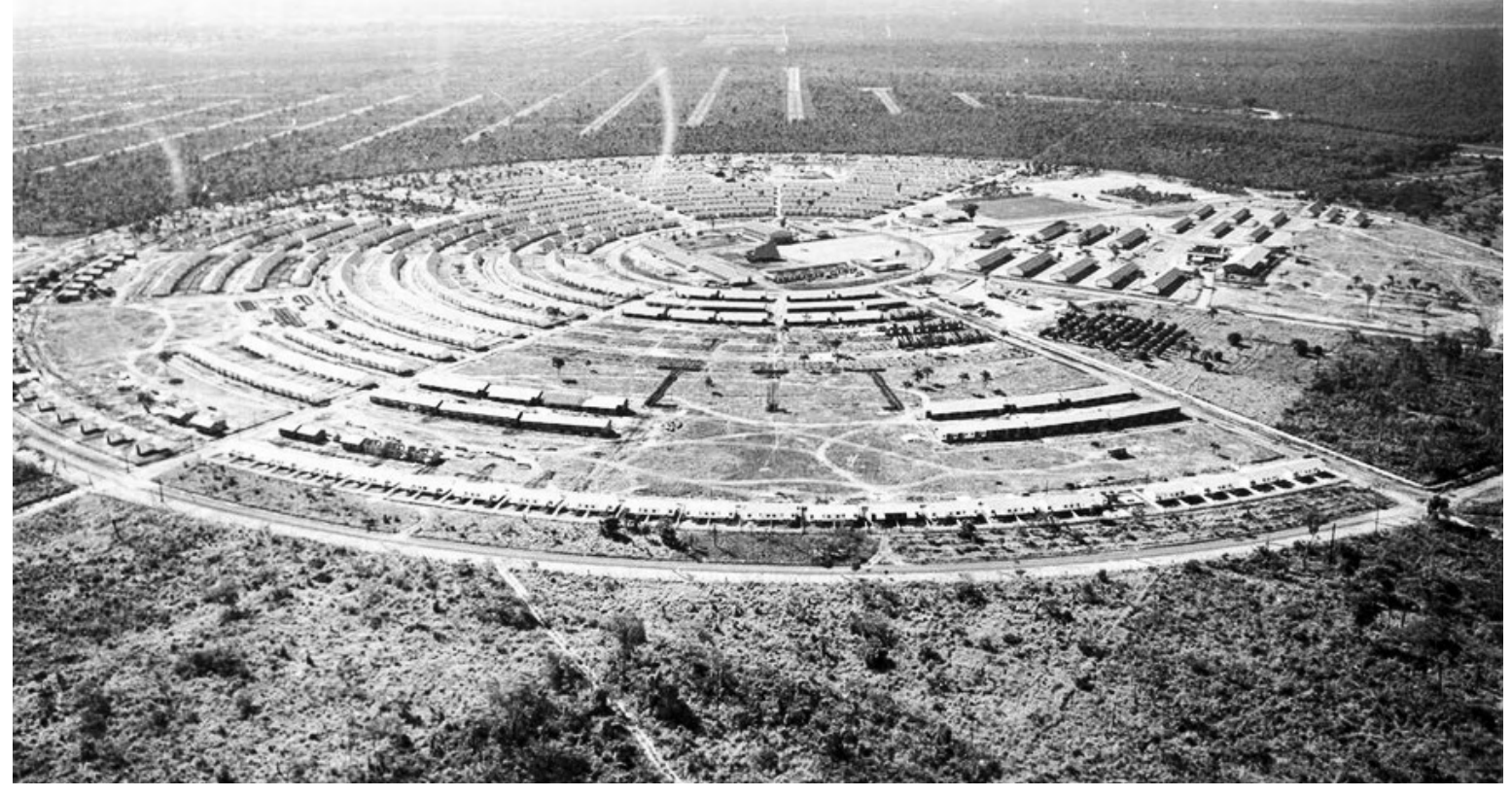



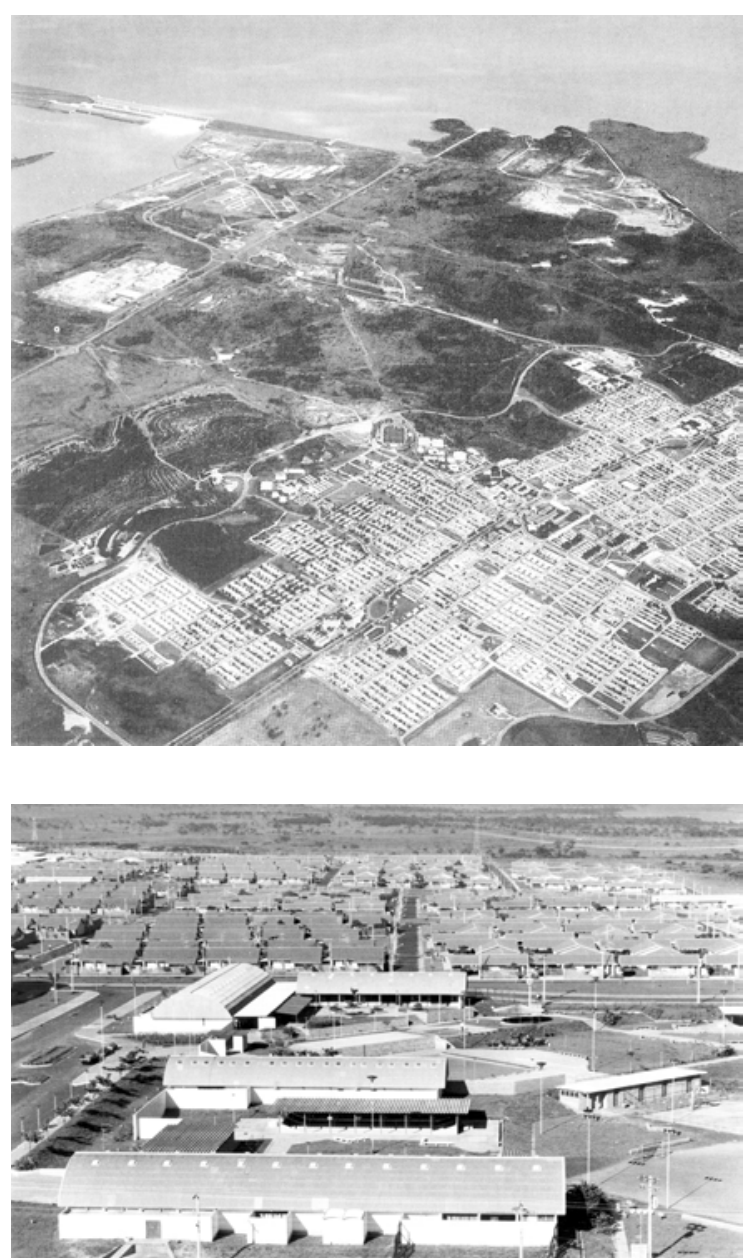

IMAGEM 113. Núcleo urbano permanente, Ilha Solteira, Fonte: Arquitetura na CESP, Companhia energética de São Paulo, Nina Maria Jamra Tsukumo, São Paulo, 1994, p. 102

IMAGEM 114. Idem. p. 103

150 regional. A primeira fase demonstrou a construção de um núcleo residencial perto do canteiro de obras e isolado da estrutura urbana existente. Um marco importante na fase dos primeiros modelos foi a construção do acampamento de Jupiá em 1961, onde foi construído um núcleo residencial autônomo com capacidade para 2.350 famílias, o que correspondia aproximadamente a 11.000 mil pessoas. No auge da obra, em 1968, o número de habitantes chegou a 15.000 pessoas. A vila localizava-se no Estado do Mato Grosso, a $2 \mathrm{~km}$ do canteiro de obras e apenas 3 km da cidade de Três Lagoas (Mato Grosso).

»A vila de Jupiá [...] representa a primeira experiência significativa de assentamento de trabalhadores, pelo porte da obra e pela abrangência de seu planejamento, que incorporou o lado humano e social aos demais aspectos normalmente considerados em obras desse tipo. $\ll^{3}$ 3 Arquitetura na CESP, Companhia energética de São Paulo, Nina Maria
Jamra Tsukumo, São Paulo, 1994, p. 101 plano urbano seguiu um traçado rigidamente radioconcêntrico, descrevendo na avenida perimetral uma circunferência de $984 \mathrm{~m}$ de diâmetro, definindo uma área urbana de 76 ha. A possibilidade de aproveitar a cidade existente como apoio não foi prevista no planejamento, consequentemente a imaturidade em relação a abordagem do problema acabou levando a demolição do núcleo residencial. Mesmo assim o caráter pioneiro desse empreendimento serviu como ponto de partida na conscientização dos problemas sociais, econômicos e políticos envolvidos em obras desse porte.

A segunda fase foi a construção de um núcleo habitacional permanente em regiões onde a rede urbana era rarefeita e impedia a utilização de cidades próximas como apoio. O núcleo, situado em Ilha Solteira, foi equipado com toda a infra-estrutura necessária para seu funcionamento autônomo, tornando-se um polo de desenvolvimento futuro para a região. A situação geográfica e as condições econômico-financeiras eram tais, que julgou- 
-se conveniente construir uma cidade completa e permanente, admitindo-se que as condições da rede-urbana existente eram satisfatórias e que o custo inicial poderia ser recuperado após a conclusão da obra, pressupondo-se que as condições econômicas da região seriam alteradas com a presença de uma »cidade« moderna e altamente equipada. De fato, não existiram no Brasil experiências anteriores de um acampamento de obra dessas proporções, construído com a intenção de permanecer e com uma população constituída por indivíduos dependentes da CESP e das empresas construtoras. Uma outra parcela da população, que não dependia diretamente da CESP, era constituída por comerciantes, profissionais e funcionários públicos, e poderia crescer com tempo.

A terceira fase foi a utilização de uma solução mista, onde parte do núcleo foi fixada na região e a outra parte seria removida após o término das obras. $\bigcirc$ plano de desenvolvimento regio-

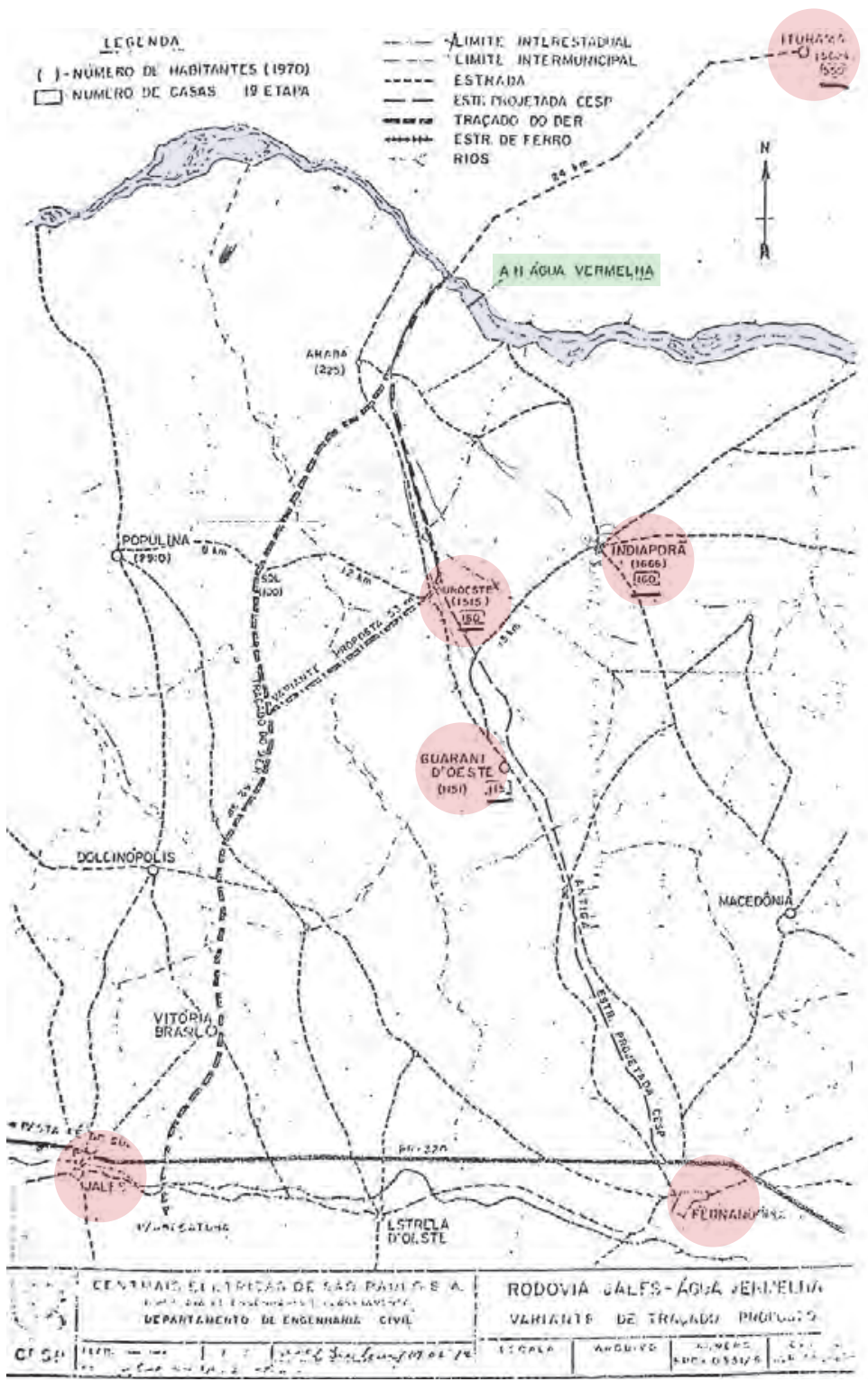


PROJETCS PROPOSTOS, $1971-1975$ E MICRO REGGINO DO PONTAL DO
TRIANGULO MINEIRO (AREA G)

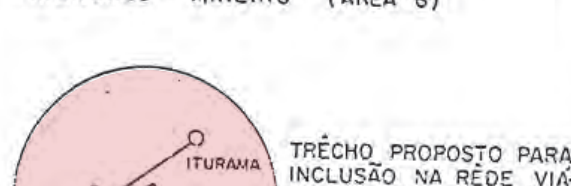
TRECHO PROPOSTO PARA
INCLUSÃO NA REDE VIN-
RIA DO ESTADO DE MI-
NAS GERAIS

$$
\text { A }
$$
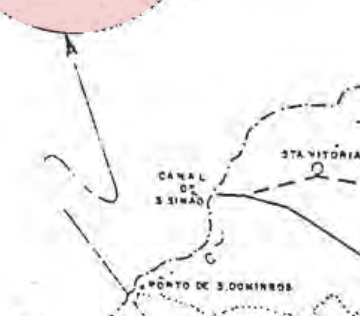

FONTE - GOVÊRNO DO ESTTADO DE MINAS GERAIS, CONSÊLHO ESTADUAL. DE DESENVOLVIMENTO MINAS GERAIS, $1971-1975$, PRESPECTIVAS - TRANSPORTES, JULHO DE IOTO 
IMAGEM 117. Rede Rodoviária Básica - Região UHE Aguá Vermelha,
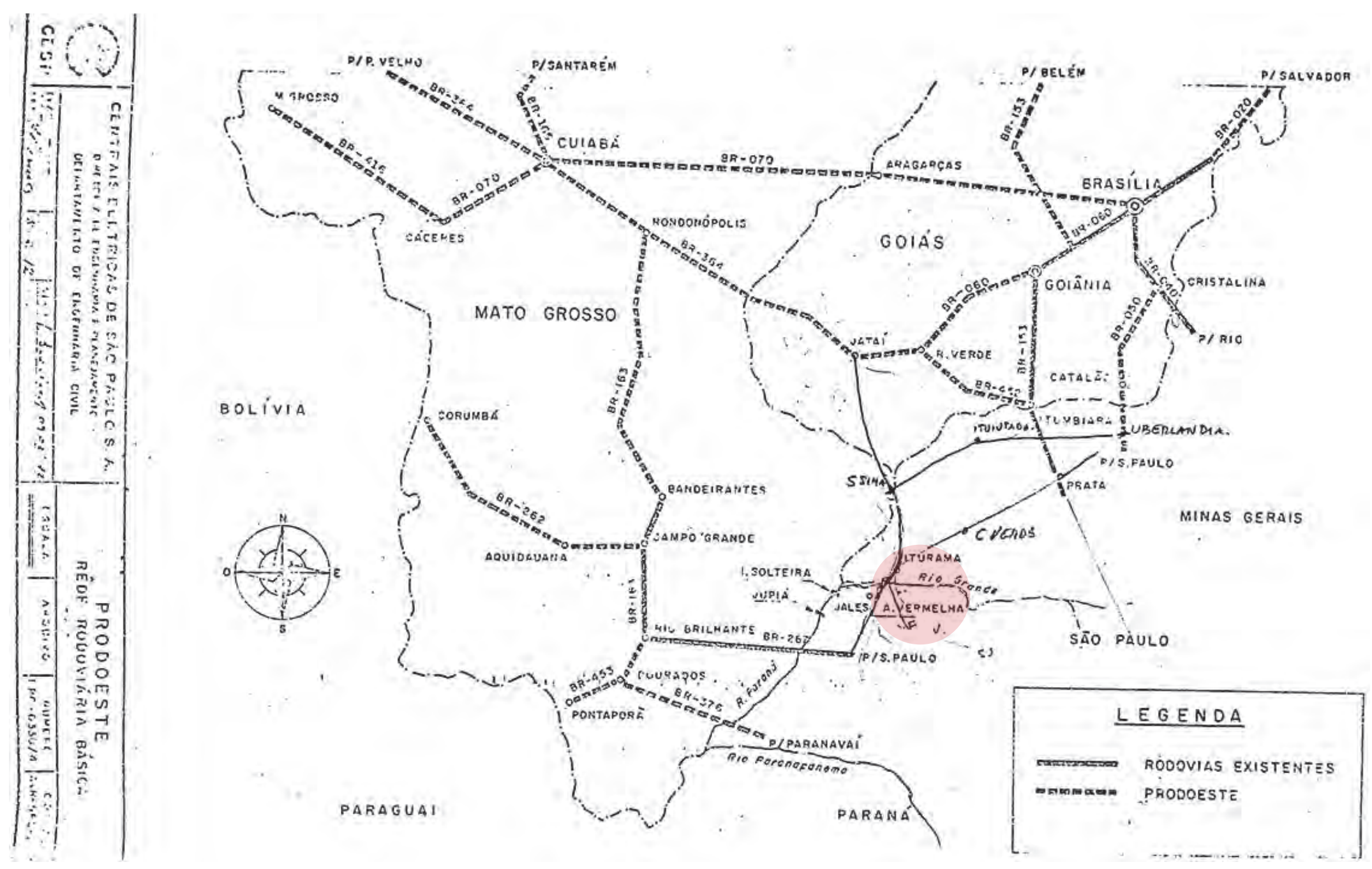

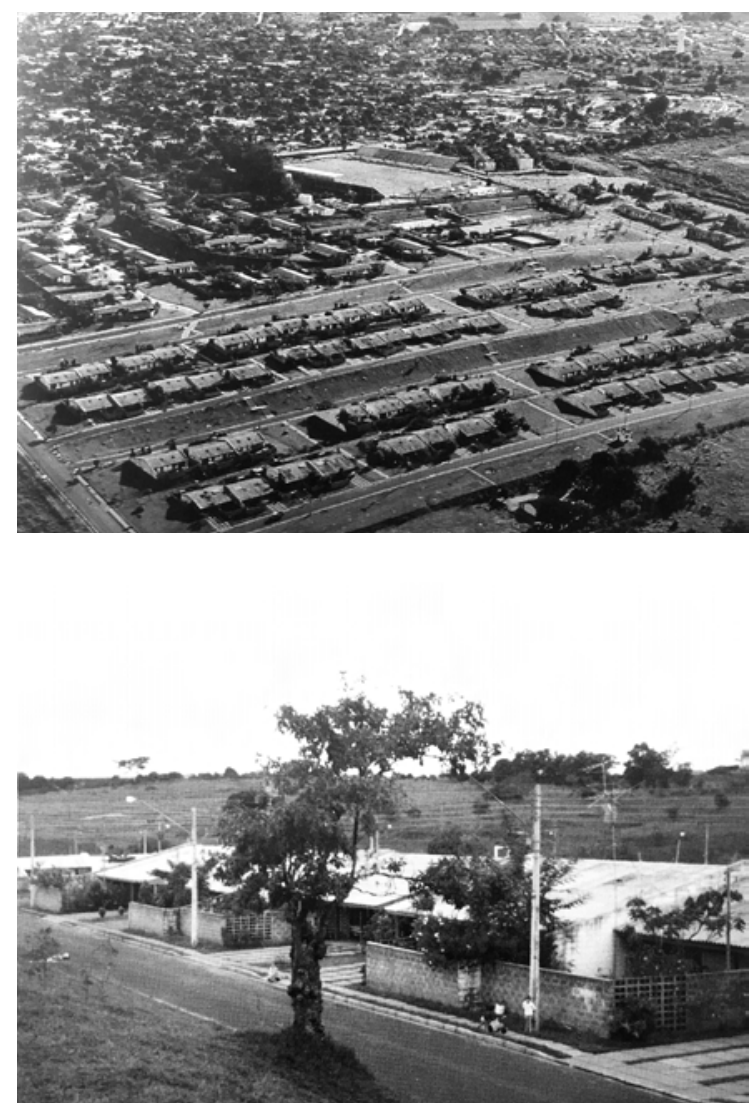

IMAGEM 118. Conjunto residencial em Fernandópolis, Região Água Vermelha, Fonte: Arquitetura na CESP, Companhia energética de São Paulo, Nina Maria Jamra Tsukumo, São Paulo, 1994, p. 102

IMAGEM 119. Idem. p. 105

154 nal, de acordo com as necessidades da empresa, definiu a dimensão da parte permanente do núcleo. A CESP englobava cidades próximas com construções ou reformas de casas, quando a estrutura comportava. $\bigcirc$ conceito da terceira fase possibilitou um investimento maior na infraestrutura da região. Um exemplo dessa experiência é a UHE de Água Vermelha, que teve sua obra iniciada em 1973 e seus projetos desenvolvidos entre 1971 e 1974. As experiências mais recentes da CESP, como por exemplo a Ilha Solteira, mostraram que a metodologia usada na segunda fase (usar as cidades da região como apoio) era a mais indicada. As análises e estudos em campo sobre a região resultaram na escolha de cinco cidades existentes para receber a nova população: Fernandópolis, Guarani D’Oeste, Indiaporã, Ouroeste e Iturama. Através dos estudos elaborados, sobre uma nova rede viária, podemos identificar o objetivo de buscar um apoio urbano maior através das cidades de Fernandópolis e Jales. Na escala mais afastada, São Jose do Rio Preto ganharia mais importância como polo urbano da região noroeste do Estado. Segundo o relatório do Eng.Victor Brecheret Filho, a nova rede viária construída foi fundamental para o desenvolvimento da região.

»Para que a proposta permaneça viável e que o Estado de São Paulo receba parte significativa deste investimento, torna-se necessária a alteração do eixo do trecho final da estrada Jales-Água Vermelha, passando pelo triângulo formado pelas cidades Outroeste, Guarani D'Oeste e Indiaporã, e definidas as ligações destas cidades com a estrada. Esta pequena mudança traria o eixo para o trecho final da primitiva proposta CESP de se estabelecer a ligação Fernandópolis - Água Vermelha. Esta mudança é viável, e não acarreta aumento significativo de percurso, podendo a CESP arcar com o ônus do projeto da nova locação. $\ll^{4}$ (Ver mapa Estudos de Rodovias)

Foram aproximadamente 8.000 trabalhadores envolvidos no desenvolvimento do empreendimento. 1.500 funcionários casados foram manti-

4 Usinas de Água Vermelha, Alojamento da mão de obra. Serviços de Infra-estrutura e apoio atividades propostas para 1972. Eng. Victor Brecheret Filho 
dos nos alojamentos existentes em Ilha Solteira e 4.500 solteiros foram alojados na própria obra, restando 2.000 pessoas para serem abrigadas em casas a serem construídas na região. Em um relatório sobre aspectos da implantação e distribuição dos trabalhadores de Água Vermelha em núcleos residenciais construídos nas cidades da redondeza, o arquiteto Geraldo Vespaziano Puntoni previa o seguinte procedimento:

»Como primeira aproximação, poderemos interpretar os núcleos a serem implantados nas cidades da redondeza, como conjuntos residenciais com caráter definitivo, a serem usufruídos pela CESP durante a construção da usina e depois incorporadas à cidade na forma de um programa tipo »CO$H A B \ll$, realizados e financiados através de convênios a serem estabelecidos com as respectivas entidades. Para seu dimensionamento, o critério inicial que podemos adotar é que esses conjuntos venham a substituir em primeira instância as atuais casas consideradas »ruins«, isto é, precárias, deterioradas. O crescimento efetivo que ocorrer na cidade durante esse período poderá ser absorvido pela livre inicia- tiva ou instalando-se em residências cuja população for atendida pelo novo conjunto - COHAB (CESP).«

Por fim foram construídas 1.005 residências nas cidades de Guarani D'Oeste, Ouroeste, Fernandópolis e Indiaporã, através da ocupação dos terrenos da trama urbana existente. Durante a implantação houve uma preocupação em não romper com o equilíbrio das cidades. Foi promovida uma integração com os novos habitantes às comunidades e cada cidade absorveu uma população compatível com sua potencialidade. Depois das obras da usina, os benefícios gerados pela presença da CESP - estradas, pavimentações, água, esgoto, luz, etc. foram incorporados às comunidades. As habitações e as casas permanentes foram vendidas para a população local, como previsto pelo arquiteto Geraldo Vespaziano Puntoni.

»As habitações foram projetadas para se adequar ao clima das regiões e agenciadas de forma a valorizar os espaços externos de convivências, pro-

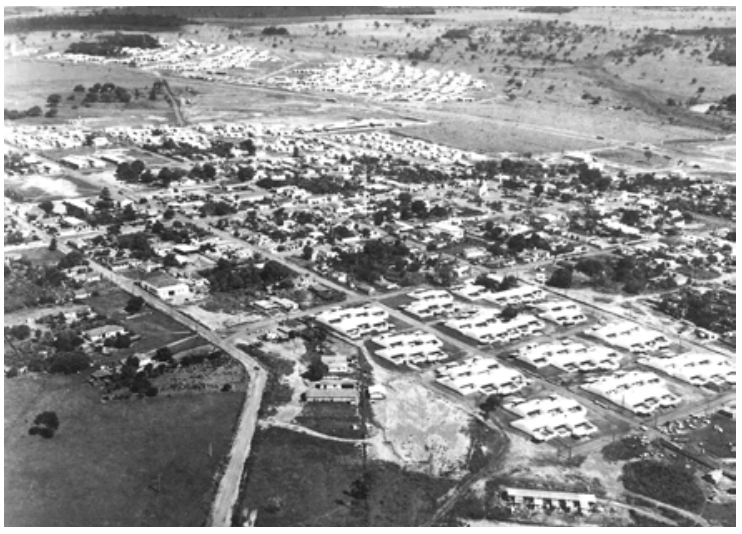

IMAGEM 120. Região Água Vermelha, Casas pré-fabricadas em Indiaporã Fonte: Arquitetura na CESP, Companhia energética de São Paulo, Nina Maria Jamra Tsukumo, São Paulo, 1994, p. 107 
piciando maior interação entre seus moradores. $\ll^{5}$

A maioria das construção foi feita de tijolo e madeira. A ocupação na cidade Iturama (MG), local da construção dos alojamentos na proposta inicial, não foi realizada por questões políticas, obstáculo que levou à construção de um conjunto de 775 casas pré-fabricadas, com $80 \mathrm{~m}^{2}$ de área total, ao lado de Indiaporã. Nessa proposta esteve presente a ideia da desmontabilidade e reutilização dos componentes. A questão do provisório influenciou em algumas caraterísticas da implantação, como por exemplo a ausência de qualquer terraplanagem na área, um desenho viário acomodado ao terreno natural e uma drenagem natural na superfície, possibilitada pela elevação das casas em relação ao terreno existente. As casas desse conjunto foram reimplantadas na Cidade Primavera.

5 Arquitetura na CESP, Companhia energética de São Paulo, Nina Maria Jamra Tsukumo, São Paulo, 1994, p. 106
Os estudos sobre as novas cidades frente uma rede urbana existente exigiram ainda uma consideração final. $O$ arquiteto Geraldo Vespaziano Puntoni tinha consciência que a CESP, como empresa estatal, tinha suas obrigações com a sociedade, além da produção de energia.

»Vale a pena indagar se não seria mais correto, não se preocupar unicamente com os aspectos técnicos da exploração dos recursos naturais, mas sim com aqueles do desenvolvimento da própria região como um todo. Integrado, avaliado nos seus aspectos sócio-econômicos e ecológicos. « ${ }^{6}$

Isso é o mesmo que dizer que é mais do que necessário que um planejamento da região preceda os estudos de aproveitamento energético ou qualquer outro empreendimento dessa natureza, que envolve a ocupação do território. Para $o$ arquiteto foi fundamental ter em mente a importância de definir a estrutura da rede

6 Geraldo Vespaziano Puntoni, Relatório CESP, Projeto de Cidades Novas, 1973, São Paulo 
urbana, que possibilitasse uma opção mais segura quanto a implantação de acampamentos de obras ou a utilização das cidades existentes, para que se constituam em apoios efetivos durante e principalmente depois das obras. Vale a pena ressaltar a crítica do arquiteto Geraldo Vespaziano Puntoni em relação à metodologia do desenvolvimento e a falta das possibilidades de intervir no processo.

»A falta de uma metodologia adequada para a abordagem dos problemas (relativos ao planejamento urbano), leva o técnico a agir empiricamente, num esforço brutal de auscultar a dinâmica dos elementos que transformam a realidade, que poderia não constituir uma aberração, se fosse possivel acompanhar todo o processo de implantação, intervindo-se oportunamente para estabelecer as correções necessárias. «7

Todavia podemos encarar a época como um momento significativo no desenvolvimento de novos ramos para a »figura« do arquiteto, cuja participação nos empreendimentos revelou- se como uma força integradora, capaz de articular diversas áreas de conhecimento. A contribuição arquitetônica não faz sentido sem essa interação entre as disciplinas, que buscam complexas soluções ecológicas, sócio-econômicas e urbanísticas, sem esquecer a engenharia que tem como objeto mais visível a usina hidrelétrica.

\section{ARQUITETURA E A USINA HIDRELÉTRICA}

»Nossos olhos são feitos para ver as formas sob a luz. As formas primárias são as formas belas porque se leem claramente. Os arquitetos de hoje não realizam mais as formas simples. Operando com o cálculo, os engenheiros usam formas geométricas, que satisfazem nossos olhos pela geometria e nosso espírito pela matemática; suas obras estão no caminho da grande arte. $\|^{8}$

8 LE CORBUSIER, Por uma Arquitetura, Editora Perspectiva, $5^{\circ}$ Edição 1998 

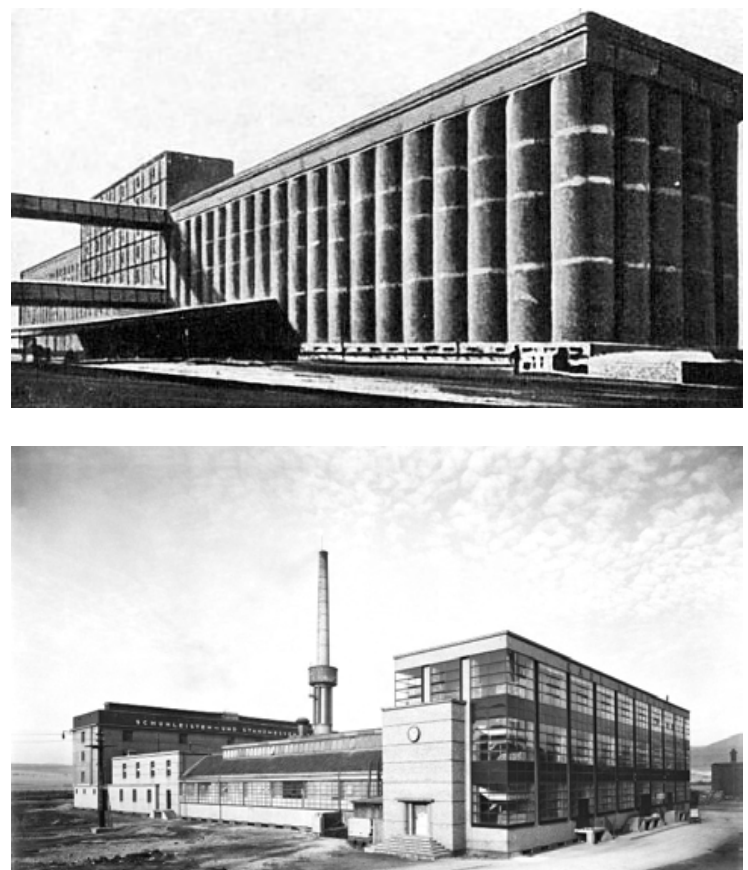

IMAGEM 121. LE CORBUSIER, Fonte: Por uma Arquitetura, Editora Perspectiva, 5 Edição, 1998, p.14

IMAGEM 122. GROPIUS, Walter, Fagus Werk, Alfeld an der Leine, 1911, Fonte: https://de.wikipedia.org/wiki/Fagus-Werk
A arquitetura proclamada pelo arquiteto Le Corbusier, ou a obra icônica do Fagus Werk, realizada pelo arquiteto Walter Gropius, representaram o discurso da arquitetura para uma nova sociedade industrial. A arquitetura moderna europeia da década 20 pode ser entendida como pano de fundo para as experimentações arquitetônicas das Usinas Hidrelétricas da CESP, fortemente impregnadas pelo racionalismo técnico. Sem dúvida a arquitetura das UHE, com todos seus componentes técnicos, sua função de abastecer uma sociedade moderna e sua materialidade com as renovações técnicas construtivas (que incorporava o ferro fundido e o concreto armado) representou a linguagem do ideário moderno dos ano 20.

Mesmo assim, podemos considerar como início do processo industrial no país as primeiras tentativas de pensar o Brasil como Estado e como Nação. O primeiro momento de pensar e aperfeiçoar a técnica iniciou-se através dos primeiros engenheiros militares, enviados pela coroa portuguesa com o objetivo de compreen- der o novo território, e não para constituir uma nova sociedade civil. Os engenheiros militares dessa época, coincidentemente a maioria dos engenheiros da CESP, eram funcionários públicos. Na segunda metade do século XIX foram criadas as primeiras escolas técnicas superiores do Brasil: a Escola Politécnica do Rio de Janeiro (1872), a Escola de Minas e Metalurgia de Ouro Preto (1876), e a Escola Politécnica de São Paulo (1894). Os primeiros engenheiros formados dedicaram-se principalmente as obras de infra-estrutura, como por exemplo portos e estradas; além disso foram responsáveis pelos levantamentos topográficos. As repercussões dos estudos topográficos resultaram na criação da Comissão Geológica, Geográfica e Hidrográfica do Estado de São Paulo (1886 a 1931), cuja tarefa se resumia a mapear o Estado. Os resultados foram significativos para as primeiras estimativas do potencial energético dos grandes rios de São Paulo e considerado como documento básico para os estudos da Comissão Interestadual da Bacia do Paraná-Uruguai (mencionado no capítulo DOP, p.44), que elaborou 
em 1952 estudos sobre o aproveitamento do potencial hidráulico do Salto do Urubupungá, no Rio Paraná. Assim surgiram, a partir de 1950, as companhias estatais energéticas, como Uselpa, Celusa, Belsa e outras, que constituíram, em 1966, a CESP. Mas o que interessa é que essas companhias, seguidas pela CESP provavelmente por conta de seu caráter público, procuraram contratar os melhores auxílios intelectuais do país. Assim, muitos professores, cientistas e engenheiros foram chamados para participarem dos trabalhos, como Ernest Robert de Carvalho Mange e Anhaio Mello, ambos professores da FAU ou Milton Vagas e Lucas Nogueira Garcez da Politécnica. Nessas condições, criadas pelos avanços tecnológicos, que não são nada além de estudo acompanhado de conhecimento científico das operações técnicas, podemos afirmar que durante as décadas de 50 a 70 a tecnologia brasileira, pelo menos na área da construção, atingiu seu estágio de maturidade.

A arquitetura da CESP seguiu dois caminhos convergentes: $\bigcirc$ arquiteto Hélio Pasta que criou

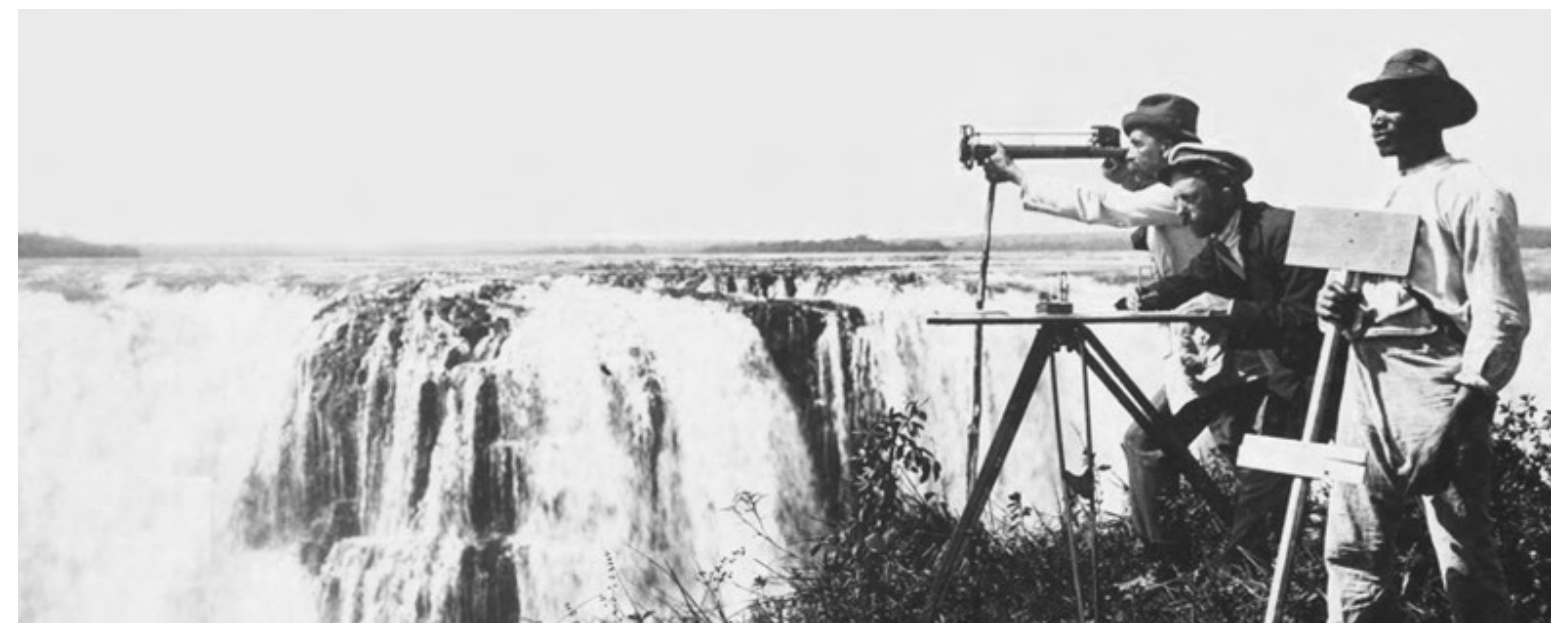

IMAGEM 123. Comissão Geográphica e Geológica 1886 - 1936, Salto de Patos Rio Grande, 1910, Fonte: http://igeologicosp.blogspot.com.br 


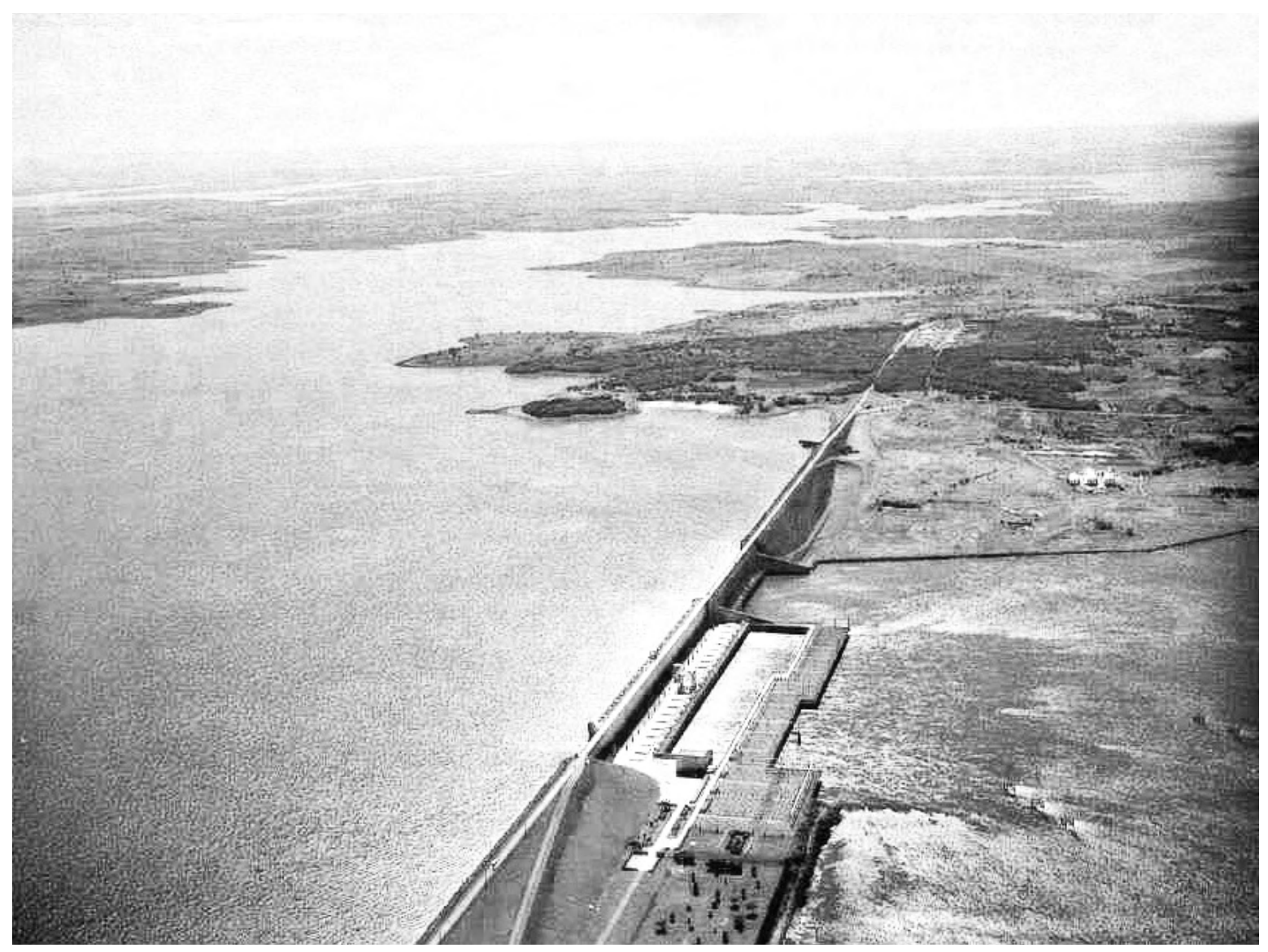

IMAGEM 124. UHE Ilha Solteira, Rio Paraná, 1973, Fonte: http://professormarcianodantas.blogspot.com.br/2015/01/regiao-hidrografica-do-parana.html um setor de arquitetura na CESP, e o engenheiro Ernest Robert de Carvalho Mange (19222005). Mange formou-se engenheiro civil em 1945, pela Escola Politécnica, e fez estágio no escritório de Rino Levi. Recém-formado, Mange conseguiu uma bolsa do governo francês para trabalhar no ATBAT, escritório executivo da Unidade de Habitação de Marselha, do franco-suíço Le Corbusier. (VIANNA 2015)

Segundo Vespaziano Puntoni, Ernest Mange trabalhou em seu próprio escritório, Planemark, começando com pequenos projetos residenciais no setor das UHE, em 1953, até chegar em projetos de escala maior, como algumas usinas. Em Jupiá foi responsável pelos projetos arquitetônicos de casa de força, subestação, eclusa e casa de comando.

»[...] Eu gostava muito do Ernest Robert de Carvalho Mange, só não gostei de ir no escritório dele. Escritório climatizado a $10^{\circ} \mathrm{C} !{ }^{9}$

9 Entrevista, Geraldo Vespaziano Puntoni, 04.07.2016 
Como professor da Faculdade de Arquitetura e Urbanismo de São Paulo, Mange era um profissional equipado e com grande conhecimento na área, além de possuir uma sensibilidade para arquitetura. Através da incorporação de sua formação no imaginário moderno, Mange restituiu a relação entre a arquitetura moderna com a instalação industrial. Hugo Segawa perguntou no seu desdobramento sobre arquitetura em hidrelétricas:

"O que é o »edifício« numa instalação hidrelétrica? A hidrelétrica limita-se apenas à usina? «

Segawa mesmo respondeu a pergunta dizendo que o significado tradicional de »edifício« se esmaece no meio da complexidade tecnológica-urbanística-ambiental do empreendimento hidrelétrico, subvertendo a função do arquiteto em uma atuação multifacetada (SEGAWA, 1998). Estamos de acordo com a segunda parte da resposta, pois o arquiteto transformou-se pelos desafios da abrangência de sua profissão frente as UHE, em um profissional que permeia

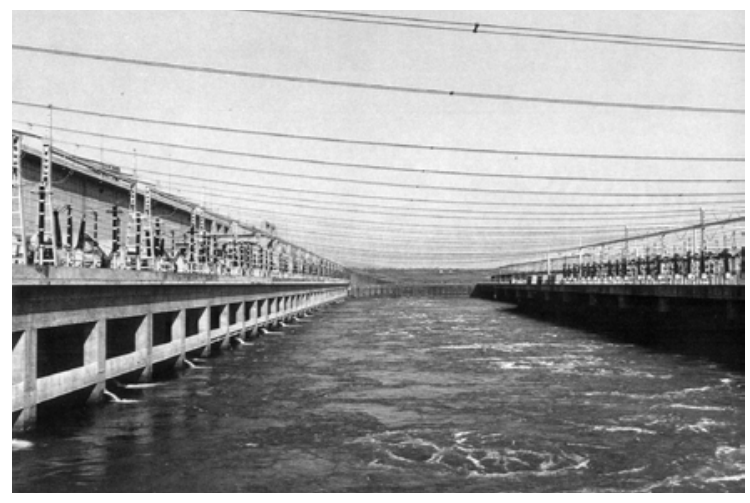

IMAGEM 125. UHE Ilha Solteira, Casa de força e subestação, Fonte: Arquitetura na CESP, Companhia energética de São Paulo, Nina Maria Jamra Tsukumo, São Paulo, 1994, p. 54

IMAGEM 126. UHE Ilha Solteira, Vertedouro, Fonte: Arquitetura na CESP, Companhia energética de São Paulo, Nina Maria Jamra Tsukumo, São Paulo, 1994 , p. 55

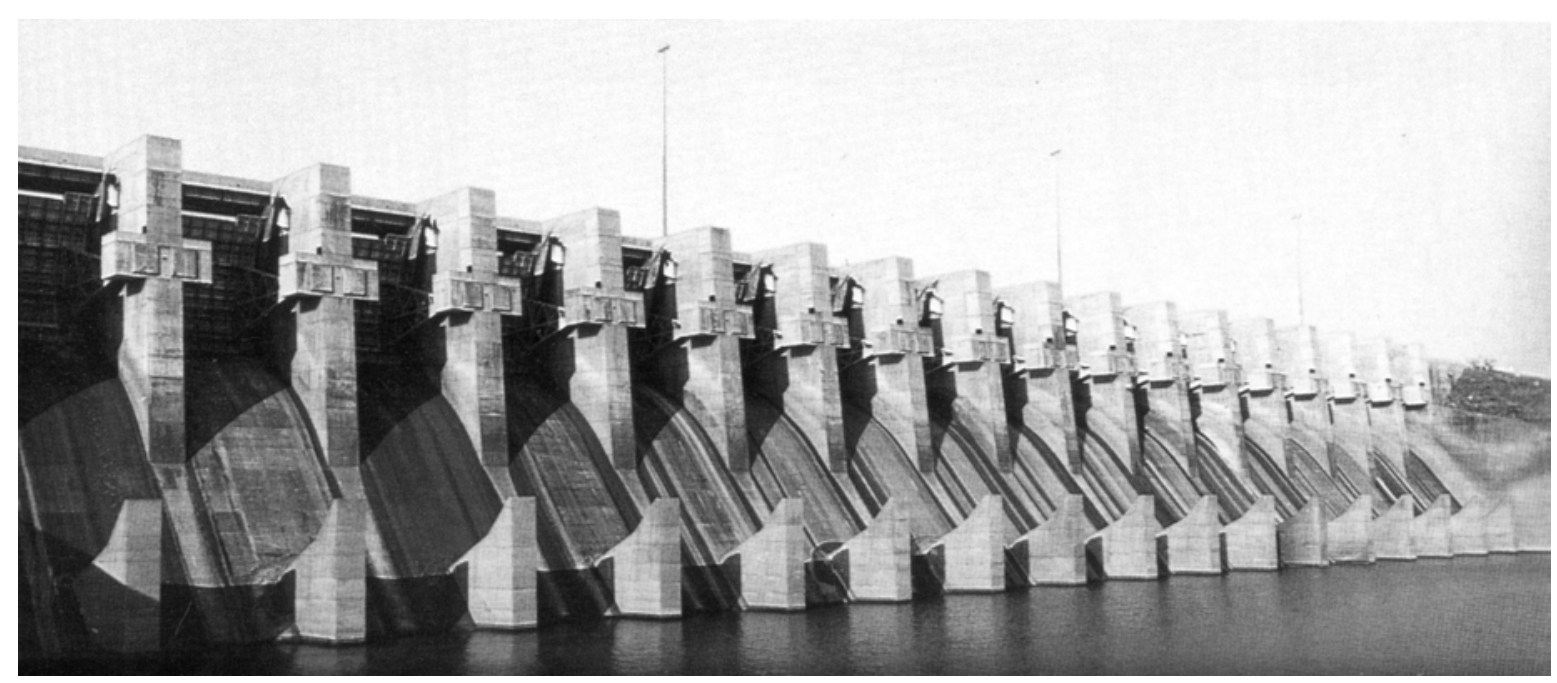


entre diversas disciplinas. A arquitetura das hidrelétricas e seus várias níveis de atuação, coincide com o ideário moderno, cuja síntese foi a condição de abrangência totalizadora, também um resultado da revolução industrial. Por outro lado, talvez não seja verdade, que o »edifício«, no seu sentido tradicional esmaeceu por causa de sua complexidade. $O$ projeto da UHE Ilha Solteira, desenvolvido pelo arquiteto Ernest Robert de Carvalho Mange, implicou em um avanço na interpretação da UHE, onde o edifício, com todos os seus componentes, forma a barreira. A barragem, nada mais é do que uma linha reta que separa duas águas, de dois níveis diferentes. Todos os seus equipamentos e componentes de geração de energia estão integrados em uma barreira de concreto armado que se estende por $984,50 \mathrm{~m}$. A transformação de um conjunto de edifícios em um edifício único, que se une com a paisagem de tal forma, sem diminuir a radical racionalidade, é do nosso ponto de vista uma concepção marcante no desenvolvimento da arquitetura e do »edifício« das usinas hidrelétricas.
Nesse contexto é importante destacar a importância do paisagismo na construção das UHE. Roberto Coelho Cardozo foi a figura chave para a »escola paulista de paisagismo«, pois foi ele quem introduziu o paisagismo no curso da Faculdade de Arquitetura e Urbanismo (FAU) através do convite de Vilanova Artigas. Segundo Geraldo Vespaziano Puntoni, Roberto Coelho Cardozo foi chamado para participar da recuperação da paisagem no entorno das usinas e fez parte da equipe de Hélio Pasta. Com sua participação, fortaleceu a ideia de buscar a melhor integração possível entre arquitetura e paisagem, ou seja, a integração da máquina ao território. O paisagismo ganhou um papel central na discussão da implantação das Usinas Hidrelétricas e influenciou diretamente a arquitetura do empreendimento, de forma a integrar as demais estruturas na paisagem, reforçando a escala humana na nova paisagem criada. Outros aspectos que nortearam o projeto paisagístico foi a intenção de diminuir ao máximo o impacto, transformar a paisagem e tentar evitar a alienação completa do ambiente conhecido. 

Alllins

[Recorte 1973 - 1979$]$
EMURB - Empresa Municipal de Urbanização

[Recorte 1970 - 1973]

(1) KAM

[Recorte 1967-1970]

CECAP - Caixa Estadual de Casas para o Povo

[Recorte $1963-1967]$

FECE - Fundo Estadual de Construções Escolares

[Recorte 1961 - 1990]

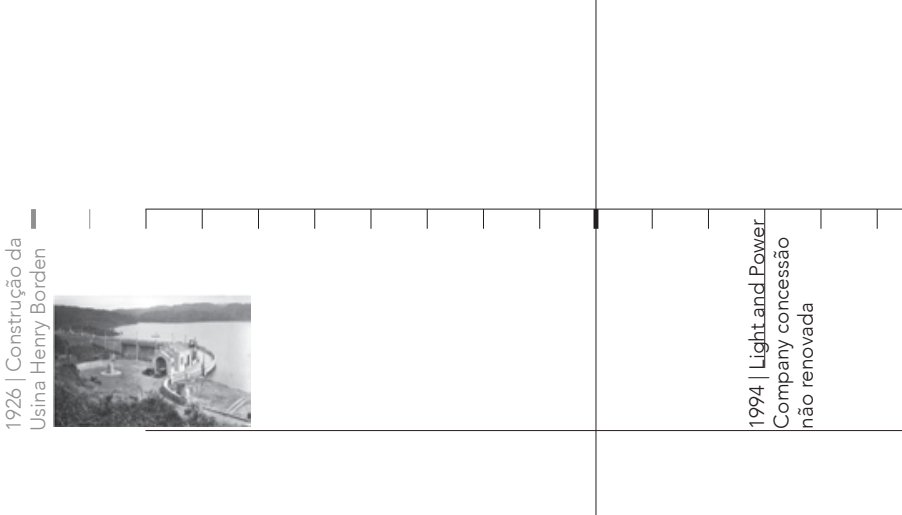

W औ औ

ars

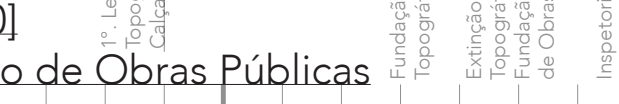

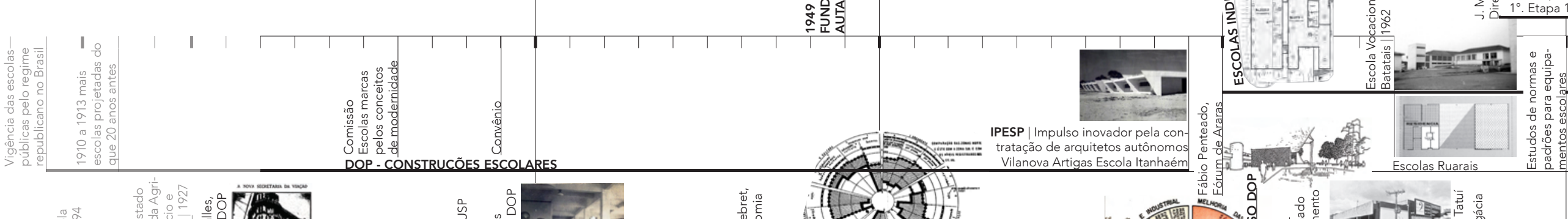
20111 111

$$
\int_{i}
$$

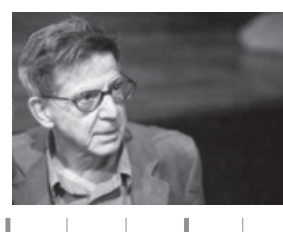

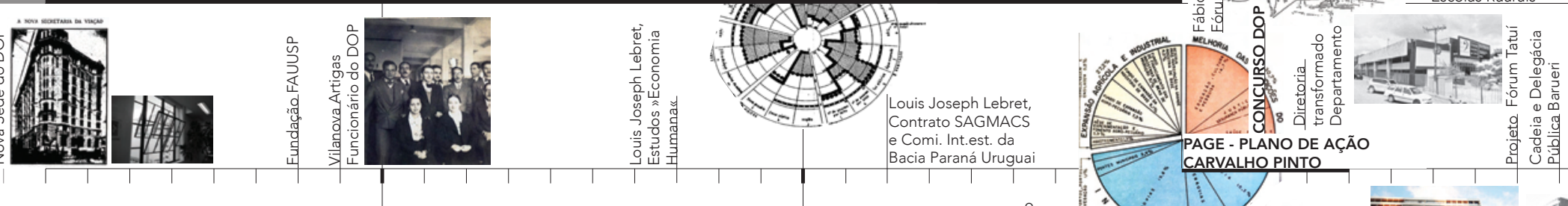





\section{CAPÍTULO 04 - CENTRAIS ELÉTRICAS DO ESTADO DE SÃO PAULO}

\section{LISTA DE PROJETOS}

Administração Regional de Ilha Solteira

Grupo de Planejamento da Administração

Regional de Ilha Solteira

Usina de Água Vermelha, Barragem no Rio

Grande, Divisa do Estado de São Paulo com o

Estado de Minas Gerais

Administração Regional de Ilha Solteira

Apae Associação de Pais e Amigos dos

Excepcionais
Matadouro de Ilha Solteira

1970

[Projeto não executado]

Plano Diretor de Desenvolvimento Integrado

do Município de Pereira Barreto, São Paulo

Planejamento das residências, acampamento

$1971-1972$ para os trabalhadores

Conjunto residencial e comercial de llha Sol-

teira [Projeto realizado, com arquiteto Ricardo

Chahin]

Edifício da Escola da Apae - Fernandópolis, SP

1973

[Projeto não executado] 



\section{CAPÍTULO 04 - CENTRAIS ELÉTRICAS DO ESTADO DE SÃO PAULO}

\section{BIBLIOGRAFIA}

Obras de referência do arquiteto Geraldo Vespaziano Puntoni: Acervo particular do arquiteto

BENEVOLO, L. As origens da urbanística moderna. São Paulo: Perspectiva, 1983

CESP, Arquitetura na CESP, Companhia Energética de São Paulo, 1994

CESP Conta sua História, 1985, São Paulo. Anais... São Paulo: CESP, 1987

KUHL, J.C.A., DINIZ, R.O., FERRAZ, V.M.B (org.). CESP: pioneirismo e excelência técnica. São Paulo: FPHESP, 2002.

OLIVEIRA, A.C.N.; SCARBOZA, B.C.; RODRIGUES, J.A. Vilas temporárias e permanentes como estrutura pra construção de usinas hidrelétricas. São Paulo: CESP, 1984.
PASTA, Hélio; DIVISÃO de Arquitetura e Urbanismo. A arquitetura nas UHE's: a experiência da CESP. São Paulo: CESP, 1985.

PLANEJAMENTO em Urubupungá: acampamento e vila de operadores da usina de Jupiá. Acrópole, São Paulo, v.25, n.289, p.:1-11, dez. 1962.

REIS FILHO, Nestor Goulart. Dois Séculos de Projetos no Estado de São Paulo, Grandes Obras e Urbanização. Volume III, 1930- 2000. Edusp, imprensaoficial, 2004

SEGAWA, Hugo. Arquiteturas no Brasil 19001990. São Paulo: Edusp، 1999.

VIANNA, M. P. Núcleos residenciais da CESP: o processo de desmonte. 2006. Dissertação (Mestrado) - Escola de Engenharia de São Carlos, Universidade de São Paulo, São Carlos, 2006. 


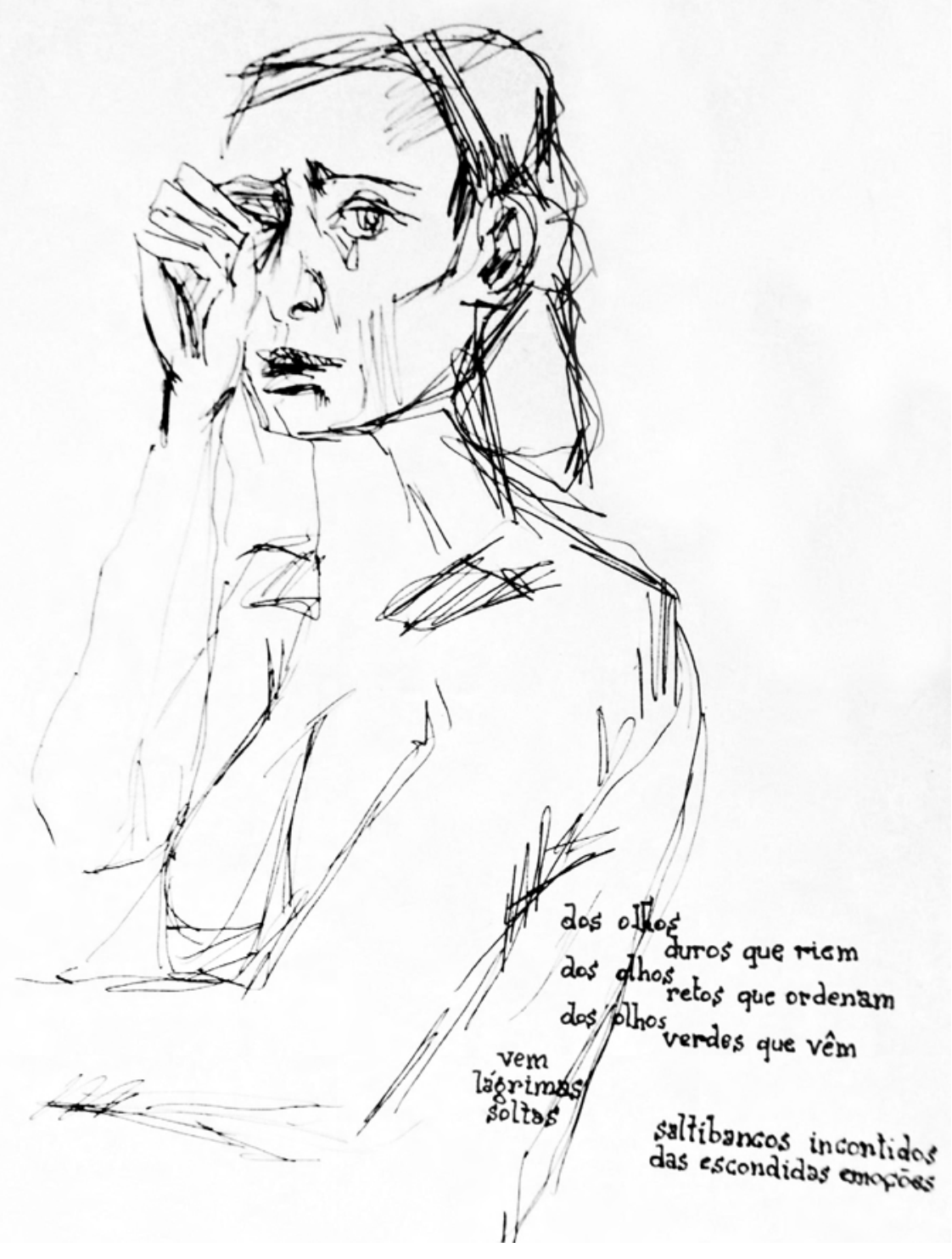




\section{[O ARQUITETO \& A CIDADE]}

CAPÍTULO 5 | RECORTE 1973 - 1979

processo de construção das usinas hidrelétricas, retratado no capítulo anterior, atingiu através de seus componentes de infra-estrutura urbana uma escala que contribuiu para a construção de um país em busca de um avanço sócio-econômico através da cooperação entre ciência, indústria e políticas públicas. Geraldo Vespaziano Puntoni contribuiu como funcionário público nesse esforço de pensar essa região como Estado e como Nação, por isso, o capítulo se chama »O Arquiteto e o País«.

○ capítulo a seguir, „○ Arquiteto e a Cidade», retrata a experiência de Geraldo Vespaziano Puntoni durante sua atuação como servidor público na Empresa Municipal de Urbanização - EMURB. O Arquiteto atuou de 1973 a 1979 nessa empresa, durante uma época que era considerada produtiva, gerando contribuições no campo da reurbanização para uma cidade metropolitana mais adequada.
O objetivo desse capítulo é investigar a relação entre $\mathrm{o}$ arquiteto como profissional público e a construção da cidade. $\bigcirc$ plano de pesquisa introduz a pergunta: „Qual é a função do arquiteto na construção da cidade?«. Nesse capítulo pretende-se evidenciar a estratégia desse órgão público e a compreensão do arquiteto sobre o espaço urbano construído nos anos em questão. A ideia é avançar na compreensão das políticas públicas urbanas desta época e investigar quanto esse intuito contribuiu para a formação do arquiteto na constituição do espaço urbano.

A EMURB surgiu através do Plano Urbano Básico - PUB, criado pelo engenheiro Figueiredo Ferraz durante sua gestão como prefeito, de 1971 a 1973, a fim de que o órgão obte-se maior autonomia para agir diante da concepção e realização de uma obra pública. Destacam-se na zona central da cidade de São Paulo as principais obras realizadas pela empresa: a reestru-
IMAGEM 127. Desenho Geraldo Vespaziano Puntoni, 1962, Fonte: Arquivo do Sílvio Breno de Souza Santos. 


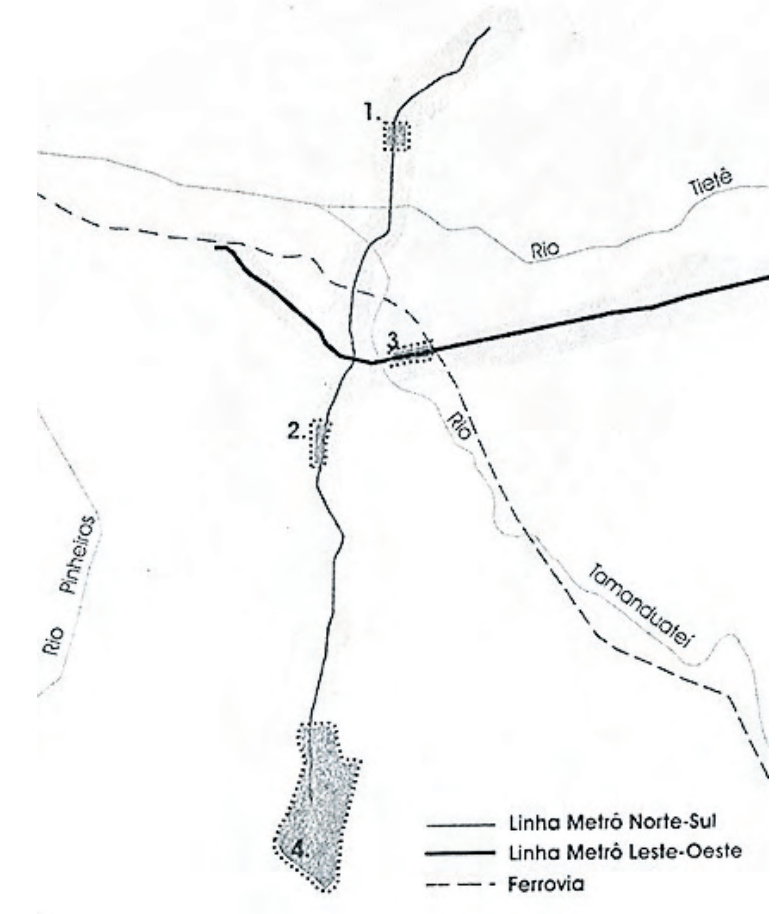

1. CURA Santana

2. Projeto Vergueiro

3. CURA Brás

4. CURA Jabaquara

IMAGEM 128. Localização dos projetos de reurbanização da EMURB em relação às linhas Norte-Sul e Leste-Oeste do Metrô. Fonte: ANELLI, Renato, Plano e conformação da base da metrópole: Redes de mobilidade paulista, 2011, p.41

172 turação do Edifício Martinelli e o Palácio das Indústrias, as reurbanizações do Vale do Anhangabaú e a conversão de vias centrais em ruas de pedestres. Além dos projetos na área central da cidade, foram desenvolvidos projetos relacionados ao Metrô. Sendo ambas as instituições de caráter municipal, foi estabelecida uma divisão de atribuições; enquanto o Metrô era responsável pelo planejamento das linhas e pelo projeto das estações e demais equipamentos operacionais, a EMURB se ocupava de planos de reurbanização das áreas diretamente servidas pela rede, próximas às estações e ao longo das linhas. A EMURB planejou reurbanizações que permitissem a sua comercialização com lucros, os quais deveriam amortizar os elevados custos de implantação da rede.

\section{PROJETOS DE REURBANIZAÇÃO DA EMURB}

Após o abandono do PUB durante a gestão de Paulo Maluf na prefeitura, o prefeito Figueiredo Ferraz recuperou algumas das suas propostas.
Roberto Cerqueira César, também professor de Geraldo Vespaziano Puntoni na FAU USP, foi encarregado de gerir a EMURB (Empresa Municipal de Urbanização), para agilizar os processos executivos municipais nas ações de reurbanização, segundo Domingos Teodoro de Azevedo.

"Quem criou a EMURB foi o engenheiro Figueiredo de Ferraz. Ele criou um órgão para poder agir, algo que não existia. Uma obra pública que exigia muita ação e diversas participações, a EMURB assumiu tudo, fez tudo junto e ficou tudo mais em conta. Quem teve essa ideia foi talvez o Lúcio Gregori, Primeiro Presidente da EMURB - Empresa Municipal de Urbanização foi o Roberto Cerqueira César (1917-2003). $\aleph^{1}$

Além disso Cerqueira César foi responsável pelo Plano Diretor de Desenvolvimento Integrado (PPDI), o qual orientou a Lei de Zoneamento e o Plano de Vias Expressas. Um dos aspectos man-

1 Entrevista, Clementina Delfina de Ambrosis, Domingos Teodoro de Azevedo Marques e Geraldo Vespaziano Puntoni, 26.05.2014 
tidos do PUB foi a permissão do adensamento e a verticalização ao longo das linhas Norte-Sul e Leste-Oeste do Metrô, definindo a liberação de mais áreas verdes para uso coletivo com a organização da circulação e dos estacionamentos, de modo a eliminar conflitos de fluxos. Em vez de uma renovação urbana espontânea, que naturalmente ocorreria pela valorização da área ao longo das linhas de metrô, o Zoneamento do PDDI era a base legal que articulava a operação, definindo as áreas das estações de Metrô como Zonas de Uso Especial. Em 1973, um conjunto de leis regulamentou esses projetos de reurbanização, permitindo à EMURB agir na desapropriação dos imóveis abrangidos. Clementina Delfina de Ambrosis, Domingos Teodoro de Azevedo Marques e Vespaziano Puntoni lembraram o momento, em 1976, quando a EMURB ganhou a causa:

»Nós fomos até o Tribunal Federal e ganhamos, 5 a 4. Assim começou a renovação urbana na cidade de São Paulo. De repente podia-se desapro- priar terra para uma reforma urbana. $\ll^{2}$ (Domingos)

»Antes o Governo só podia desapropriar áreas para grupos escolares, e não para renovação urbana. $\ll^{2}$ (Clementina)

»No projeto CURA do EMURB conseguimos inclusive desapropriar as áreas por causa disso. $\ll^{2}$ (Vespaziano)

Enquanto o Metrô era responsável pelo planejamento das linhas e pelo projeto das estações, a EMURB se ocupava de planos de reurbanização das áreas diretamente servidas pela rede. A EMURB atuou em conjunto com a Companhia do Metrô na desapropriação de grandes áreas próximas às estações e ao longo das linhas, promovendo reurbanizações que permitiam a sua comercialização com lucros, os quais deveriam englobar os elevados custos de implantação da rede. De acordo com Geraldo Vespazinao Puntoni:

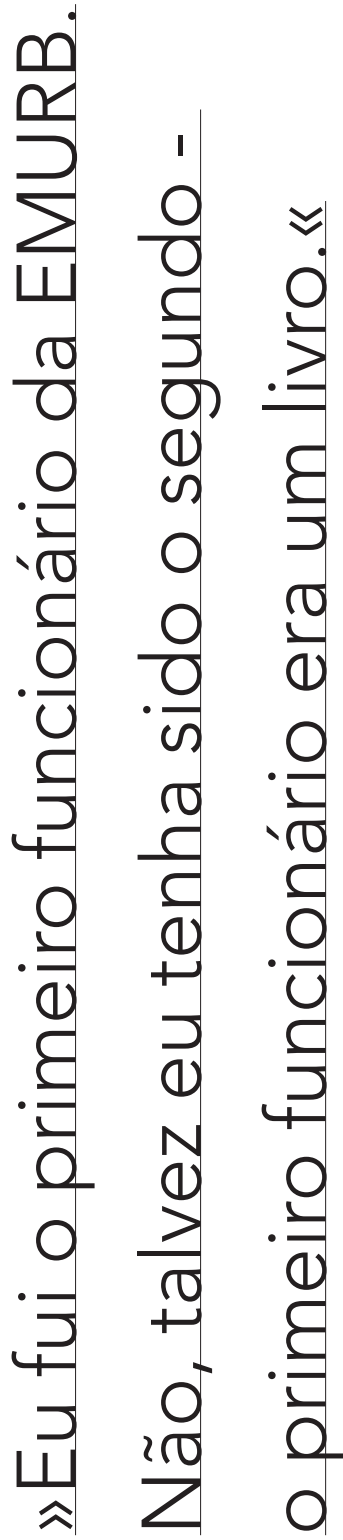


"A tese da CURA era que novos empreendimentos na área iram gerar um refluxo de recurso $e$ impostos, que iam cobrir o gasto da Prefeitura. Mas nunca esse feedback foi feito. Quem vai lá hoje percebe que tem uma transformação muito grande na área por razão da CURA. $\ll^{3}$

3 Entrevista, Clementina Delfina de Ambrosis, Domingos Teodoro de Azevedo Marques e Geraldo Vespaziano Puntoni, 26.05.2014

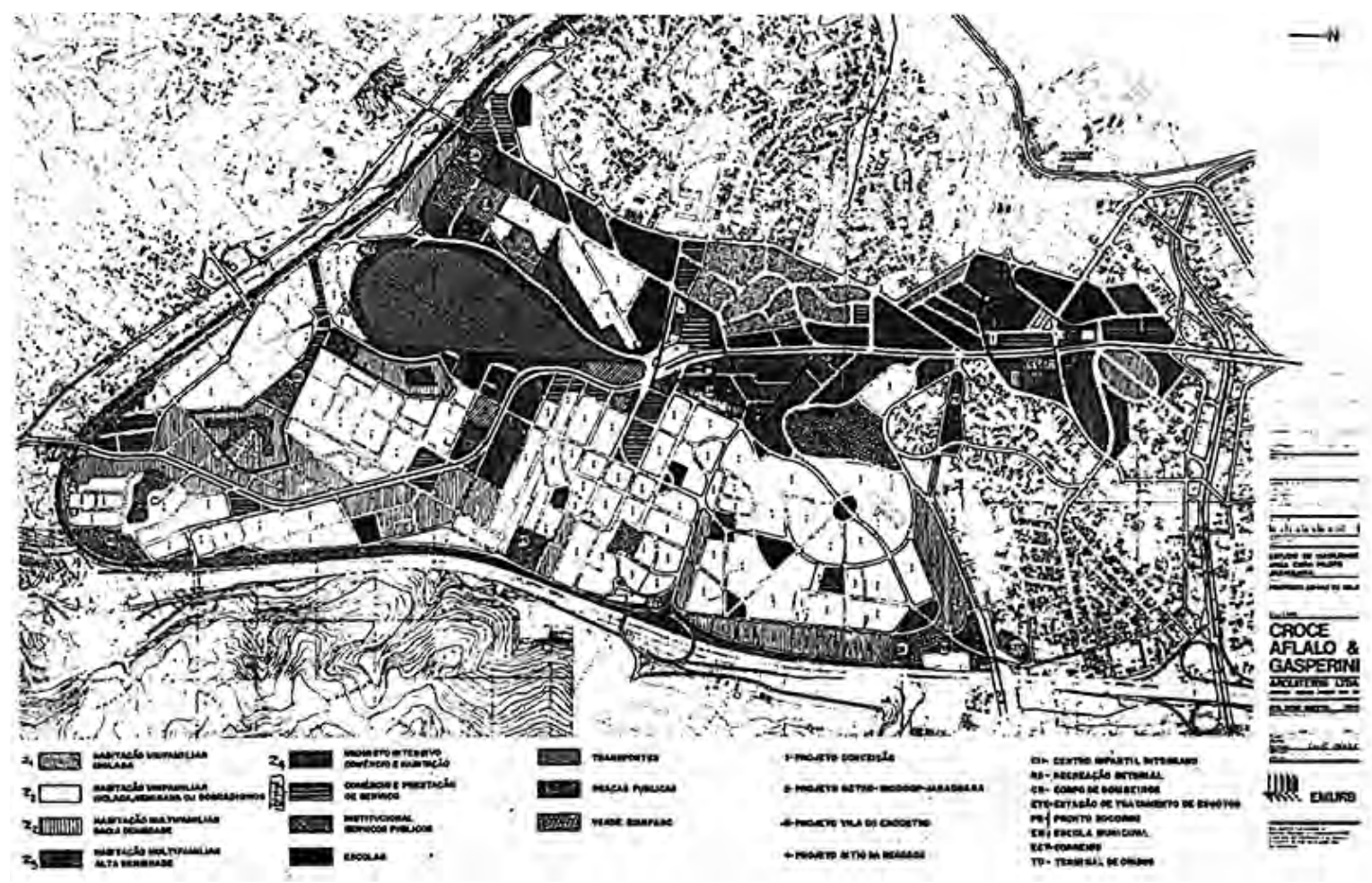

Em 1973, a Prefeitura de São Paulo aderiu ao programa Comunidades Urbanas de Recuperação Acelerada - CURA, do BNH (Lucchese, 2004), que definiu, inicialmente quatro áreas de atuação: Santana, Jabaquara, Vila das Mercês e Itaquera. A EMURB foi a coordenadora do programa CURA e elaborou diretrizes para as áreas escolhidas. Depois de algumas experiências menos sucedidas pelo programa CURA, a Prefeitura escolheu o projeto CURA Jabaquara como prioridade principal. Geraldo Vespaziano Puntoni atuou como coordenador dos estudos da implantação do projeto piloto do CURA em Jabaquara. $\bigcirc$ arquiteto acompanhou os estudos do escritório Croce, Aflalo e Gasperini para a Viabilidade Econômico/Financeira da Área Cura Piloto Jabaquara. A grande área foi divida em quatro perímetros de reurbanização: Área da estação Conceição, áreas próximas da estação Jabaquara, área do Sítio da Ressaca e a área da Vila do Encontro. No extremo sul da linha de Metrô foi implantada a estação Jabaquara, com o objetivo de ligar dois terminais, um de ônibus rodoviários interurbanos e outro 
para ônibus metropolitanos que pretendiam conectar a região do $A B C$.

$» O$ projeto reorganizou completamente o arruamento preexistente e integra por galeria sob a avenida os dois terminais e o mezanino da estação de Metrô ${ }^{4}$

partido arquitetônico dos terminais explora a especialidade por meio de grandes coberturas horizontais, conectando os dois lados do espigão pelo qual passa a avenida. Nas proximidades do projeto intermodal encontram-se diversos conjuntos habitacionais, que foram realizados pelo COHAB e INOCOOP, além de outros investimentos privados. No sul, ao lado do pátio de manobras do Metrô foi projetada uma área onde se localiza o Centro Cultural, prédio que incorpora uma casa tombada de $1712 \mathrm{em}$ sua construção. $O$ restauro da casa foi coordenado pelo EMURB, com o arquiteto Nestor

4 ANELLI, Renato, Plano de Conformação da Base da Metrópole: Redes de Mobilidade Paulistanas, USP São Carlos, Marca Visual, 2011, São Paulo, p.53
IMAGEM 130. Perspectiva do plano de reurbanisazão da poligonal do Sítio da Ressaca (ao lado do pátio de manobras do Mêtro). A verticalização planejada em conjunto com um parque, restauração da casa histórica de 1712 e construção do Centro Cultural. Fonte: EMURB Revista, Reurbanização

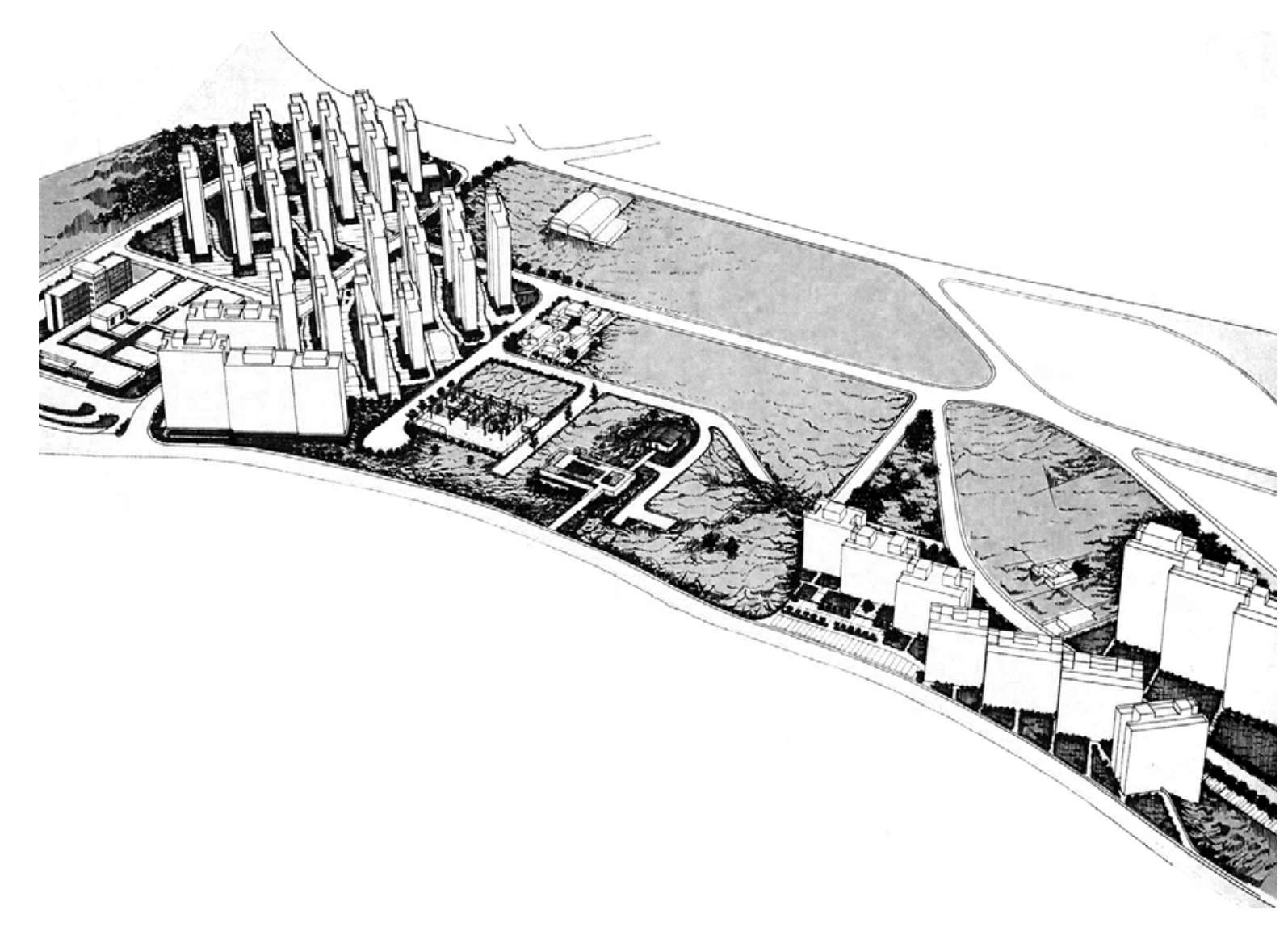



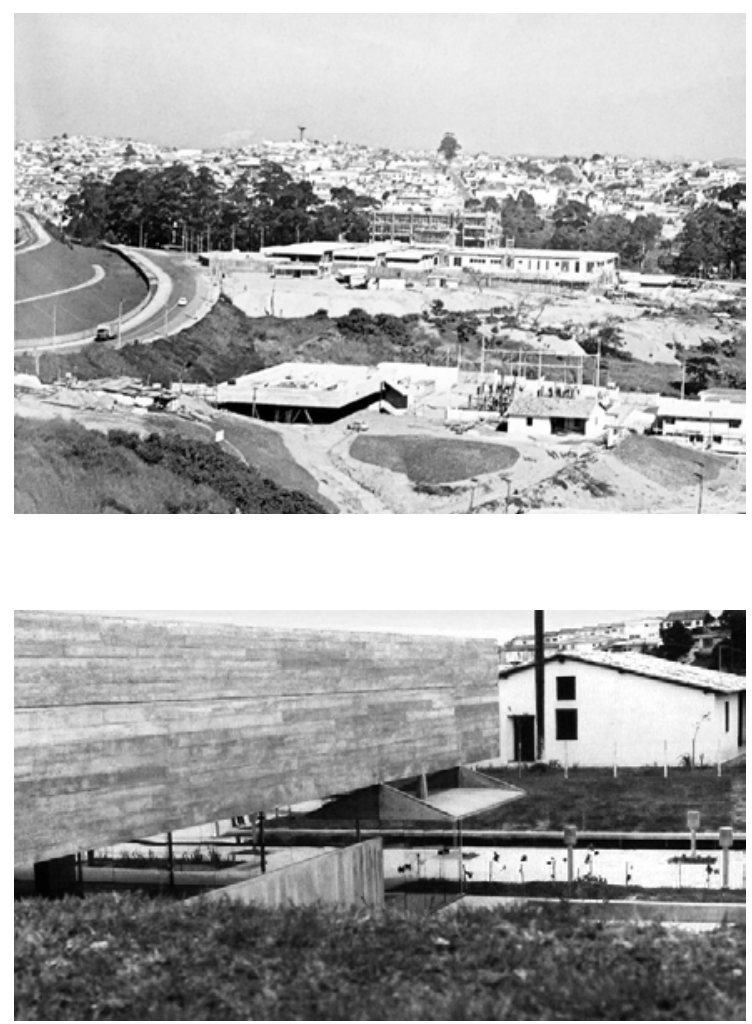

IMAGEM 131. Sítio da Ressaca, Centro Cultural Jabaquara a casa histórica em obra, Fonte: EMURB Revista, Reurbanização

IMAGEM 132. Centro Cultural Jabaquara em primeiro plano; mais ao fundo a casa histórica restaurada, Gustavo Neves da Rocha Filho, Fonte: http:// www.shieh.com.br/CENTRO-CULTURAL-JABAQUARA

176 historiado Goulart Reis Filho como diretor de planejamento. Ao seu redor foi construído um parque com projeto paisagístico de Rosa Klias, local onde também se encontra uma biblioteca, posicionada de modo a passar despercebida diante à da casa tombada. Este exemplo de arquitetura dos equipamentos públicos paulistanos mostra as potencialidades arquitetônicas dos planos da EMURB, no entanto o plano integrado para toda essa área, foi dividido entre várias secretarias da prefeitura, com a influência de outros atores como INOCOOP, COHAB, COGEP, Secretarias Municipais de Vias Públicas e de Serviços e Obras. Ainda que a função do EMURB tenha sido evitar a dispersão das intervenções municipais, os problemas decorrentes de coordenação expõe os limites sociais da política urbana do período; Apesar da área ter um conjunto de bairros periféricos, nos quais predominavam moradores com baixa renda e falta de infraestrutura, os conjuntos habitacionais propostos pela COHAB tinham um perfil de renda média (Lucchese,2004). Os estudos desenvolvidos pouco após a sua implantação demonstraram uma grande valorização da área alterando o perfil social de seus moradores. A mesma coisa ocorreu na área Conceição, situado no norte da intervenção de reurbanização no entanto a área já era mais consolidada do que os trechos da porção sul. No projeto foi previsto a reestruturação do sistema viário, uma praça aliada a da estação de metrô, um parque para aproveitar a mata existente, um terminal de ônibus e seis grande áreas para empreendimentos comerciais. Somente em 1981 foi iniciada a revisão do plano urbanístico, ou seja a realização do empreendimento levou mais tempo do que o esperado. A unificação das quatro áreas, propostas no plano inicial, possibilitou uma nova estrutura do espaço comum A interligação subterrânea entre os edifícios permitiu a liberação do solo para a continuidade da superfície e criou uma experiência bem sucedida de novos padrões de urbanização. A experiência de Jabaquara cumpriu com seu objetivo original, criando adensamento através da verticalização ao longo das novas linhas de Metrô e promovendo corredores de atividades 
múltiplas. $\bigcirc$ projeto conseguiu transformar uma área de baixo custo imobiliário em uma área de grande concentração populacional, servida por modernos sistemas de transporte de mas-

sa. Entretanto deve ser considerado, segundo Renato Anelli:

" [...] que a estratégia de conquistar para o poder público o retorno financeiro dos seus investimentos no Metrô descarta o desenvolvimento de uma politica social associado à melhoria no sistema de transporte. $\ll^{5}$

A principal preocupação do programa CURA era a construção de moradias sociais nas áreas de investimento público, algo que não era prioridade para os gestores municipais (Lucchese, 2004). Mesmo assim, a crítica não pôde impedir a introdução de novas propostas urbanísticas e arquitetônicas para a escala metropolitana. $\bigcirc$ complexo intermodal junto à estação Jabaquara e a reurbanização das outras áreas

5 Idem. p. 56 ligadas a estação Conceição apresentaram caraterísticas distintas, mas ambos referem-se às condições de uma rede em macro escala, muito mais do que à situação preexistente. Baseado nisso, ainda que poucos dos propósitos foram de fato realizados, a EMURB contribuiu com novas concepções, que relacionam diretamente as maiores densidades urbanas com as linhas de transportes rápido de massa, para a concretização adequada de uma cidade do porte de São Paulo.

\section{PROJETOS DE REABILITAÇÃO} NA REGIÃO CENTRAL DE SÃO PAULO

As discussões sobre intervenções urbanas do poder público em áreas centrais é, provavelmente, um dos temas mais polêmicos entre arquitetos e urbanistas. As cidades estão em transformação contínua, visto como um mecanismo socialmente construído. A decadência ou o afloramento dos centros dependem das mudanças da sociedade na qual ela se insere. Dependendo de como o Estado atua sobre a 
produção do espaço podem ocorrer desenvolvimentos e novos investimentos pelo mercado, mas o término dessas atividades pelo poder público tem por consequência o declínio econômico e a migração. Como resposta a esses processos, o poder público vêm desenvolvendo políticas urbanas de intervenção para áreas centrais com risco de degradação. Existem basicamente duas maneiras: a primeira seria sua erradicação, provocada pela renovação do ambiente construído; a segunda, praticamente o que foi feito nos anos 70 no centro de São Paulo, seria sua reabilitação, com projetos de melhorias. (Nobre, 2009)

Entre 1975 e 1979, durante a atuação de Geraldo Vespaziano Puntoni na EMURB, os planos da prefeitura para o centro tiveram grande ênfase nas questões do patrimônio histórico e do tráfego de veículos, baseados na idéia de reabilitação do ambiente urbano. Esses planos resultaram na desapropriação e restauro do Edifício Martinelli, um dos principais marcos simbólicos paulistanos. A segunda grande iniciati- va do poder público nessa época foi a criação de um sistema de circulação para pedestres na área central, com a construção de $41.300 \mathrm{~m}^{2}$ de calçadões. A terceira intervenção da época é o restauro do Viaduto Santa Ifigênia. $O$ viaduto foi inaugurado em 1913 pelo prefeito Raymundo Duprat. Para a execução da obra, foram importadas 1.100 toneladas de ferro da Bélgica. A lista de obras é maior, entre a reestruturação do Edifício Martinelli, da construção dos calçadões e do restauro do Viaduto Santa Ifigênia destacam-se a revitalização do Palácio das Indústrias, a reurbanização do Vale do Anhangabaú, Praça da Sé, Praça Roosevelt e Pátio do Colégio.

\section{UM EDIFÍCIO}

O prédio Martinelli leva o nome de seu idealizador e construtor, o comerciante italiano Giuseppe Martinelli. Desde sua construção na década de 20, o edifício foi motivo de orgulho para os paulistas: $\bigcirc$ prédio mais alto da América Latina e o maior do mundo em estrutura de concreto armado. Quando inaugurado em 1934, o prédio 
tinha 27 andares, 1.180 salas e apartamentos e 105 metros de altura. Sua silhueta vertical dominou a paisagem urbana do centro, na colina onde nasceu a cidade. Como centro das atividades sociais da elite paulistana, abrigava, além de escritórios, cinema, hotel, restaurante, cassino, clubes noturnos, salões de festas, clubes e associações. Os acabamentos eram luxuosos: piso e escada feitos em mármore Carrara, portas em pinho de Riga, e ferragens inglesas. Mas, apesar de todos os requintes seu esplendor foi efêmero, pois a partir de 1940, durante a Segunda Grande Guerra, diversas circunstâncias provocaram sua decadência e posterior deterioração. Na década de 60 o prédio transformou-se em um imenso cortiço vertical - chegando a abrigar cerca de 4.000 residentes, tornando-se um reduto de marginais e foco de criminalidade, refletindo negativamente a qualidade de vida do centro tradicional de São Paulo. $O$ estado de deterioração do edifício era tal, que era possível encontrar vazamentos, infiltrações,

IMAGEM 133. Perspectiva Centro histórico São Paulo com o Edifício Martinelli, Fonte: Revista, EMURB

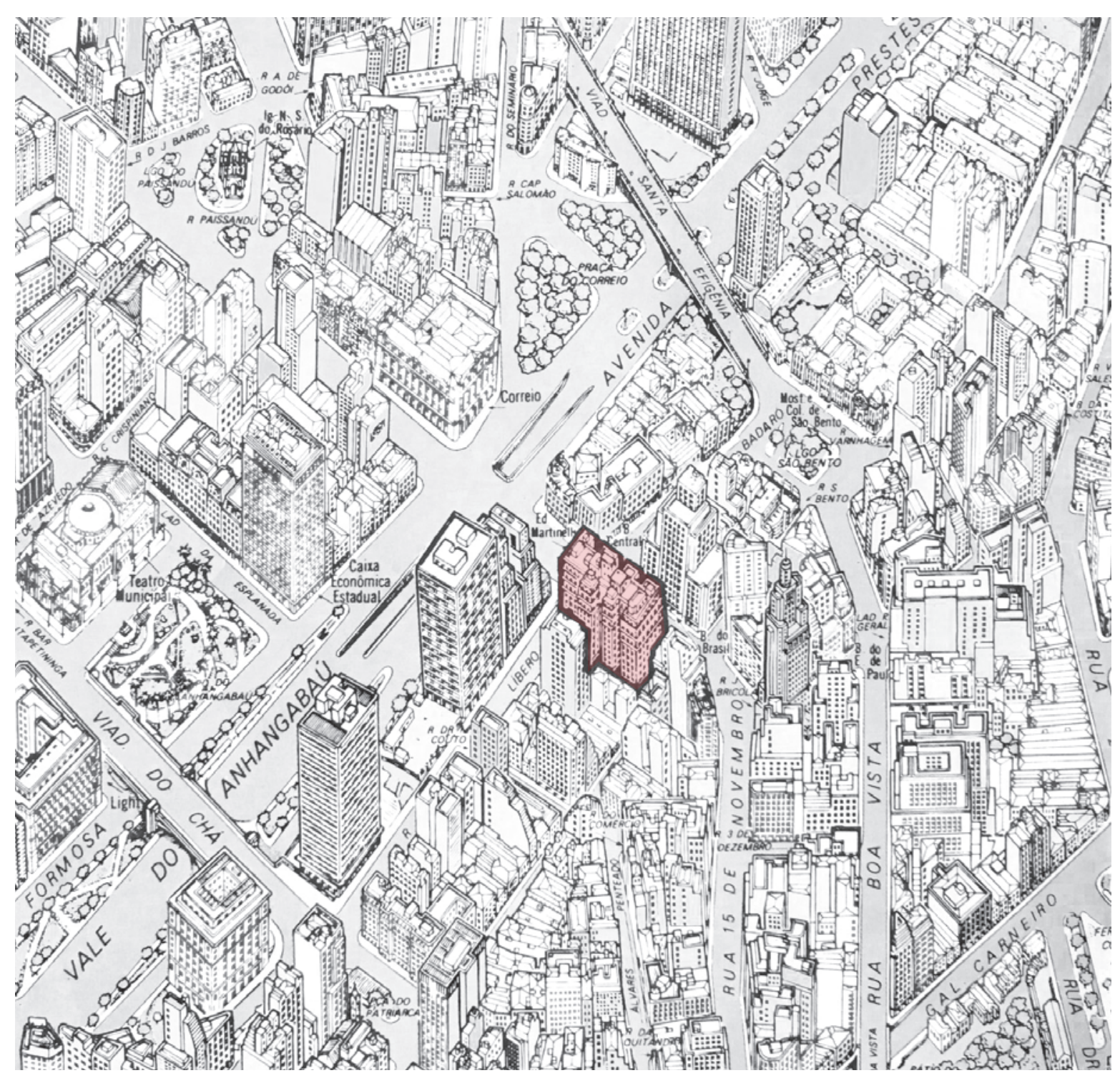



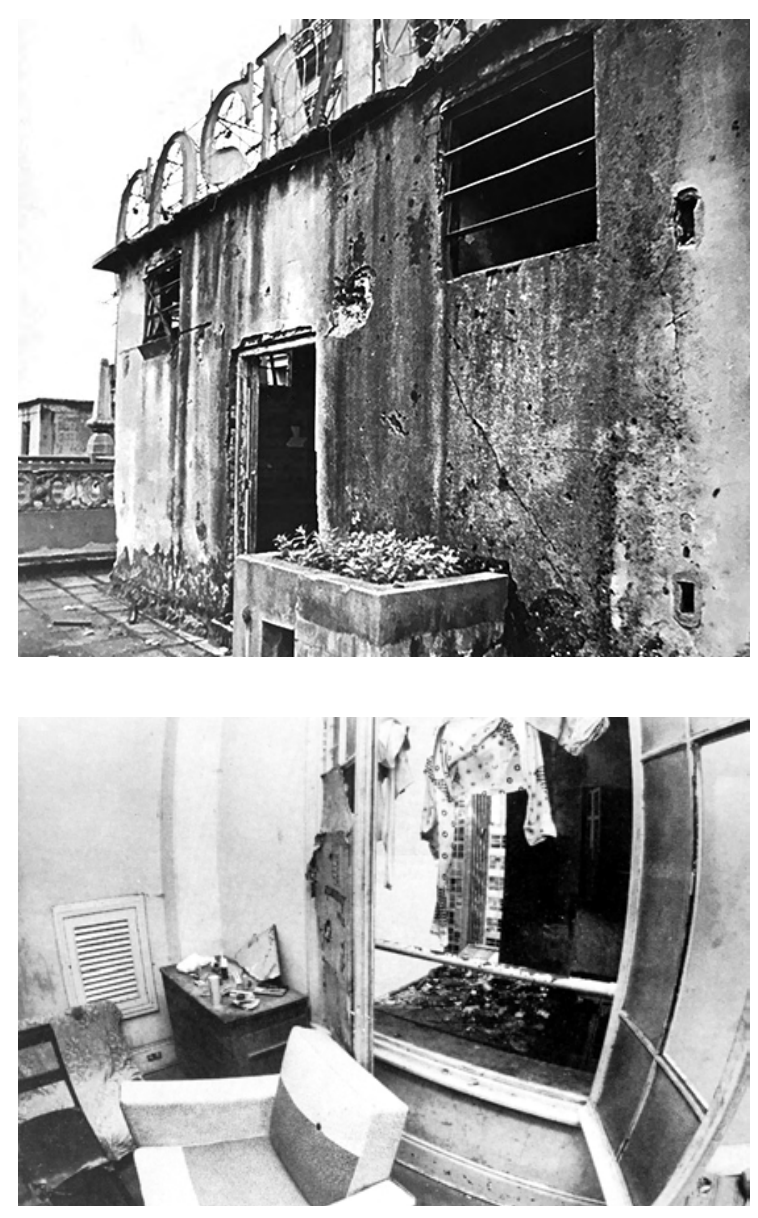

IMAGEM 134. Terraço, estado de deterioração antes da intervencão, 1975 , Fonte: EMURB, Revista.

IMAGEM 135. Apartamento, estado de deterioração antes da intervenção, 1975, Fonte: EMURB, Revista.

180 lixo atulhado nos pátios internos e elevadores quebrados; muitos banheiros tornaram-se coletivos e até apartamentos pequenos eram subdivididos. A necessidade de uma intervenção oficial por algum órgão público era mais do que necessária, mas ainda faltavam instrumentos e experiência para agir num edifício de 50.000 $\mathrm{m}^{2}$, com mais de uma centena de proprietários e outros tantos locatários, sem limites precisos entre as áreas comuns e as áreas privativas.

»A reforma do Martinelli foi muito interessante. A grande peça da reforma é o projeto jurídico, o edifício era propriedade de deus e de todo mundo. O advogado Sampaio Mesquita, conseguiu o projeto jurídico para poder demolir as divisórias e os apartamentos antigos. $\|^{6}$

A Lei Municipal n. ${ }^{\circ} 8.255$, de 26 de maio de 1975, promulgado pelo Prefeito Olavo Setúbal, permitiu a intervenção da EMURB no edi-

6 Entrevista, Geraldo Vespaziano Puntoni, Marlene Picarelli, Lúcio Grinover, 04.07.2016 fício, considerando o projeto como uma obra de reurbanização. Foram necessários meses para a evacuação completa do edifício, devido as negociações com os proprietários, os acordos e as expropriações. Ao mesmo tempo, foram desenvolvidos os estudos de modo a manter as caraterísticas externas do edifício, mas modernizando seu interior a fim de assegurar as condições de »salubridade pública, higiene, segurança e uso, funcionalidade e habitabilidade« conforme os termos da lei específica citada. As obras foram iniciadas em 1977 com a desinfecção e a retirada de centenas de caminhões de lixo que estava acumulado no prédio. Antes da obra principal vários outros trabalhos foram executados: proteções externas para permitir o funcionamento das lojas, garantir a segurança dos pedestres que circulavam nas três vias circundantes, o acesso de materiais de obra, etc. Quem coordenou a obra foi o engenheiro Bolivar Pereira da Silva: 
»A gente fazia a obra das 10:00hs da noite até as 6:00hs da manha, isso foi uma grande vantagem, pois ninguém atrapalhava ninguém. Todo mundo só trabalhando. « ${ }^{7}$

Foi feita a desmontagem, limpeza e recuperação das esquadrias de madeira e de ferro, e finalmente a sua recolocação nos locais originais. Também foram realizadas pesquisas relativas a estrutura e aos vários materiais aplicados. As fachadas deformadas foram reconstituídas através da restauração de suas marquises, como também a limpeza dos revestimentos externos. Os interiores foram inteiramente reformados e restaurados. A planta ao lado demonstra a quantidade de paredes que foram demolidas. Segundo Vespaziano Puntoni:

»Foram tiradas quase todas as paredes do interior, os andares transformaram-se, praticamente, em uma »planta livre«. $\ll^{8}$

7 Entrevista Geraldo Vespaziano Puntoni e Bolivar Pereira da Silva, 16.06 .2015

8 Idem.

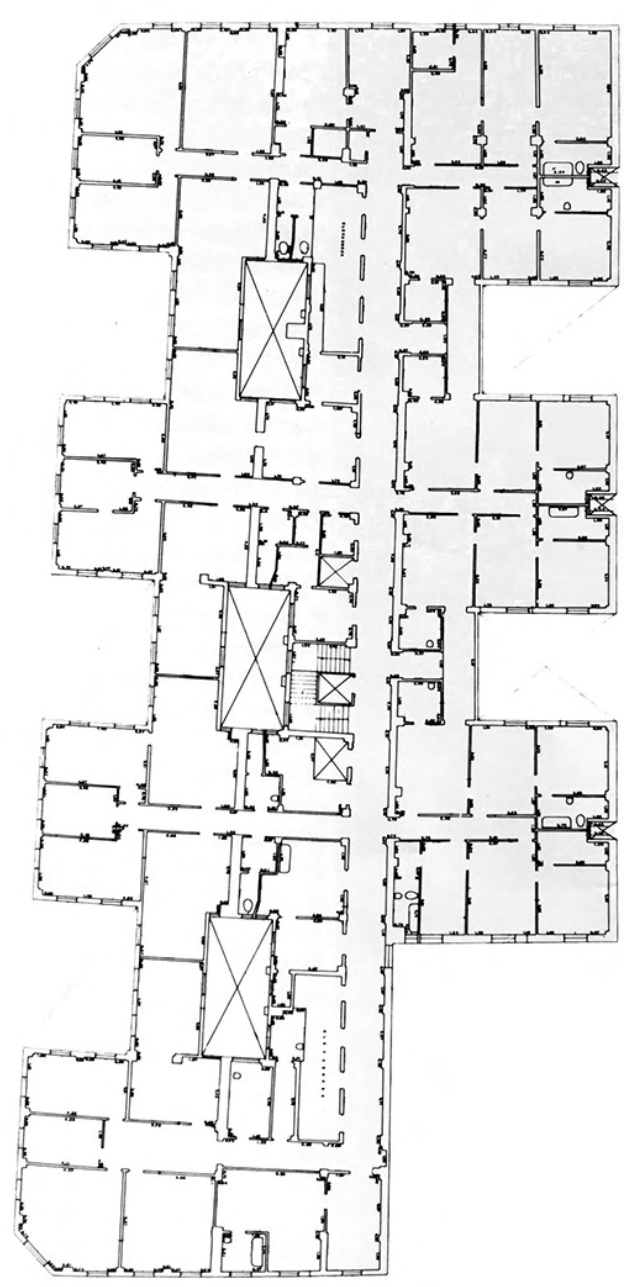

IMAGEM 136. Andar Típo, andares da intervenção, Fonte: Revista, EMURB

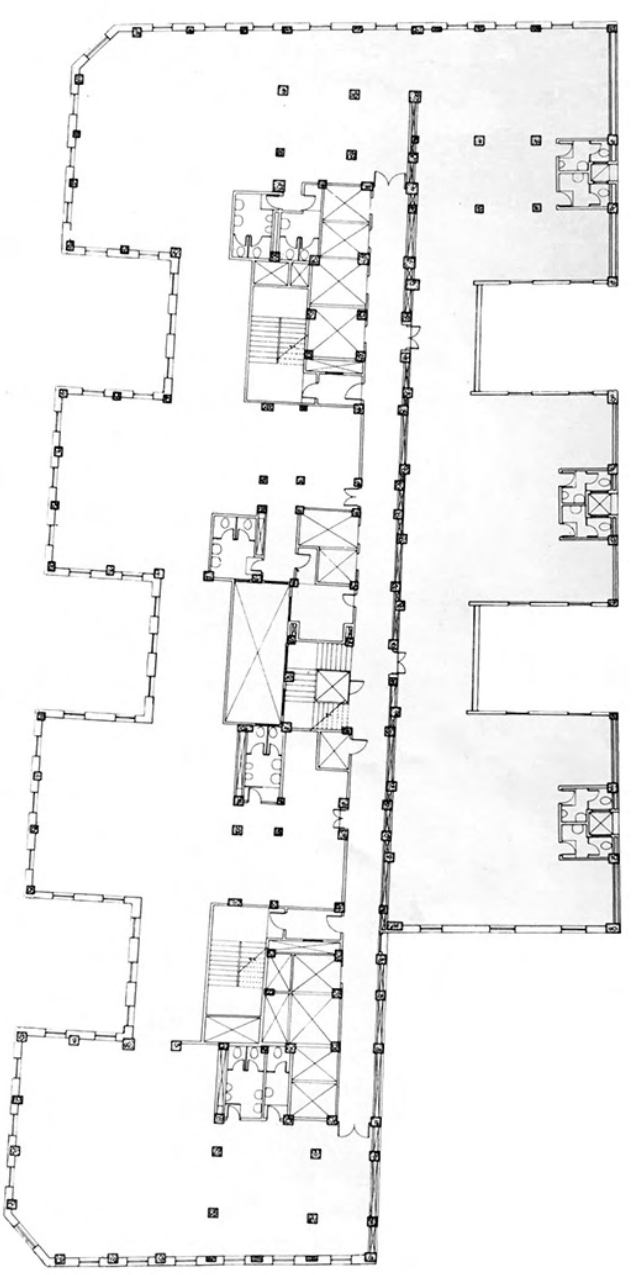

IMAGEM 137. Andar Típo, após a reforma, Fonte: Revista, EMURB 


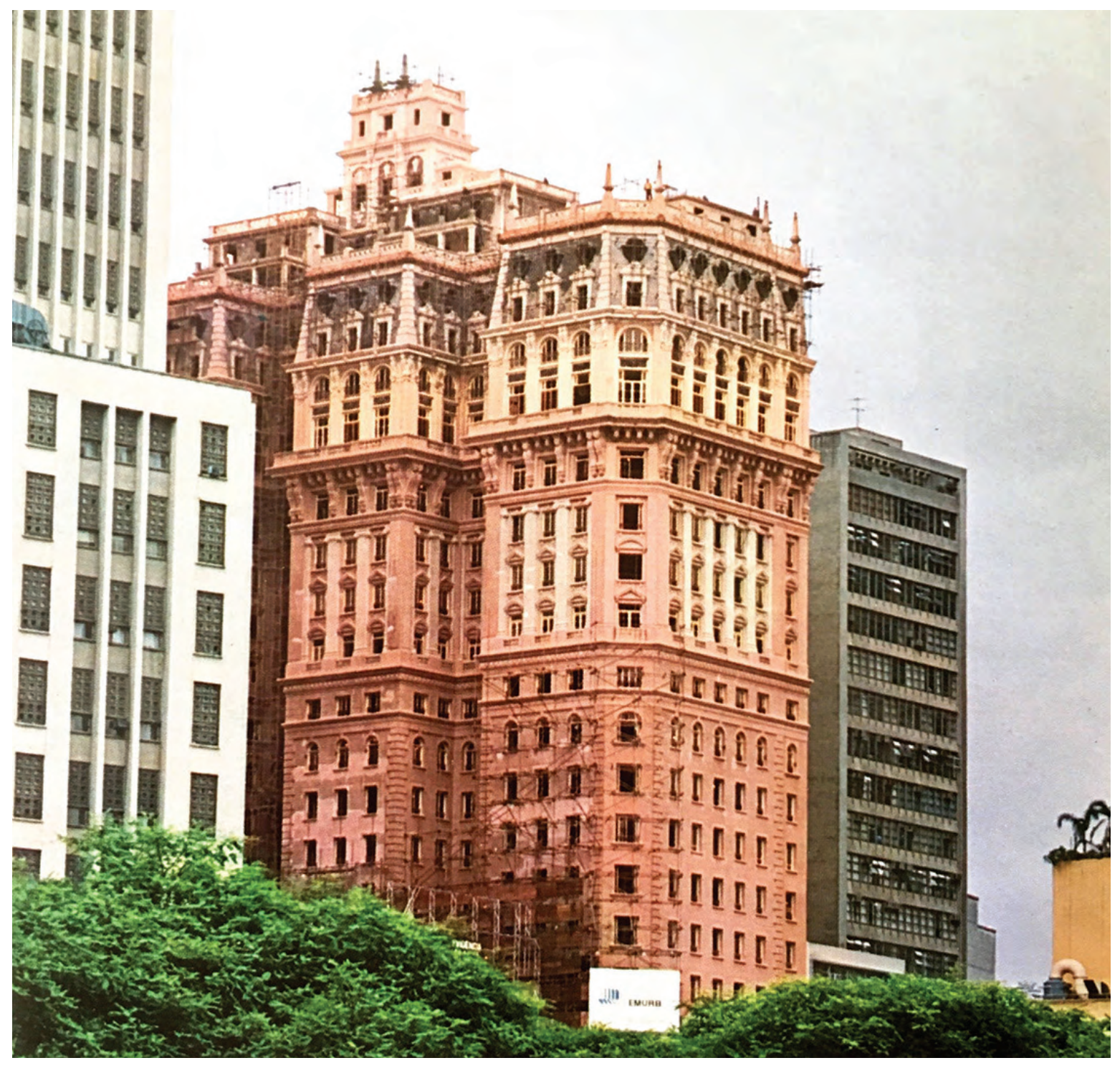

182
As áreas comuns foram redimensionadas, equipamentos de segurança e de combate a incêndio foram instalados. O sistema hidráulico foi completamente reconstruído, inclusive a captação e as prumadas de águas pluviais, além de uma nova rede de esgoto. $O$ edifício contou com novas instalações elétricas, redes de gás e telefones. Além do restauro da escada principal, mais duas escadas de segurança, dotadas de antecâmaras e dutos de ventilação, garantiram a nova segurança em caso de incêndio. Para seu funcionamento diário, o edifício Martinelli foi equipado com doze novos elevadores. Um sistema de circulação garantiu o atendimento e funcionamento racional. É importante ressaltar o fato de que apesar de todos as reformas, o edifício não perdeu suas caraterísticas originais, seus incontáveis adornos e até o tradicional corde-rosa de suas paredes externas foram mantidos. A obra foi concluída em março de 1979.

IMAGEM 138. Fachada Prédio Martinelli, após da reforma, 1977 Fonte: EMURB, Revista. 


\section{UM VIADUTO}

Originalmente inaugurado em 1913, a obra do Viaduto Santa Ifigênia teve seu início em 1910 O objetivo da ligação entre os largos Santa Ifigênia e São Bento era facilitar o tráfego pela Rua São João. Com o passar dos anos, ápos décadas de falta de conservação e crescente poluição atmosférica, o Viaduto Santa Ifigênia acabou se deteriorando. Diversas possibilidades foram discutidas na época: Reconstruir, demolir ou recuperar. Finalmente, a EMURB solicitou ao IPT - Instituto de Pesquisa Tecnológicas de São Paulo S.A. - uma verificação técnica do comportamento estrutural do Viaduto. De acordo com o laudo pericial entregue à empresa, o viaduto estava em plenas condições de uso, desde que efetuada a sua recuperação e substituição das peças danificadas.

IMAGEM 139. Perspectiva Centro histórico São Paulo com Viaduto Santa Ifigênia, Fonte: Revista, EMURB

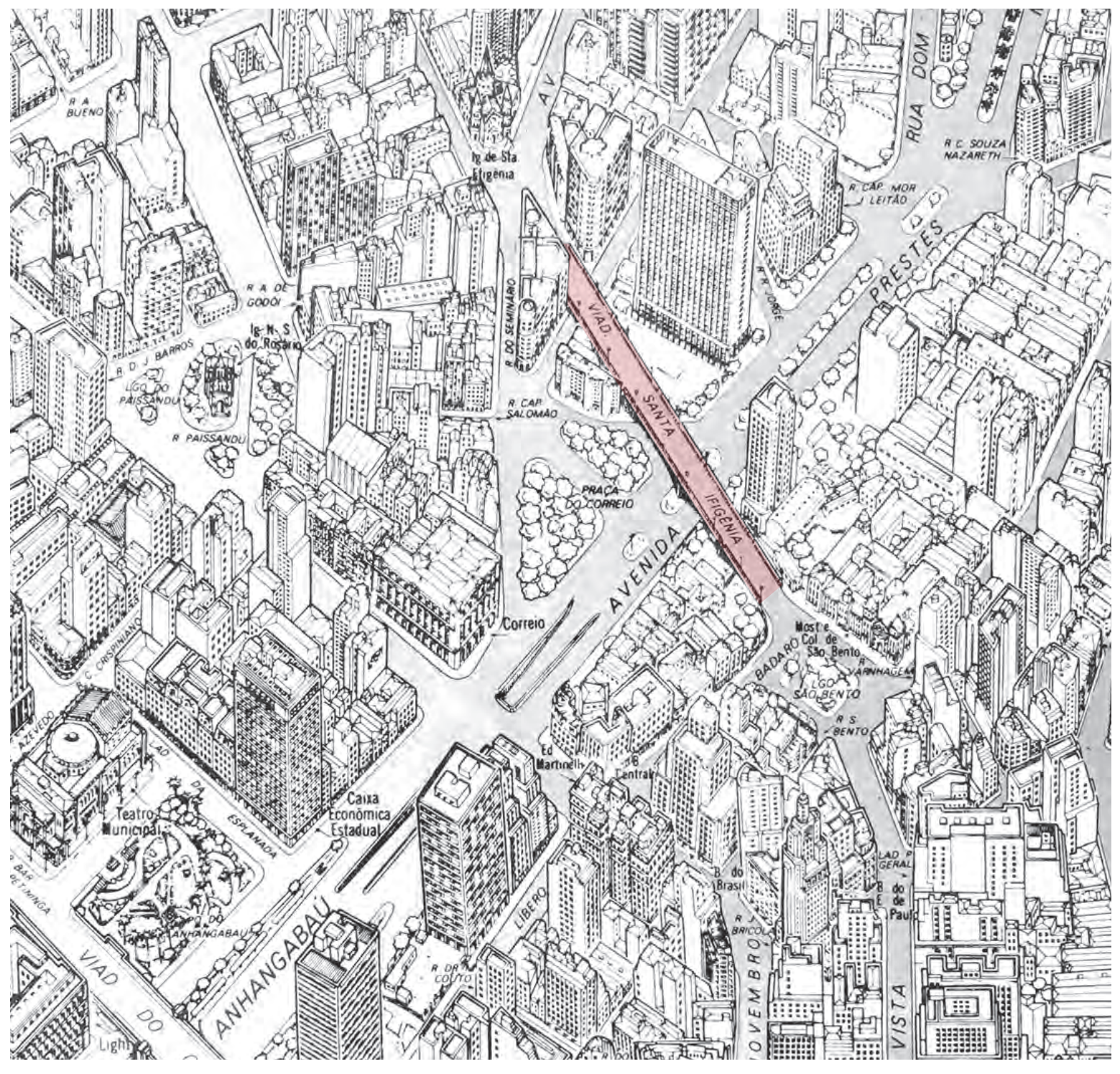




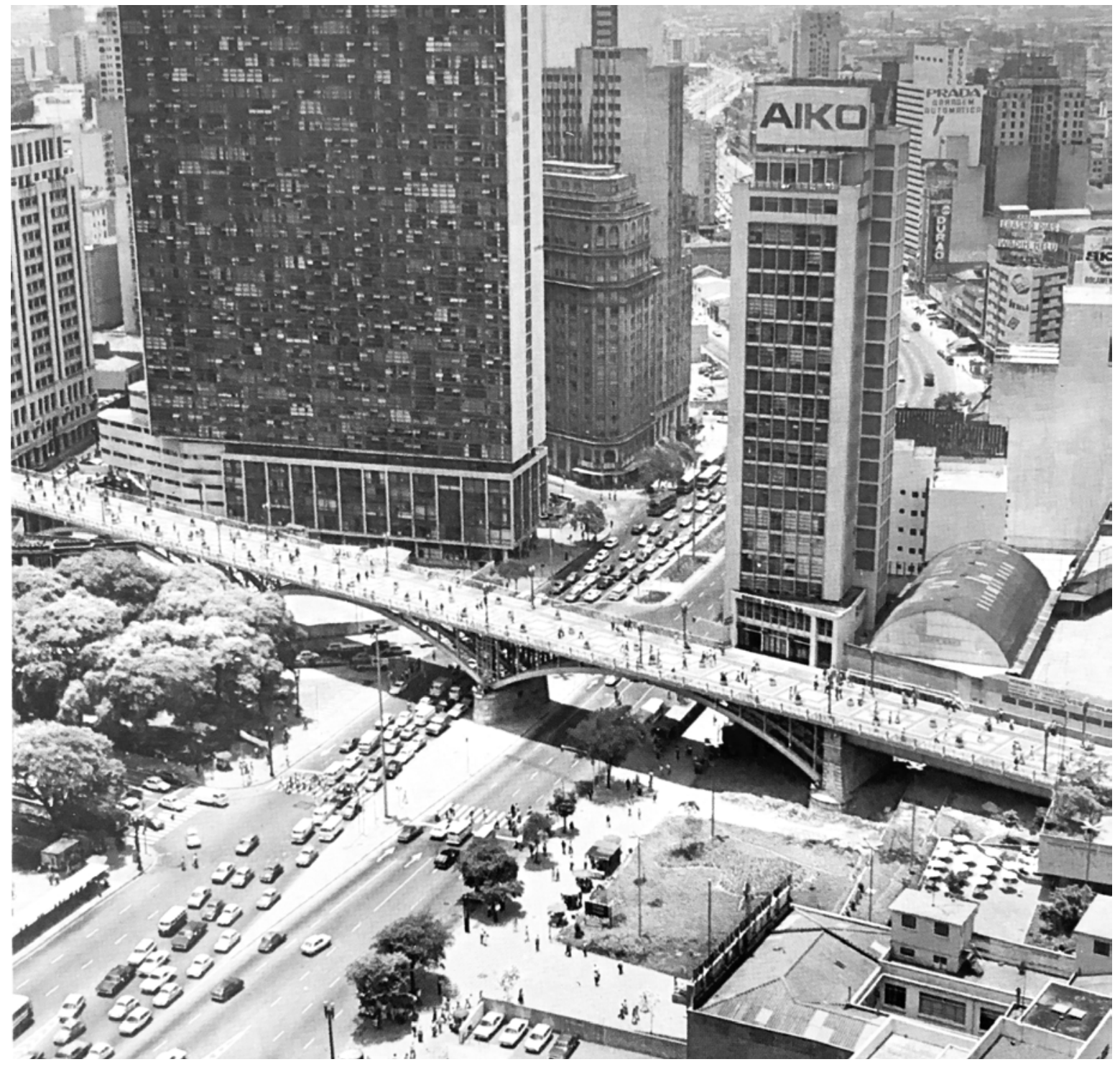

184
Depois dez meses de obras o viaduto foi entregue novamente à população em 1978. A recuperação do Viaduto Santa Ifigênia no Vale do Anhangabaú foi mais um elemento significativo, que contribuiu para a reabilitação do centro histórico de São Paulo, através da atuação da EMURB. A estrutura do viaduto foi completamente descoberta em seus 225 metros de comprimento e 15,30 metros de largura, com a intenção de diminuir a interferência que a obra causa na vida da cidade. Uma estrutura complementar foi montada junto de toda a parte metálica do viaduto, fazendo referência às estruturas usadas em oficinas Foram trocadas cerca de 140 toneladas de peças da estrutura metálica, que foram corroídas pela chuva e pelo sol. A substituição de peças preservou o desenho original do viaduto e exigiu quase uma produção artesanal das novas peças.

Sua estrutura metálica, de 1.100 toneladas, recebeu uma nova pintura em cor ocre, mas an-

IMAGEM 140. Viaduto Santa Ifigênia, Vista superior, 1978, Fonte: Arquivo, EMURB 
tes passou por um processo de limpeza com lixas, espátulas e jatos de areia. A parte superior do viaduto também passou por um tratamento especial: o piso composto por $3.450 \mathrm{~m}^{2}$ de pastilhas pretas, brancas e cor de cerâmica, adequado à referência visual do pedestre, amenizando a passagem sobre o vale. Como parte da recuperação superior, a EMURB trocou as rosáceas corroídas das balaustradas por novas peças forjadas em seu estilo original. Quanto ao mobiliário urbano, foram dispostas cerca de 100 floreiras sobre o tabuleiro, juntamente com 22 postes ornamentais com o desenho tradicional do centro da cidade. Nos extremos do viaduto as floreiras bloqueiam a entrada de carros, uma vez que um dos partidos da reabilitação do viaduto foi a retirada de veículos. A ponte foi transformada em uma travessia de pedestres, seguindo o mesmo conceito dos novos calçadões, construidos entre 1976 e 1978, no centro da cidade de São Paulo. Com a construção de uma escada de 12 metros de altura na área da
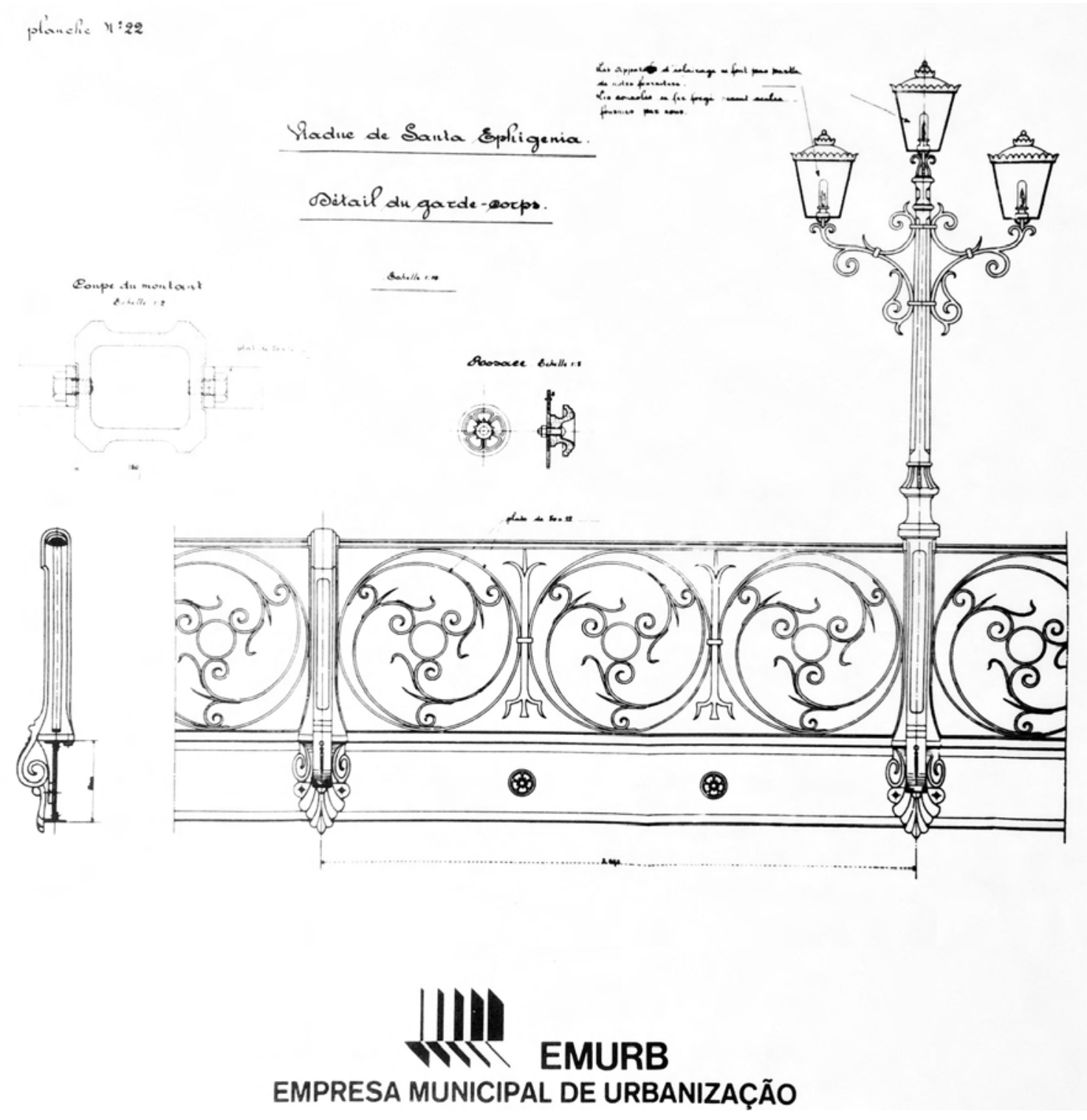
praça próximo à Rua Brigadeiro Tobias, a intervenção previa a conexão entre o viaduto e

o Vale do Anhangabaú. Essa intenção ganhou mais força a partir do projeto do Vale, desen-

volvido pelo arquiteto Jorge Wilheim em 1981.

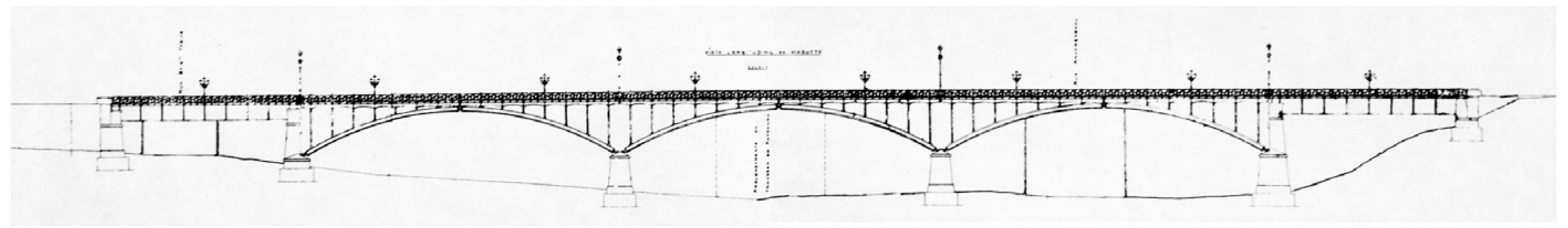

IMAGEM 142. Viaduto Santa Ifigênia, Elevação, Original, 1906. Fonte: Arquivo Vivo o Centro, São Paulo. 


\section{UMA RUA DE PEDESTRES}

Durante a administração do Prefeito Olavo Setúbal (1975-1979), a preocupação com os pedestres passou a ser uma constante por conta de diversos fatores, como o início do funcionamento do Metrô, a prioridade concedida ao transporte público e, provavelmente, alguns exemplos encontrados em diversas cidades no mundo. Mesmo assim, o objetivo principal era valorizar o centro da cidade, suas atividades e seu comércio. Passavam diariamente pelas ruas centrais centenas de milhares de carros e ônibus ameaçando a integridade física do pedestre, que caminhava espremido nas calçadas. Com a iniciativa do órgão público EMURB, as ruas transformaram-se entre 1976 e 1978 em ruas de pedestres.

O piso das ruas de pedestres foi formado por placas de granito e mosaico português, cuja composição trouxe como virtude a possibilidade de

IMAGEM 143. Rua no Centro Histórico antes da intervenção. Fonte: Arquivo, EMURB

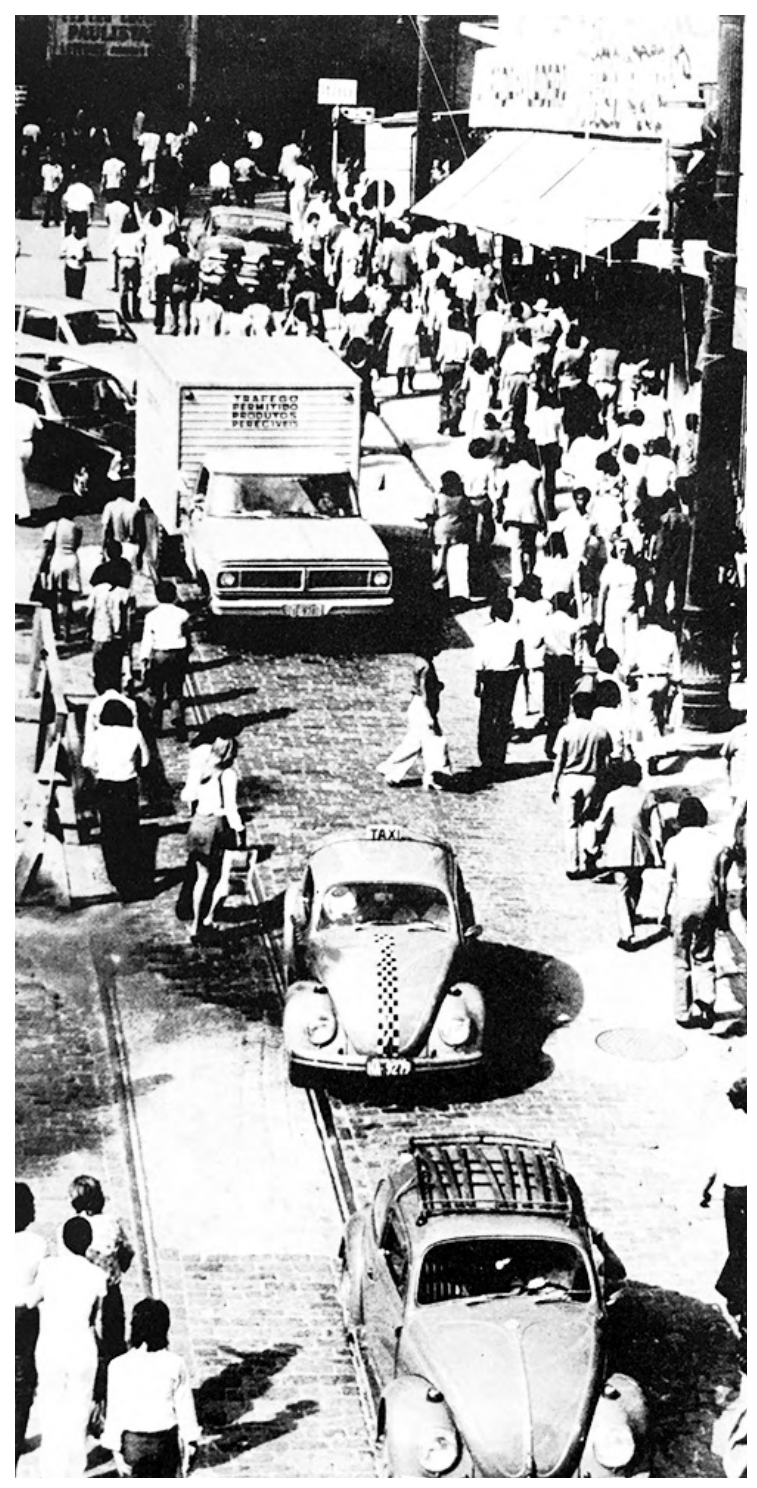


poder ser incorporado sobre qualquer irregularidade do solo. $\bigcirc$ novo desenho tentou incorporar de forma sutil as sarjetas e bueiros através de materiais resistentes, capazes de suportarem o tráfego eventual de veículos de emergência e dos caminhões de abastecimento da área.

\section{Centro Novo}

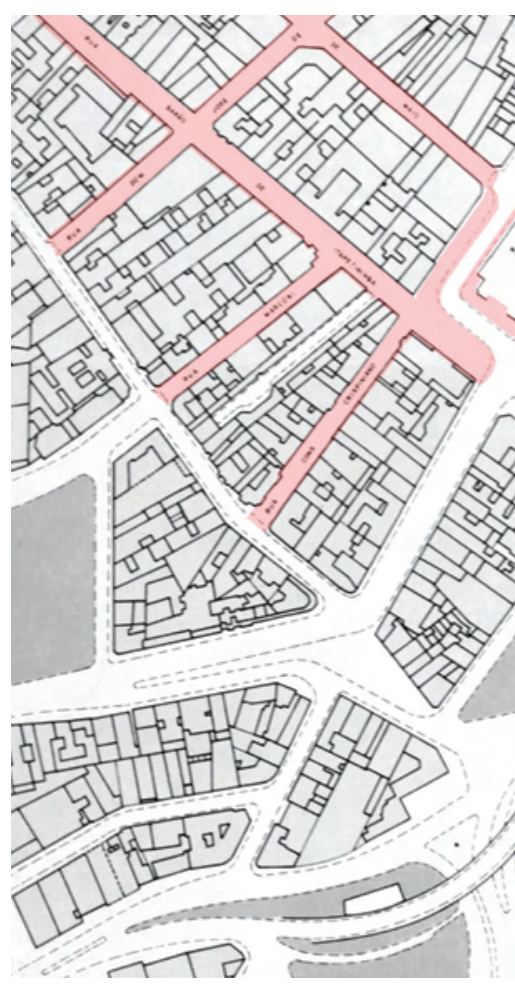

188
Centro Histórico

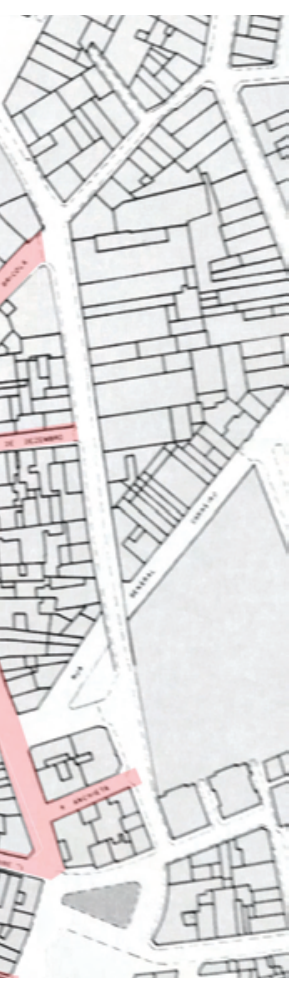

A tradicional Rua São Bento, na área histórica da cidade, foi a primeira a receber o tratamento urbanístico projetado pela EMURB, seguida das ruas Direita, José Bonifácio, Quintino Bocaiúva, Miguel Couto, Senador Paulo Egydio, Tesouro, Álvares Penteado, Quitanda e os largos do Ouvidor, do Café e da Misericórdia. No chamado centro novo, a rua Barão de Itapetininga, D. José de Barros, 24 de Maio e Marconi foram alteradas para as funções de ponto de encontro e local de lazer dos paulistanos. Em 1978, a EMURB completou seu programa de ruas de pedestres no centro, incluindo também as ruas XV de Novembro, João Brícola, Três de Dezembro, Praça Antônio Prado e Aveni-

IMAGEM 144. Planta de Situação Centro Novo - Centro Antigo, Ruas de Pedestres, 1976 - 1978, Fonte: Arquivo, EMURB 
da São João, elevando para $60.000 \mathrm{~m}^{2}$ a área reservada à utilização exclusiva de pedestres.

As ruas de pedestres não foram projetadas apenas como vias onde a circulação de veículos era proibida. As características físicas das ruas também foram alteradas de forma a serem adequadas ao uso do homem. Além de eliminar a faixa dos carros e implementar uma pavimentação adequada, era necessário proporcionar uma nova iluminação, bancos, floreiras, caixas de correio, lixeiras e orelhões.

Segundo Vespaziano Puntoni, um desafio para a administração pública municipal na intervenção era o remanejo da canalização e das redes das concessionárias dos serviços públicos. Com a implantação de $41.300 \mathrm{~m}^{2}$ de ruas de pedestres, a partir de fevereiro de 1976, foi eliminado o acúmulo de águas pluviais no antigo leito carroçável após as chuvas. Nas ruas foram construídos mais de 6.000 metros de canaletas de águas pluviais. Toda água coletada nos edifícios foi drenada diretamente para as galerias abertas
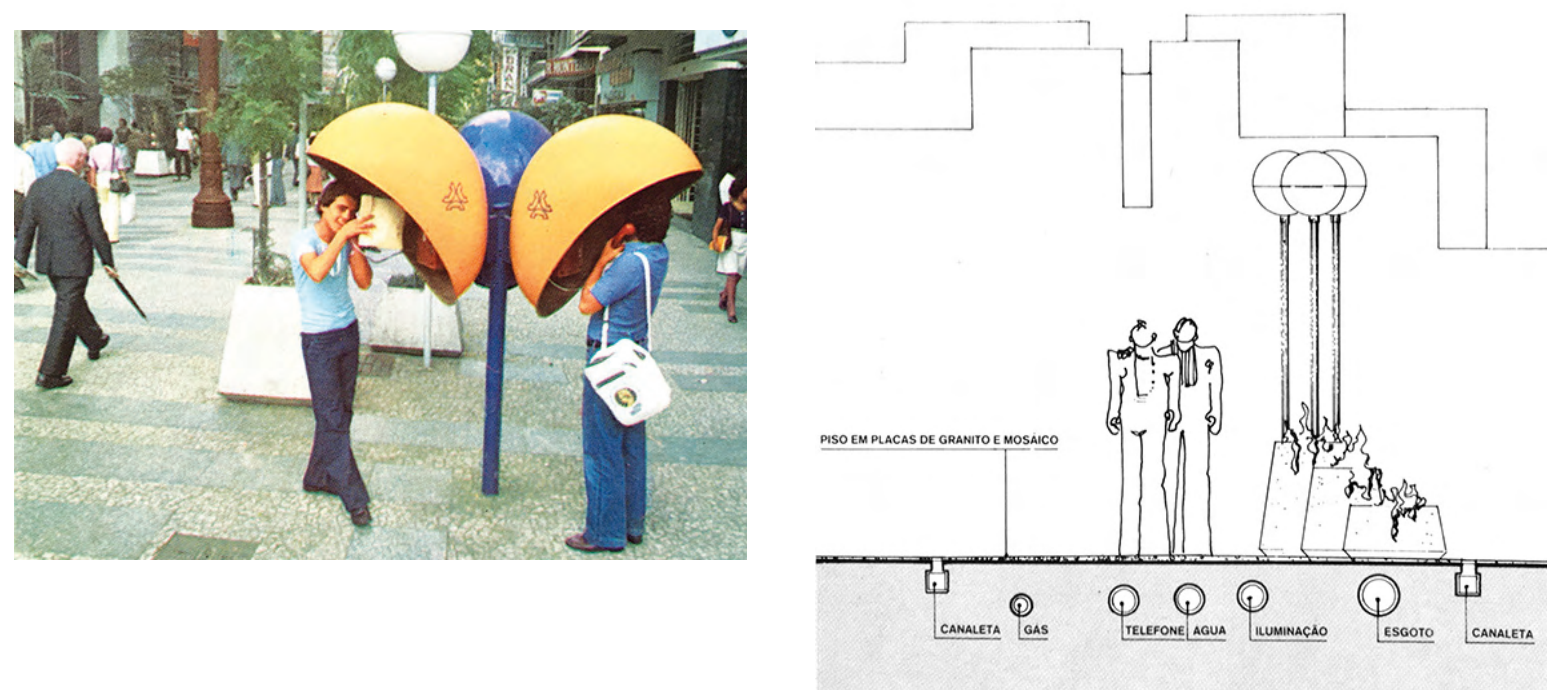

IMAGEM 146. Rua de Pedestres, Centro Histórico após da intervencão. Fonte: Arquivo, Viva o Centro
IMAGEM 145. Rua de Pedestres, Corte Tipo Infraestrutura. Fonte: Arquivo, Viva o Centro 


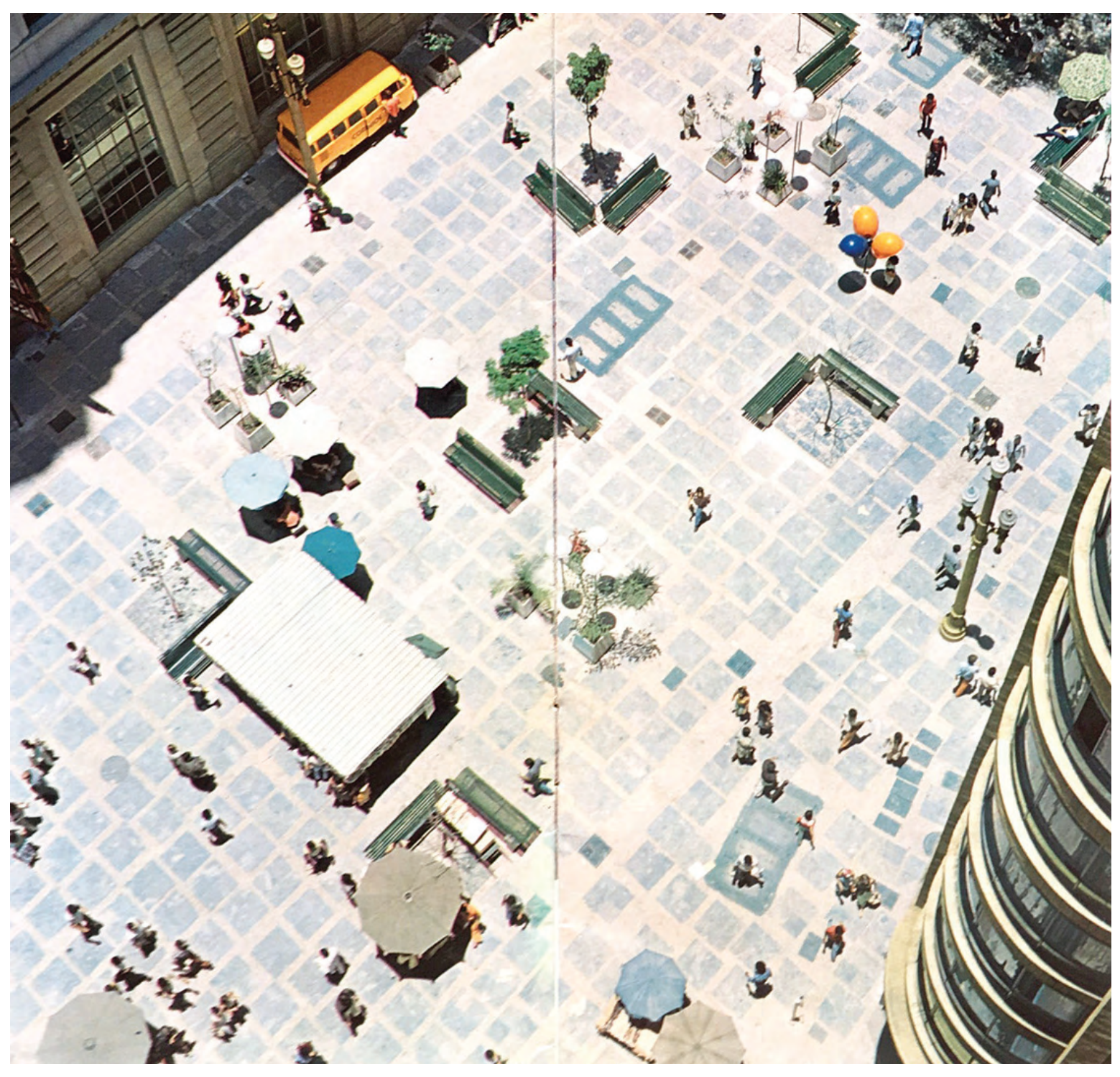

no subsolo. Essa intervenção na região central propiciou às concessionárias de serviços públicos (Light, Telesp, Comgás e Sabesp) a oportunidade de promover o remanejamento e a substituição de muitas de suas canalizações, além da ampliação de suas redes e caixas subterrâneas.

A EMURB utilizou uma estratégia de trabalho compatível com a importância da área, afim de não prejudicar o seu intenso comércio e minimizar os transtornos à considerável parcela da população que por lá circulava. Como no restauro do Edifício Martinelli, as obras foram executadas durante a noite, e tinham os trechos em obras cobertos durante o dia, porém permitindo a passagem normal dos pedestres.

Interessante observar como o projeto das ruas de pedestres no centro de São Paulo encorajou sua implantação nos grandes centros de bairros tradicionais, onde estavam surgindo problemas semelhantes aos da área central. Em Santo IMAGEM 147. Rua de Pedestres, Centro Histórico após da intervenç̃o. Fonte: Arquivo, Viva o Centro 
Amaro, Largo 13 de Maio e adjacências, a Rua Senador José Bonifácio e a Praça Floriano Peixoto passaram a ser áreas exclusivas para pedestres

\section{CONSIDERAÇÕES}

Todas as propostas de intervenção no centro intensificaram-se à partir da década de 1970, como resposta ao processo de »decadência« iniciado nas décadas anteriores. Esse processo foi caraterizado pelo abandono dessa área pela elite paulistana, cuja evasão causou um aumento da vacância imobiliária de toda a região central. As intervenções de reabilitação pela EMURB procuraram adequar o centro da cidade para o uso comercial e privado, mas mesmo assim não houve um investimento significativo pela elite na região após os investimentos públicos. A espectativa da EMURB era de que os projetos de reabilitação permitissem que o poder público usufruísse da valorização proporcionada pelo empreendimento privado. Mas essa ideia da divisão do lucro da valorização imobiliária na região central deve ter, no final das contas, ajudado a afastar os investidores. A lógica das imobiliárias segue sempre em maior lucro. Reparti-lo com o setor público não deve ser algo muito atraente.

Porém é necessário identificar dentro da questão urbanística, além da política econômica, o aspecto estético. Com as intervenções de reabilitação no antigo centro da cidade, a EMURB afirmou uma sensibilidade na atuação com os elementos urbanos: $O$ Viaduto, o Edifício e a Rua do pedestre são as testemunhas, que representam na pesquisa, essa experiência. A EMURB, composta por arquitetos cuja formação era enraizada na arquitetura moderna, identificou o centro antigo como um dado ineliminável e sem limites para seu desenvolvimento moderno. Os arquitetos, engenheiros e técnicos da empresa pública atribuíram aos projetos históricos analisados, valores que exercem novas funções: a rua virou calçadão, a ponte de veículos foi transformada em um viaduto de pedestres, e o degradado edifício Martinelli virou um prédio

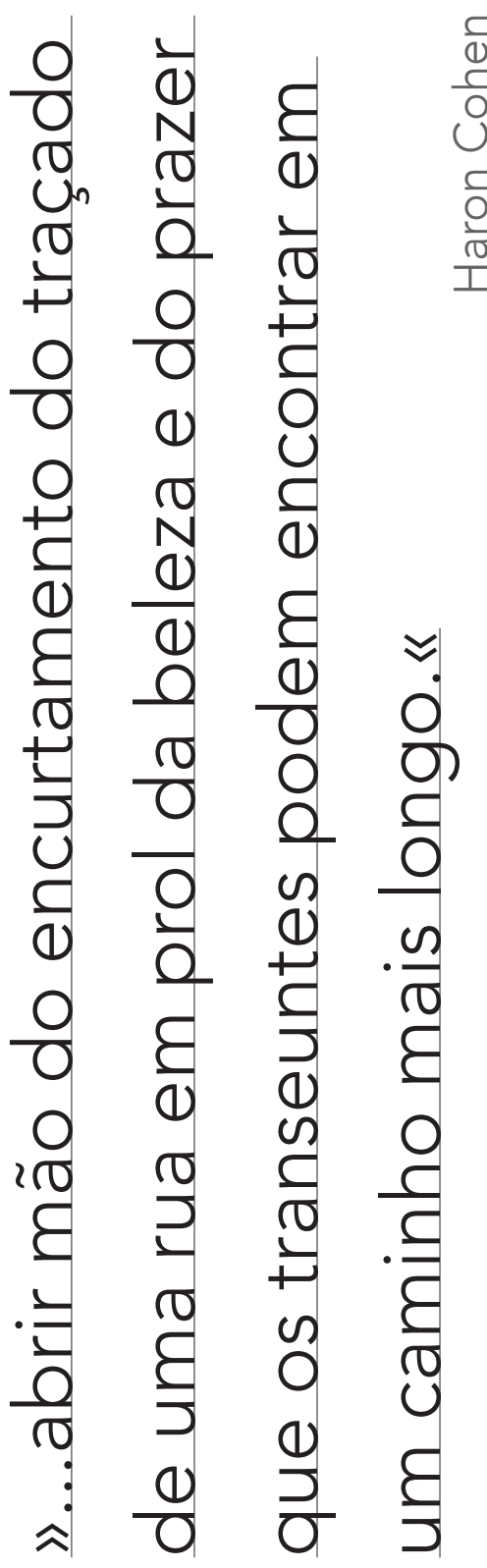


de escritórios, mantendo seu uso comercial no térreo. As novas funções protegem as funções testemunhais do antigo conjunto de elementos arquitetônicos na paisagem urbana. O Edifício Martinelli, por exemplo, evoluiu de acordo com as diretrizes da segurança e requisitos técnicos da época, preservando sua integridade, sem mumificar o conjunto. Giulio Carlo Argan descreve essa leitura cuidadosa no campo da preservação assim:

»[...] o centro histórico de uma cidade não pode se tornar um museu. Mas pode continuar uma obra de arte. Para conservar as obras de arte temos um procedimento cientifico, o restauro, e este é a consolidação das velhas estruturas mas também a eliminação racional dos acréscimos incongruentes. $\ll^{9}$

Os projetos apresentados pela EMURB contribuíram com um planejamento urbano significativo para a cidade de São Paulo. As interven-

9 ARGAN, Giulio Carlo, Projeto e Destino, Editora Ática, 2Ed. 2011, São Paulo, p. 105 ções representam valores - refletem a história, o tempo e a beleza. $O$ cidadão que usufrui desses valores é capaz de compreender o sentido do trabalho humano imbuído nessas obras, que acabam sendo responsáveis por constituir a identidade dos habitantes da cidade onde se situam. As obras da EMURB foram realizadas por profissionais altamente qualificados da área de arquitetura e engenharia, como o primeiro diretor da EMURB Roberto Cerqueira César (Ex-sócio de Rino Levi) ou nosso fio condutor para essa pesquisa - o arquiteto Geraldo Vespaziano Puntoni. 

fillin

[Recorte 1973 - 1979]
EMURB - Empresa Municipal de Urbanização

[Recorte 1970 - 1973]

MIKA

[Recorte 1967 - 1970]

[Recorte 1963-1967]

FECE - Fundo Estadual de Construções Escolares

[Recorte 1961 - 1990]

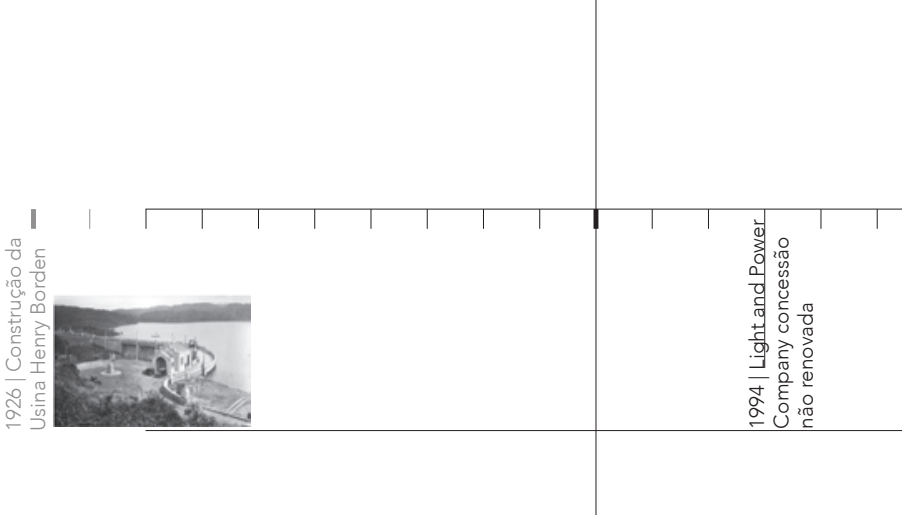

WIIn 是 是

ars de Öbras Públicas

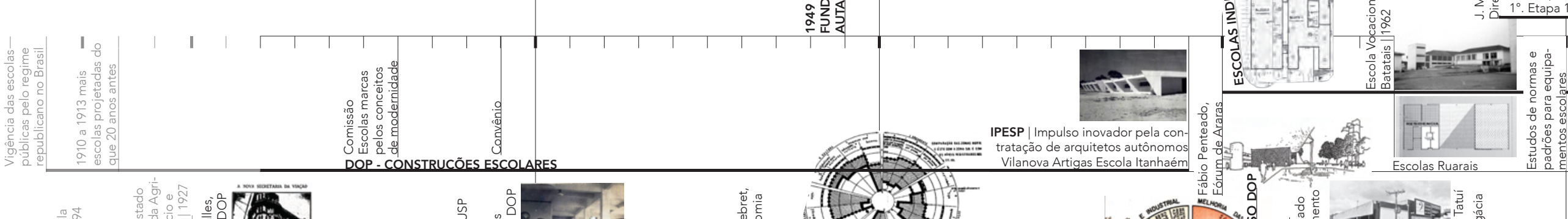

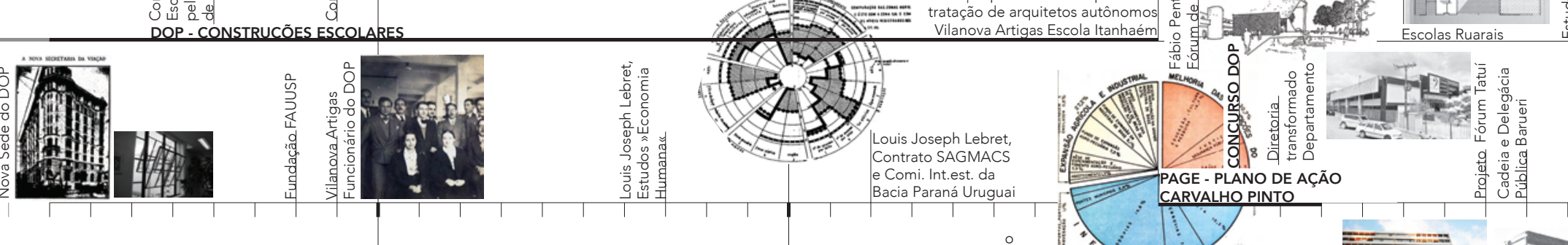





\section{LISTA DE PROJETOS}

Gerente dos estudos de viabilidade econômica e financeira do Projeto CURA - Comunidade Urbana de Recuperação Acelerada, programa do Banco Nacional e Habitação - BNH

Coordenador dos estudos da implantação do projeto CURA

Chefe de Departamento CURA

Coordenador designado pela Diretoria de Planejamento da EMURB

Prédio Martinelli

Ruas de Pedestres no Centro

Viaduto Santa Ifigênia
Na área piloto da Vila das Mercês e na área pi-

$1973-1974$

Na área piloto de Jabaquara no Município de

São Paulo

$1976-1978$

Projeto de urbanização »Cidade Fernão Dias«

1979

Restauro e revitalização do Prédio

1975

1976

Restauro da ponte

1978 



\section{BIBLIOGRAFIA}

Obras de referência do arquiteto Geraldo Vespaziano Puntoni: Acervo particular do arquiteto

ARGAN, Giulio Carlo, Projeto e Destino. Editora Ática, $2^{\circ}$ Edição, São Paulo, 2011

ANELLI, Renato. "Redes de Mobilidade e Urbanismo em São Paulo: das radiais/perimetrais do Plano de Avenidas à malha direcional PUB". Arquitextos, n. 082. São Paulo, Portal Vitruvius, mar. 2007

EMURB, Empresa Municipal de Urbanização. A Reurbanização de Santana e Jabaquara. São Paulo 1973

EMURB, Empresa Municipal de Urbanização. Prédio Martinelli. São Paulo, 1973

EMURB, Empresa Municipal de Urbanização. Cidade Fernão Dias. São Paulo, 1979
EMURB, Empresa Municipal de Urbanização. Reurbanizações. São Paulo, 1979

EMURB, Empresa Municipal de Urbanização. Viaduto Santa Ifigênia. São Paulo 1979

EMURB, Empresa Municipal de Urbanização. Ruas de Pedestres. São Paulo 1979

EMURB, Empresa Municipal de Urbanização. Política e Obras Fortalecem Cidadania. São Paulo, 1992

FELDMAN, Sarah. Planejamento e Zoneamento, São Paulo 1947-1972. Edusp, 2005

LUCCHESE, M.C. Curam-se cidades: uma proposta urbanística da década de 70. Dissertação de Mestrado, FAU USP, São Paulo, 2004
REIS FILHO, Nestor Goulart. Dois Séculos de Projetos no Estado de São Paulo, Grandes Obras e Urbanização. Volume III, 1930-2000. Edusp, imprensaoficial, 2004

HECK, Eneida Regina Belluzzo Godoy. A EMURB como instrumento de planejamento urbano em São Paulo 1971-2001. Dissertação de mestrado. São Paulo, FAU-USP, 2005.

SÃO PAULO, Prefeitura Municipal, ASPLAN, DAILY, MONTREAL, WILBUR SMITH. Plano Urbanístico Básico. São Paulo, Prefeitura Municipal, 1969.

SEGAWA, Hugo. Arquiteturas no Brasil 19001990. São Paulo: Edusp, 1999. 


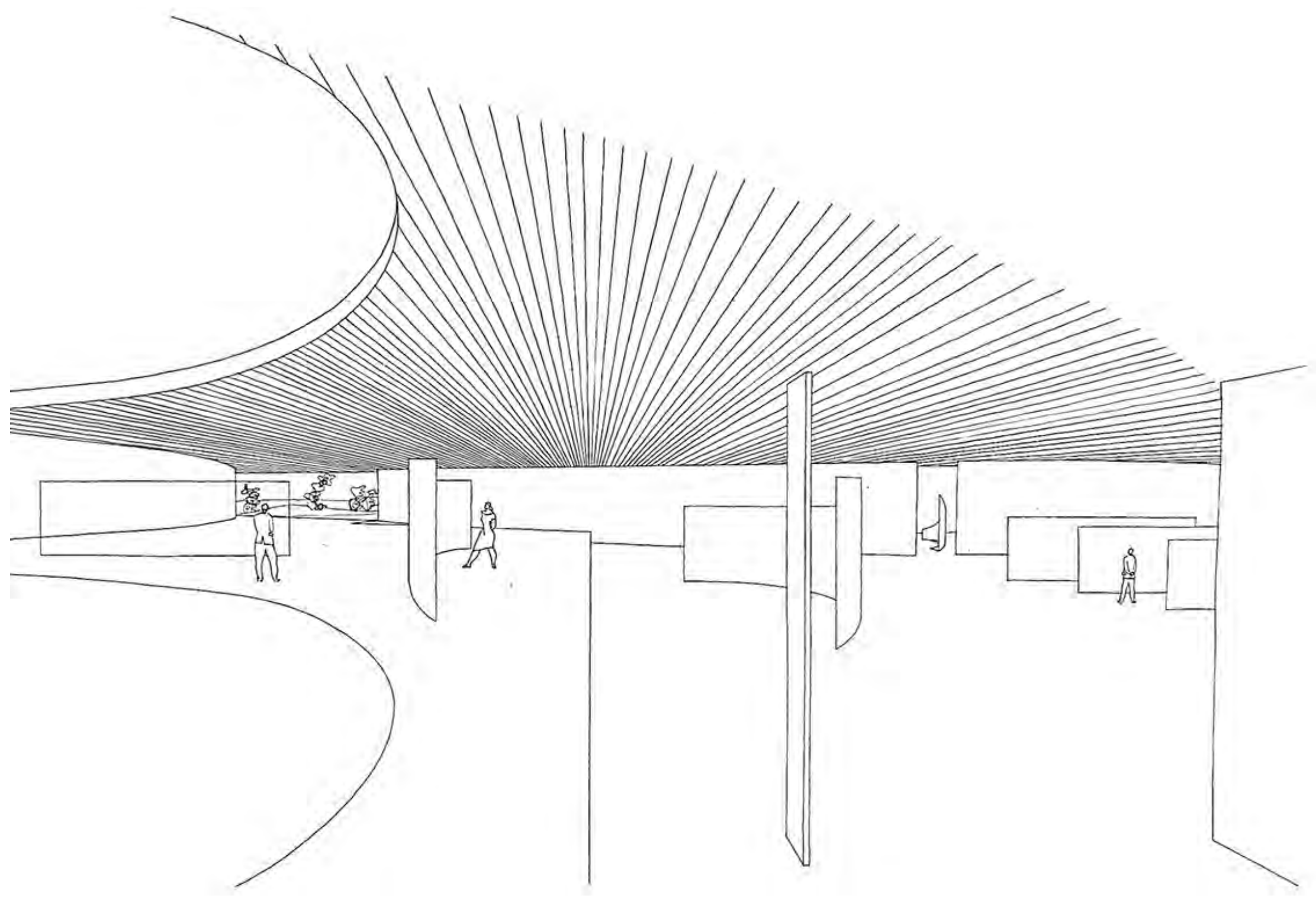




\section{CONSIDERAÇÕES FINAIS}

\section{[O ARQUITETO \& O MUNDO]}

A carreira do servidor público Geraldo Vespaziano Puntoni se encerrou com sua atuação no Instituto de Previdência do Estado de São Paulo - IPESP, em 1990.

»Eu me aposentei no IPESP, quando eles criaram o $\mathrm{CPOS}^{1}$. Eu já estava com trinta anos de trabalho no DOP, então eles vieram para conversar comigo para que eu pedisse a demissão. Eu recusei. Daí eles falaram para nós escolhermos uma autarquia. Uma grande parte do DOP foi para o DAE (Departamento de Águas e Esgotos). Eu e mais quatro colegas do DOP fomos para o IPESP. $\ll^{2}$

1 A CPOS - Companhia Paulista de Obras e Serviços é a sucessora do DOP, registrada na Junta Comercial do Estado de São Paulo - Jucesp, em 25/10/1991, tem como principal acionista o Governo do Estado de São Paulo e a Companhia de Processamento de Dados do Estado de São Paulo. A CPOS é uma empresa de economia mista de direito privado e financeiramente não dependente do Governo do Estado de São Paulo.

2 Entrevista, Geraldo Vespaziano Puntoni, Clementina Delfina de Ambrosis, Domingos Teodoro de Azevedo Marques, 26.05.2014
O DOP foi extinto, em 1991, pelo governador Orestes Quércia (1987-1991), através da Lei Estadual $n^{\circ} 7.394$ de 08/07/1991, que autorizou a transformação do Departamento de Edifícios e Obras Públicas - DOP, para empresa Companhia Paulista de Obras e Serviços - CPOS.

Geraldo Vespaziano Puntoni permaneceu somente de 1989 a 1990 no IPESP, pois em 1990, o servidor público se aposentou. $\mathrm{O}$ Instituto de Previdência já tinha ultrapassado os seus momentos significativos durante as décadas de 50 e 60, quando organizou e financiou diversos edifícios públicos em quase todos os municípios do estado através do PAGE. O IPESP não é o ponto inicial nem o ponto final desta pesquisa, pois compreendemos a linha do tempo como um conjunto de partes que se associam para uma trama de relações que não tem início nem fim, e sim configuram um processo contínuo. Portanto, parece oportuno retomar o momento duran-
IMAGEM 148. Desenho Geraldo Vespaziano Puntoni, Concurso Nacional, PavilhãoBrasileiro,Expo70,Osaka,Japão,PerspectivaInterna,Fonte:Arquivo 
te o Plano de Ação (1959-1963), quando o IPESP era responsável pela contratação de arquitetos autônomos. O PAGE, foi uma exceção, no qual os arquitetos modernos, puderam exercer suas proposições de vanguarda. Eles propuseram espaços generosos para socialização e criaram novas relações entre o edifício e o espaço urbano, enfim, não respondiam necessariamente uma norma de trabalho. O golpe de 1964 recompôs em todos os níveis o aparelho do Estado, ajustando o Brasil ao cenário internacional segundo Tafuri. As ideias modernas, que no PAGE não andaram na direção da pré-fabricação, foram substituídas pela normatização administrativa, funcional, e técnica do Estado. A normatização gerou projetos padronizados, e os espaços abertos e dinâmicos articulados com o espaço urbano foram substituídos por monótonas repetições que não constituíram uma proposta inovadora. As oficinas de projetos públicos do estado capturaram as formas modernas, porém os utilizaram segundo suas necessidades. Os arquitetos dos órgãos públicos foram obrigados a se transformarem em técnicos de normatização, que tinham como referência o modernismo. Os arquitetos faziam uma arquitetura dentro do que era possível, desprovida de investigações e novas possibilidades. Segundo Marlene Picaelli:

»Tinha um arquivo com os desenhos. Você pegava lá a fachada principal e você estudava, se ela se adaptava naquele lugar. Era uma locação de fachadas! «3

Esse conflito foi para muitos funcionários públicos perturbador, principalmente para aqueles com tendências progressistas. Um deles foi o servidor público Geraldo Vespaziano Puntoni, identificado pelo Departamento de Ordem Política e Social (DOPS) como militante do PCB. Testemunhas inquietas são os protocolos de interrogação e as anotações sobre os suspeitos que não pretendiam alinhar-se ao regime repressivo. O afastamento de Vilanova Artigas, como Diretor da FAU USP, em 1969, é um exemplo, além de muitos outros da intelectuali-

\footnotetext{
3 Entrevista, Marlene Picarelli, 04.07.2016
} 
dade que foram silenciados pelo regime militar.

arquiteto Geraldo Vespaziano Puntoni conseguiu assumir os compromissos para a construção dos bens coletivos dentro do quadro dos órgãos públicos. Resistindo aos limites estabelecidos pelo regime e encarando os desafios de uma realidade social caraterizada pelo atraso de sua infraestrutura e sua falta de equipamentos públicos adequados

A resistência política de Geraldo Vespaziano Puntoni permitiu a realização e a busca constante pela qualidade do desempenho destas obras públicas apresentadas. Esta dissertação se desdobra através da figura do servidor público, que foi capaz de esboçar uma trajetória com interligações entre diversas partes: seis órgãos públicos, áreas de atuação distintas, projetos com escalas variadas, circunstâncias políticas diferentes e personagens diversos como arquiteto, engenheiro, paisagista, político, padre, professor, cientista, e todos os outros atuantes que tinham como palco de inspiração um sonho
SECRETARIA DA SEGURANÇA POBLICA

DIVISRO DE IMPORQAGEES $=$ CPI/DOPS.

$$
52 \cdot 2-0-14472
$$

\section{GERATDO VESPAZIARO PUNTONI.}

F111ação: Italo Punton1 o Noem1a Dalla Dea Punton1.

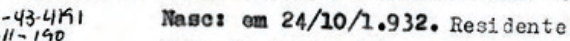

Nat. de Rrotas/sp.

Conforme anotaçōes em nossos arquivos, cumpremnos informar $\circ$ segulnte:

Im 03/12/1.970, nas đeclarações prestadas pe-

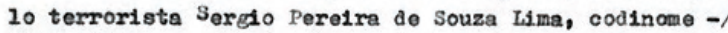
"SEVERINO", quando da prisão declarou conhecer Ge-

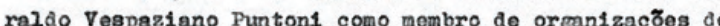

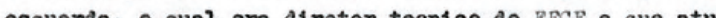
esquerda, O qual ora diretor tecnico do PBCE e que atu-

\section{im 18/12/1.970, fo1 encontrado nas anotaç̋es} om poder do terrorista Sergio Pereira de Souza IÁma, pe om poder do terroriata Serge one Geralao Vegpaziano Punton1, anotadoz Arouito0 nome de Gera.
to da C.E.S.P.

3n 29/10/1.974, a Delegacia Regional ao Tra-/ balho no satado de São Paulo, Informa-nos o reaul tado da ele1 ção da Diretoria do indicato dos Eatabelecimentos de Insino Secundárí no Sstado de São Paulo, a qual elegen Ae, tendo tomado posse no dia $08 / 10 / 1.974$.

Informação $n^{2} 2469 / 75$, datada om $27 / 11 / 2.975$, referente a participação de Cristina de Castro Kelo, no $\mathrm{PCB}$, consta o nome de Goraldo Vespaziano Punton1, ele1. to juntamente com a declarante para o cargo de "secrete. rio da Base dos Arquitetos, tendo a1do substituido por

IMAGEM 150. Ficha DOPS de Geraldo Vespaziano Puntoni, Secretaria da Segurança Pública, Fonte: Arquivo Público do Estado POLICIA CIVIL DE SĩO PAULO

"DIVISRO DE IMFOPAIACOES - CPI / DOFS"

cont1nuaçãos F1s. 2. )

por Haron Cohen. $O$ epigrafado, desligou-se do Partido no 1nicio de 1.974. 50-8-8-1904

no Inicio de 1.974. $30-\mathrm{C}-1-2367$

InP.p/a D.O.S., on 25/10/76)

Bocumento oriundo da Faculdade de Belas $\mathrm{A} \underline{\underline{T}}$ tes de São Paulo, de $17 / 11 / 76$, nos cientifica que o/ focalizado, professor a ser contrado para o curso de arquitetura e Urbanisto daquela entidade educacional, não teve a sua solicitação aprovade pelo Conselho $\mathrm{Fe}-$ deral de Bducrsão - C.F.F., conforme parecer ne 3799/

776 . $50-7-704-2.305$

Inf.y/a D.C.I., en 03/03/77

Conforme PRI No 8/76-CIE de 10/9/76, const que o mareinado é arquiteto e wa dos olementos que con titui o comitê cultural do $a z / s$.

$30--1-24519 \cdot 2$.

Conforme in formaģão lir za4 - Div. đe Orçen Social, arguivada neste OPI aos $22 / 0 / 77$, consta que em 19/12/75, atrovés do ofŕcio 887/75 co Gudo. co II Exército encaminha relaģão cos elementos que pocerão ser indicados en inquérito policial, constando sobre o norinaao: Zno presiciente do Sindicato dos Arouitetos militonte is Pas.

$10-2-11-190, z$.

O marcinażo prestou ċeclar çốes no Divisão

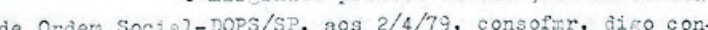
forme sezue ex anexo.

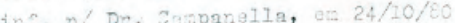

IMAGEM 149. Ficha DOPS de Geraldo Vespaziano Puntoni, Secretaria da Segurança Pública, Fonte: Arquivo Público do Estado 
em comum: lutar para efetivar o avanço do país. As grandes oficinas de projeto dos órgãos públicos realizaram uma quantidade imensa de projetos, e chegaram a adquirir um grande conhecimento sobre obras. Infelizmente, raramente encontramos dados disponíveis, seja por desinteresse dos próprios órgãos ou da instituição sucessora. Uma parte do arquivo do DOP, foi transferida para o CPOS, enquanto a biblioteca do mesmo órgão foi doada para a FAU USP que, segundo Geraldo Vespaziano Puntoni, foi descartada pela própria biblioteca da FAU.

»Eu dava aula de desenho, quando cheguei na minha sala, estava lá um canto cheio de livros. Peguei um livro. Sabe o que era? A biblioteca do DOP. Qualquer aluno podia pegar. Eu fui falar com a biblioteca, dai eles falaram que tudo era para ser descartado! A biblioteca do DOP era um arquivo cultural. $\ll^{4}$

Assim vem se perdendo gradativamente a oportunidade de discutir as experiências das obras

4 Entrevista, Geraldo Vespaziano Puntoni, 04.07.2016 públicas do Estado de São Paulo, seja por questões ideológicas ou simplesmente pela falta da consciência do valor da memória.

Esta dissertação tem como objetivo recapturar o registro das obras relevantes e os depoimentos dos seus agentes deste período da arquitetura em São Paulo. Supõe-se que o reprocessamento das décadas de 60 à 90 pode contribuir para um norteamento diante da discussão da arquitetura contemporânea. $\bigcirc$ registro dessas obras públicas construídas, servem como lugar de afirmação, de consulta e de crítica para contribuir com os projetos futuros.

»A constituição de uma coisa qualquer pressupõe uma dupla perspectiva temporal, sobre o passado e sobre o futuro. O primeiro homem que fabricou um copo para beber e, depois de ter bebido, guardou-o para se servir dele. Sobre uma experiência passada construiu um projeto para o futuro. $\ll^{5}$ A atuação do arquiteto Geraldo Vespaziano

\footnotetext{
5 ARGAN, Giulio Carlo, Projeto e destino, p. 16, 2001
} 
Puntoni apresentou obras em diversas disposições com ênfase na construção da cidade, do estado e do país.

O concurso do Pavilhão Brasileiro na Exposição Mundial de Osaka, em 1970, aqui apresentado com seus croquis, foi o primeiro do arquiteto autônomo para um país estrangeiro. Um projeto notável que revela sua compreensão do que é o Brasil na disposição do mundo. O projeto demonstra o desenvolvimento do homem contemporâneo, dentro de uma visão global da cultura de todos os povos. No memorial o arquiteto descreve a sua proposta:

„O partido adotado toma o »lote« do Brasil

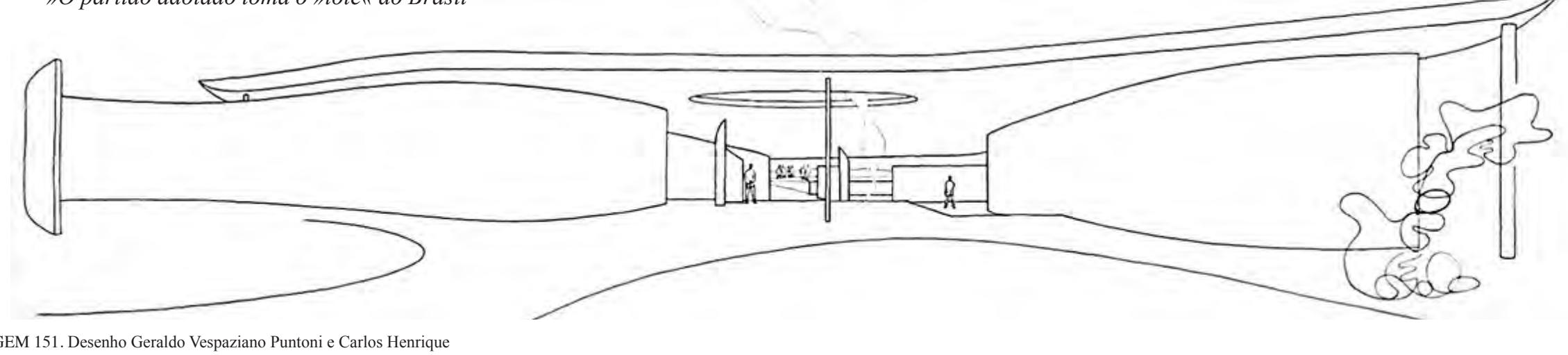

IMAGEM 151. Desenho Geraldo Vespaziano Puntoni e Carlos Henrique

Heck, Concurso Nacional, Pavilhão Brasileiro, Expo 70, Osaka, Japão,

Perspectiva Interna, Fonte: Arquivo Escritório Grupo SP 


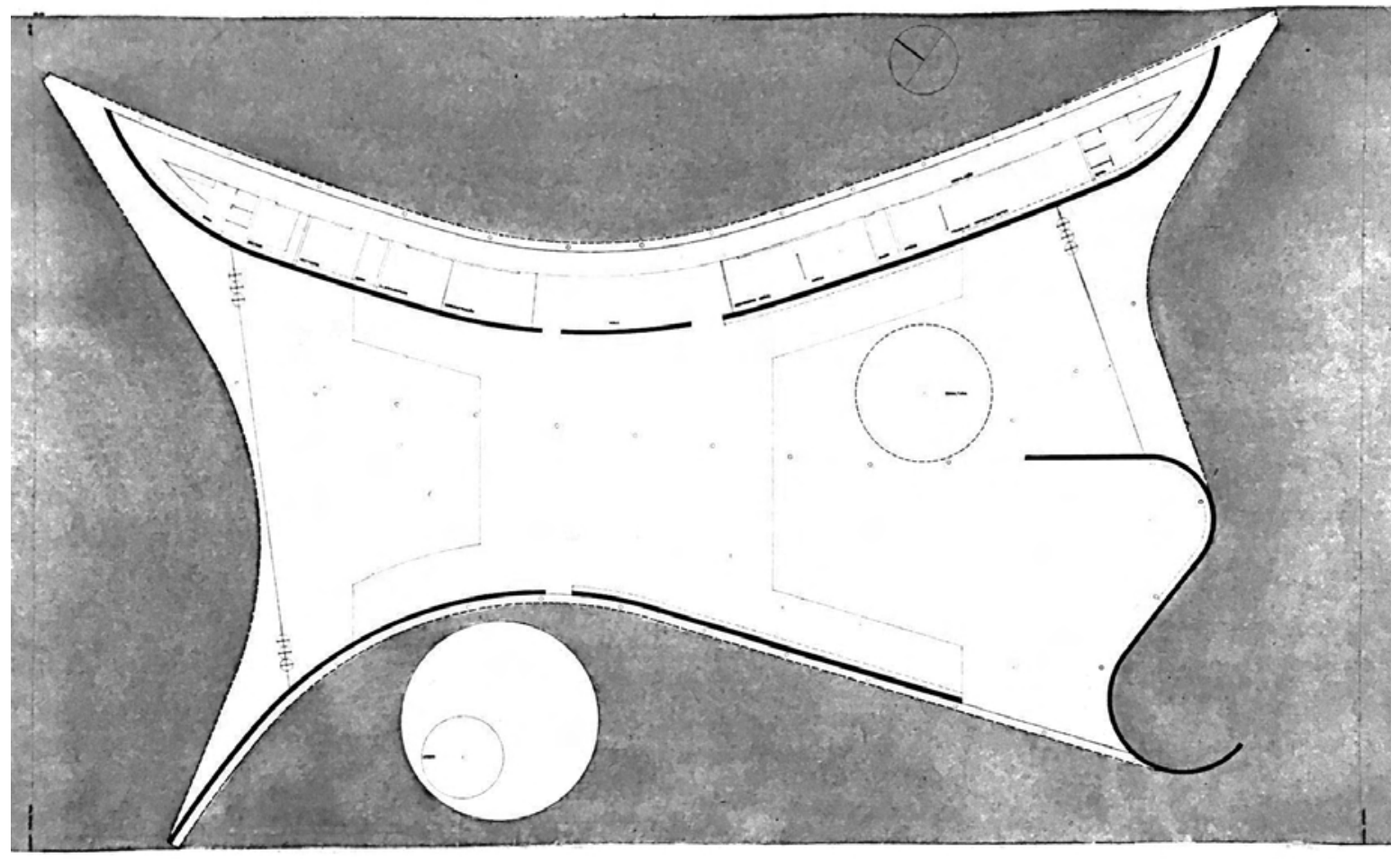

Planta e transforma-o no próprio pavilhão. Com insignificantes movimentos de terra, cortes, planos e rampas, define-se uma circulação correta e simples. Apresenta-se, então, uma solução, que com duas grandes aberturas de entrada, como se convidassem todos os povos para um passeio maravilhoso na praça pública. « ${ }^{6}$

pavilhão se organiza através de dois muros, alguns terraplenos, e uma grande cobertura. Essa cobertura se desenvolve ao longo do eixo maior do terreno, ligando visualmente as duas ruas. Algumas aberturas zenitais criam volumes esculturais com a própria luz do sol. Nos extremos localizam-se duas grandes entradas, como se convidassem os visitantes a um passeio de praça pública. O terreno é o próprio pavilhão.

arquiteto Geraldo Vespaziano Puntoni propõe como pavilhão uma praça pública para convivência, gerada a partir de uma grande cobertura e do desenho dos pequenos des-

6 PUNTONI, Geraldo Vespaziano, Memorial do concurso público, Pavilhão do Brasil, Osaka, Japão, 1970.
IMAGEM 152. Desenho Geraldo Vespaziano Puntoni e Carlos Henrique Heck, Concurso Nacional, Pavilhão Brasileiro, Expo 70, Osaka, Japão, Planta, Fonte: Arquivo Escritório Grupo SP

206 
níveis no solo, uma declaração de filiação com a arquitetura moderna paulista. $\bigcirc$ pavilhão se destaca pela ausência de monumentalidade ou de efeitos efêmeros de uma tecnologia artificiosa. Um pavilhão para exposições que assume as caraterísticas de uma construção provisória e evita assim simular artificiosamente uma obra de permanência.

A linha do tempo construída nesta dissertação pretende contribuir como registro de uma trajetória notável, marcada pelo trabalho intenso de um profissional íntegro e responsável. A modernidade no Estado de São Paulo está muito além dos projetos de poucos arquitetos muito publicados e aclamados pela crítica; se construiu a partir de um grande grupo de profissionais, de diversos orgãos públicos que precisam ser conhecidos e estudados, de modo a manter viva a memória destes espaços.
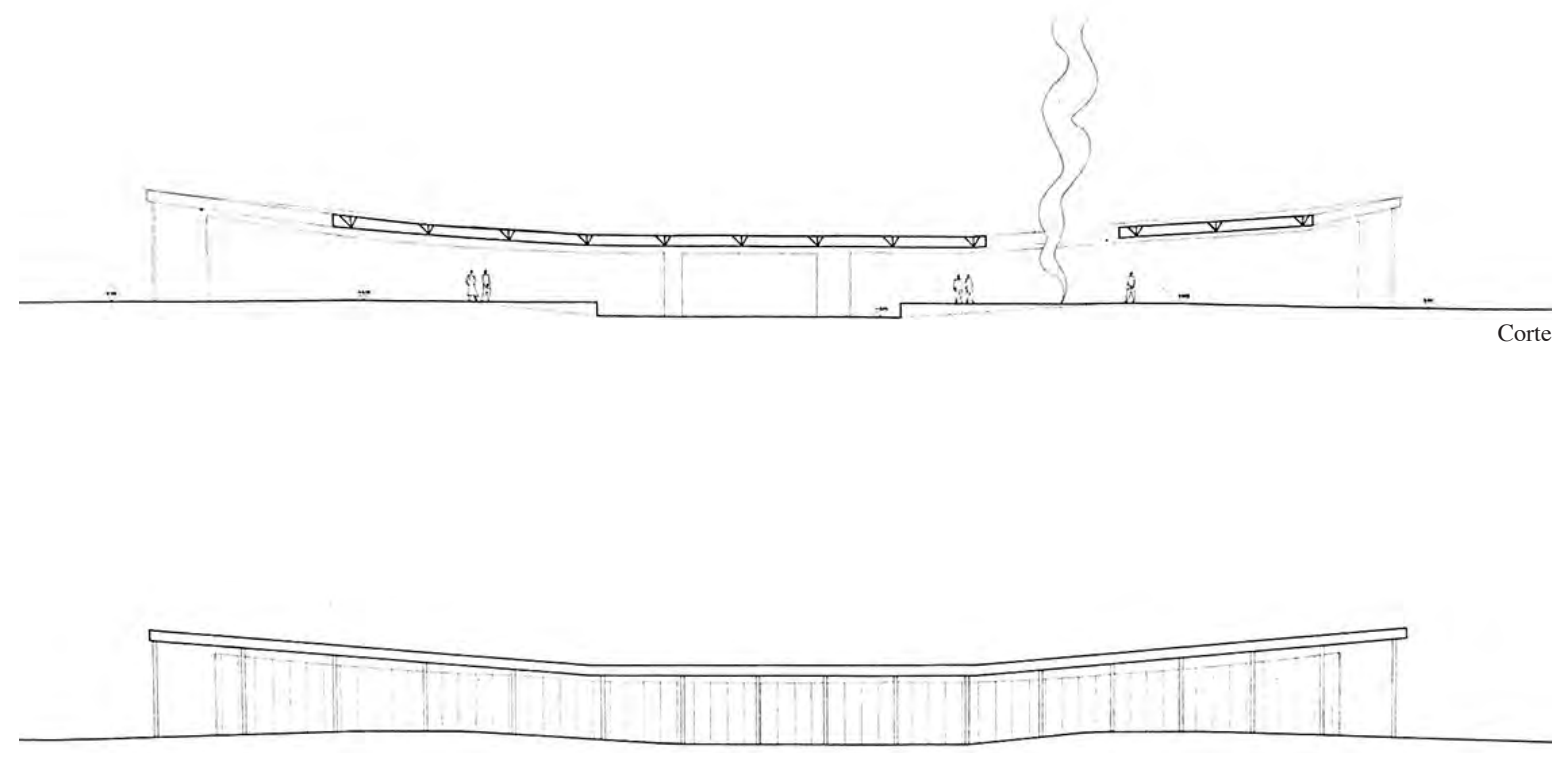

Elevação

IMAGEM 153. Desenho Geraldo Vespaziano Puntoni e Carlos Henrique Heck, Concurso Nacional, Pavilhão Brasileiro, Expo 70, Osaka, Japão, Corte e Elevação, Fonte: Arquivo Escritório Grupo SP 



\section{ANEXO 1}

\section{[ENTREVISTAS]}

\section{Entrevista. \#1}

Data . 26.02.2014

Participação .

Anália Amorim

Geraldo Vespaziano Puntoni

Sebastian Friedrich Beck

\section{Anália}

Na cabeça de 40-60 anos de trabalho. Na cabeça dos homens que fizeram a arquitetura brasileira. Não só vocêfez, mas você estava trabalhando nessa convivência principalmente arquitetura paulista.

O que a gente imaginou:

Eu conversei um pouco com Alvaro quando tive a ideia. A primeira pessoa foi o Sebastian, porque o trabalho dele de mestrado já especula sobre arquitetura brasileira. A ideia era fazer o seu roteiro e o que é a sua trajetória trouxe de vivência e tanto propiciou como você conviveu com essa geração - eram poucos na época.

A primeira ideia era uma visão cronológica - para facilitar a nossa vida. E o Alvaro falou uma coisa bonita, que era ter o seu trajeto e as vertentes que foram surgindo da sua vivência com sua formação. A gente pode começar desde da sua escolha por arquitetura. Um roteiro - eu penso cronológico porque a visão histórica é a primeira, é mais fácil.

\section{Vespaziano}

É muito individual a coisa que será dita aqui porque realmente os testemunhas mais significativas já deixaram de existir, praticamente. Tem caso que as vezes até algumas coisas que eu irei citar vai transparecer como propriedade, como sítio.

$\mathrm{Na}$ realidade eu venho do interior e o meu destino era ser comerciante ou ajudar, meu avô. Ele tinha um grande armazém, meus tios trabalhavam lá. Eu fui criado pelo meu avô em Brotas.

\section{Vespaziano}

Não havia perspectiva de fazer algum curso além do grupo escolar, porque isso era o suficiente para o meu destino lá que era trabalhar talvez no comércio. Meu avô cuidou da parte de empreendimento qualquer. Mas houve um acontecimento significativo, que era eu gostava muito de desenhar, desenhar, desenhar..

Isso despertou o interesse de um tio meu, casado com a irmã de minha mãe. Ele resolveu interferir com 
meu avô. Eu não sei o que foi a conversa, só sei que ela conseguiu me trazer para São Paulo para estudar. Ai eu comecei estudar, naquela época só havia colegial, não havia nada não.

Curso de Padre, internato, dai ele me matriculou no Colégio Bandeirantes. Eu já estava com doze anos. Por isso en estou meio tarde. No Bandeirante eu me envolvi, estudei e fui um aluno exemplar. Nas ferias eu falei com minha mãe, que eu não estava mais afim ficar na casa do meu tio.

Ai eu prestei o colégio do estado, e a minha mãe estava casada pela segunda fez. Ela começou a pagar a pensão para mim. Eu tinha um tio, irmão do meu pai, que fez cobertura, alias ele trabalhou aqui em frente (Rua General Jardim, 65), tinha uma casa que era o frigorífico do prédio da Secretaria de Saúde. Um outro escritor famoso Alfonso Schmidt, ele escreveu vários livros sobre São Paulo. Como escritor ele é muito interessante, eu tenho todos os livros dele, ele fala muito sobre São Paulo, ele é um escritor descritivo, ele narra, fala da cidade - interessante! ...Telégrafo, trata de uma moça que mora, trabalha 210 num cortiço no Brás e vem trabalhar - coisas de São Paulo. Tem um que fala de uma Plantação de Banana-Historias interessantes!

\section{Anália}

E sua primeira Pensão era onde?

\section{Vespaziano}

Então a primeira Pensão onde eu morei, eu estava no segundo ano do Ginásio, no Colégio do Estado Presidente Roosevelt, Parque Dom Pedro, onde meu curso foi de graça. Daí minha mãe resolveu pagar a pensão do meu tio, o irmão do meu pai. Aí, eu morei no Lago do Correio. Foi na época quando começou a obra no Vale do Anhangabaú.

Dali eu passei a morar perto da Rua Tutoia. Eu morava aqui no Largo do Paiçandu.

Sempre morei no Centro...

Depois fiquei morando um tempo com meu tio, o irmão do meu pai..

Depois morava com amigos, colegas de escola, coisa de aventura. Mais perto do Colégio Roosevelt. $O$ Roosevelt só tinha Ginásio, no parque Dom Pedro, na Rua São Joaquim - Onde Paulo Mendes da Rocha acaba de fazer um projeto. O Projeto do Lago foi depois. Depois eu vim morar na Rua Caio Prado, eu já tinha entrado na Faculdade, na FAU USP.

Mas engraçado, que eu não ia fazer arquitetura realmente. Eu estava me preparando para fazer medicina. Meu interesse estava medicina. Não sei explicar, porque não tinha modelo nenhum na minha família. Mas ai por algumas razões - eu acabei sendo colega do Eduardo de Almeida. Acho que nós conhecemos no Colégio do Estado. A gente frequentava muitos museus de arte, então começamos a conversar sobre essas coisas. E ai surgiu a FAU e eu resolvi prestar o vestibular na FAU e na Medicina.

Anália

Tinha a ver a sua escolha de medicina com a sua conduta social?

\section{Vespaziano}

Eu acho que talvez tivesse. O que me influenciava muito, é que eu morava num bairro, que se confrontava com um número alto de negros ... mais ainda para nós italianos. Como eu era moleque de rua, eu tinha 
amigos negros. Eu acho isso estava me influenciando muito, essa discriminação. Eu estava até brincando com meu avô. Vocês Italianos apelidavam o bairro dos negros de »pita acesa». Porque »Pita Acesa»? Porque não tinha luz - não tinha luz nem esgoto. Vamos dizer uma Favela naquela época, só com mais espaço. O Bairro do meu avô acabou sendo chamando de »Bairro do Pita aceso«. Transbordou! Tão significativo esse apelido. Não sei se tem esse nome ainda. Mas talvez seja uma razão. Talvez seja isso. Esse convívio com essa gente. O pessoal andava descalço, sempre nu, desatento, alcoolizado, subemprego, misere da nada. Provavelmente as mulheres eram prostitutas ou prostituídas. Não sei, eu era criança.

Quando eu entrei no Roosevelt comecei por alguma razão participar do Grêmio Roosevelt, ai eu comecei a participar do movimento estudantil - chamava UPES - União Paulista dos Estudantes Secundaristas. Começou então o meu envolvimento com a política quando fui a um congresso da UPES, que foi aqui no Sindicato dos Barbeiros. A Praça Roosevelt era definida. Na frente da Rua Consolação tinha uma casa, lá tinha o Sindicato dos Barbeiros. O con- gresso da UPES foi lá. Durante a assembléia houve um ataque dos Integralistas, com uma violencia da nada - foi um bafafá! Naquela época eu acho que era a ditadura do Getúlio, 1945 terminou a guerra. Eu não estava envolvido com os comunistas nessa época, mas foi a primeira vez que eu conheci Urieta (a Mulher do Fernando Weiss), cuja a mãe era uma famosa comunista, Elisa Branca, ela ganhou um prêmio do estado da Paz. Elisa Branca era uma personagem! A história dela está mais ou menos contada no livro do Pereira Silva, "Diário de um Cientista Subversiva«. Fala da Elisa, fala da comuna toda, da época dele. Inclusive ele era colunista, ela foi presa, duas vezes, foi caçada, ela era professora da USP com Samuel Pessoa. Elisa Branco e Pereira Silvavale a pena ler este livro. Ele foi diretor do Instituto Pasteur. Quando ele foi caçado ele foi para lá. Ele não conseguiu Passaporte porque ele tinha aceitado um emprego desporte sem pedir autorização para ... Muita contradição isso ai.

O problema do comunismo veio para mim, como eu estava fazendo »cursinho" para medicina eu fui fazendo »cursinho« no Prof. Di Túlio, e depois, lá dentro no Prof. Di Túlio mesmo, eu mudei para fazer curso de Arquitetura. Eu estava estudando química, fisica, biologia... Eu fiquei muito amigo do Prof. Pompeio Di Túlio. Dai eu conheci o Prof. Vicente De Cozzi. Ele era professor de desenho. Eu comecei a fazer apostila, eu, e um outro colega. Eu imprimia não que eu escrevia. O Di Túlio levava no final de semana a gente para Santos e a gente estava conversando...

Até que eu entrei na FAU. Quando eu cheguei na FAU, estava lá um cara que se chamava Ruy Gama. »O Di Túlio disse para escrever você na JC (Uniao Juventude Comunista)« Não tinha discussão. A minha recepção era o Ruy.

Naquela tempo se dividia se JUC (Juventude Universidade Católica) que era ligado com os Padres Operários. Quando eu estava no colégio eu inclusive frequentei algumas reuniões da JUC, dai eu conheci Julio Roberto Katinsky. A gente se reunia na Rua Higienópolis tinha uma sede lá. Os Padres eram muito interessantes. Eu gostei muito destes caras! Mas religião não era um assunto que me interessava. Eu já tinha sido coroinha. Não era a minha vocação de ser 
padre. Teve na JUC, participei em algumas debates, tinha até algumas coisas interessantes. Mas eu nunca me envolvi com este assunto.

Aí eu comecei com as atividades no grêmio da FAU, achei mais importante. Assisti aulas, mas uma coisa curiosa, os professores da esquerda - eu não podia imaginar que o Artigas fosse da esquerda - ou comunista. Ele não tinha está antecedência. Aí eu vivi cinco anos no grêmio, cheguei até ser vice presidente. Eu fui o vice presidente do Renato Nuno. Eu trabalhava no departamento das publicações, sempre estava nas diretorias. Achei interessante, importante e significativo. Eu dava mais valor para as proporções do grêmio do que para a própria escola. A ponto que eu acabei assumindo em função da JC, eu fui presidente do diretório estudantil do Juscelino Kubitschek, da campanha do JK, perto do Largo do Café, Na Rua São Bento. Fiquei seis meses. Isso me levou ficar assentado na FAU durante muito tempo. Com os professores inteligentes eu fui conversar, eles falaram não tem problema, faz um trabalho tal, tal, tal... Mas tem um Professor que me reprovou. Eu tive que fazer mais uma composição arquitetônica. Deixei a 212 minha turma. [...] Mas isto foi bom, para mim foi mais importante ter sido presidente do Estudantil JK, não ganhei nada com isso, mas ganhei experiência.

O JK ganhou então compensou.

Brasília foi construída!

Inclusive eu me recordo, que em uma circunstância, da família eu ganhei duas passagens para Brasília. Antes de inaugurar houve um evento lá, o sindicato foi para lá. E eu ganhei duas passagens para ir. Quem me deu esta passagem foi o sogro do meu cunhado, um cara importante. Ele é o Doutor Dante Pazzanese. O irmão da minha mulher era casado com a filha do Dante Pazzanese. Ele sabia que eu estudava arquitetura. Mas muito engraçado, na época eu resolvi com colegas da FAU pegar o trem. Saímos daqui em São Paulo, chegando em Três Rios, essa cidade que tem a estrada de ferro, Central do Brasil, ali você ia para Belo Horizonte, Januária, dai pegamos o vapor, descemos o Rio São Francisco, Petrolina. Em Petrolina pegamos a Leste Brasiliense e fomos para Salvador. A Leste Brasiliense ainda existe. Ela não decorria o dia inteiro, ela parava na cidade qualquer, ela não viajava a noite - eu não sei porque. Para essa viagem foram o Júlio - o Abraão ficou com medo de ir - o Janusz.

O Janusz - meu sócio, se formava na FAU, Judeu Polonês, sobrevivente do extermínio. A mãe era médica o pai advogado. Eles perceberam que o Janusz não estava indo bem dai pegaram o menino e puseram ele num convento. Ele tem uma formação religiosa, mas no final ele se tornou mais comunista do que todos. Os pais foram queimados na Segunda Guerra. O Janusz tinha uma tia que andou procurando por ele, e encontrou. A tia trouxe o menino para cá e ele estudou arquitetura. Um menino com uma inteligência ... impressionante! Ele era um cara um tanto »desagradável«, você falava qualquer coisa, ele dizia "você está errado«.

Me recordo de uma história, de uns caras que estavam fazendo CPOR (Serviço Militar), um cara virou e falou »nos fomos dar um tiro com um canhão de $75 \mathrm{~mm}$, e o canhão deu um recuo e quase machucou a gente«, daí o Janusz respondeu, »James, o canhão de $75 \mathrm{~mm}$ não tem recuo«. 
Enio Mainardi (Publicitário), Ubyrajara Gilioli (Arquiteto), José Bussab (Engenheiro) e seu irmão. Eu morava com todos eles também na pensão.

Na viagem do rio São Francisco conhecemos um cara do partidão, não sei qual foi a missão dele nessas regiões, talvez preparando rota de fuga ou juntando os agricultores, pois, as ligas camponesas eram fortes na época.

Anália

Como você identificava um comunista através da conversa nessa época?

\section{Vespaziano}

Comunista para nós era mais tarefeiro, tinha contatos com os líder, com o comando, com alto comando, mas era muito mais para atuar - fazer campanhas politicas. Eu cheguei até fazer um curso no Rio de Janeiro de "Agit Prop"-Agitação e Propaganda. Eu fui para um lugar clandestino, sem saber o percurso, era algo ilegal. Eu aprendi tudo, até fazer um »Molotov«, estudamos Marx, Lenin e todos os documentos essenciais. Havia um trabalho de educação pelo partido.
A gente nunca soube, quem são as pessoas, as vezes a gente identificou os sotaques - baiano, carioca etc.

\section{Anália}

Qual foi a ideia? Dar um golpe e instituir o partido comunista?

Vespaziano

$O$ ideal era realmente a revolução proletária. Eu conheci Prestes na casa do Samuel Pessoa. Samuel Pessoa era um baita líder do Partido. Durante o Golpe de 1964 eu era presidente do Comitê dos Arquitetos (Não era o sindicado), uma coisa ilegal. Muitas pessoas foram presas, meu tesoureiro, Paulo Bastos. 1964 foi uma repressão terrivel, eu me recordo inclusive em uma ocasião, onde me chamaram para dar cobertura para Artigas, para leva-lo para minha casa. Eu falei que eu não podia, não que eu não quisesse. Paissani falou que o Artigas estaria em perigo, eu não podia garantir para a sua segurança.

\section{Anália}

Você foi preso?

\section{Vespaziano}

Não, eu fui convocado para depor. Eles me perguntaram uma montanha de assuntos. De 2/3 eu nem sabia de que se tratava, tinha coisas que nunca tinha ouvido falar. Mas fiquei no Departamento de Ordem Política e Social (DOPS) que deve ter até hoje a minha ficha. Fiquei lá umas quatro, cinco horas eu estava imaginando que ia ser preso.

Antes de eu me formar eu trabalhei no edificio do IAB no escritório do Wilson Rodrigues de Morais, funcionário do IAB, comunista, eu trabalhei no escritório como desenhista. Quando me formei eu montei o escritório com Janusz. O Janusz, meu sócio tinha muitos contatos com judeus, na época tinha muito empreendimento, assim a gente começou pegar projetos. Qualquer coisa a gente fazia para sobreviver. Nós tínhamos o escritório na Rua Vieira de Carvalho onde tinha em baixo o restaurante Fasano. Depois mudamos para o Palácio do Comércio na Rua 24 de Maio na esquina com o Teatro Municipal e dividimos o espaço com Ruy Ohtake. Ele não foi nosso sócio, mas fizemos um concurso juntos, a escola Federal de São Paulo. 
A gente tinha telefone - era uma coisa raríssima em São Paulo. O Ruy desenvolveu-se como arquiteto e deslanchou. Eu me casei em 1960 e estava com dificuldade econômica, dai eu prestei um concurso. Me formei em 1959. Eu, quando era ainda estudante, eu comecei a dar aula em Ginásios do Estado de desenho. Por isso sou Professor de desenho. Eu estava no quarto ano da FAU quando eu comecei dar aula no Colégio Estadual de Vila Prudente. Não deu para duas pessoas viverem do escritório daí eu prestei concurso.

Era no governo Carvalho Pinto, havia o Plano de Ação. Na época mudou o procedimento federal de recursos para transferir o dinheiro. O Plínio de Arruda Sampaio que era o assessor dele, dai eles resolveram fazer um Plano de Ação (PAGE). E o DOP era algo que construía, assim o DOP ampliou o seu quadro de arquitetos e eu consegui entrar. Você entrava lá, três, quadro meses, você ficava fazendo orçamentos. Você tinha um projeto e você transformava o projeto em uma leitura de quantificar [...]

Um curso de ensino de arquitetura deveria ter uma ação desse porte: Quantos tijolos, quanto de argamassa, quanto de ferro - ler a planta e trans214 formar isso em valores, quantidades, suprimento, mão de obra. Inclusive foi o Ruy Gama que criou os cadernos dos encargos no DOP. Quanto de mão de obra é gasta para $1 \mathrm{~m}^{2}$ de uma parede de um tijolo? Todo mês havia uma apropriação de custo.

Artigas foi funcionário do DOP também. Por sinal, aquele caixilho da FAU é o mesmo do que no pátio interno do Ministério Público do Estado de São Paulo na Rua Riachuelo, 115, que era antigamente o Edifício da Secretaria de Viação e Obras Públicas, Artigas chupou direitinho!

Eu fiquei três, quadro meses no DOP. Existia o Fundo Estadual de Construções Escolares (FECE) a Secretaria de Educação criou esse fundo e precisava de arquitetos. Dai eu fui para o FECE como funcionário do DOP, não deixei de ser funcionário do DOP. Comecei a trabalhar no Departamento de Ensino Profissional para fazer projetos de novas Escolas Industriais. Tinha uma equipe do FECE que era o Professor Tibau, Helio Duarte e Lúcio Grinover. A mão de obra foi eu, Marlene Picarelli, Sílvio Breno, Arnaldo Tonisio. Fizemos nove projetos no Fundo.
O FECE levou essa equipe trainada a trabalhar a fazer o Plano Estadual de Escolas. Quem comandava o FECE era o Flávio Vilaça e a Clementina de Ambrósio, eles fizeram todo planejamento da rede de ensino de São Paulo para aplicar os recursos. Foi daí que foram construídas muitas escolas em São Paulo. O critério de localização em São Paulo foi terreno baldio, campo de futebol, porque era uma carência extrema...Isso foi antes do golpe 1961 à 1962.

Eu comecei fazer um trabalho sobre os mobiliários escolares. Fiz um estudo sobre o padrão de desempenho do mobiliário. Estudei a padronização querendo desempenho, arquitetura deve ser industrializada, a indústria tem que ser solicitada fornecedor equipamento e manutenção. Isso na realidade não deu muito certo. Pedi demissão no FECE. Comecei a dar aula em Santos para poder pagar a escola dos meus filhos. E a minha carreira como arquiteto não deu. Ser arquiteto é carreira de gente rica. Arquiteto, artista plástica são carreiras de gente rica. Para sustentar isso eu não tinha condições. Quando meu sócio morreu, eu fechei o escritório. 


\section{Entrevista. \#2}

Data . 19.03.2014

Participação .

Anália Amorim

Geraldo Vespaziano Puntoni

Sebastian Friedrich Beck

\section{Vespaziano}

[...] Eu toquei no assunto do Departamento das Ordens Públicas (DOP), porque era justamente um órgão que provavelmente foi recriado e inspirado nas obras europeias e [...] Seria a grande oficina de projetos e obras, tanto é que essas miudezas que surgiram, como o Manual Técnico - Caderno de Encargos de Edificações, aquelas coisas todas, surgiram lá dentro. Mas aí, o próprio departamento elaborava projetos, muitos projetos. Os primeiros modelos foram feitos lá, os de escolas, de fóruns, de cadeias.

[...] Mas de qualquer maneira, construía, fiscalizava e implantava. Até que isso vai perdendo a intenção inicial, vai ficando uma coisa burocrática, fica fechado, porque criaram a CPOS como uma contrapartida mais ágil, menos complicada em termo de legislação e licitação.

Mas a gente não consegue entender que em termo de qualidade, postura profissional, não acrescentou nada. Assim como o DOP morreu. [...]

A FAU por exemplo. Eu tive a sorte de que quando eu entrei na FAU, na primeira, segunda turma, participei da implantação da FAU... Mas que daqui a pouco começa ficar burocrata, e a FAU acaba sendo »aquele monstro bonito« que está lá. Aquele monstro bonito, de asas, mas é um monstro! Um anjo da guarda, mas um monstro. [...]

Eu falei isso, porque, o quê seria a experiência hoje do DOP, ela é uma coisa que está se perdendo, eu não sei quem está cuidando desse acervo. Os caras que trabalhavam lá , não sei, alguma parte até morreu, alguns vivos, ou alguns tenham atitudes rancorosas com o DOP, porque acabou, sei lá!

A biblioteca eu já declarei aqui que foi descartada, foi doada para a FAU. E a FAU falou: »Essa me interessa, essa não me interessa«. E ofereceu para todo mundo. Não teve respeito algum por esse patrimônio. Essa coisa que me irrita, pois a FAU não teve respeito por esse patrimônio. Como até hoje por exemplo a FAU acha que os caras que trabalham em obra pública são uns »merdas«. [...]

Existe um país fora do nosso contexto! Dos nossos 
pensamentos, das nossas ideias. Um pais real?

\section{Anália}

Se a gente mapeia o acervo possível do DOP, o que a gente pode subtrair daqui, que faz a interface contigo? Porque a história nossa é através de você. A gente gostaria abrir caminhos e entender um pouco desse São Paulo real, dessa arquitetura real e desse Brasil real. Se a gente achasse esse acervo, nosso olhar nesse acervo, seria para que lugar?

\section{Vespaziano}

Talvez a palavra certa seja, a atitude nossa, de universitários, ou de responsáveis pelo aspecto da vida cultural do país. Nossa atitude não vale nada. Como se existia uma realidade altamente controlada da nossa parte, que é »substitiva«, não existe esta realidade. Muito chocante! [...]

Então, como o DOP sempre foi encarado? Agora eu me posiciono, sempre foi encarado como um subemprego [...] eu eduquei meus filhos, criei minha família, construí a minha casa como funcionário publico. Eu tive a oportunidade de vivenciar coisas muito significativas: Acompanhar obra, verificar projetos, eu conheci a cidade e escolhi terrenos [...]

Entre aspas, pouco vivi no DOP, porque eu realmente consegui me comissionar em outros órgãos como o Fundo Estadual de Construções Escolares (FECE), Companhia Estadual de Casas Populares (CECAP), e Companhia Energética de São Paulo (CESP).

E por fim, quando fecharam o DOP eu escolhi uma autarquia similar, digo, que não tivesse que ter interromper minha careira como funcionário público. Eu fui para o Instituto de Previdência do Estado de São Paulo (IPESP). Então configurou um série de experiências. [...]

O DOP sempre criou uma arquitetura comprometida com a construtora. Bastante mão de obra, quanto mais mão de obras mais dinheiro ganha. $O D O P$ nunca resolveu dispersar com a indústria. Têm duas coisas dispares, a indústria da construção e a indústria do material de construção.

Anália

Porque a construção civil está tão atrasada?

\section{Vespaziano}

O DOP era o órgão que construía para todas as Secretárias do estado: Secretaria de Agricultura, Secretaria de Saúde, etc.. Mas pouco à pouco as Secretarias tornaram-se autônomas em termos de obras. Assim as Secretarias começaram construir as próprias obras. A Secretaria de Segurança sempre foi o DOP que fez as obras. Foi daí que surgiu a ideia de construir as escolas através do Fundo Estadual de Construções Escolares (FECE). Eu postei na época para fazer projetos completos, detalhados, com todos os complementares. Daí o Secretário das Obras Públicas Figueiredo Ferraz (1918-1994), convenceu o Secretário da Educação para não fazer isso Assim entrei em contato com o IAB - Instituto de Arquitetos do Brasil - mas não recebi apoio para o desenvolvimento de projetos completos. Dai eu pedi demissão do FECE e voltei para o DOP.

Eu enfrentei pela primeira vez, sem ser Diretor no FECE, o desenvolvimento dos laboratórios nas escolas públicas. Existia um recurso para a elaboração disso e o meu motivo foi pessoal, pois lembrei de como eu tinha aprendido química e física na escola. 
Quando eu fiz curso no ginásio o professor explicava através de uma vitrine as coisas. Os alunos não tocavam nas coisas - você olhava. Nós não fazíamos absolutamente nada e a minha escola era uma das melhores, as outras escolas nem tinham fisica, nem química. Daí eu comecei equipar as escolas. Na época surgiu o Instituto Brasileira de Estudo de Ciência - IBEC, eu procurei esses caras e a gente começou a desenvolver um memorial descritivo. Elencamos todos os equipamentos, dimensionamos e fizemos o desempenho. Eu uso a palavra “desempenho”, a gente não comprava um laboratório pronto. Porque, um microscópio produzido no Brasil custava 40 vezes mais do que o mesmo produto produzido no Japão. Simplesmente não tinha mercado na época. Conseguimos realizar a concorrência.

E por causa do desempenho eu comecei a montar um estúdio e como funcionário, não tinha um departamento para estudar mobiliários escolares por desempenho. Uma cadeira pode ser de plástico, de madeira, de metal, de palha, de vibra ou de caixa de leite descartável.
Comecei a estudar desempenho, uma pessoa sentada tem uma certa altura. Pode ser empilhada. Estragou? Pode trouçar, parafusar, ou jogar fora!

Como eu era diretor, eu contratei a Majumi e a Luisa Batalha. Que era a mulher do Antônio Batalha. $O$ Material sobre os estudos deveria estar no IAB ou FECE. Mas a Majumi assumiu lá, como ela era romântica, ela resolveu fazer aquele negócio com a oficina de construir. Não entrou nessa linha de desempenho. Começou a fazer pré-fabricada aquelas coisas. Ela entrou por um plano de fazer design. Fazer desenho

Quando eu achava que precisava fazer desenho era de menos. Quem faria os desenhos era a firma tal. Eu no meio da licitação, atendendo o desenho padrão ... que é uma coisa que acontece na construção.

Não sei se isso ainda existe, mas eu me lembro que no DOP a gente - isso é um assunto que faz parte da questão da material da construção. Que toda vez que a gente especificava no DOP, se especificava um produto ... Não tinha desempenho [...] Primeira tipo
DECA ou similar, é claro que era sempre colocado similar - porque? Não tinha desempenho, ou similar se a gente quisesse com desempenhos similares mas qual é o desempenho da DECA, eu também não podia segurar, eu tinha que ter um padrão de desempenho. Desempenho é isso: Abrir 200.000 vezes e fechar 200.000 vezes e dai tem que trocar. A vazão tanto! Se abrisse leque! Não abre não, tem isso...! Até hoje não existe isso. Não sei se na Europa existe isso-existe?

O pessoal da Bauhaus acho que pensava nisso. Desempenho. O Objeto tem que ter um certificado.

\section{Anália}

Agora como você fala da Majumi, você falou que ela era uma romântica, uma arquiteta que trabalhou muito tempo na construção civil e na arquitetura visão pré-moldada - mas ela pensava na questão do desenho - vai por ai!

\section{Vespaziano}

De Fazer um desenho de uma cadeira e ver quanto custa, e toda escola vai ter aquele desenho. Não é que toda escola vai ter cadeira. Com desempenho tal, de- 
senho diferente, desenho do fulano, do desenho Frank O. Gehry. Atender seu desempenho, concorda? Não aquele desenho, aquela coisa horrorosa que existe, $e$ até hoje está por aí. A ideia não é industrializada - ao contrário afunilar! Eu estou discutindo isso porque no mínimo detalhe de um desenho, de uma torneira você afunila, e não amplia, então não há possibilidade de conciliar o que eu estou dizendo. A indústria de material de construção daqui a pouco está chorando, está ganhando dinheiro para chuchu e a profissão de arquiteto? Nós estamos inconfidente com isso.

\section{Anália}

Eu sempre fico pensando muito por isso, fico nublada. Tem uma saída? Em fez de fazer um desenho, você faz um protótipo? Na minha cabeça mais clara quanto vocêfaz o que o Lelé fez ou Jean Prouve fez. Que é pensar - fazer e fazer - pensar e o desenho muito mais vai bater...

Vespa

O que está inerente no trabalho dele, é que há uma industrialização. Eu faço isso, e tem esse processo. Ele tem " $n$ " hipóteses em aberto..

\section{Anália}

Toda a sua experiência tem uma interfase com a pré-fabricação?

\section{Vespaziano}

Não, as construtoras não querem a pré-fabricação.

Parece que hoje a arquitetura voltou para as mãos dos engenheiros novamente. Desenvolver uma obra mais acelerada, admitindo padronizações e estão divulgando até um novo tipo de morar. Tem projetos que podem ser entregue em uma semana, mas não há processo de medição. Porque o processo de medição tem respaldo de alvenaria, respaldo da fundação etc. Então não adianta, porque, não tem como entrar na licitação, pois é proibido, não tem como medir. O próprio processo da medição controla o tipo de produto que esta sendo feito. [...]

Os critérios da medição traduzem o que é possível na obra. Por isso o Ruy Gama tentou transformar o DOP em um órgão efetivo de obra. [...] 


\section{Entrevista. \#3}

\section{Data . 26.05.2014}

\section{Participação .}

Clementina Delfina de Ambrosis

Domingos Teodoro de Azevedo Marques Geraldo Vespaziano Puntoni

Sebastian Freidrich Beck

\section{Vespaziano}

Escutei a verdade que o »Plano de Ação« surgiu porque naquela época houve uma mudança no retorno de impostos? Eu sempre ouvi dizer que no governo federal houve um retorno de impostos e entrou um grande volume de dinheiro no tesouro do estado e isto foi bem aplicado? Como se chama o assessor do governador? Conta esta história!

\section{Domingos}

A história é o seguinte. Na campanha, Plínio Sampaio ficou muito ligado ao Carvalho Pinto. Durante o governo de Carvalho Pinto do estado de São Paulo, Plínio foi indicado para a subchefia na Casa Civil. Em 1959, um ano após a eleição de Carvalho Pinto, Plínio se tornou coordenador do Plano de Ação do Governo, função que ele ocupou até 1962.

[...] A gente já tinha antes disso uma outra fase com Padre Lebret. Um grande economista e religioso católico dominicano francês. Uma das coisas que se falava era "ver, julgar e agir«. Que foi levada como uma especialidade do Padre Lebret. Hoje isso se chama qualidade de vida. O Padre Lebret tinha uma metodologia muito própria que ele criou para medir a qualidade de vida. Não era só economia, tinha várias dimensões que ele tentava medir. Ele levava a gente para fazer uma investigação de campo. Foi tudo antes do Carvalho Pinto. Houve um contrato com o governo do estado de São Paulo.

Havia também no Estado de São Paulo uma Comissão Interestadual da Bacia Paraná - Uruguai. O Pai do Paulo Mendes da Rocha era o Presidente da Comissão, quem mandava nessa coisa era o pai do "Paulinho" (Paulo Mendes da Rocha). Nome do Pai era Paulo Menezes Mendes da Rocha. Ele preparou todos os estudos preliminares para a bacia dos Rios Tietê e Paraná. Todas Usinas foram feitas com a base dos estudos Paulo Menezes Mendes da Rocha que tinha providenciado tudo isso com antecedência. Quando o Carvalho Pinto entrou como Governador, já existia todo esse trabalho sobre o Estado de São 
Paulo. Depois foi feito um trabalho semelhante para o estado Paraná, Santa Catharina e Rio Grande do Sul. Deixou-se Matogrosso e Goiás porque eram estados inacessiveis.

\section{Clementina}

O arquivo do SAGMACS (Sociedade de Análises Gráficas e Mecanográficas Aplicadas aos Complexos Sociais), está na Biblioteca da FAU Maranhão. Como o Domingos já falou da economia e do humanismo, o Padre Lebret dizia, que o desenvolvimento não é econômico, o desenvolvimento precisa ser social, senão, não adianta nada. Ele foi o primeiro que fez uma pesquisa. Como posso calcular o nivel de vida das pessoas? Ele fez isto com gráficos - por causa disso o SAGEMAGS - se chama Análises Gráficas e Mecanográficas. Então ele desenvolveu os desenhos que mostraram o retrato.

\section{Domingos}

Esse movimento estava muito no começo, inclusive na França. O Lebret foi formado como engenheiro náutico e naval.

\section{Clementina}

Nós trabalhamos com Padre Lebret. Paulo Menezes Mendes da Rocha trabalhou na Bacia Paraná-Uruguai. E o contrato que o SAGMACS fez foi com a Comissão Interestadual da Bacia Paraná-Uruguai.

\section{Domingos}

O SAGMACS tinha muitos políticos dentro, tanto mais tarde uns se tornaram governadores. Surgiu um outro movimento católico que se transformou mais tarde para o partido PDC (Partido Democrata Cristão, 1945-1965). Eu estava muito perto dessa turma. De um lado Plínio Sampaio, ligado ao Carvalho Pinto e do outro lado Teófilo Ribeiro de Andrade (19222015) um dos fundadores do PDC.

\section{Clementina}

O Estado estava muito ativo nesta época. Criando muitas coisas. Os técnicos começaram a criar ação. $[\ldots]$

O que faltou era um economista. Quem estava disponível era o Professor Antônio Delfim Netto, só que ele era da direita. De certa maneira esse movimento de economia e humanismo, o pessoal do Padre Lebret, era batizado a Marx. Era um catolicismo da esquerda.

\section{Clementina}

Tinha um livro importante do Padre Lebret chamado "Manual do Militante". Lembrando uma frase dele: „Como se ensina trabalhar? Como você ensina tomar banho? - É somente entrar na banheira”. Ele era muito profundo e muito simples. [...]

\section{Domingos}

Importante para entender o Brasil, é que, nunca ninguém ensinou nada a ninguém. Você só sabia fazendo. Numa fase anterior houve uma Comissão mista Brasil e Estados Unidos. Essa relação facilitou muito a mercadoria depois da Segunda Guerra Mundial. Diogo Adolpho Nunes Gaspar, economista, foi convidado para comandar o Plano de Ação e ele aceitou. Estava organizado assim: Havia dois grupos, os Técnicos - onde nós encaixamos e um grupo que dava a orientação-economistas e professores. Esse pessoal se encontrava uma vez no mês. No fim de cada ano fizemos uma publicação, um balanço do que foi feito e o que falta para fazer. Eu tenho cinco volumes do Pla- 
no de Ação. Deve ter os volumes na FAU Maranhão.

\section{Vespaziano}

Tenho uma informação que havia uma mudança na legislação do governo federal, daquele negócio, retorno de dinheiro de impostos recolhidos. Afluiu um recurso, que eu não sei exatamente. Vocês sabem alguma coisa nesse sentido?

\section{Clementina}

Quando eu fui para o FECE em 1960, o Fundo começava a trabalhar com o salário de educação, um dinheiro que ninguém usava, era um dinheiro morto. Salário de Educação era um dinheiro que as empresas pagaram como imposto para a educação e esse dinheiro ficou guardado. O Plano de Ação resolveu aplicar isto. O nome do primeiro diretor do FECE era Carlos Pasquale (1960 - 1961) no Governo Carvalho Pinto. Quando chegou esse dinheiro ficamos muito feliz, porque, pudemos fazer um plano. $O$ dinheiro entrava mensal, as empresas pagavam. Tinha uma norma, quando você faz um grupo escolar tem que empenhar a verba toda, a gente começou a fazer quatro obras juntos e o dinheiro sempre chegava.
A gente podia fazer rapidamente a obra e licitar. Nós tínhamos certeza de fazer um plano e aplicar.

\section{Domingos}

Eu tinha inveja do pessoal da Educação! Eles tinham uma estatística para tudo. Eles sabiam quantas crianças etc.

\section{Vespaziano}

Eles tiveram uma ousadia. Eles podiam definir o tipo de escola, números de salas e definiram o programa da escola.

\section{Domingos}

No ponto de vista politico precisava fazer escola hospital, posto de saúde e fórum. Então Plínio Sampaio queria fazer negociação. Tinha um planejamento ou seja, onde precisava fazer tal coisa. Os prefeitos chegaram como se fossem uma fonte luminosa. Os prefeitos das cidades queriam convencer Plínio Sampaio a construir tal coisa na sua cidade. Mas o Plínio sabia o que já tinha em tal lugar e ele escolhia através do plano. Foi muito amarrado e muito eficiente. Na época se construía muito, muito mesmo!
A gente tinha um mapa do tamanho dessa sala, de todo o estado de São Paulo, indicando onde estavam as obras. E as obras eram feitas pelo DOP. Daí não sei exatamente quando começou o FECE a fazer os projetos.

\section{Clementina}

No FECE começamos estudar a zona rural. Nos íamos escolher o terreno. O Sílvio Breno e eu escolhemos terrenos e desenvolvemos um projeto que eu sempre achei muito interessante. A antiga escola rural era assim: $1^{\circ}, 2^{\circ}, 3^{\circ}$ ano juntos em uma sala só. Quando a gente foi lá para conhecer, os pequenos sentaram na frente e os mais altos atrás. Daí a gente pensou porque não vamos pôr três lousas nas três paredes da sala. O professor, era um só, dava aula em uma lousa e depois ele foi para a outra, dando assim três aula paralelas. Era um projeto muito simples, mas muito simpático e melhorou muito a situação de ensino nas escola rurais. Nós construímos muitas escolas nas zonas rurais. Isso era uma coisa muito positiva. $[\ldots]$ 
A gente estudava cada escola em cada municipio, tinha tudo um controle. Elaboramos um plano da rede escolar, que definiu os critérios e as prioridades.

\section{Vespaziano}

Havia um recurso para equipar os laboratórios das escolas. Eu fiquei encarregado para preparar o material da licitação. Assim, a gente conseguiu licitar o primeiro laboratório.

\section{Clementina}

Sim, eu me lembro. Foi uma outra coisa muito boa. Você trabalhou muito com a gente.

[...] o FECE começava pela primeira vez a equipar as escolas.

[...] Depois do FECE eu fui para o CEPAM - Centro de Estudos e Pesquisas de Administração Municipal.

Vespaziano

Eu trabalhei na EMURB num projeto de pavimentação na cidade. Um projeto muito bacana, todas as pessoas aderiram. Mas o próprio projeto foi viável porque não tinha onde jogar as águas pluviais. A cidade não comportava um projeto de melhoria. Teve 222 que anular o projeto.

\section{Vespaziano}

Vocês criaram o Plano Básico para o EMURB?

\section{Clementina}

Antes o Governo só podia desapropriar áreas para grupos escolares, e não para renovação urbana.

\section{Domingos}

Nós fomos até o Tribunal Federal e ganhamos 5 a 4. Assim começou a renovação urbana na cidade de São Paulo. De repente podia-se desapropriar terra para uma reforma urbana.

\section{Vespaziano}

No projeto CURA do EMURB conseguimos inclusive desapropriar as áreas por causa disso.

\section{Domingos}

Quem criou a EMURB foi o engenheiro Figueiredo de Ferraz. Ele criou um órgão para poder agir. Não existia isso no Planejamento, assim ele criou um órgão dentro do planejamento para poder agir. Uma obra pública que exige muita ação e diversas participações a EMURB assumiu tudo e fez tudo junto e saiu muito mais barato. Quem teve a ideia disso foi talvez o Lúcio Gregori. Primeiro Presidente da EMURB - Empresa Municipal de Urbanização foi o Roberto Cerqueira César (1917-2003).

Vespaziano

Roberto Cerqueira César foi meu professor na FAU.

\section{Clementina}

A ideia era de que o engenheiro construísse a casa e o arquiteto fizesse as fachadas, assim se fazia engenheiros e arquitetos. Não existia até então uma Faculdade de Arquitetura em São Paulo. Eu entrei já fazendo arquitetura. Mas a faculdade começou na Poli e só depois foi para a FAU Maranhão. Eu fui da primeira turma de arquitetura e me formei em 1952.

\section{Domingos}

Eu fui o primeiro funcionário da EMURB. Não, talvez eu tenha sido o segundo - o primeiro funcionário era um livro

Na segunda gestão eu tomei a iniciativa e me apre- 
sentei para Ernest Robert de Carvalho Mange, diretor-presidente da EMURB, de 1975 a 1979. Daí começamos a fazer os calçadões do Centro [...]

\section{Vespaziano}

Houve um concurso para entrar no DOP e contratou uma serie de novos funcionários. Eles criaram vários grupos e eu fui mandado para o Departamento de Ensino Profissional para ajudar a desenvolver os projetos iniciais. Esse grupo migrou para o FECE, sem pertenciar ao FECE. Depois a gente foi comissionado pelo FECE. Era uma equipe pequena.

\section{Domingos}

A burocracia da administração pública era tão grande, que começou-se criar a figura das autarquias, que era uma coisa um pouco mais separado. Mas com tempo as autarquias ficaram também com uma burocracia grande, que as autarquias também não conseguiram trabalhar. Daí se criou a figura da empresa pública, o primeiro exemplo disso é a EMURB. Ela tinha uma autonomia e foi feita para agir. A EMURB foi separada em duas.
Vespaziano

Eu trabalhei no CURA em Jabaquara, até ser mandado embora pelo Nestor. Eu acho que eu fui mandado embora porque ele queria recontratar para fazer um novo estudo. Eu falei que não, precisamos compatibilizar as obras com as demandas da Secretaria. A única obra que conseguimos resolver foi o viaduto que liga o Jabaquara com o Parque do Estado. Mas até hoje ficou uma situação estranha. Mas eu não tenho nada ver com essa obra, pois eu fui mandado embora. A tese da CURA era que novos empreendimentos na área iram gerar um refluxo de recurso e impostos, que iam cobrir o gasto da Prefeitura. Mas nunca esse feedback foi feito. Quem vai lá hoje percebe que tem uma transformação muito grande na área por razão da CURA.

\section{Clementina}

O seu trabalho vai ser muito útil para o Governo do Estado e do Município. Porque você vai redesenhar a história disso. Nós não sabemos quando o FECE foi construido e porquê. E vai mostrando como o Governo se organiza.

\section{Vespaziano}

Eu me aposentei no IPESP. Quando eles criaram o CPOS, eu já estava com trinta anos de trabalho, eles vieram para conversar comigo para eu pedir a demissão. Eu falei que não. Daí eles falaram para nós escolhermos uma autarquia. Uma grande parte do DOP foi para o DAE (Departamento de Águas e Esgotos). Eu e mais quatro colegas do DOP foram para o IPESP. Foi pela primeira vez que tive um cargo de arquiteto no IPESP. 



\section{Entrevista. \#4}

\section{Data . 15.12.2015}

Participação .

Geraldo Vespaziano Puntoni

Sebastian Friedrich Beck
CECAP - Caixa Estadual de Casas para o Povo Presidente: José Magalhães de Almeida Prado (Zezinho Magalhães)

Assessor: Ruy Gama (Arquiteto, Funcionário Público do DOP)

SISLA: Empresa que fez o levantamento planialtimétrico do terreno.

\section{Sebastian}

Você pode falar um pouco sobre os contratos? Você foi cedido pelo DOP (Departamento de Obras Públicas) para o CECAP?

\section{Vespaziano}

Quem assinou os contratos foi o Fábio Penteado, já que o Paulo Mendes da Rocha e o Vilanova Artigas foram cassados durante a ditadura militar. A participação deles só foi possível porque Fábio Penteado os contratou. Eu não fui contratado, fui deslocado do DOP em 1967, mas eram eles quem pagavam o meu salário. Eu e a Giselda Maria Visconte ganhamos menos do que o desenhista. Não estou desmerecen-

do, nós tínhamos um salário de funcionário público.

Sebastian

Quem costurou toda essa trama?

\section{Vespaziano}

Quem realmente maquinou toda essa trama foi o Ruy Gama, ele era assessor do José Magalhães de Almeida Prado (Zezinho Magalhães) e funcionário público do DOP.

Ruy Gama convenceu Zezinho Magalhães a contratar Vilanova Artigas. Por quê? Porque o Ruy era do Partido Comunista, assim como o Artigas.

O irmão do Zezinho Magalhães era presidente da UJC (União da Juventude Comunista) e provavelmente foi ele quem falou para o Zezinho Magalhães pegar o Ruy Gama como seu assessor. Depois o Ruy começou a maquinar tudo isso. 
A CECAP fazia casas, em Jundiai por exemplo, e locações. O terreno era para ser uma horta, tem até um rio lá. Tinha um morro onde foi projetada a caixa d'água que alimentava todo o conjunto.

Mas o que interessa nesse assunto é o seguinte: $O$ Ruy Gama convenceu o Zezinho Magalhães a contratar o Artigas. Mas como fazer isso? Ele estava sendo cassado, não dava para contratá-lo. Provavelmente foi o Ruy Gama quem falou para contratar o Fábio Penteado [...] eles contrataram o Fábio Penteado e ele terceirizou o projeto para o Paulo Mendes da Rocha e Vilanova Artigas. Fábio Penteado foi quem respondeu pelo contrato. Para poder justificar isso é preciso achar o contrato. Provavelmente o DOPS e a polícia secreta tinham consciência disso, mas o Fábio Penteado contornou isso, ele foi politico. Isso não quer dizer que o Fábio não participou do projeto. Claro, o Fábio Penteado, um ótimo arquiteto, discutiu, participou e trabalhou muito no projeto. Eu era pau mandado. Projetei com o Artigas as escolas, Giselda Visconti fez o hospital, Renato Nunes projetou o estádio e Arnaldo Martino fez todo o dimensionamento do conjunto em pré-moldado. $O$ 226
Fábio Penteado foi responsável pela concepção geral do conjunto. Quem contratou a SISLA? Provavelmente a SISLA também foi contratada pela CECAP.

Você precisa localizar esse contrato e publicá-lo no seu trabalho. Como documento, ele esclarece uma série de coisas. Ficou essa fantasia de que o Artigas era muito bacana, e eles o contrataram. Eles não contrataram o Artigas, mas isso não quer dizer que ele não tenha feito o projeto, ele fez o projeto, mas foi contratado pelo Fábio Penteado. E tudo isso foi uma trama do Ruy Gama. Eu acho que sou a última testemunha que insiste nessa versão.

Falcão Bauer, Alfredo Paesani, José de Lamadri (desenhista) e Arnaldo Martino provavelmente foram contratados pelo Fábio Penteado.

\section{Sebastian}

Em que projeto você trabalhou?

\section{Vespaziano}

Eu trabalhei principalmente nas escolas, por causa da minha experiência no FECE (Fundo Estadual de
Construções Escolares). Arnaldo Martino foi responsável pelo planejamento da pré-fabricação - a tese de mestrado dele foi sobre isso. Tem uma maquete na Escola da Cidade que mostra os prédios habitacionais, e em cima dos pátios tinha um pergolado que não foi construido, na maquete tem esse sombreamento.

\section{Sebastian}

Você pode falar um pouco sobre os equipamentos domésticos? Por que essa ideia não foi adiante?

\section{Vespaziano}

Havia a intenção de colocar equipamentos domésticos em todos os apartamentos. O pai do Fábio Penteado tinha uma companhia de equipamentos domésticos. Alguém contratou a mulher do Paesani, Eugênia Paesani, para fazer um estudo sobre esses equipamentos, mas a conclusão da pesquisa deixou claro que as pessoas que compraram um apartamento no CECAP já tinham todo o equipamento necessário, então resolveram cancelar o planejamento desses equipamentos domésticos. Só ficou a privada e o chuveiro, nada de armário. 
As escolas planejadas não tinham nada de pré-fabricado. A ideia do pré-fabricado foi levada adiante somente nos prédios habitacionais. Fábio Penteado tentou convencer a construtora Camargo Corrêa a fazer a obra usando pré-fabricados. Tudo foi desenhado e desenvolvido pelo Arnaldo Martino. O projeto tinha tudo para ser inovador.

\section{Sebastian}

Mas por que a construtora não topou fazer a pré-fabricação?

\section{Vespaziano}

Quem defendeu a ideia da caixa d'água única foi o Paesani. Ela seria colocada no lugar mais alto do terreno, e alimentaria todos os prédios. No final, não fizeram a caixa d'água única, cada prédio ficou com a sua própria caixa. A cidade de São Paulo recebe água de duas represas, e cada um de nós tem 2000 mil litros de água guardados em casa. É muito mais caro e muito mais anti-higiênico. E se você quer limpar a caixa d'água você joga fora dois mil litros. Quem tem o direito de guardar dois mil litros de água em casa, enquanto muita gente não tem água?
O CECAP não foi feito em pré-fabricação porque a pré-fabricação reduz a mão de obra necessária durante a obra. No Brasil, a mão de obra não é nada industrializada. Se você faz uma pesquisa na indústria do material de construção, vai descobrir que ela é responsável por $7 \%$ do produto bruto nacional e não tem nada a ver com a construção brasileira. Infelizmente a construção brasileira compra seu material na indústria do material de construção. Esses $7 \%$ são resultado de compras em mutirão, como o cara que pinta a sua casa, a pessoa que compra um saco de cimento, etc. Não existe uma "indústria da construção”, existe construção. Não existem materiais de construção produzidos em função da indústria da construção. Se você vai num depósito de materiais de construção, você compra pregos, areia, cimento ou tijolos - mas você não compra uma estrutura pronta. O que vale é a quantidade de pessoas trabalhando na obra e a construtora não quer repartir isso com a indústria. Quando uma obra começa a ser industrializada, ou seja, ficar mais eficiente, a construtora acaba ganhando menos, por isso a Camargo Corrêa não topou. Eu não frequentei a obra, pois já estava na CESP.
Sebastian

Quem faz a costura entre todos os órgãos públicos?

\section{Vespaziano}

Quem faz essa costura é o DOP. Eu sempre fui cedido ou comissionado para outro órgãos. Já fui cedido do DOP para trabalhar no CECAP e comissionado para trabalhar no FECE e CESP. Nunca deixei de ser funcionário público e me aposentei no serviço público.

\section{Sebastian}

Qual é a imagem do arquiteto?

\section{Vespaziano}

A imagem do arquiteto não existe. Ele deve estar preparado para enfrentar desde a urbanização, que foi meu caso na EMURB, até a construção de escolas e residências populares ou um projeto de matadouro ou presídio. Não sei se posso dizer isso, mas o arquiteto deve estar apto a enfrentar as questões relativas ao abrigo das atividades humanas.

Sebastian

A pré-fabricação foi um assunto central durante a 
sua atuação como arquiteto e funcionário público?

\section{Vespaziano}

A pré-fabricação nunca foi uma questão central do meu trabalho. A pré-fabricação surgiu no FECE quando eu tentei estabelecer critérios de desempenho para o mobiliário escolar. Hoje no FDE os arquitetos são obrigados a usar um manual com detalhes e dimensões. Na realidade, nós deveríamos estabelecer as prioridades a serem cumpridas. A sala deve ser ventilada, ter uma boa orientação e luminosidade. Não deveria existir um desenho prévio. Eu sempre achei que a norma e a estandardização levassem à industrialização. As construtoras e as empreiteiras realizam um procedimen-

to que leva para esse tipo de ação e a culpa é do governo. O governo sempre retrata o poder, mas o que é o poder? É o capital. O Brasil não é um país que está infenso isso - pelo contrário. Os dispositivos democráticos são muito frágeis no Brasil. 
Data . 04.07.2016

Participação .

Marlene Picarelli

Lúcio Grinover

Geraldo Vespaziano Puntoni

Sebastian Friedrich Beck

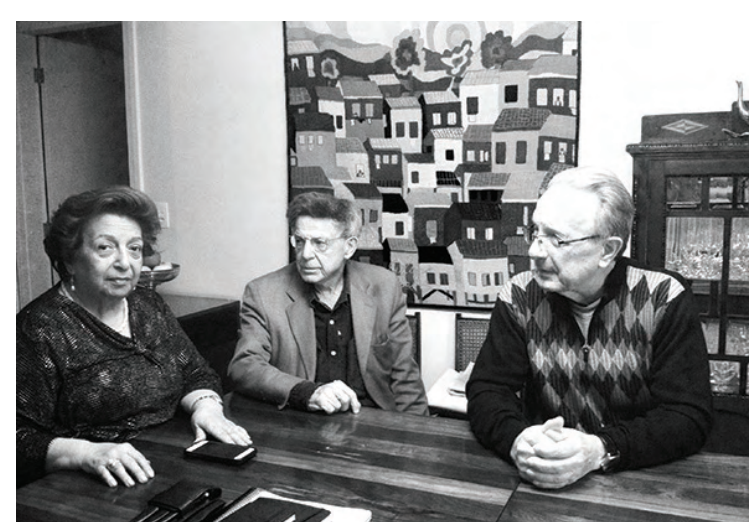

IMAGEM 154. Marlene Picarelli, Geraldo Vespaziano Puntoni, Lúcio Grinover, durante a entrevista, Fonte: Sebastian F. Beck, 04.07.2016

\section{Marlene}

Quando eu entrei no DOP, eles mandavam a gente fazer a fachada da frente sem pensar no projeto como um todo. Conversando com Jorge Salomão, ele falou que ele está com uma vontade de reformular as normas. A norma dizia: pegar o projeto que já existia e implantar no lugar. As normas existentes limitaram uma atuação maior dos arquitetos do DOP, dai Jorge Salamão sugeriu uma reformulação das normas. As normas diziam para pegar somente os projetos existentes. Assim foi formado uma equipe composto por mim, Jorge Salamão, Arnaldo Tonissio e Irene Schneck (Engenheira) para reformular as normas. Quando esse trabalho estava quase finalizado, passou Lúcio Grinover e levou a gente para o Departamento do Ensino Professional, para desenvolver projetos de escolas profissionais, ainda não tinha nada a ver com o FECE. Eu, Vespaziano, Sílvio e Tonissio.

Eu e Lúcio (Grinover) entramos na FAUUSP em 1953, e nos formamos em 1957, depois eu arrumei um estagio no escritório do Vilanova Artigas. Artigas e Cascaldi tinham projetos, mas não pagavam nada. Como eu não ganhava nada, o próprio Artigas falava para mim, que o Governo tinha aberto vagas no DOP, e recomendou que eu prestasse a prova para entrar.

Na entrevista da prova eu falei com Faria Lima, Secretario de Obras, eu passei a prova e entrei no DOP em 1960. Em 1961 já começou o trabalho sobre as Escolas Industriais, que era uma equipe construida pelos arquitetos Lucio Grinover, Roberto José Goulart Tibau, Hélio de Queiroz Duarte. Em 1962 eu e Vespaziano mudamos para o FECE. 1963 a 1964 eu fui para Veneza. O primeiro chefe do FECE foi Carlos Pasquale, composto por Flávio Villaça, Clementina Ambrósio, Sabatina Gervacio, Celso Biasio e Mario Guarneri.

Quando eu voltei de Veneza, o governo Carvalho Pinto tinha caído e Ademar de Barros tomou o seu lugar, em consequência disso eu saí do FECE. Atra- 
vés do Hélio Duarte eu comecei a dar aula e entrei no escritório dele. Depois eu saí do escritório do Hélio por causa de alguns problemas pessoais e montei um escritório com Silvio (Breno) na Rua Dona Veridiana e fiquei dando aula na FAU.

\section{Sebastian}

Como surgiram as Escolas Industriais? Foram construídas as escolas e depois o estado não tinha condições para fazer as manutenções, daí passou para o SENAI?

\section{Lúcio}

É que o governo queria construir escolas industriais, quem estava fazendo escolas industriais era o SENAI. Então eles resolveram trabalhar juntos. Eu era Chefe de Obra do SENAI, dai eu fui desenvolver um plano de escolas, através do SENAI.

Luiz Gonzaga era do SENAI, organizava parte de ensino e organizava as oficinas e a distribuição. Eu acho a primeira escola industrial era do Brás. Tinha uma Escola Normal do SENAI e tinha uma Escola Técnica do SENAI. Foi um edifício só para a Escola Técnica.

\section{Sebastian}

Por quê o Estado resolveu entrar?

\section{Lúcio}

Não sei. Dever ter sido um problema de caráter político.

\section{Vespaziano}

O FECE surgiu porque tinha recursos disponíveis.

\section{Marlene}

No Governo Carvalho Pinto o negócio se inverteu. Antes era assim: Os deputados e prefeitos vinham do interior e pediam uma escola nova e o Governo fazia, independente para o que era aquela escola. Quando começou o Governo Carvalho Pinto, isso se inverteu: A gente planejava - não adiantava o deputado pedir uma escola. Só se aquela cidade precisasse de uma escola ele mandava construir.

\section{Vespaziano}

Nós planejamos, eu me lembro inclusive que havia um recurso no FECE para equipamentos de laboratório...

\section{Marlene}

Construímos sete escolas aqui na capital. Você se lembra da viagem que fizemos para o interior de São Paulo, para ver como as escolas estavam? Se podia transformar as escolas se quisessem ou não.

Vespaziano

Começou também a história da Escola Vocacional.

\section{Marlene}

As Escolas Vocacionais eram uma ideia ótima!

\section{Vespaziano}

Eu fiz a adaptação de Batatais (Planta existente).

Eu pedi a demissão no FECE. Foi durante o Governo Adhemar de Barros. Eu consegui na época, que o FECE tirasse as obras das escolas do DOP e passasse para o FECE. Mas nesse contexto eu tinha definido no FECE que a gente só fazia obra e licitação de obra com projeto completo. E quando eu fui ver, não era mais do que um projeto básico. Dai eu fui falar no IAB, mas eles defenderam isso, pois eles pegaram arquitetos de fora. Daí eu falei “Tchau”! 
[...] Eu gostava muito do Ernest Robert de Carvalho Mange, só não gostei de ir no escritório dele. Escritório climatizado a $10 \mathrm{C}^{\circ}$ !

O que eu acho muito importante são essas coisas de normas.

Marlene

Tinha uma autorização para fazer as reformulações das normas, sim. Quando a gente fez uma reunião com eles, explicando que não dava mais para continuar daquele jeito, de todas as obras iguais, eles autorizaram para que a gente fizesse esse estudo. A equipe fez um trabalho muito legal. A gente nem tomava conhecimento de onde ia ser, que terreno ia ser construído. A gente só recebia a ordem de fazer a fachada da frente. Foi terrivel, não dava para aguentar! Tinha coisas estabelecidas, os desenhos estavam prontos. Tinha um arquivo, e os desenhos. Você pegava lá fachada principal e você estudava se ela se adaptava naquele lugar. Era uma locação de fachadas! Não tinha locação de prédios.

Com esse estudo a gente começou a questionar, onde iria construir, precisava saber o terreno, que carate- rística tinha que ter o terreno. Que necessidade essa cidade tinha, quantas salas de aula a cidade precisava, o que faltava?

\section{Vespaziano}

O local das escolas era geralmente em praça públi-

ca. O FECE foi o primeiro que estudou locação de escolas. São Paulo está cheio disso, na Praça da República, Praça Buenos Aires, Jardim da Luz. Você vê que todas as praças tem.

Esse planejamento do FECE foi ótimo, pela primeira vez que se fez isso, por isso estamos discutindo esse assunto.

\section{Vespaziano}

Os projetos eram feitos pelo escritório do Mange e Engerix. O escritório não conseguia acompanhar e a obra tinha pressa. Falaram que tinham um erro de locação de um quilômetro.

Tinha um problema muito sério na escape da água. A obra andava na frente do projeto. Tinha um escritório técnico com calculistas lá. Ricardo Chahin, Enzo
Grinover e outros trabalhavam em obra mas também em projeto ao mesmo tempo. Eles andavam fazendo casas pré-moldadas em madeira. Montaram as divisórias no chão e levantaram. Eu nunca vi uma coisa parecida como obra, era impressionante!

\section{Vespaziano}

A reforma do Martinelli foi muito interessante. A grande peça da reforma é o projeto jurídico, o edificio era propriedade de deus e de todo mundo. $O$ advogado Sampaio Mesquita, conseguiu o projeto jurídico para poder demolir as divisórias e os apartamentos antigos.

\section{Vespaziano}

Quando eu voltei para o DOP, a minha chefe era Teresa Katinsky, na Diretoria de Obras Especiais. Nós cuidamos da fiscalização das obras de restauro que o Condephaat fazia. Eu fiscalizava a obra do Solar do Valim, do Manuel de Aguiar Valim, ele fez a linha de ferro, e construiu uma estação metálica importada em Bananal. Essa estação foi desmontada e montada errada. De tal jeito, que as lâminas, em forma de " $L ”$, que levavam a água para fora da estação, eles 
montaram errado e o " $L$ ” jogava a água para dentro da estação. Um detalhe pequeninho!

No Solar do Valim fizeram a prospecção mal feita, pois havia uma estrutura no meio que eles esqueceram. Tiveram que fazer colunas de eucalipto, então ficou uma redoma. Não sei se eles conseguiram resolver. Em baixo era taipa de pilão e em cima pau a pique com adobe, então não dava para jogar toda carga em cima.

\section{Lucio Grinover}

Carlos Paquale era um cara legal, eu me dava bem com ele. Eu me reportava diretamente a ele. Eu era o SENAI e ele o Diretor do FECE. Eram bons tempos, a gente fazia coisas fantásticas.

\section{Vespaziano}

Foi a primeira vez que se planejou a distribuição de escolas. Planejamos programas de escolas, número de sala e tudo tinha uma relação. Clementina tinha um plano de distribuição das escolas, ela tinha um certo controle

O que não estava muito assentada era a participação 232 do Departamento de Ensino Profissional. Vocês (Lucio Grinover) foram então cedidos pelo SENAI para fazer esse Plano.

\section{Lucio}

Sim, a gente foi emprestado do SENAI para fazer este plano. O que é importante. Todas as informações para você decidir onde, como e quando colocar uma escola industrial. O SENAI que tinha as informações, nós tínhamos todas as informações.

\section{Marlene}

As construções das Escolas Industriais estavam de acordo com o desenvolvimento da indústria no Brasil. Porque era a época que se dizia, precisamos de mão de obra especializada, e não tinha. Então vamos fazer Escolas Industriais. Daí começou uma discussão de um lado que queria construir escolas vocacionais e os outros escolas industriais.

\section{Sebastian}

Voltando para as normas, qual foi o produto final?

\section{Marlene}

O resultado foi um caderno de normas, os cadernos de encargo do DOP. Quando eu saí, estava sendo elaborado. Depois eles foram publicados pelo DOP.

\section{Sebastian}

O arquivo do DOP ficou em parte, descartado.

\section{Vespaziano}

O CPOS tem uma parte. Mas seria interessante o arquivo escrito, tinham os memoriais, os projetos e suas respetivas pastas. Tem tudo um procedimento.

Marlene

O DOP tinha feito todo levantamento dos sistemas construtivos que se usa no Brasil e no exterior. Estava tudo documentado. Onde foi parar tudo isso? Ninguém sabe!

\section{Lucio}

Isso é uma coisa que me entristeceu e continua me entristecendo. Se você é um sujeito que não faz parte de um determinado grupo, e esse grupo tem poder, você está excluído. Na maneira mais dramática. 
Onde foi parar esse trabalho? É um trabalho de levantamento, não é um trabalho ideológico.

\section{Marlene}

A gente estava querendo encaminhar o material para a biblioteca, e não conseguimos.

Lucio

Perder esse material é uma pêna. Mas tem gente que perde essas coisas!

\section{Vespaziano}

Eu estava dando aula na FAU, e a maquete saiu de lá, direto do subsolo. Eu dava aula de desenho, quando cheguei na minha sala, estava lá um canto cheio de livros. Olhei, fui lá, e peguei um livro. Sabe o que era? A biblioteca do DOP.

Estava lá jogados, e qualquer aluno podia pegar. Eu fui para falar com a biblioteca, daí eles falaram que é tudo descartado! A biblioteca do DOP era um arquivo cultural. A biblioteca do DOP era um arquivo para ser inteiramente preservado. Foi descartado! A biblioteca do DOP era uma obra prima.

\section{Lucio}

Porque tem essa mentalidade de destruir aquilo que pode fazer parte da memória. Se você escolhe a memória em função das suas ideologias e seus interesses, aí realmente, você joga fora quase tudo.

Vespaziano

Quando você recebe uma biblioteca, a condição é que seja preservado tudo. Não pode desmontar.

O SENAI foi convocado por causa da experiência que ele acumulava. Eram os dados que ele tinha. Porque o Estado resolveu entrar nessa coisa? Depois das obras concluídas, voltaram para o SENAI. Eu participei da reforma dos prédios que foram depredados. O único prédio da Escola Industrial que ficou intacto foi ali perto do Corinthians, perto do parque São Jorge, um bairro de portugueses. Eles tomaram conta da obra e do prédio.

\section{Sebastian}

Mas por quê a escola foi construída e ficou sem uso?

\section{Vespaziano}

Tinham escolas que a construtora terminou em cinco, seis semanas, dai tiraram os guardas. Tem escolas que roubaram as pias, torneiras etc.. Daí, doaram as escolas para o SENAI.

Lucio

O que a gente fazia era a partir da determinada cidade. Construímos escolas em função daquilo que a cidade produzia.

Eu entrei no SENAI em 1959 



\section{Entrevista. \#6}

\section{Data . 14.07.2016}

Participação .

Maria Giselda Visconte

Geraldo Vespaziano Puntoni

Sebastian Freidrich Beck

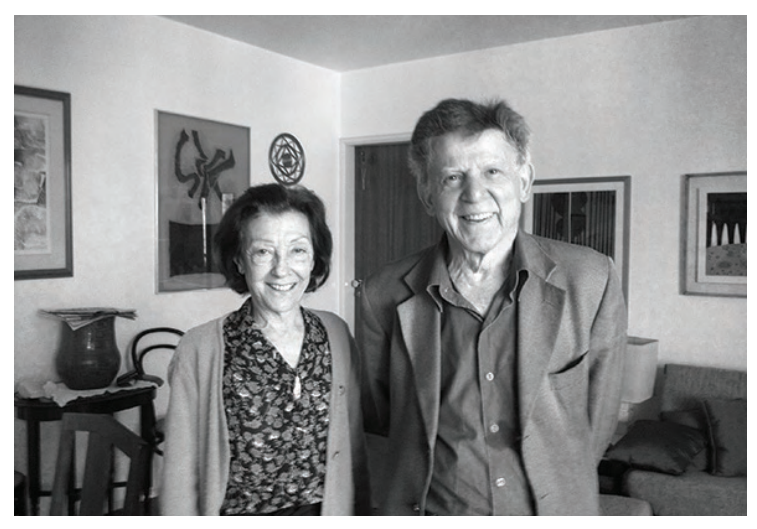

IMAGEM 155. Maria Giselda Visconte, Geraldo Vespaziano Puntoni, durante a entrevista, Fonte: Sebastian F. Beck, 14.07.2016
Maria Giselda Visconte se formou na FAU USP juntamente com Geraldo Vespaziano Puntoni na quinta turma da FAU USP.

\section{Giselda}

Eu comecei a trabalhar no DOP, depois eu fui para a CECAP e em seguida eu comecei a dar aula na FAAP. Comecei montar o curso de arquitetura na FAAP. Eu montei todas as ementas do curso e montei o currículo.

Vespaziano

Mas isso foi em uma segunda grade. Ocursojá existia.

Giselda

Eu cheguei lá e eu fiquei como coordenadora do curso.

\section{Vespaziano}

A grande proposta da Giselda era criar a faculdade de arquitetura da FAAP. E isso não saiu do papel, porque já existia a Faculdade de Artes Plásticas no qual estava inserido o curso de arquitetura. Eu já dava aula lá e convidei a Giselda para dar aula lá. Depois ela virou coordenadora e estabeleceu uma nova grade curricular. Na FAAP hoje tem três grades.

Uma coisa você precisa me dizer. Fizemos o mesmo concurso para entrar no DOP?

\section{Giselda}

Sim, fizemos o mesmo concurso.

Você me ligou para fazer o concurso.

Eu trabalhava num escritório, eu acho que eu trabalhava na época com Fábio Penteado. Eu acho que dava aula também nessa época. Fazer projeto mesmo, pela primeira vez, foi no DOP. Nos primeiros três meses fizemos orçamentos, isso obrigava a gente ler plantas, medir e fazer cubagem.

Eram muitas escolas, então eles iam procurar terrenos para fazer escolas no estado de São Paulo. Não era somente escolas, também cadeia, delegacia, pos- 
to de saúde. Fizemos orçamentos, pois tinha que fazer concorrência pública, pois era uma obra pública. Tinha que fazer cubagem. Ou seja, orçar para o governo saber o preço para poder construir. Daí tinha também toda a equipe de engenheiros que cuidava também das obras. Nós éramos da equipe de fazer projetos, a gente acompanhava também as obras. Era um sistema muito grande.

\section{Sebastian}

Vocês tinham uma liberdade para projetar?

\section{Vespaziano}

Não havia muita liberdade. Porque dois terços do que se projetava, era locação, ou seja você pegava um projeto já existente...

\section{Gisleda}

... Existente, que nós tínhamos feito. Eles repetiam, os projetos eram repetitivos. O Fórum é um exemplo, o Estado está cheio de Fóruns iguais. Nós fizemos um e depois eles implantavam igual. Se chamava projeto padrão. Quando tinha um terreno muito diferente a gente fazia projeto especial.

\section{Vespaziano}

A primeira ação modificando essa atitude foi o intermédio do IPESP. O IPESP começou contratar projetos de arquitetos para elaborar projetos. Quem fazia a obra era o DOP, o IPESP pagava os projetos, contratava Artigas e Paulo Mendes da Rocha.

\section{Giselda}

Fazer obra significa orçar e licitar. Para fazer orçamento precisava de todos os detalhes dos projetos, se não, não dava para fazer orçamentos. A gente trabalhava muito.

\section{Vespaziano}

A equipe do DOP não dava conta da vontade do Governo durante o PAGE. Tinha o FECE, um fundo que recolhia dinheiro das empresa para construir escolas, a participação das empresas no plano estadual educacional. Então tinha dinheiro e o Fundo (FECE) começou fazer projetos. Mas quem construía era o DOP. Nessa iniciativa o IPESP tinha muito dinheiro, na verdade, um dinheiro que não podia ser aplicado nisso, até hoje o estado tem uma divida com o nosso Fundo de Pensão. O mecanismo é mais doidão do que se possa imaginar.

\section{Giselda}

Eles construíram mesmo. Hoje toda cidade do interior tem ginásio, colégio. .. A gente viajava muito, tinha carros para nos levar para as cidade do interior para fiscalizar e acompanhar as obras. Foi muita responsabilidade para jovens arquitetos, tínhamos acabado de sair da faculdade. Nós conhecemos o interior de São Paulo inteiro. Tinha cidades no interior de São Paulo que demorava mais de dez horas para chegar. Ficamos pelo menos um dia na cidade e no dia seguinte voltávamos.

\section{Vespaziano}

Eu trabalhei numa época (1981 - 1988) na Diretoria de Obras Especiais (dentro do DOP). A irmã do Júlio Katinski era a minha diretora (Teresa Katinski). Essa diretoria era encarregada das obras de restauro e fiscalizava. Elaborava projetos especiais como por exemplo de creches. Tinha por exemplo a Secretaria de Viação perto da Marginal Tiete (Edificio do Centro de Convivência Infantil da Secretaria de Transporte do Estado de São Paulo, Avenida 
do Estado, Brás, 1981). Eu fiz o projeto da creche. Não existia uma creche, não existia um padrão de creche. Eu fiz uma creche na cobertura de um prédio (Obra de reforma da cobertura e do subsolo do Edifício do Tribunal da Justiça Militar, Rua Vilanova, $N^{\circ} 268$, Vila Buarque, São Paulo, 1988). Como eu já tinha trabalhado no CECAP, quando eu projetei eu usei as ideias do Artigas e projetei um pátio interno. Era bonita a creche. A Secretaria quebrou tudo e fez um estacionamento da Secretaria de Viação. Nem sei se tem hoje ainda uma creche, talvez tenha virado depósito. Mas era uma intenção na época das secretarias, fazer creches para os funcionários. Quem fez os projetos, foi a minha diretoria.

\section{Vespaziano}

O FECE começou a padronizar as coisas. Uma escola é isso, a sala de aula tem esse tamanho, a janela tem que ser assim. Até hoje o FDE tem esses critérios baseados na manutenção do futura. Tudo virou um padrão e começou no FECE. Foram Clementina e o Fábio Villaça que perceberem que tem um potencial de construir, que precisa ser normatizado. Quantidade de classes na escola, quantos alunos por classe, tem cantina ou não, auditório ou não? Assim, começou o padrão de escola. É também um resultado da FAU USP, Fabio Villaça, Clemetina, Lucio e depois a gente...

Eu não projetei presídios, mas cheguei a projetar cadeias.

Vespaziano

A Giselda trabalhou muito tempo também no projeto Zezinho Magalhães Prado-CECAP. Eu estou toda hora afirmando que o contrato do CECAP assinou o Fábio Penteado. Ele assinou o contrato, terceirizando Paulo Mendes da Rocha e Vilanova Artigas. Artigas e Paulo Mendes estavam caçados na época. Eles estavam sem direitos políticos. Eles não podiam contratar.

\section{Giselda}

Sim, o Fábio Penteado não estava nesse rolo, ele era todo amigo. Ele era muito ligado ao Paessani, projetaram juntos, escritório juntos.

\section{Vespaziano}

Você tem o relatório dos equipamentos domésticos que foi desenvolvido pela mulher do Paessani, Eugenia Paesani? Ela fez uma pesquisa, e comprovava, que o pessoal (os futuros moradores da CECAP) teriam já todo esse equipamento. Fogão de oito bocas, geladeira enorme. O que eles fariam com duas geladeiras então? Era um equipamento inútil. O Paessani e a mulher morreram, o Fabio também e o arquivo dele não está acessível. O arquivo dele está com a filha dele. É uma pêna que a gente não pode acessar.

O DOP tinha acabado de virar CPOS (Companhia Paulista de Obras Públicas). Era uma companhia de obras. E nós, que éramos funcionário do DOP, fomos convidados para nos demitir, para ser recontratados pela companhia. Mas todos nós não queríamos pedir demissão, pois em cinco, três anos iríamos nos aposentar.

Giselda

Eu optei por uma outra autarquia que chamava DAE (Departamento de Águas e Esgoto), o Vespa optou pela IPESP. A maioria optou pelo DAE, que na verdade não tinha nada a ver com a nossa profissão. Foi para completar tempo. 


\section{Sebastian}

Para completar a história do CECAP, você pediu demissão no DOP quando começou o seu trabalho no CECAP?

Giselda

Não, eu era comissionada.

Vespaziano

Existia uma figura no Governo Brasileiro que você podia ser comissionado. Você podia passar de uma Secretaria para a outra, recebendo ainda salário da Secretaria anterior. Era o nosso caso. Quem pagava o salário era o DOP. O CECAP e mandava o comprovante da nossa frequência para o DOP.

\section{Sebastian}

Quem chamou vocês para trabalhar no CECAP?

Vespaziano

Foi o Ruy Gama.

\section{Giselda}

Vespa e eu! O Vespa foi e depois me chamou.

\section{Vespaziano}

Chegaram no DOP e perguntaram quem queria trabalhar no CECAP?

Daí, eu falei "eu quero"! Estou disposto.

Eles perguntaram se não havia mais alguém... Eu disse que tinha essa moça..

\section{Giselda}

...Essa boba vai trabalhar muito!

Eu achava interessante. Fazer projeto, eu achava ótimo!

O Fábio eu já conhecia há muitos anos. Ele foi nosso professor. Conhecia ele do IAB. Artigas foi nosso professor.

\section{Vespaziano}

Havia na época um convivo muito grande dos arquitetos entorno do IAB. Final de tarde sempre passávamos no IAB. Era o nosso órgão ideológico. A gente ficava lá discutindo. Infelizmente acabou isso. Assim, todos os arquitetos se conheciam. Mas quem nos levou para o CECAP foi o Ruy Gama. Ruy Gama era o assessor do Zezinho Magalhães Prado.
O desenhista da CECAP ganhava 10 vezes mais do que nós dois. Evidentemente como funcionário público voce tem garantias, aposentadoria. Por isso, quando o Hélio Penteado ligou para a minha mulher, e falou para ela, que ele tinha arranjado um emprego no qual eu ganhasse 10 vezes a mais. Eu não tive como negar o convite para a CESP.

\section{Giselda}

O que interessava pra gente na CECAP era o trabalho, pois era muito interessante.

\section{Vespaziano}

Quando mudamos para o CECAP eu não conseguia mais tomar conta do meu escritório. O nosso contrato não era dedicação exclusiva no DOP. O CECAP deu muito trabalho.

\section{Giselda}

Depois da CECAP eu fui para o IPESP, como assessora do Aldo Rosso. Em seguida eu fui para o Condephaat como Diretora. O órgão que cuidava as obras tombadas. Depois eu voltei para o DOP, porque eu estava comissionada no Condephaat. 
Na CECAP eu acompanhei a obra, participei da implantação, da definição das cores. Materiais da construção, caixilharias. Havia aquele conceito de freguesia, tinha um estádio de futebol, projeto do Renato Nunes. Tinha escolas o centro comercial.

Vespaziano

Eu participei do projeto das escolas. Mas não foram construidas.

\section{Sebastian}

Porque não construíram as pérgolas?

\section{Giselda}

Porque ficava muito caro. Não tinha dinheiro para fazer.

Mas fez parte do projeto e tinha uma intenção, estudos de luz e sombra.

\section{Vespaziano}

No caso do FECE a gente não foi comissionado, a gente foi mandado do DOP para o Departamento de Ensino Profissional. Eu, Silvio, Tonisi, Marlene fomos mandado para o Departamento de Ensino
Profissional para trabalhar com a equipe do Hélio Duarte, que era coordenado pelo Lucio Grinover para fazer as escolas industriais. Foi dai, que eu fui para o FECE, o Carlos Pasquale era presidente do FECE e puxou a equipe para lá. Continuei como funcionário do DOP mas na Secretaria da Educação. Na verdade isso é uma locação de mão de obra. 



\section{[LISTA DE IMAGENS]}

IMAGEM 1. Ficha DOPS, Impressões Digitais, Geraldo Vespaziano Puntoni, 02/04/1979, Fonte: Arquivo Público do Estado São Paulo -10

IMAGEM 2. Desenho Geraldo Vespaziano Puntoni, 1962, Fonte: Arquivo do Sílvio Breno de Souza Santos. -13

IMAGEM 3. Construção da passagem subterrânea (buraco do Adhemar) no cruzamento com Av. São João, tendo a direita o prédio dos correios e praça de mesmo nome, 1950, Fonte: http://netleland.net/ tag/buraco-do-ademar -14

IMAGEM 4. Geraldo Vespaziano Puntoni, Revista Sinopses FAU USP,

1997, Título do desenho: Várzea do Carmo, vendo de lado a Rua General Carneiro -16

IMAGEM 5. Geraldo Vespaziano Puntoni, Revista Sinopses FAU USP 1997, Título do desenho: Largo do Brás, hoje 1997, Igreja Bom Jesus do Brás -16

IMAGEM 6. Geraldo Vespaziano Puntoni, Revista Sinopses FAU USP, 1997, Título do desenho: Largo do Brás em frente da Igreja Bom Jesus do Brás. -16

IMAGEM 7. Geraldo Vespaziano Puntoni, Revista Sinopses FAU USP 1997, Título do desenho: Rua Rubino de Morais, Antiga Rua da Cruz Preta, Esquina com Avenida Celso Garcia, Hoje 1987 -17
IMAGEM 8. Geraldo Vespaziano Puntoni, Revista Sinopses FAU USP,

1997, Título do desenho: Rua Vasco da Gama -17

IMAGEM 9. PUNTONI, Geraldo Vespaziano, Revista Sinopses FAU

USP, 1997, Título do desenho: Sem -17

IMAGEM 10.Foto: Thomaz Farkas, Pessoas passeiam na entrada do

Congresso em 1960, Fonte: http://zonacurva.com.br/brasilia-nao-tem-culpa/ -20

IMAGEM 11. Foto: Ubyrajara Gilioli, Barca utilizada na viagem pelo rio São Francisco, janeiro de 1955. Arquivo de Ubyrajara Gilioli. -21 IMAGEM 12. Desenho Geraldo Vespaziano Puntoni, 1962, Fonte: Arquivo do Sílvio Breno de Souza Santos. -22

IMAGEM 13. Perspectiva, Edifício de Apartamentos, Rua Bahia, Higienópolis, São Paulo, Arquitetos Puntoni e Wojdyslawski. 1962. Fonte: Acrópole. n. 297, v. 25, 1963. p. $266-24$

IMAGEM 14. Esquema Estrutural, Edifício de Apartamentos, Rua Bahia, Higienópolis, São Paulo, Arquitetos Puntoni e Wojdyslawski. 1962. Fonte: Acrópole. n. 297, v. 25, 1963. p. $266-25$ IMAGEM 15. Corte, Edifício de Apartamentos, Rua Bahia, Higienópolis, São Paulo, Arquitetos Puntoni e Wojdyslawski. 1962. Fonte: Acrópole. n. 297, v. 25, 1963. p. $266-25$

IMAGEM 16. Pavimento térreo, Edifício de Apartamentos, Rua
Bahia, Higienópolis, São Paulo, Arquitetos Puntoni e Wojdyslawski. 1962. Fonte: Acrópole. n. 297, v. 25, 1963. p. $266-26$

IMAGEM 17. Pavimento tipo, Edifício de Apartamentos, Rua Bahia, Higienópolis, São Paulo, Arquitetos Puntoni e Wojdyslawski. 1962. Fonte: Acrópole. n. 297, v. 25, 1963. p. 266 -27

IMAGEM 18. Casa Puntoni, fachada para Rua, Fonte: Sebastian F. Beck -28

IMAGEM 19. Casa Puntoni, Escada e garagem, Fonte: Sebastian F. Beck -30

IMAGEM 20. Casa Puntoni, Abrigo de carro, Fonte: Sebastian F. Beck -31

IMAGEM 22.Casa Puntoni, Terraço para rua, Fonte: Sebastian F. Beck -31

IMAGEM 21. Casa Puntoni, Terraço para rua, Fonte: Sebastian F. Beck -31

IMAGEM 23. Casa Puntoni, Sala de estar, Fonte: Sebastian F. Beck -32

IMAGEM 25. Casa Puntoni, Sala de estar, Fonte: Sebastian F. Beck -32

IMAGEM 24. Casa Puntoni, Sala de estar, Fonte: Sebastian F. Beck -32 
IMAGEM 26. Geraldo Vespaziano Puntoni, Escultura, Dodecae-

dro -33

IMAGEM 27. Geraldo Vespaziano Puntoni, Três Esculturas de vita -33

IMAGEM 28. Poesia da Rita Moreira. Achado em uma pasta no arquivo Ślvio Breno, com desenhos do Geraldo Vespaziano Puntoni. -47

IMAGEM 29. EDIFíCIO CAMPOS SALLES, 1928-1930, A NOVA SECRETARIA DA VIAÇÃO, Fonte: Jornal O Estado de São Paulo, Sexta-Feira, 4 de Abril de 1930, Aspecto do prédio alto, rua Riachuelo no. 115 adquirido ante-ontem pelo governo do Estado pela quantia de 8239.6418718, Nesse predio, que foi vendido pelo Sr. Leoncio Corréa de Magalhães, funcionará a Secretaria da Viação -48

IMAGEM 30. ARTIGAS, Vilanova, trabalha no escritório técnico do Departamento de Obras Públicas (DOP). Fonte: http://vilanovaartigas.com/cronologia/periodos/1938 -49

IMAGEM 31. Sequencia de fotos, Caixilho, Ed. Campos Salles, antiga sede do Departamento de Viação e Obras Públicas (DOP), Engenheiros \& Construtores Siciliano e Silva, Rua Riachuelo, 115, São Paulo. Fonte: Sebastian F. Beck -50

IMAGEM 32. Desenhos caixilhos da FAU USP, Fonte: O edifício da FAU- USP de Vilanova Artigas, Antonio Carlos Barossi, p.70, Editora da Cidade, São Paulo, 2016. - -50

IMAGEM 33. Padre Louis-Joseph Lebret apresentando o Plano 242
"Aglomeração Paulistana" em São Paulo. Fonte: Jornal Folha da Manhã, em 05/03/1958 -51

IMAGEM 34. Gráfico comparativo dos níveis de vida entre o nordes-

te a região centro sul e os EUA. Fonte: LEBRET, L.J. Estudo sobre desenvolvimento e implantação de indústrias, 1955. -52

IMAGEM 35. Capa do Livro Plano de Ação do Governo Carvalho

Pinto 1959 - 1963, Fonte: Biblioteca de Direito da USP. -54

IMAGEM 36. PLANO DE AÇÃO DO GOVERNO, distribuição seto-

rial dos investimentos, Fonte: Livro, Govêrno Carvalho Pinto, Plano de Ação 1959-1963, gráfico n5 -55

IMAGEM 37. Tabela, Plano de Ação do Governo Carvalho Pinto. Investimentos em melhoria do homem, infraestrutura e industria, p.11 -57

IMAGEM 38. PENTEADO, Fábio. Fórum de Araras, Ensaios de Arquitetura, Corte e Planta, p. $57-58$

IMAGEM 39. PENTEADO, Fábio. Fórum de Araras, Ensaios de Arqui-

tetura, Perspectiva, p. $57-58$

IMAGEM 40. Fórum Padrão F de Jaboticabal, Fonte: Tese de Doutorado, Maria Tereza Regina Leme de Barros Cordido, USP São Carlos, 2012. -59

IMAGEM 41. Casa Cultural Mazzaropi, Inauguração 1982, Projetado pelo arquiteto Geraldo Vespaziano Puntoni. Fonte: Jornal da Tarde, 05.05.1982-62

IMAGEM 43. CCI, Fachada, Entrada principal, Fonte: Arquivo Pun- toni -63

IMAGEM 44. CCl, Fachada, Entrada principal, Fonte: Sebastian Beck -63

IMAGEM 42. CCI, Pátio na cobertura. Fonte: Sebastian Beck -63 IMAGEM 45. CCl, Espaço Central, Mezanino, Fonte: Sebastian Beck -63

IMAGEM 47. Estação Ferroviária Bananal, 2014, Foto: www.cultura. sp.gov.br/portal/site/SEC -64

IMAGEM 48. Estação Ferroviária Bananal, 2014, Foto: Sebastian Beck -64

IMAGEM 46. Estação Ferroviária Bananal, 2014, Foto: Sebastian Beck -64

IMAGEM 49. Sobrado Valim, Bananal, Pavimento Superior, Planta de levantamento, Prospecções, Demolições, Retiradas, 1987, Fonte: Arquivo Condephaat -65

IMAGEM 50. Sobrado Valim, Bananal, Pavimento Térreo, Planta de levantamento, Prospecções, Demolições, Retiradas, 1987, Fonte: Arquivo Condephaat -65

IMAGEM 51. Sobrado Valim, Bananal, Documento emitido pela Secretaria de Estado da Cultura, Condephaat, 1987, Fonte: Acervo Condephaat -66

IMAGEM 52. Sobrado Valim, Bananal, Detalhe de levantamento, Consolidação da parede de taipa de pilão, 1987, Fonte: Arquivo Condephaat -66 
IMAGEM 53. Sobrado Valim, Bananal, Detalhe de levantamento, Barrotes do Piso, 1987, Fonte: Arquivo Condephaat -66

IMAGEM 54. Desenho Geraldo Vespaziano Puntoni, 1962, Fonte: Ar quivo do Sílvio Breno de Souza Santos. -75

IMAGEM 55. Cronologia da Construção Escolar Paulista. Fonte: http://www.fde.sp.gov.br/PagePublic/Interna -76

IMAGEM 56. Gráfico, Edifícios escolares públicos construídos no Estado de São Paulo. FDE, Arquitetura Escolar Paulista, anos 1950 e 1960. São Paulo: imprensaoficial , 2006. p.16. A produção quantitativa das escolas passa a expressar números significativos justamente em meados do século 20, chegando a seu ápice em meados da década de 1970. Tais indicadores são reflexos do crescimento do país, em particular do Estado de São Paulo. - 77

IMAGEM 57. Planta Térreo, EE Jon Teodoresco em Itanhaém, projeto 1959 de Vilanova Artigas e Carlos Cascaldi. Fonte: http://www. archdaily.com.br/ -80

IMAGEM 58. EE Jon Teodoresco em Itanhaém, projeto 1959 de Vilanova Artigas e Carlos Cascaldi. Fonte: http://vilanovaartigas.com/ cronologia -81

IMAGEM 59. Escola Industrial de Jundiaí, EE Doutor Antenor Soares Gandra, Jundiaí, São Paulo, 1961, Fonte: Google Street View -83 IMAGEM 60.Escola Industrial de Araçatuba, EEPSG Prof. Victor Antonio Trindade, São Paulo, 1961, Fonte: http://mapio net/s/29506820/ -84
IMAGEM 61. Levantamento Escola Industrial de Araçatuba, EEPSG Prof. Victor Antonio Trindade, São Paulo, 1961, Material: Acervo da FDE, São Paulo -85

IMAGEM 62. Levantamento Escola Industrial de Araçatuba, EEPSG Prof. Victor Antonio Trindade, São Paulo, 1961, Material: Acervo da FDE, São Paulo -86

IMAGEM 63. Levantamento Escola Industrial de Jundiaí, EE Doutor Antenor Soares Gandra, Jundiaí, São Paulo, 1961, Material: Acervo da FDE, São Paulo -87

IMAGEM 64. Levantamento Escola Industrial de Jundiaí, EE Doutor Antenor Soares Gandra, Jundiaí, São Paulo, 1961, Material: Acervo da FDE, São Paulo -88

IMAGEM 65. Levantamento Escola Industrial de Jundiaí, EE Doutor Antenor Soares Gandra, Jundiaí, São Paulo, 1961, Material: Acervo da FDE, São Paulo -89

IMAGEM 66. Levantamento Escola Industrial de Jundiaí, EE Doutor Antenor Soares Gandra, Jundiaí, São Paulo, 1961, Material: Acervo da FDE, São Paulo -90

IMAGEM 67. Perspectiva, Escola Técnica Federal de São Paulo, Rua General Júlio M. Salgado, 234, São Paulo, Concurso, 1965, Fonte Arquivo Geraldo Vespaziano Puntoni -92 IMAGEM 68. Planta Térreo, Escola Técnica Federal de São Paulo, Rua General Júlio M. Salgado, 234, São Paulo, Concurso, 1965, Fonte Arquivo Geraldo Vespaziano Puntoni -93
IMAGEM 69. Planta, - 2 Subsolo, Escola Técnica Federal de São Paulo, Rua General Júlio M. Salgado, 234, São Paulo, Concurso, 1965, Fonte: Arquivo Geraldo Vespaziano Puntoni -94

IMAGEM 70. Planta, - $1^{\circ}$ Subsolo, Escola Técnica Federal de São Paulo, Rua General Júlio M. Salgado, 234, São Paulo, Concurso, 1965, Fonte: Arquivo Geraldo Vespaziano Puntoni -95

IMAGEM 71. Planta, $1^{\circ}$. Pavimento/ $2^{\circ}$. Pavimento, Escola Técnica Federal de São Paulo, Rua General Júlio M. Salgado, 234, São Paulo, Concurso, 1965, Fonte: Arquivo Geraldo Vespaziano Puntoni -96 IMAGEM 72.Planta, $3^{\circ}$. Pavimento/ $4^{\circ}$. Pavimento, Escola Técnica Federal de São Paulo, Rua General Júlio M. Salgado, 234, São Paulo, Concurso, 1965, Fonte: Arquivo Geraldo Vespaziano Puntoni -97 IMAGEM 73. Cortes Transversais, Escola Técnica Federal de São Paulo, Rua General Júlio M. Salgado, 234, São Paulo, Concurso, 1965, Fonte: Arquivo Geraldo Vespaziano Puntoni -98

IMAGEM 74. Corte Longitudinal, Escola Técnica Federal de São Paulo, Rua General Júlio M. Salgado, 234, São Paulo, Concurso, 1965, Fonte: Arquivo Geraldo Vespaziano Puntoni -99

IMAGEM 75. Perspectiva, Escola Técnica Federal de São Paulo, Rua General Júlio M. Salgado, 234, São Paulo, Concurso, 1965, Fonte: Arquivo Geraldo Vespaziano Puntoni -100

IMAGEM 76. Prédio do Ginaásio Vocacional »Cândido Portinari« (1962). Fonte: Arquivo do GVCP. -101

IMAGEM 77. Trabalho em Equipe no GVCP. Fonte: Arquivo do 


\section{GVCP -102}

IMAGEM 78. Esquema Escola Rural, Projeto № 943, Fonte: Arquitetura Escolar - FECE, Tema 3 -103

IMAGEM 79. Escola Rural, Richard Neutra em Porto Rico, Fonte: NEUTRA, Richard. „Arquitetura social para países de clima quen-

te« -104

IMAGEM 80. Esquema, Projeto FECE No 856, Fonte: Arquitetura Escolar - FECE, Tema $3-105$

IMAGEM 81. Escuela Vocacional de Tresquerras, 1932, México, Arquiteto Juan O'Gorman, Fonte: Tese de Doutorado, Alexandro Bosquet Navarro -106

IMAGEM 82. Desenho Geraldo Vespaziano Puntoni, 1962, Fonte: Arquivo do Sílvio Breno de Souza Santos. -119

IMAGEM 83. A partir da esquerda: Maria Giselda Visconti, Fabio Penteado e Vilanova Artigas. Inauguração do Parque CECAP, Guarulhos, 1972. Fonte: Fabio Penteado: ensaios de arquitetura. -120 IMAGEM 84. Implantação Parque CECAP, Fonte: Acervo Biblioteca FAU USP $-123$

IMAGEM 87. Maquete, Unidade Habitacional, Parque CECAP, com pergolado, Fonte: Sebastian F. Beck, Maquete Escola da Cidade -124

IMAGEM 85.Parque CECAP, Fotografia da cobertura do prédio, Fonte: Sebastian F. Beck, 15.02.2016 -124
IMAGEM 86.Parque CECAP, Fotografia da área verde entre dois blocos, Fonte: Sebastian F. Beck, 15.02.2016 -124

IMAGEM 88. Parque CECAP Planta Térreo de um Bloco, indicando as áreas verdes, Fonte: Acervo Biblioteca FAU USP $-125$

IMAGEM 89. Parque CECAP, Pavimento Tipo, Paulo Mendes da Ro-

cha, Projetos 1957 - 1999, Cosacnaify, $2006-126$

IMAGEM 90. Parque CECAP, Planta Padrão das unidades de habitação do bloco tipo 1, Fonte: Paulo Mendes da Rocha, Projetos 1957 -1999, Cosacnaify, $2006-126$

IMAGEM 91. Parque CECAP Corte transversal, Paulo Mendes da Ro-

cha, Projetos 1957 - 1999, Cosacnaify, $2006-126$

IMAGEM 92. Equipamentos Domésticos, Fábio Penteado, Ensaios de arquitetura, São Paulo, 1998, p.142. - -127

IMAGEM 94. Parque CECAP, Fotografia Cozinha,

Fonte: Sebastian F. Beck, 15.02.2016 -128

IMAGEM 93. Parque CECAP, Fotografia Sala,

Fonte: Sebastian F. Beck, 15.02.2016 -128

IMAGEM 95.Parque CECAP, Fotografia pela janela da sala, Fonte: Sebastian F. Beck, 15.02.2016-128

IMAGEM 96. Centro Educacional, Pavimento Superior, Fonte: Acropole, abril 1970, №372 -130

IMAGEM 97. Centro Educacional, Pavimento Térreo, Fonte: Acropole, abril 1970, №372 -130
IMAGEM 98. Centro Educacional, Corte A-A parcial, Fonte: Acropole, abril 1970, N³72 -131

IMAGEM 99. Centro Educacional, Corte B-B, Fonte: Acropole, abril $1970, N^{\circ} 372-131$

IMAGEM 100. Fotografia da situação, EE João Solimeo, Vila Brasilân-

dia, Fonte: Google Earth, 2015 -132

IMAGEM 101. Fotografia, EE João Solimeo, Vila Brasilândia, Fonte: Acervo do arquiteto Geraldo Vespaziano Puntoni -132

IMAGEM 102.PLANTA NÍVEL -3.30, EE João Solimeo, Vila Brasilândia, 1969, Fonte: Arquivo FDE -133

IMAGEM 103.PLANTA NÍVEL 0.00, EE João Solimeo, Vila Brasilândia, 1969, Fonte: Arquivo FDE -133

IMAGEM 104. PLANTA NÍVEL 3.30, EE João Solimeo, Vila Brasilândia, 1969, Fonte: Arquivo FDE -134

IMAGEM 105. CORTE LONGITUDINAL, EE João Solimeo, Vila Brasilândia, 1969, Fonte: Arquivo FDE -134

IMAGEM 106. CORTE TRANSVERSAL, EE João Solimeo, Vila Brasilândia, 1969, Fonte: Arquivo FDE -134

IMAGEM 107. Reservatório Elevado. Planta, Corte,Elevação. Fonte: Acropole, abril 1970, №372 -135

IMAGEM 108. Conjunto Habitacional Cecap Guarulhos, São Paulo, 1967, Fonte: http://vilanovaartigas.com/cronologia/projetos/conjunto-habitacional-cecap-guarulhos -136

IMAGEM 109. Desenho Geraldo Vespaziano Puntoni, 1962, Fonte: 
Arquivo do Sílvio Breno de Souza Santos. -145

IMAGEM 110. Mapa Usinas Hidrelétricas, Fon-

te: Arquitetura na CESP, Companhia energética de

São Paulo, Nina Maria Jamra Tsukumo, São Paulo,

1994, p. $89-147$

IMAGEM 111. Relatório Geraldo Vespaziano Puntoni, Aspectos so-

bre a implantação da obra da Usina de Illha Solteira, distribuição dos

trabalhadores em núcleos residenciais construídos nas cidades da

redondeza, aproveitando-se das estruturas urbanas existentes -148 IMAGEM 112. Vila Piloto Jupiá, Três Lagoas, 1965, Fonte: www.dee.

feis.unesp.br/museu -149

IMAGEM 113. Núcleo urbano permanente, Ilha Solteira, Fonte: Arquitetura na CESP, Companhia energética de São Paulo, Nina Maria

Jamra Tsukumo, São Paulo, 1994, p. 102 -150

IMAGEM 114. Idem. p. $103-150$

IMAGEM 115. Estudos de Rodovias - Região UHE Água Vermelha, 1972, Variante de traçado proposto, CESP -151

IMAGEM 116. Estado de Minas Gerais - Região do Pontal, Rede Viá-

ria - Projetos propostos para 1971 a 1975, CESP, 1972 -152

IMAGEM 117. Rede Rodoviária Básica - Região UHE Aguá Vermelha, 1972, CESP -153

IMAGEM 118. Conjunto residencial em Fernandópolis, Região Água Vermelha, Fonte: Arquitetura na CESP, Companhia energética de São Paulo, Nina Maria Jamra Tsukumo, São Paulo, 1994, p. 102 -154
IMAGEM 119. Idem. p. $105-154$

IMAGEM 120. Região Água Vermelha, Casas pré-fabricadas em Indiaporã, Fonte: Arquitetura na CESP, Companhia energética de São Paulo, Nina Maria Jamra Tsukumo, São Paulo, 1994, p. 107 -155 IMAGEM 121. LE CORBUSIER, Fonte: Por uma Arquitetura, Editora Perspectiva, 5E Edição, 1998, p.14 -158

IMAGEM 122. GROPIUS, Walter, Fagus Werk, Alfeld an der Leine, 1911, Fonte: https://de.wikipedia.org/wiki/Fagus-Werk -158 IMAGEM 123. Comissão Geográphica e Geológica 1886 - 1936, Salto de Patos Rio Grande, 1910, Fonte: http://igeologicosp.blogspot. com.br -159

IMAGEM 124. UHE Ilha Solteira, Rio Paraná, 1973, Fonte: http://professormarcianodantas.blogspot.com.br/2015/01/regiao-hidrografica-do-parana.html -160

IMAGEM 125. UHE Ilha Solteira, Casa de força e subestação, Fonte: Arquitetura na CESP, Companhia energética de São Paulo, Nina Maria Jamra Tsukumo, São Paulo, 1994, p. 54 -161

IMAGEM 126. UHE Ilha Solteira, Vertedouro, Fonte: Arquitetura na CESP, Companhia energética de São Paulo, Nina Maria Jamra Tsukumo, São Paulo, 1994, p. 55 -161

IMAGEM 127. Desenho Geraldo Vespaziano Puntoni, 1962, Fonte: Arquivo do Sílvio Breno de Souza Santos. -171 IMAGEM 128. Localização dos projetos de reurbanização da EMURB em relação às linhas Norte-Sul e Leste-Oeste do Metrô. Fonte:
ANELLI, Renato, Plano e conformação da base da metrópole: Redes de mobilidade paulista, 2011, p.41-172

IMAGEM 129. Estudo para o Plano CURA Jabaquara, escritório Croce, Aflalo \& Gasperini, Fonte: ANELLI, Renato, Plano e conformação da base da metrópole: Redes de mobilidade paulista, 2011, p.52 -174

IMAGEM 130. Perspectiva do plano de reurbanisazão da poligonal do Sítio da Ressaca (ao lado do pátio de manobras do Mêtro). A verticalização planejada em conjunto com um parque, restauração da casa histórica de 1712 e construção do Centro Cultural. Fonte: EMURB Revista, Reurbanização -175

IMAGEM 131. Sítio da Ressaca, Centro Cultural Jabaquara a casa histórica em obra, Fonte: EMURB Revista, Reurbanização -176

IMAGEM 132. Centro Cultural Jabaquara em primeiro plano; mais

ao fundo a casa histórica restaurada, Gustavo Neves da Rocha Filho, Fonte: http://www.shieh.com.br/CENTRO-CULTURAL-JABAQUARA -176

IMAGEM 133. Perspectiva Centro histórico São Paulo com o Edifício Martinelli, Fonte: Revista, EMURB -179

IMAGEM 134. Terraço, estado de deterioração antes da intervenção, 1975, Fonte: EMURB, Revista. -180

IMAGEM 135. Apartamento, estado de deterioração antes da intervenção, 1975, Fonte: EMURB, Revista. -180

IMAGEM 136. Andar Típo, andares da intervenção, 
Fonte: Revista, EMURB -181

IMAGEM 137. Andar Típo, após a reforma,

Fonte: Revista, EMURB -181

IMAGEM 138. Fachada Prédio Martinelli, após da reforma, 1977

Fonte: EMURB, Revista. -182

IMAGEM 139. Perspectiva Centro histórico São Paulo com Viaduto

Santa Ifigênia, Fonte: Revista, EMURB -183

IMAGEM 140. Viaduto Santa Ifigênia, Vista superior, 1978,

Fonte: Arquivo, EMURB -184

IMAGEM 141. Viaduto Santa Ifigênia, Detalhe Balaustrada Original

Fonte: Arquivo, EMURB -185

IMAGEM 142. Viaduto Santa Ifigênia, Elevação, Original, 1906. Fon-

te: Arquivo Vivo o Centro, São Paulo. - -186

IMAGEM 143. Rua no Centro Histórico antes da intervenção.

Fonte: Arquivo, EMURB -187

IMAGEM 144. Planta de Situação Centro Novo - Centro Antigo, Ruas

de Pedestres, 1976 - 1978, Fonte: Arquivo, EMURB -188

IMAGEM 146. Rua de Pedestres, Centro Histórico após da intervenção.

Fonte: Arquivo, Viva o Centro -189

IMAGEM 145. Rua de Pedestres, Corte Tipo Infraestrutura. Fonte:

Arquivo, Viva o Centro -189

IMAGEM 147. Rua de Pedestres, Centro Histórico após da intervenção.

Fonte: Arquivo, Viva o Centro -190

IMAGEM 148. Desenho Geraldo Vespaziano Punto- ni, Concurso Nacional, Pavilhão Brasileiro, Expo 70,

Osaka, Japão, Perspectiva Interna, Fonte: Arquivo

$-20$

IMAGEM 150. Ficha DOPS de Geraldo Vespaziano Puntoni, Secretaria da Segurança Pública, Fonte: Arquivo Público do Estado -203 IMAGEM 149. Ficha DOPS de Geraldo Vespaziano Puntoni, Secretaria da Segurança Pública, Fonte: Arquivo Público do Estado -203 IMAGEM 151. Desenho Geraldo Vespaziano Puntoni e Carlos Henrique Heck, Concurso Nacional, Pavilhão Brasileiro, Expo 70, Osaka, Japão, Perspectiva Interna, Fonte: Arquivo Escritório Grupo SP -205 IMAGEM 152. Desenho Geraldo Vespaziano Puntoni e Carlos Henrique Heck, Concurso Nacional, Pavilhão Brasileiro, Expo 70, Osaka, Japão, Planta, Fonte: Arquivo Escritório Grupo SP -206

IMAGEM 153. Desenho Geraldo Vespaziano Puntoni e Carlos Henrique Heck, Concurso Nacional, Pavilhão Brasileiro, Expo 70, Osaka, Japão, Corte e Elevação, Fonte: Arquivo Escritório Grupo SP $-207$

IMAGEM 154. Marlene Picarelli, Geraldo Vespaziano Puntoni, Lúcio Grinover, durante a entrevista, Fonte: Sebastian F. Beck, 04.07.2016-229

IMAGEM 155. Maria Giselda Visconte, Geraldo Vespaziano Puntoni, durante a entrevista, Fonte: Sebastian F. Beck, 14.07.2016 -235 
